1996 Cyprus Gold Exploration drill and geochemical results from the Old Dog Prospect of Treasure Creek of the Fairbanks Mining District, Alaska.

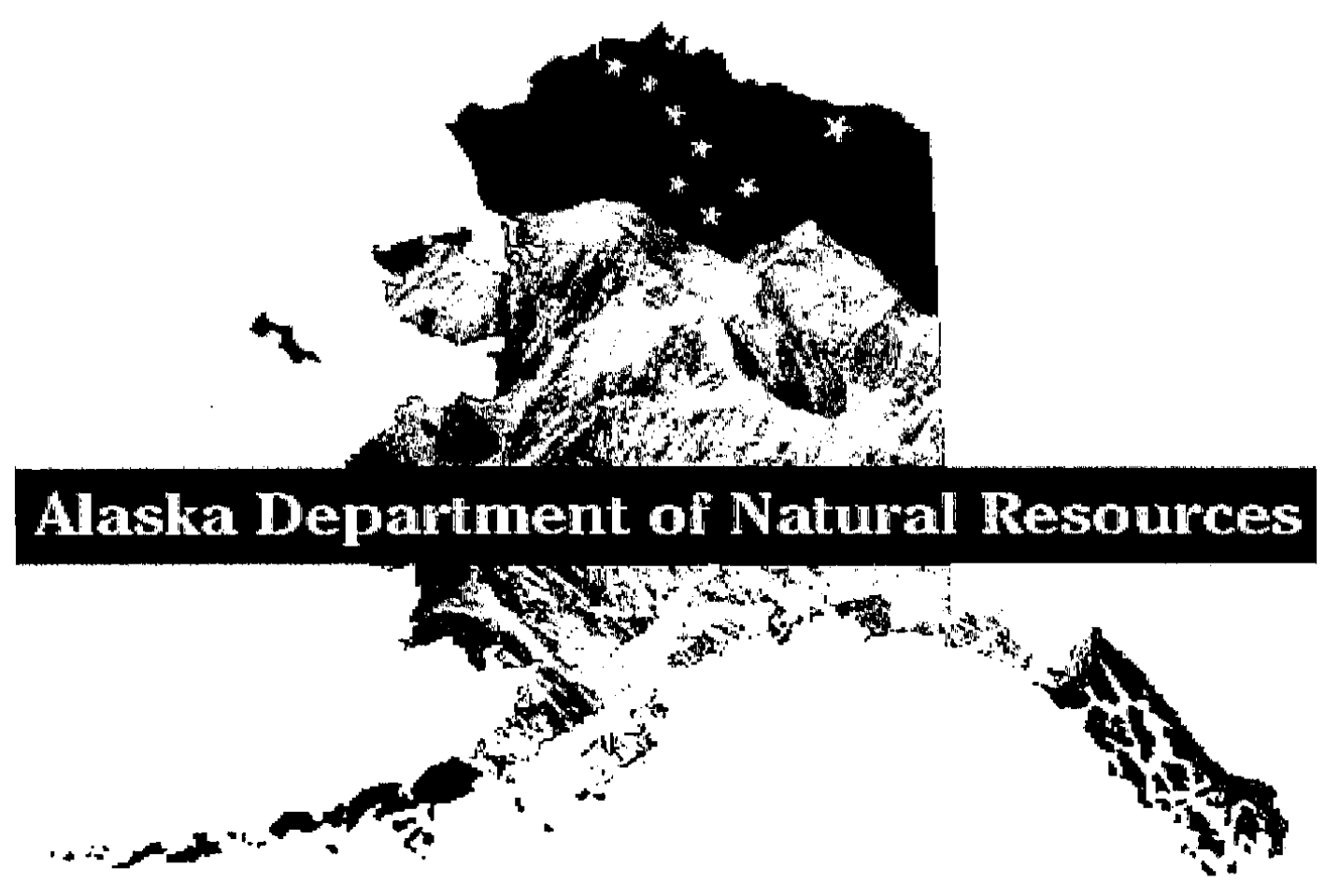

Received 5 November 2002 
TABLE 1

OLD DOG DRILLHOLE SUMMARY

1996

\begin{tabular}{|c|c|c|c|c|c|}
\hline \multirow{2}{*}{$\begin{array}{l}\text { HOLE } \\
\text { (TD) }\end{array}$} & \multirow[t]{2}{*}{ GEOLOGY } & \multirow[t]{2}{*}{ ALTERATION } & \multicolumn{3}{|c|}{ GOLD MINERALIZATION } \\
\hline & & & From-To (ft.) & Interval (ft.) & PpmAu \\
\hline \multirow[t]{2}{*}{$\begin{array}{l}O D-1 \\
\left(225^{\prime}\right)\end{array}$} & $\begin{array}{c}0-140^{\prime} \text { Felsic Intrusive } \\
140-225^{\prime} \text { Quartz }\end{array}$ & \multirow[t]{2}{*}{ 15-45' Bleached } & $110-120^{\prime}$ & 10 & 0.278 \\
\hline & Muscovite Schist & & $145-160^{\prime}$ & 15 & 0.432 \\
\hline \multirow{2}{*}{$\begin{array}{l}\text { OD-2 } \\
\left(210^{\prime}\right)\end{array}$} & $0-95^{\prime}$ Felsic Intrusive & \multirow[t]{2}{*}{$\begin{array}{c}15-40^{\prime} \text { Bleached } \\
0-95^{\prime} \text { Quartz Veins }\end{array}$} & $15-85^{\prime}$ & 70 & 0.213 \\
\hline & $\begin{array}{c}\text { 95-210' Quartz } \\
\text { Muscovite Schist }\end{array}$ & & No & Significant & Values \\
\hline \multirow[t]{2}{*}{$\begin{array}{l}O D-3 \\
\left(85^{\prime}\right)\end{array}$} & $0-55^{\prime}$ Felsic Intrusive & \multirow[t]{2}{*}{$\begin{array}{l}0-55^{\prime} \text { Bleached and } \\
\text { Sericitization }\end{array}$} & $30-55^{\prime}$ & 25 & 0.460 \\
\hline & $\begin{array}{c}\text { 55-85' Quartz } \\
\text { Muscovite Schist }\end{array}$ & & $70-85^{\prime}$ & 15 & 2.123 \\
\hline \multirow[t]{2}{*}{$\begin{array}{l}O D-4 \\
\left(95^{\prime}\right)\end{array}$} & $0-40^{\prime}$ Felsic Intrusive & \multirow[t]{2}{*}{$\begin{array}{l}25-40^{\prime} \text { Bleached } \\
0-40^{\prime} \text { Sericitization }\end{array}$} & & & \\
\hline & $\begin{array}{c}\text { 40-95' Quartz } \\
\text { Muscovite Schist }\end{array}$ & & No & Significant & Values \\
\hline $\begin{array}{l}O D^{\prime}-5 \\
\left(90^{\prime}\right)\end{array}$ & $\begin{array}{l}0-70^{\prime} \text { Felsic Intrusive } \\
70-90^{\prime} \text { No Recovery }\end{array}$ & $\begin{array}{c}15-50^{\prime} \text { Bleached } \\
0-555^{\prime} \text { Quartz Veins }\end{array}$ & $45-60^{\prime}$ & 15 & 0.162 \\
\hline
\end{tabular}


TABLE 2

OLD DOG

DRILL HOLE SUMMARY

1997

\begin{tabular}{|c|c|c|c|c|c|}
\hline HOLE & GEOLOGY & ALTERATION & \multicolumn{3}{|c|}{ GOLD MINERALIZATION } \\
\hline & & & From-To (ft) & Interval (ft.) & $\mathrm{ppm} \mathrm{Au}$ \\
\hline OD-6 & 5-47' QMS/FELSITE & $\mathrm{LIM}, \mathrm{BLCH}$ ? & & & \\
\hline \multirow[t]{4}{*}{$\left(410^{\prime}\right)$} & 47-317' QMS & $\mathrm{LIM} \pm \mathrm{BLCH}$ & $110-115$ & 5 & 0.9 \\
\hline & & & $270-275$ & 5 & 0.31 \\
\hline & 317-374' FELSITE & ARG/SER,BLCH & & & \\
\hline & 374-410' QMS & SPOTTY PYRITE & & & \\
\hline & & & & & \\
\hline OD-7 & 10-112' FELSITE & LIM, ARG, SER & $35-40$ & 5 & 0.5 \\
\hline \multirow[t]{2}{*}{$\left(400^{\prime}\right)$} & & & $75-80$ & 5 & 0.31 \\
\hline & 112-400' QMS & LIM TO 230 & $165-170$ & 5 & 0.37 \\
\hline OD-8 & $0-56^{\prime}$ FELSITE & IIMOVN SFR SUI? & 5055 & 5 & 081 \\
\hline \multirow{5}{*}{$\left(490^{\prime}\right)$} & $56-347^{\prime}$ QMS & LIM, QVN, SUL & $55-60$ & 5 & 1.14 \\
\hline & & & $65-75$ & 10 & 1.64 \\
\hline & $347-405^{\prime}$ GRST & QVN, BLCH, PYIASPY & & & \\
\hline & 405-487' QMS & QVN, BLCH, PYIASPY & & & \\
\hline & $487-490^{\prime}$ GRST & TRACE PYIASPY & & & \\
\hline & & & & & \\
\hline OD-9 & $0-109^{\prime}$ QMS & LIM, QVN & $25-30$ & 5 & 1.23 \\
\hline \multirow[t]{3}{*}{$\left(470^{\prime}\right)$} & & & $90-105$ & 15 & 0,66 \\
\hline & 109-344' FELSITE & LIM, ARG/SER & & & \\
\hline & $344-470^{\prime}$ QMS & QVN,SER,PYIASPY & $365-370$ & 5 & 0.45 \\
\hline & & & & & \\
\hline OD-10 & $0-247^{\prime} \mathrm{QMS}$ & $\mathrm{LIM}, \pm B L C H, Q V N$ & $120-130$ & 10 & 0.82 \\
\hline \multirow[t]{2}{*}{$\left(390^{\prime}\right)$} & & & $190-195$ & 5 & 0.40 \\
\hline & 247-390' GRST & $\mathrm{QVN}, \pm \mathrm{BLCH}, \mathrm{PY}$ & & & \\
\hline & & & & & \\
\hline OD-11 & $0-135^{\prime}$ QMS & LIM, HEM, QVN & $55-60$ & 5 & 0.53 \\
\hline \multirow[t]{4}{*}{$\left(530^{\prime}\right)$} & & & $115-120$ & 5 & 0.34 \\
\hline & 135-147' FELSITE & ARG,LIM, TR-PY & $135-140$ & 5 & 0.48 \\
\hline & $147-410^{\prime}$ QMS & QVN,BLCH,PY/ASPY & $145-150$ & 5 & 0.72 \\
\hline & $410-530^{\prime}$ GRST & QVN, $+B L C H, \pm P Y / A S P Y$ & & & \\
\hline & & & & & \\
\hline
\end{tabular}




\title{
APPENDIX 2.
}

1996 CYPRUS GOLD EXPLORATION

\author{
ALASKA \\ DRILL SAMPLES AND RESULTS \\ OLD DOG PROSPECT
}

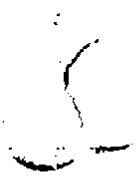




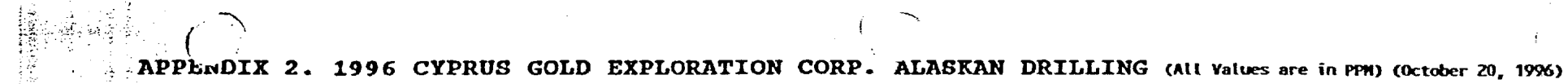

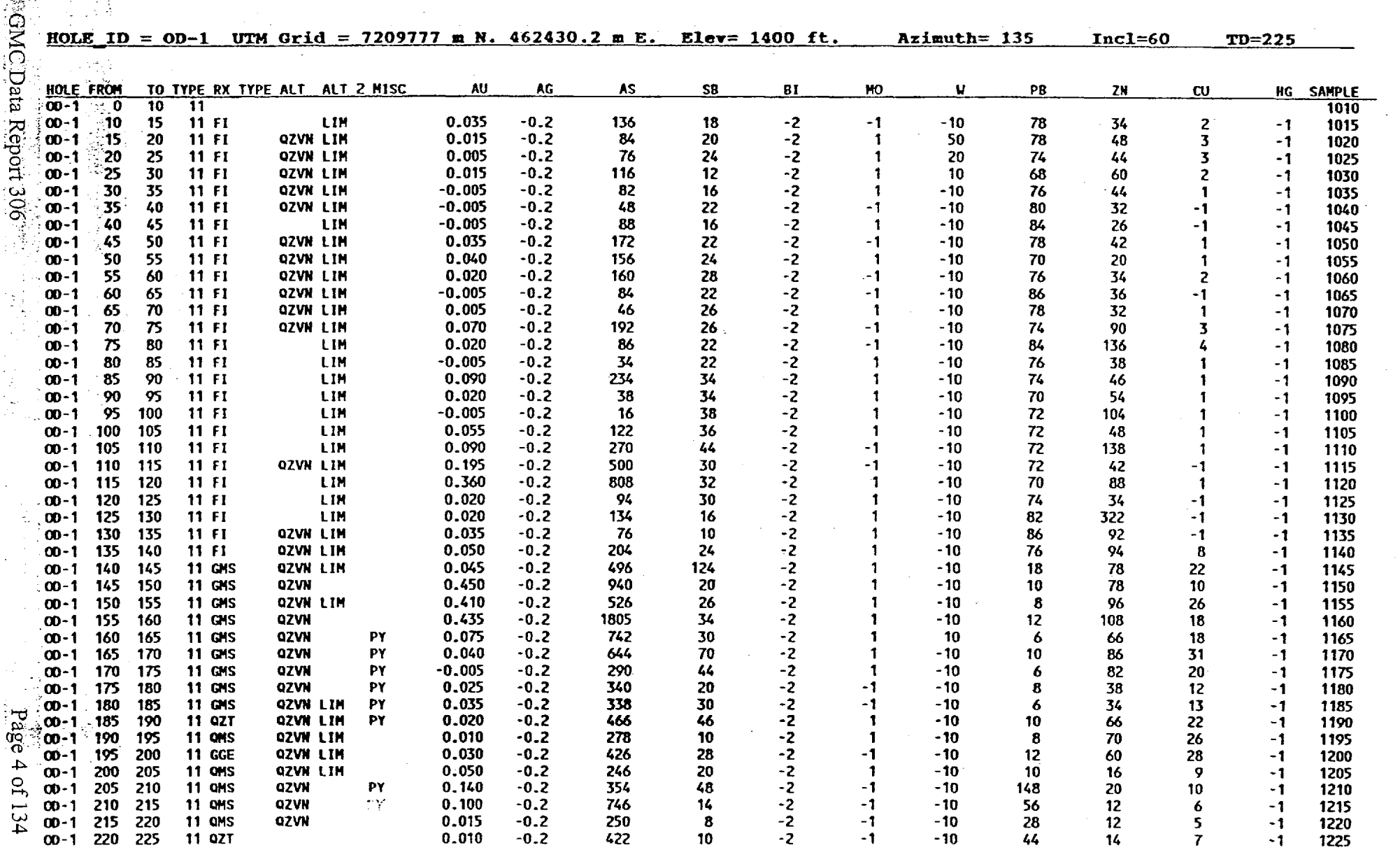




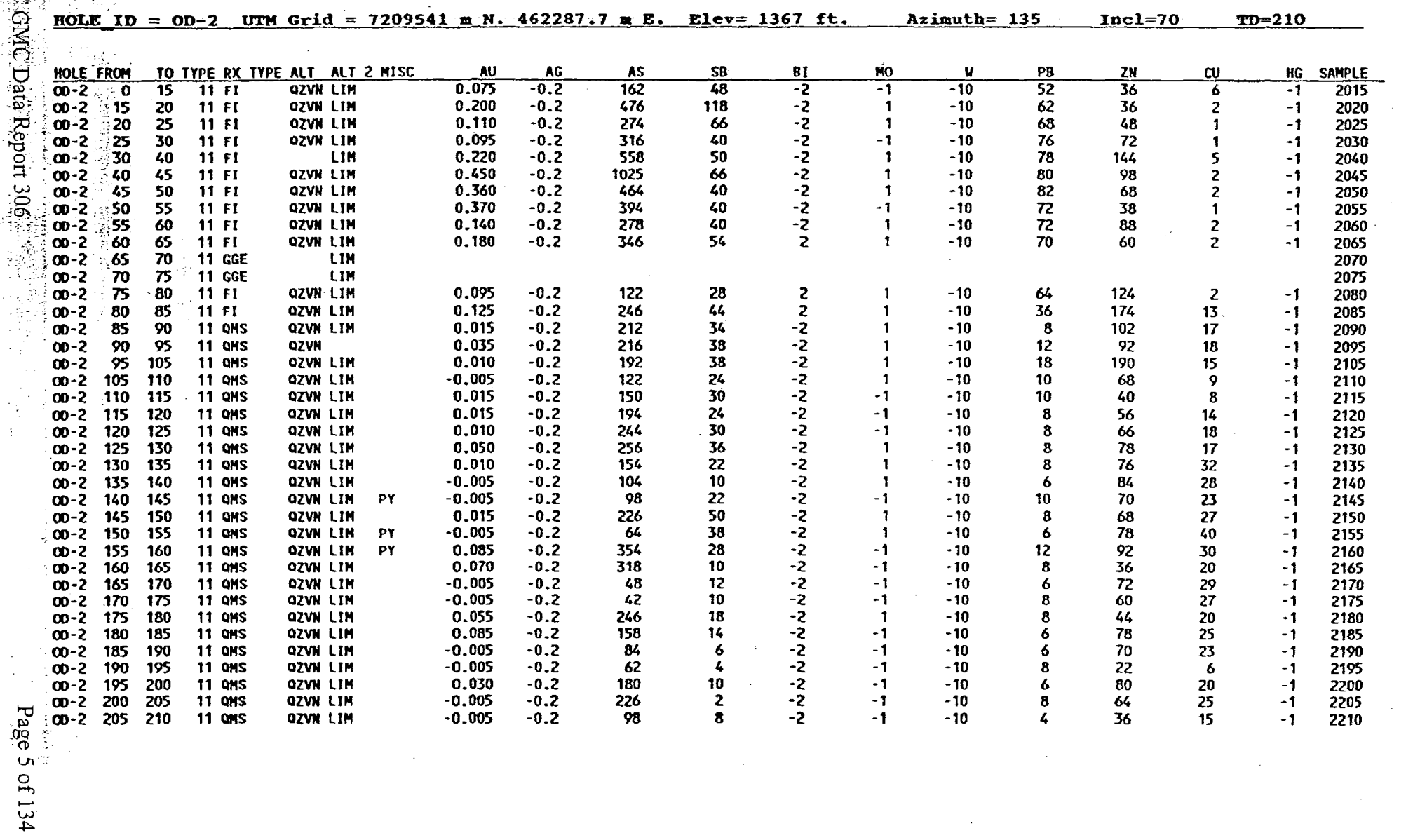




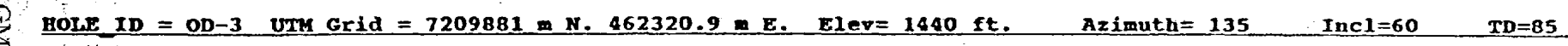

\begin{tabular}{|c|c|c|c|c|c|c|c|c|c|c|c|c|c|c|c|c|c|c|c|}
\hline HOLE & Ekon & ro & YPE RX & IYPE & ALT & ALT & HISC & AU & AG & AS & SB & BI & Mo & $\mathbf{H}$ & PB & $2 \mathrm{~N}$ & $\mathrm{cu}$ & HG & SAMPLE \\
\hline $\mathbf{0 0}=\mathbf{3}$ & 20 & 15 & $11 \mathrm{FI}$ & & OZVW & LIH & SER & 0.265 & -0.2 & 720 & 46 & -2 & -1 & -10 & 68 & 10 & 4 & -1 & 3015 \\
\hline $00-3$ & 15 & 20 & $11 \mathrm{Fl}$ & & azvi & LIN & SER & 0.145 & -0.2 & 200 & 26 & -2 & -1 & -10 & 60 & 10 & 1 & -1 & 3020 \\
\hline $\boldsymbol{\infty}-\mathbf{3}$ & 20 & 25 & $11 \mathrm{FI}$ & & OzVK & LIM & SER & 0.070 & -0.2 & 178 & 22 & -2 & -1 & -10 & 62 & 6 & 1 & -1 & 3025 \\
\hline $00-3$ & 25 & 30 & $11 \mathrm{FI}$ & & OzVN & LIH & SER & 0.090 & -0.2 & 266 & 20 & -2 & -1 & -10 & 58 & 10 & 1 & -1 & 3030 \\
\hline $\mathbf{0 0 - 3}$ & 30 & 35 & $11 \mathrm{FI}$ & & OzVN & LIH & SER & 0.250 & -0.2 & 522 & 28 & -2 & 1 & -10 & 64 & 2 & 1 & -1 & 3035 \\
\hline$\infty-3$ & 35 & 40 & $11 \mathrm{FI}$ & & QZVW & LIM & SER & 0.190 & -0.2 & 644 & 22 & -2 & -1 & -10 & 70 & 4 & 1 & -1 & 3040 \\
\hline$\infty=3$ & 840 & 45 & $11 \mathrm{FI}$ & & Qzvi & LIN & SER & 0.525 & -0.2 & 866 & 30 & -2 & -1 & -10 & 68 & 2 & 1 & 1 & 3045 \\
\hline$\infty 0-3$ & 45 & 50 & $11 \mathrm{FI}$ & & OZVN & LIM & SER & 0.910 & 0.2 & 1660 & 46 & -2 & -1 & -10 & 46 & 6 & 4 & -1 & 3050 \\
\hline$\infty 0-3$ & 50 & 55 & $11 \mathrm{FI}$ & & QZVW & LIH & SER & 0.425 & -0.2 & 2040 & 46 & -2 & -1 & -10 & 14 & 72 & 8 & -1 & 3055 \\
\hline$\infty 0-3$ & 55 & 60 & 11 OAS & & azVW & LIH & & 0.295 & -0.2 & 1170 & 86 & -2 & -1 & -10 & 16 & 34 & 11 & -1 & 3060 \\
\hline $00-3$ & 60 & 65 & 11 ons & & QZVH & LIH & & 0.085 & -0.2 & 856 & 40 & -2 & -1 & -10 & 16 & 48 & 18 & -1 & 3065 \\
\hline$\infty 0-3$ & 65 & 70 & 11 OAS & & OzVW & LIH & & 0.285 & -0.2 & 1180 & 28 & -2 & -1 & -10 & 12 & 66 & 11 & -1 & 3070 \\
\hline$\infty 0-3$ & 70 & 75 & 11 ams & & OZVH & LIH & & 2.050 & -0.2 & 5520 & 36 & -2 & -1 & -10 & 12 & 78 & 9 & -1 & $30 \pi$ \\
\hline $00-3$ & 75 & 80 & 11 OMS & & 02VK & LIM & & 2.890 & 0.2 & 6290 & 40 & -2 & -1 & -10 & 36 & 160 & 20 & -1 & 3080 \\
\hline $00-3$ & 80 & 85 & 11 aMs & & OZVN & $\operatorname{LIM}$ & & 1.490 & -0.2 & 2780 & 34 & -2 & 1 & -10 & 28 & 84 & 12 & -1 & 3085 \\
\hline
\end{tabular}




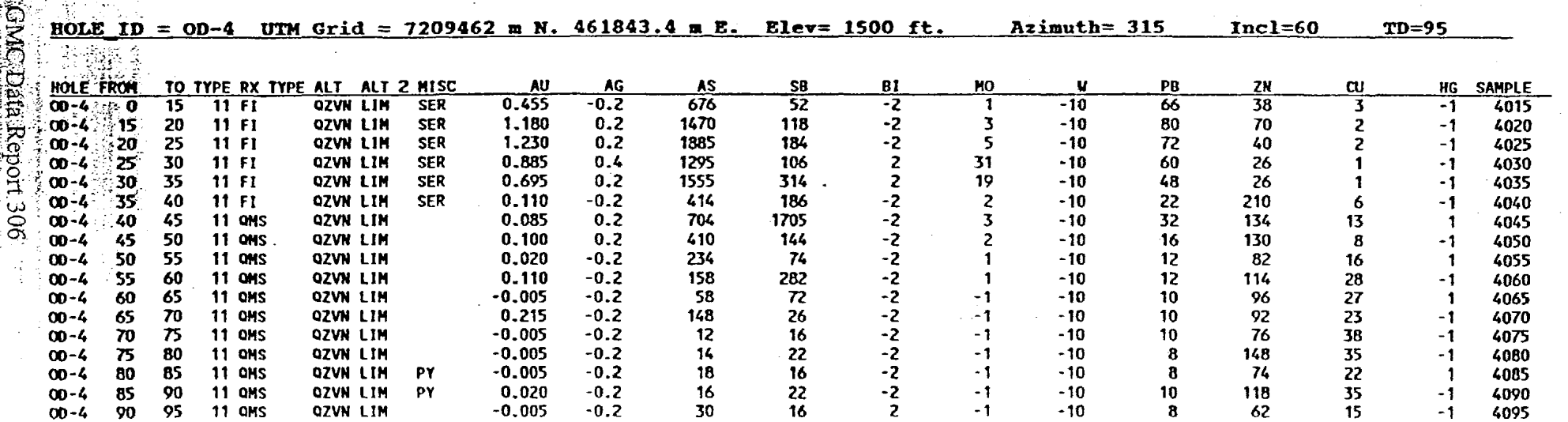




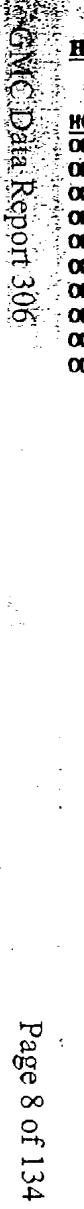

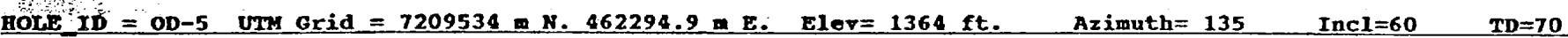

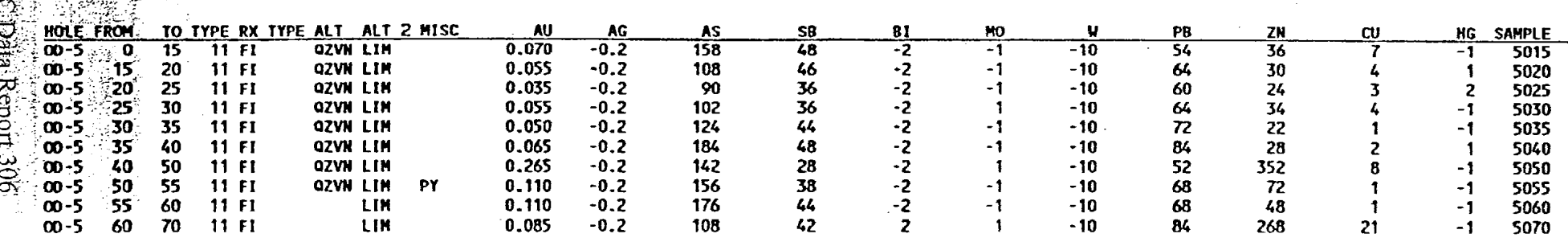




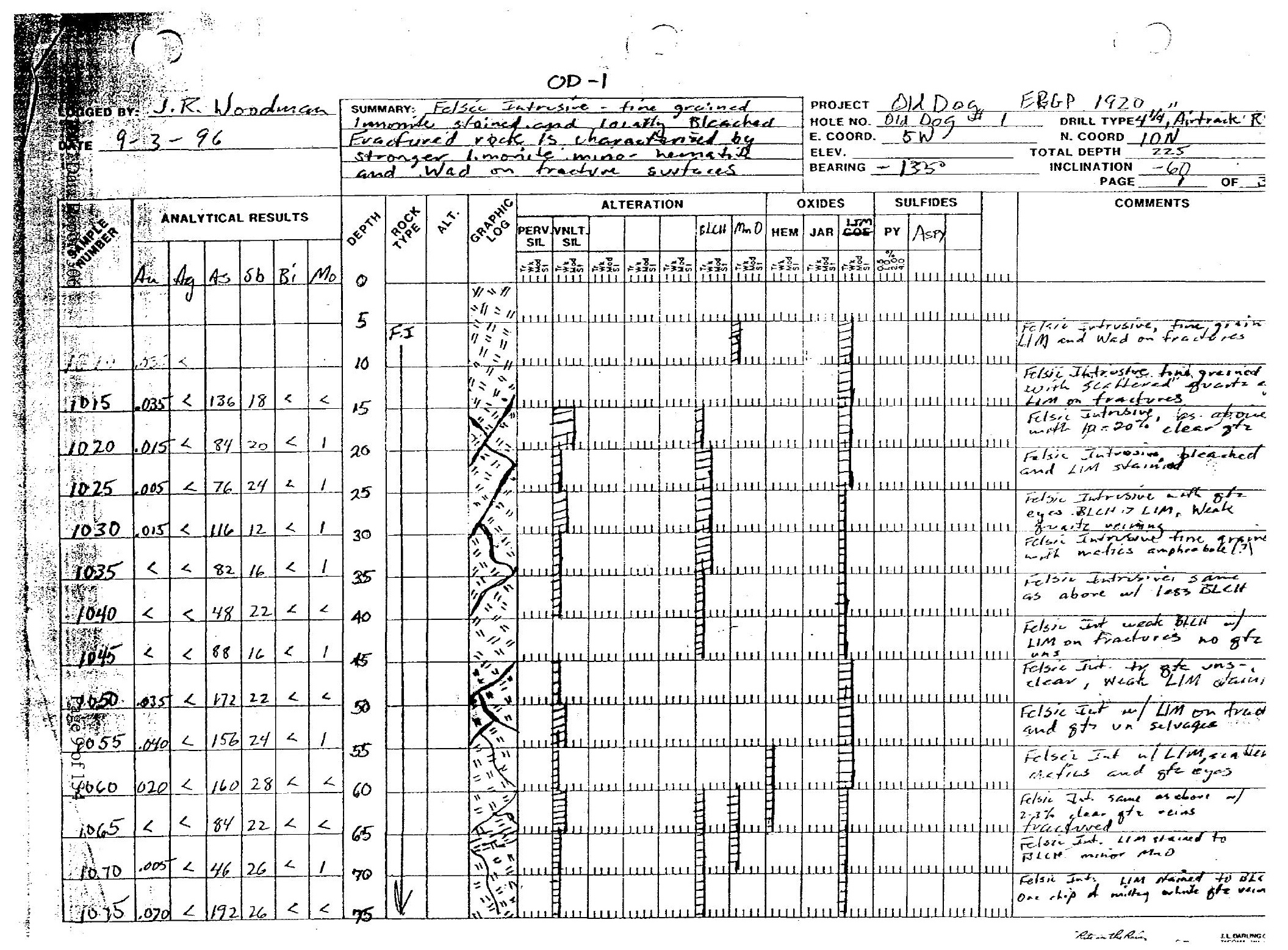




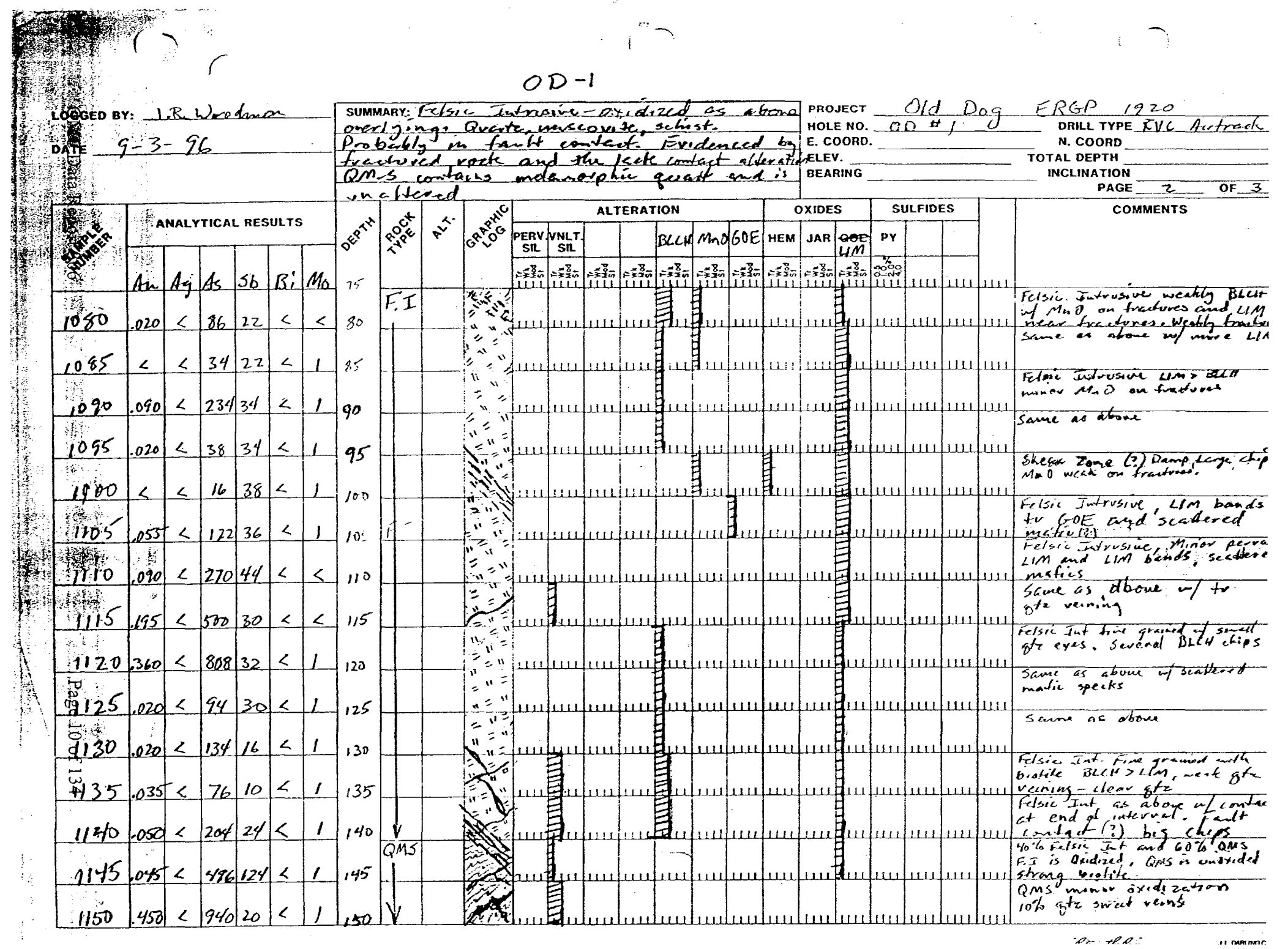




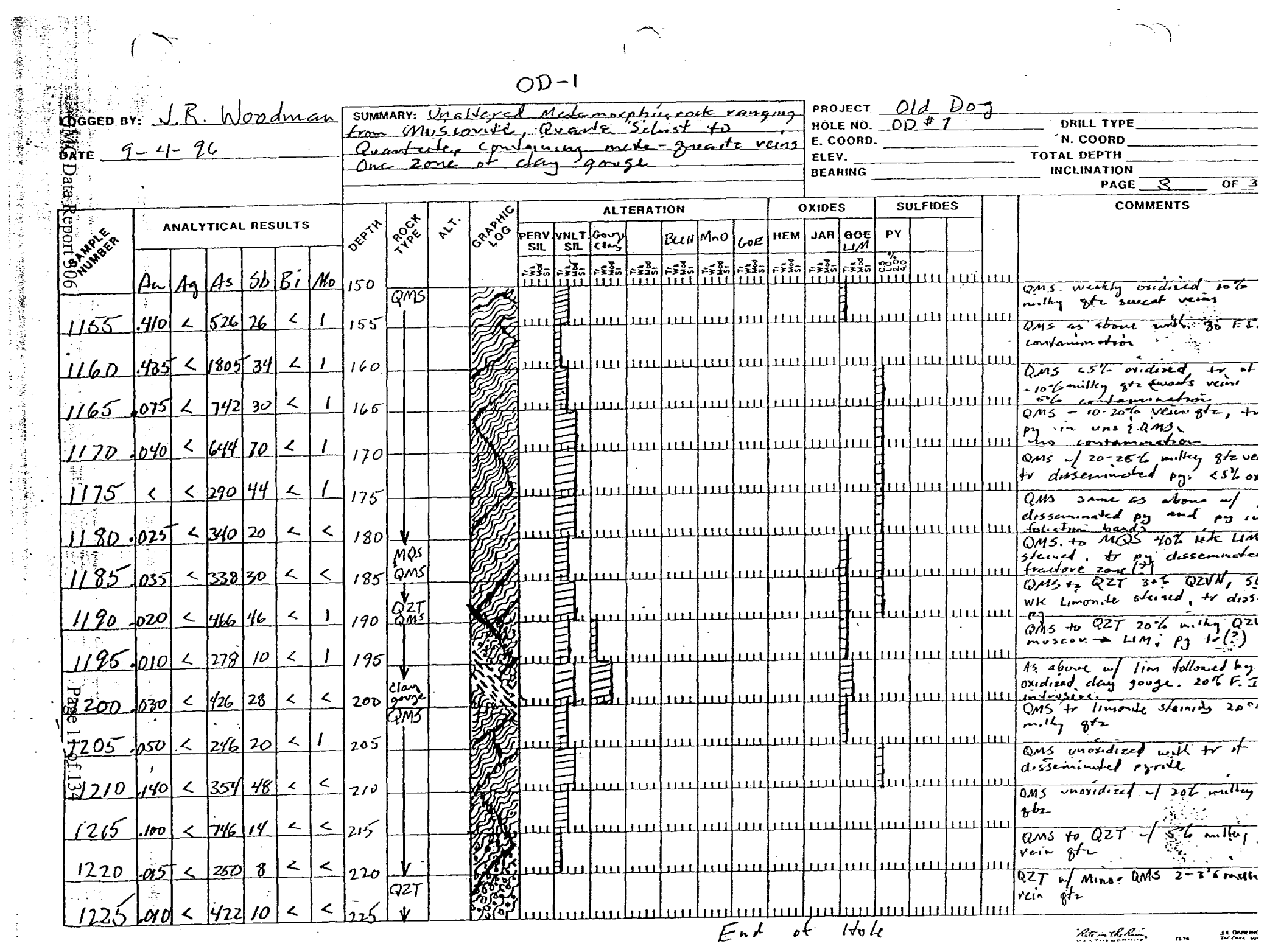




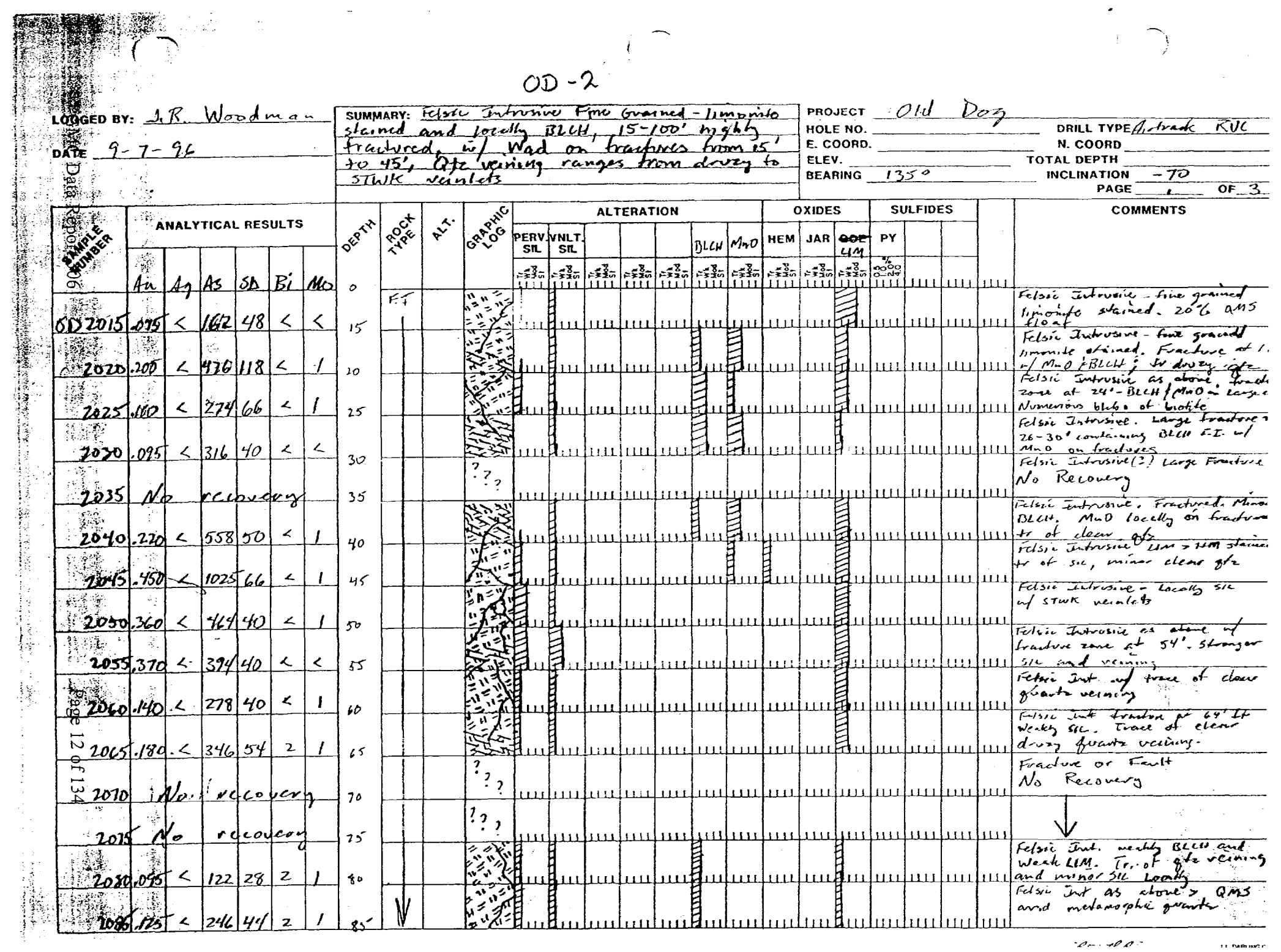




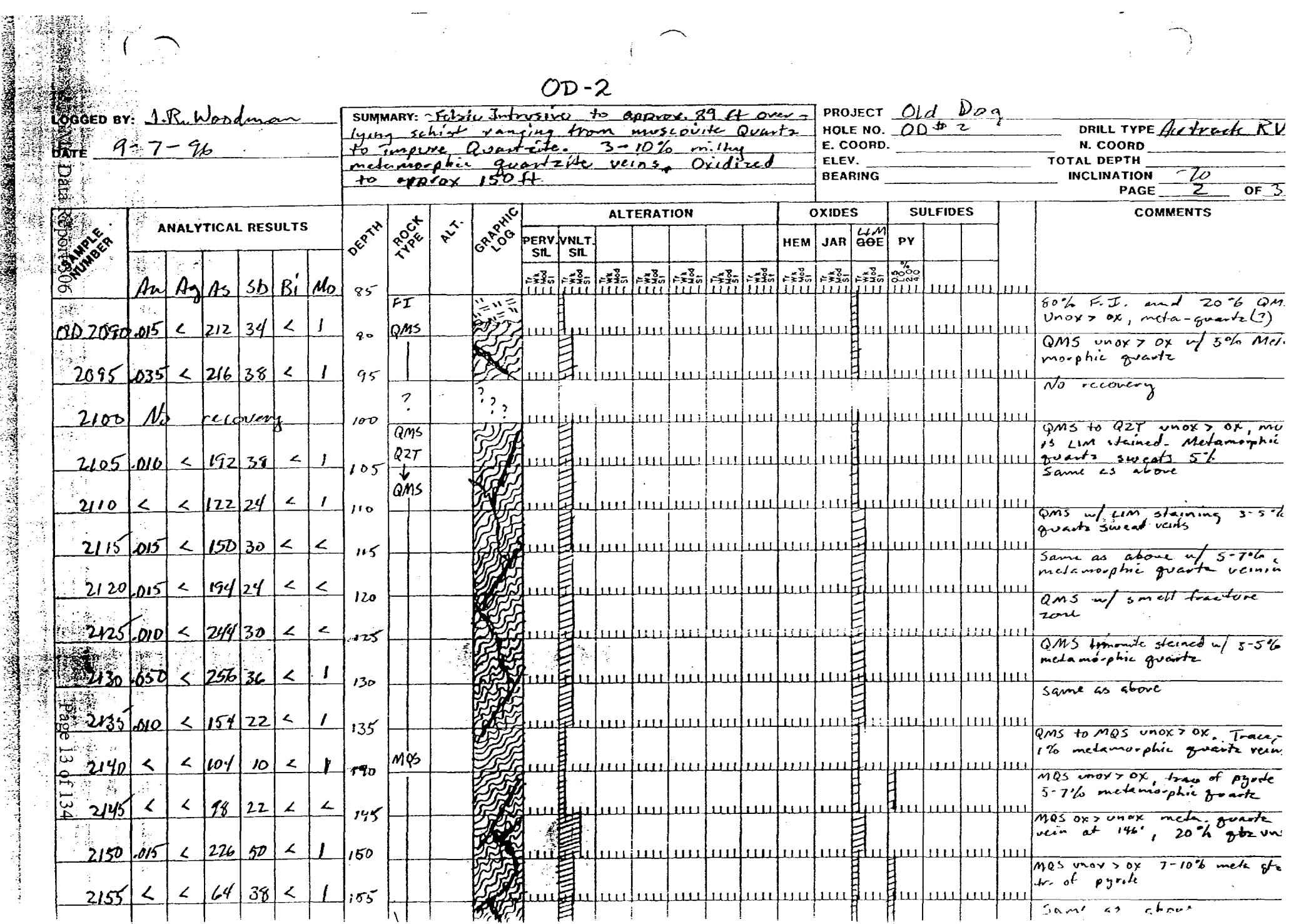


$O D-2$

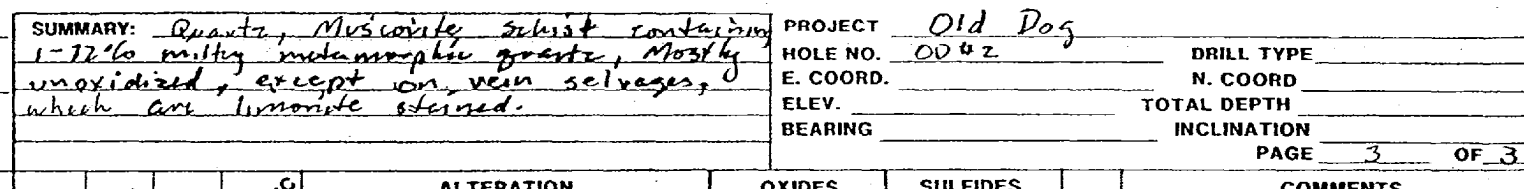

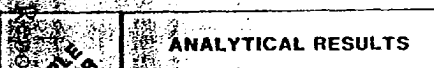

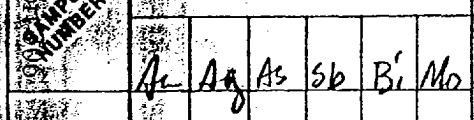

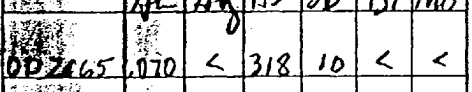
$2110<<\mid 4812<<$ $2175<<4210<<$ $2,80055<24618<1$ 5

$14<2$ 1. $2190<<846<<190$ $495<<624<<195$ if $2200.030<18010<\leq 200$ $2205<<2262<<$ $02240<188<<<$ Hot

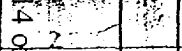
$\begin{aligned} & \omega \\ & +\end{aligned} 2 \leq 0$

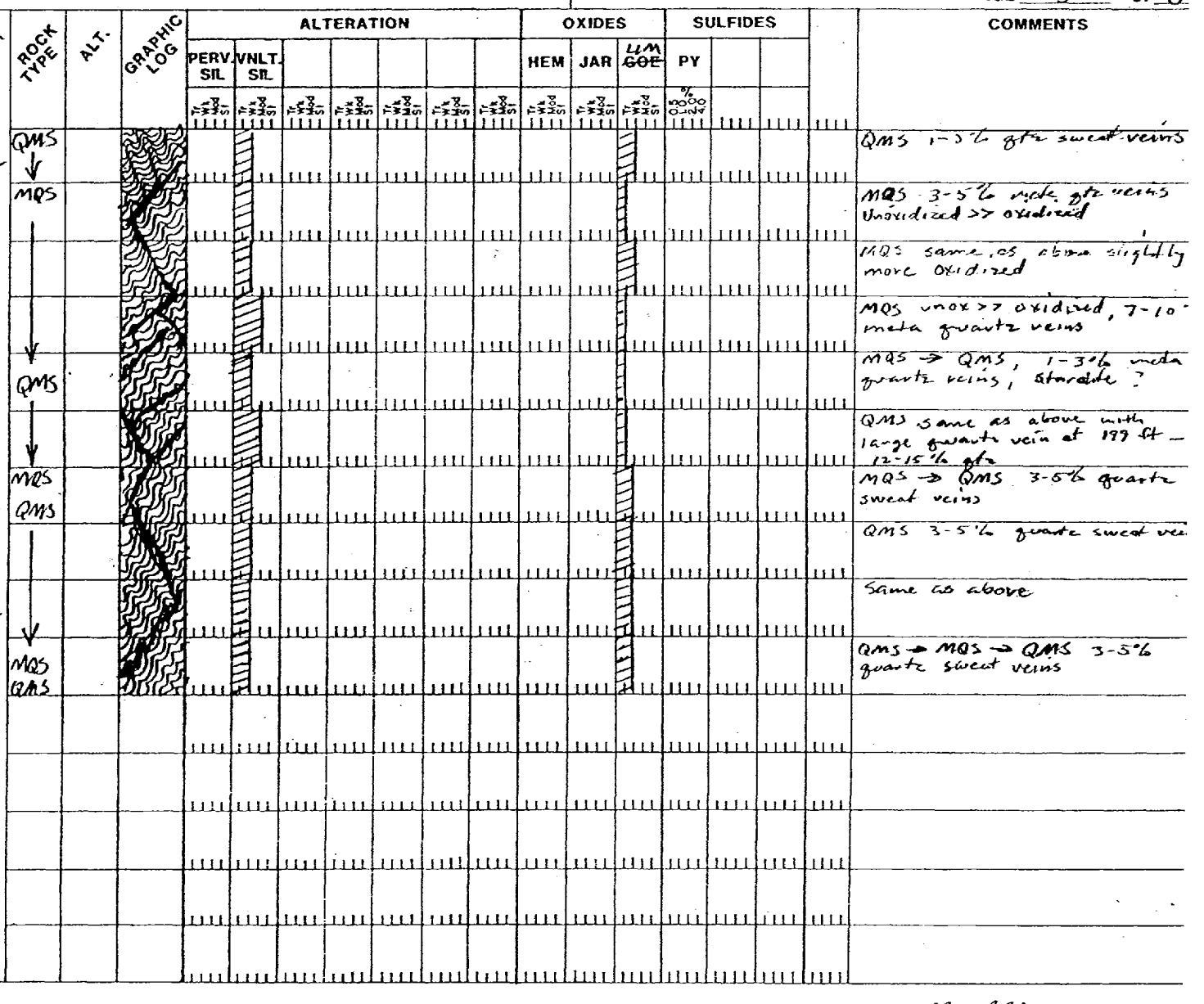

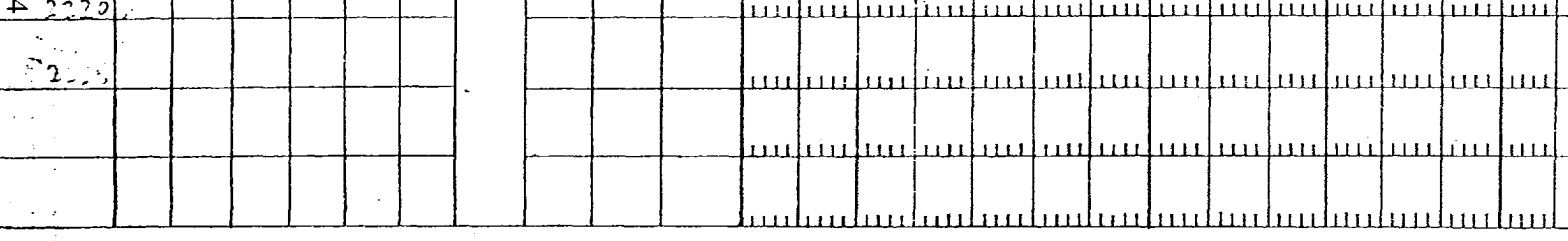




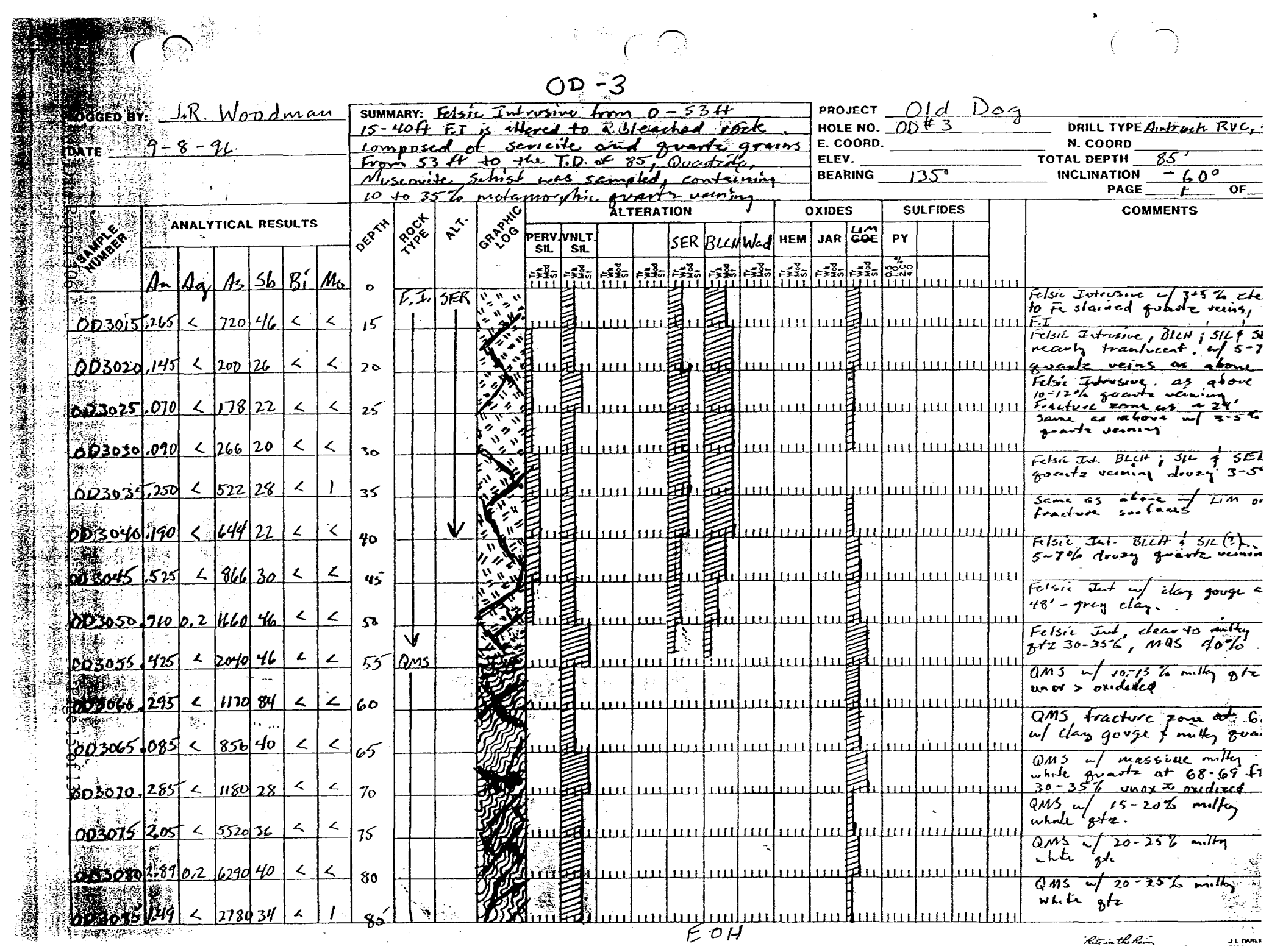




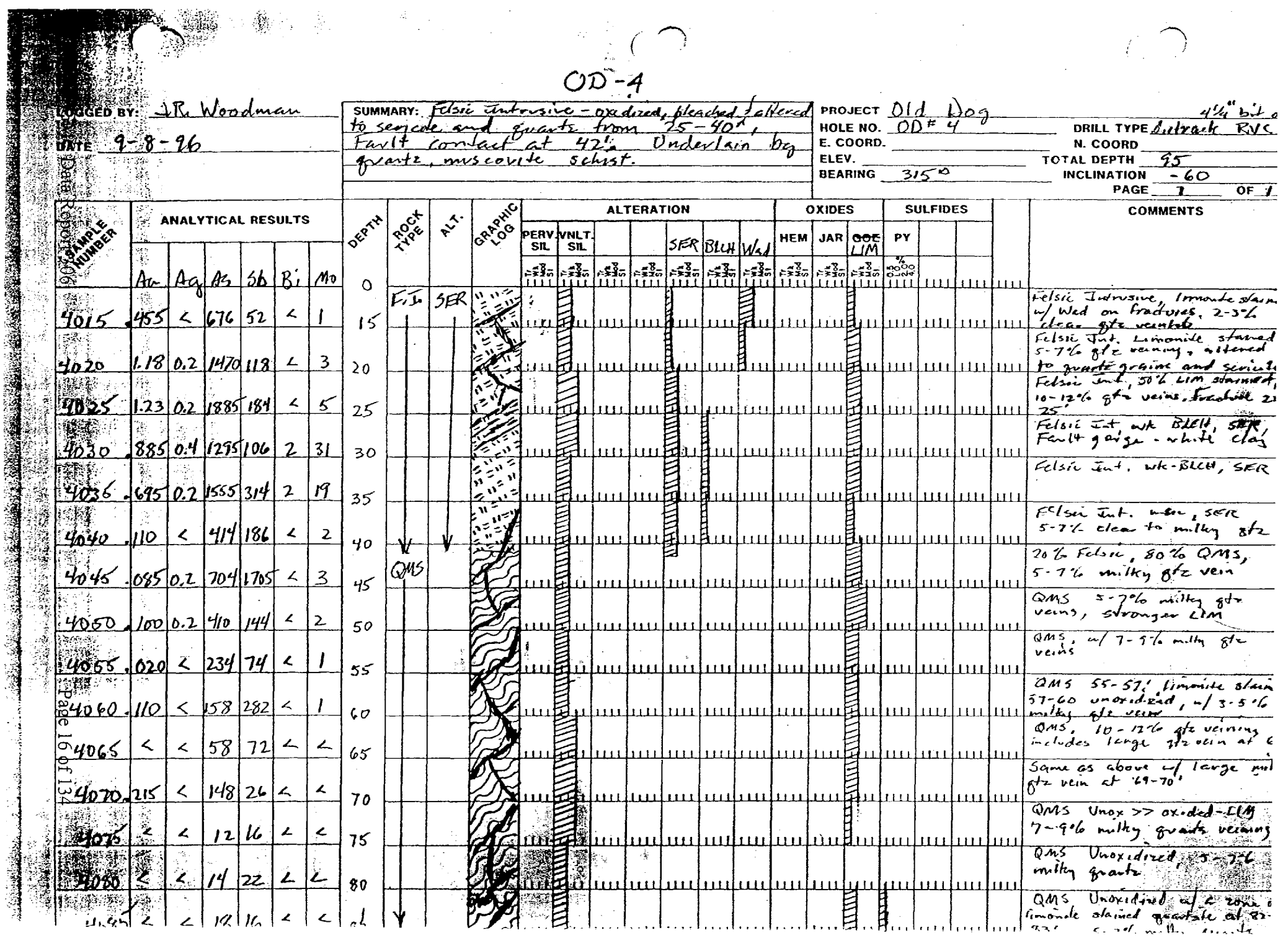




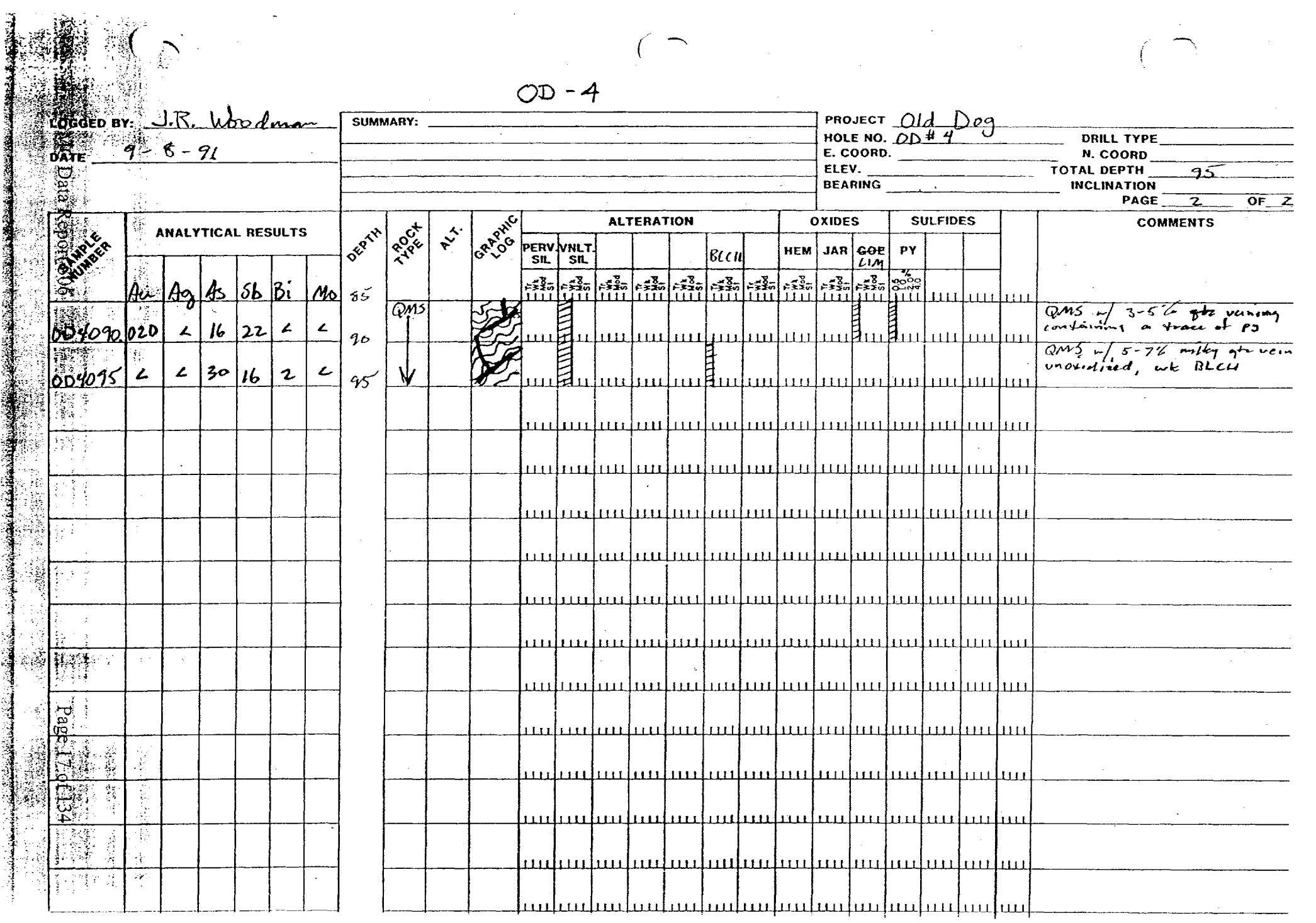




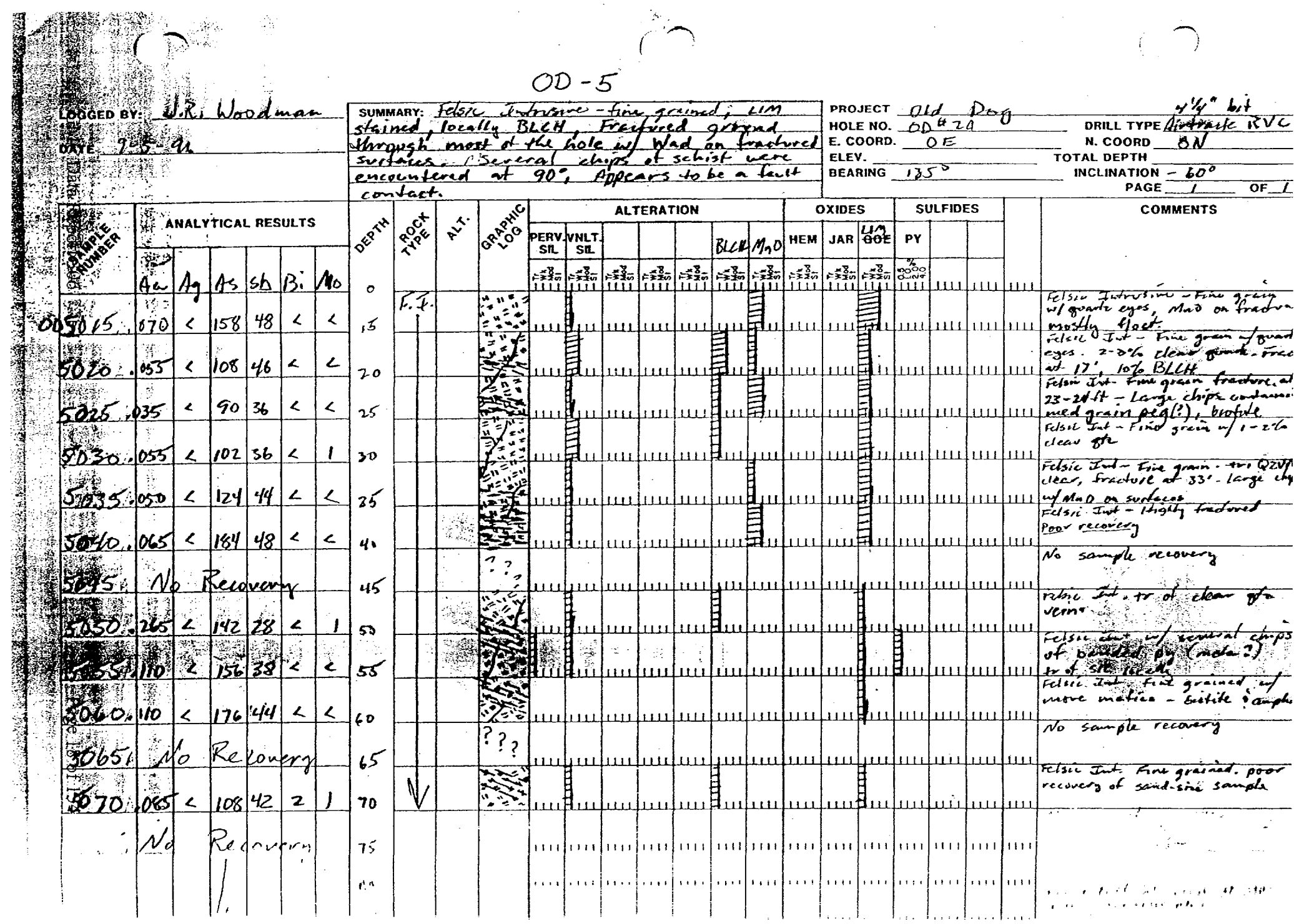




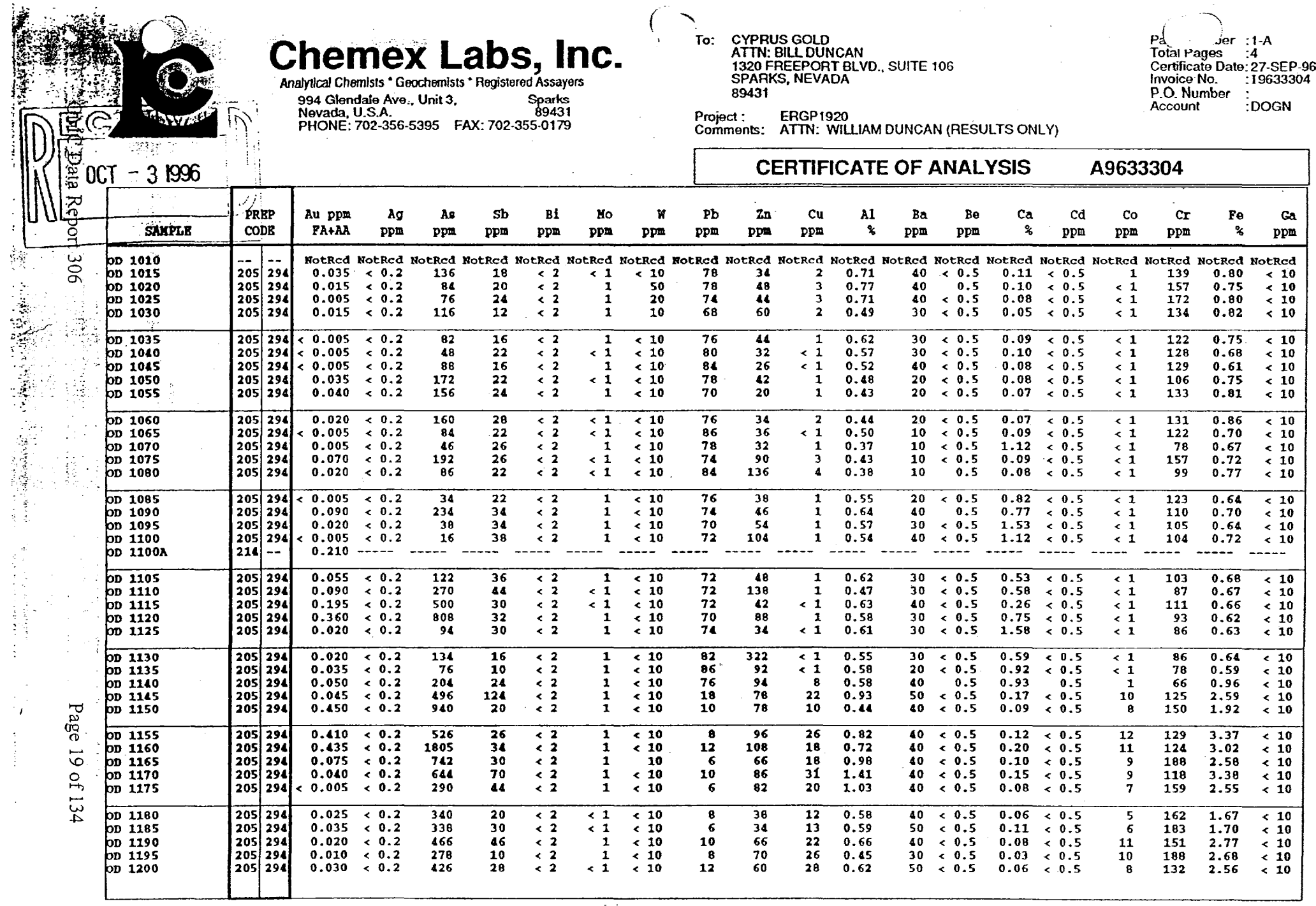

CERTIFICATION: Itautrichlea 


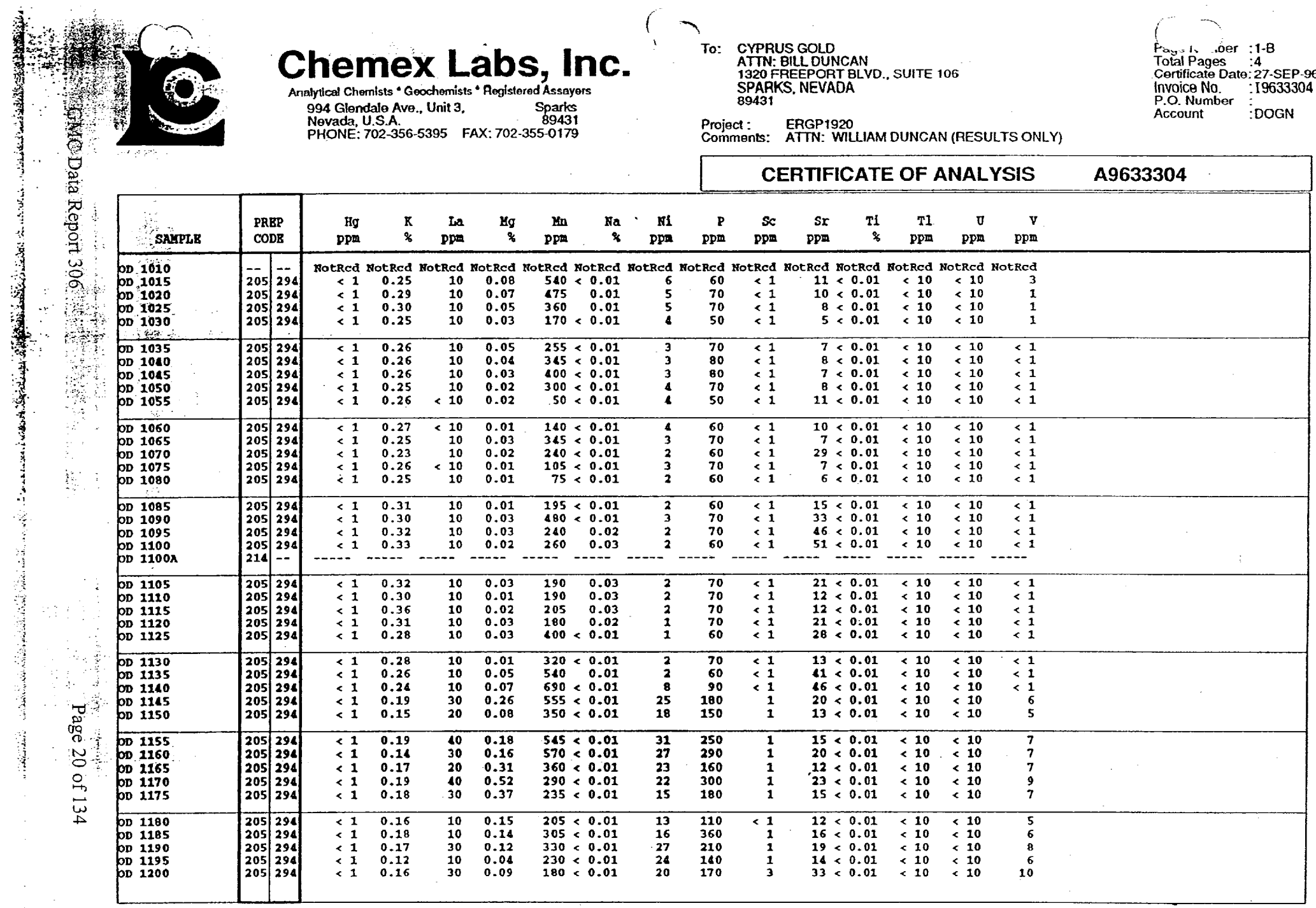




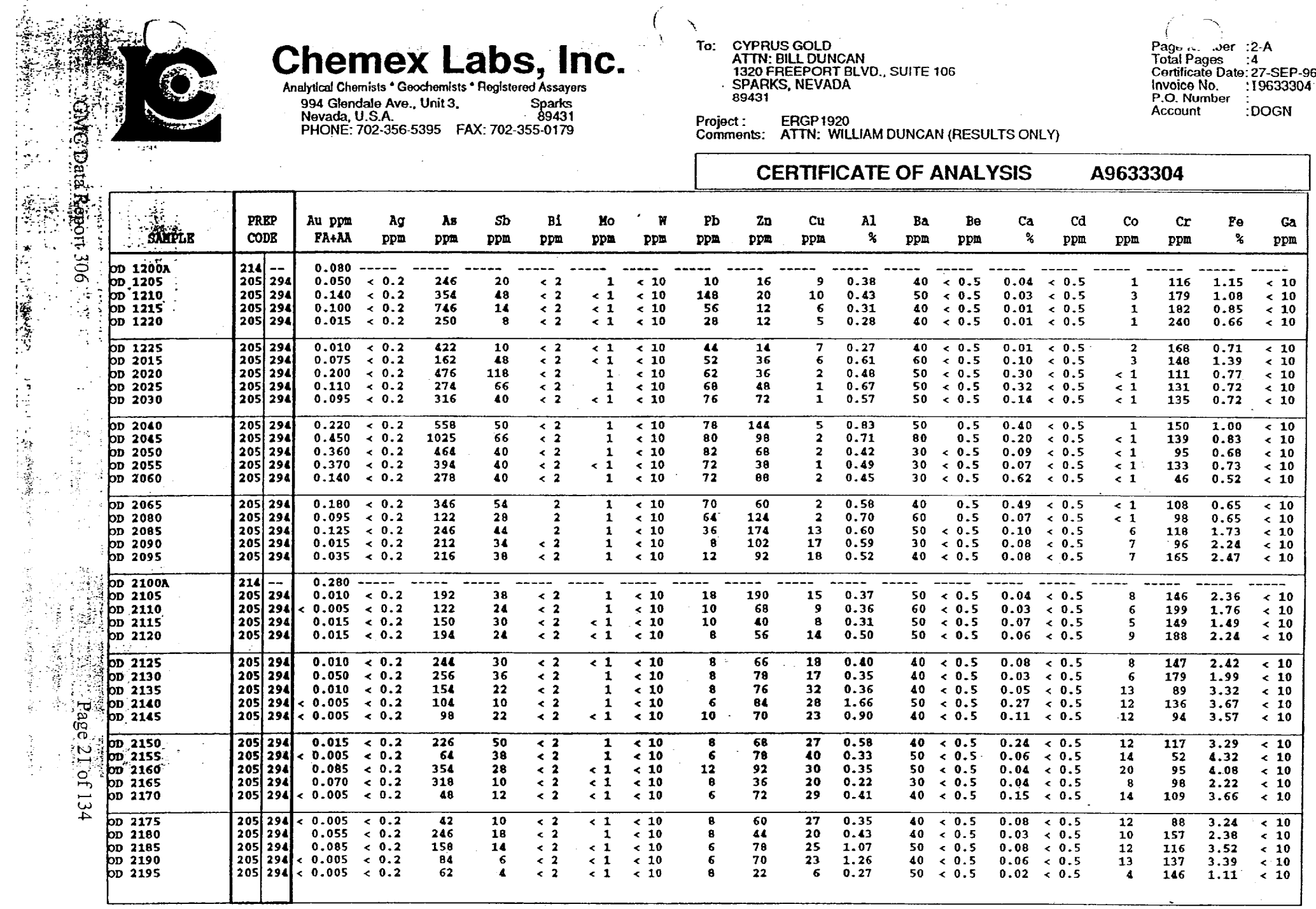




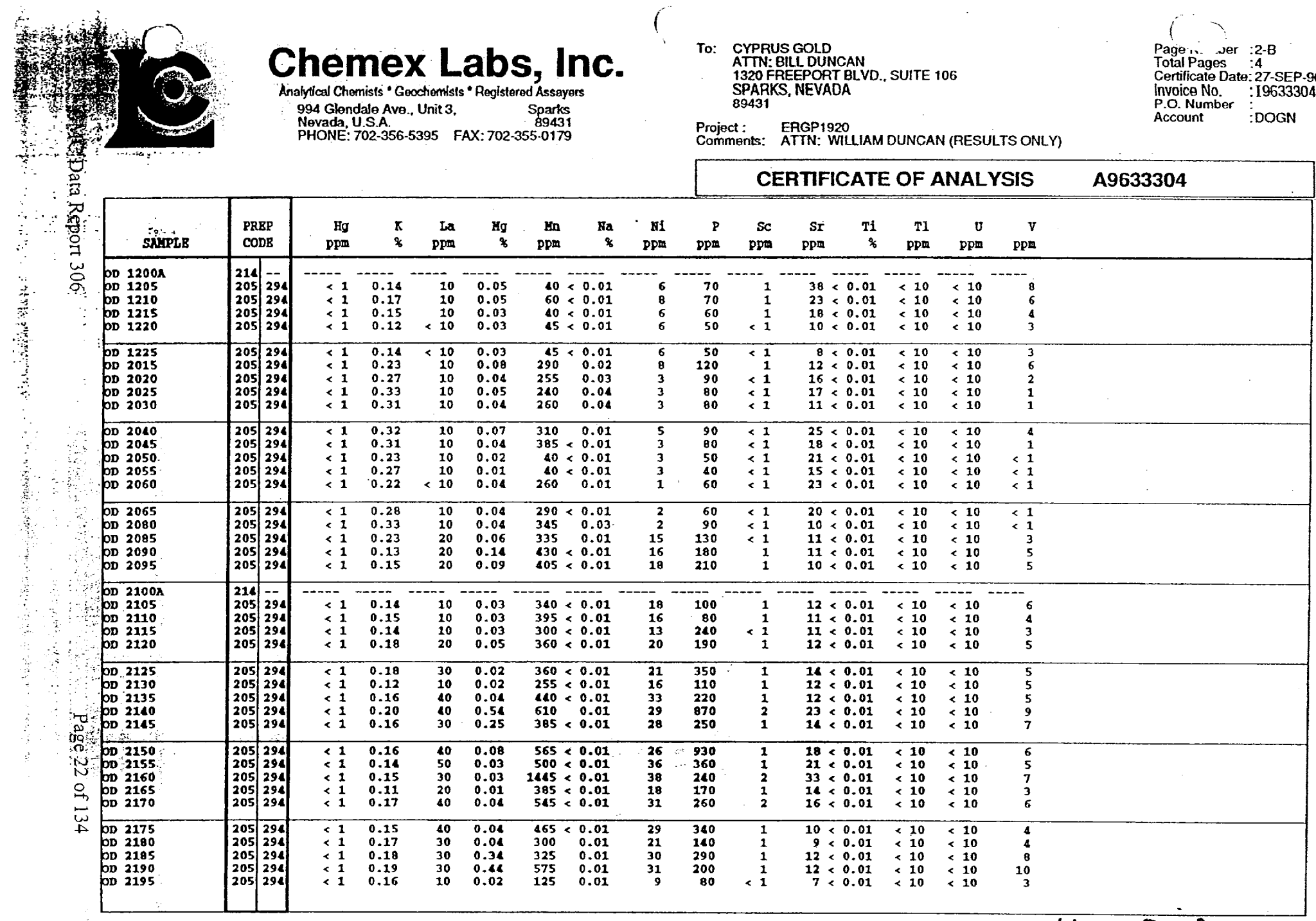




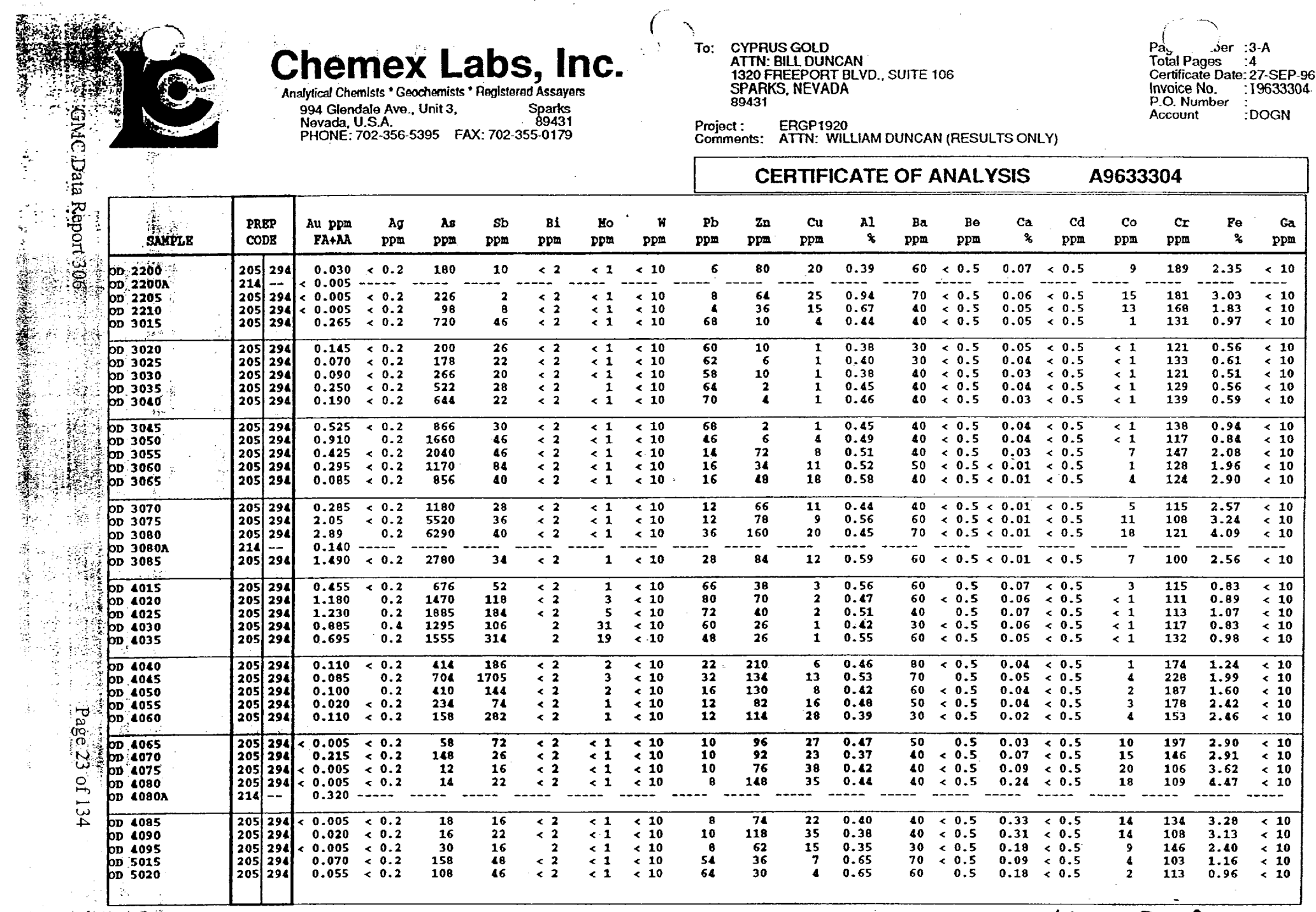




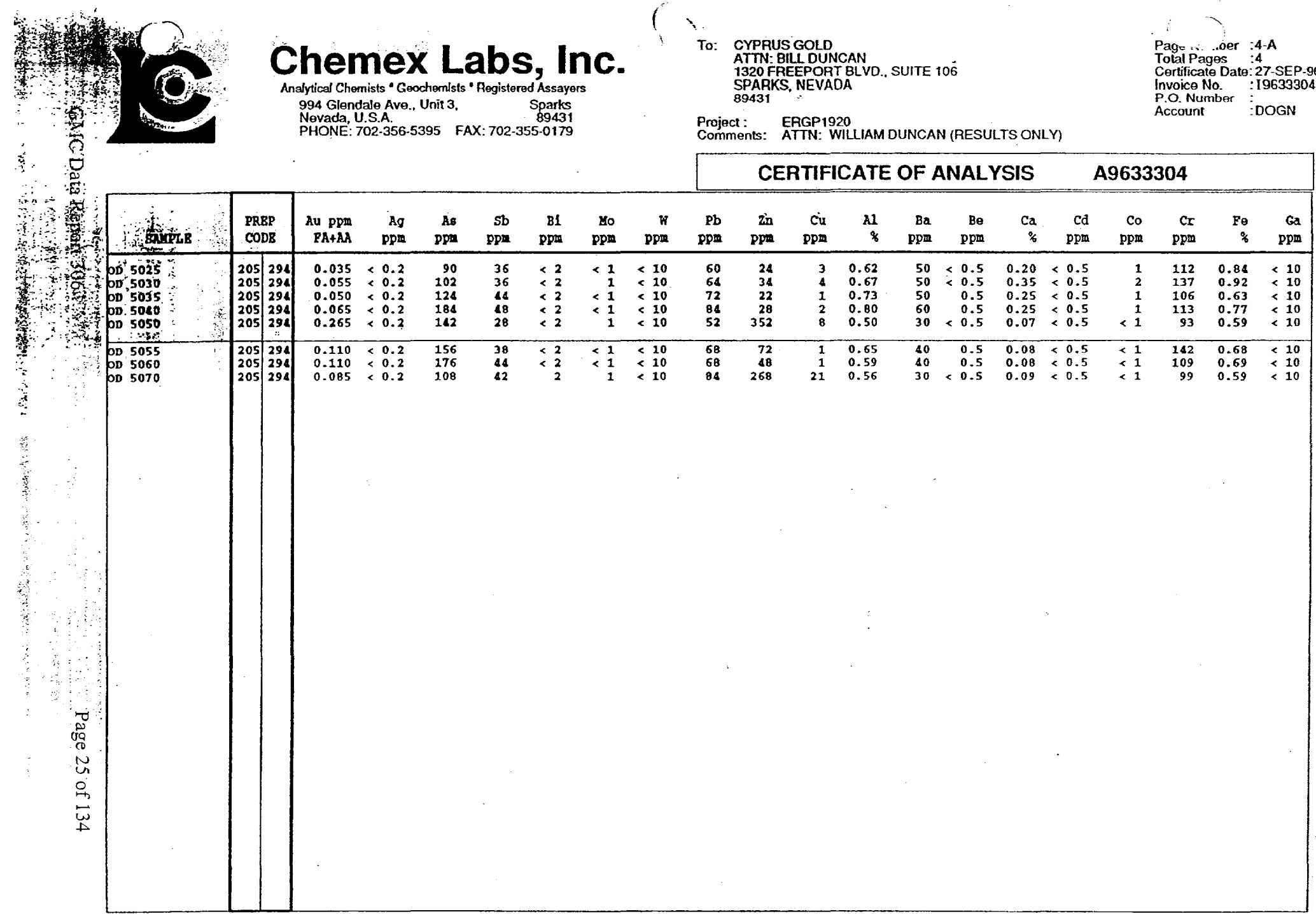

certiFicanon: ItantBuchler 
Chemex Labs, Inc.

Analytical Chemists "Geochomists * Registered Assayers 994 Glendale Ave., Unit 3. Sparks

Nevada, U.S.A.
To: CYPRUS GOLD

ATTN: BILL DUNCAN

1320 FREEPORT BLVD., SUITE 106 SPARKS, NEVADA 89431

Project :

ERGP1920

ATTN: WILLIAM DUNCAN (RESULTS ONLY)

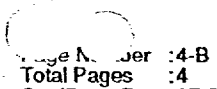

Certificate Date:27-SEP-9 Invoice No. P.O. Numb Account
CERTIFICATE OF ANALYSIS $\quad$ A9633304

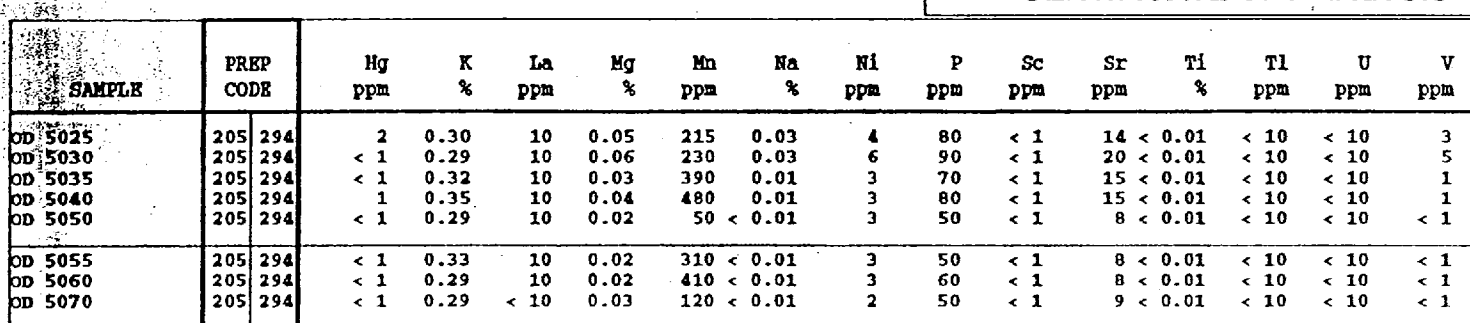




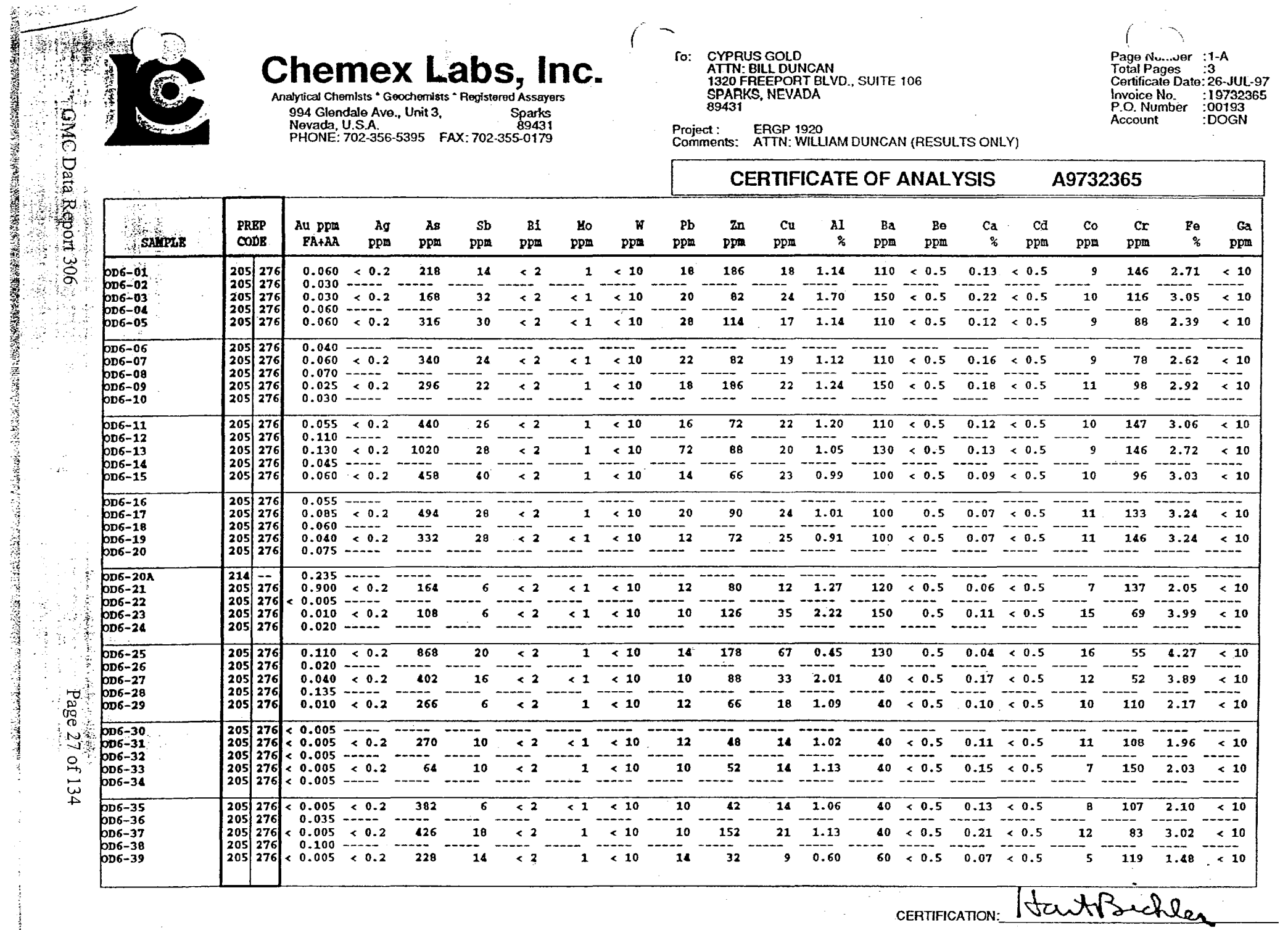




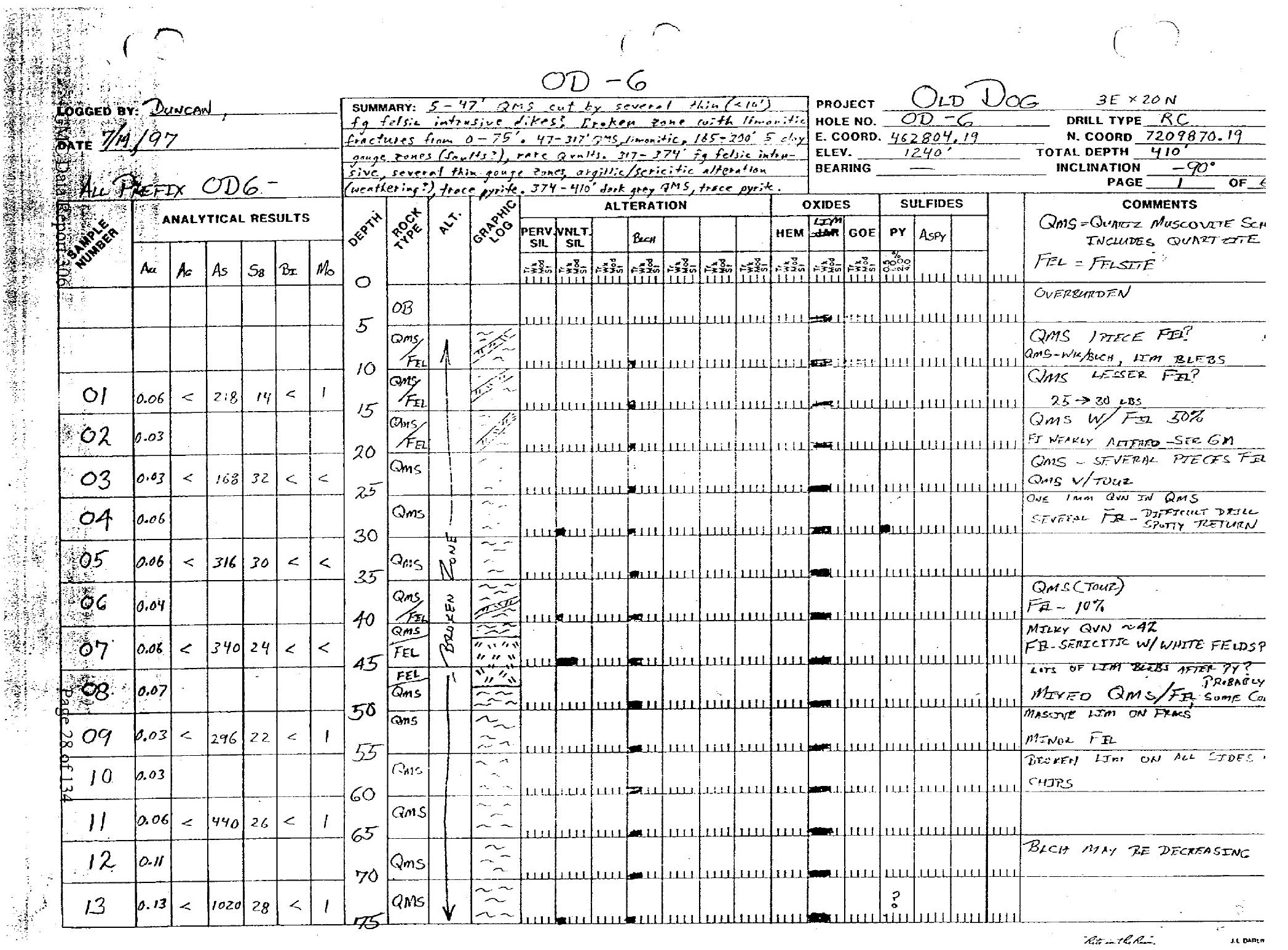




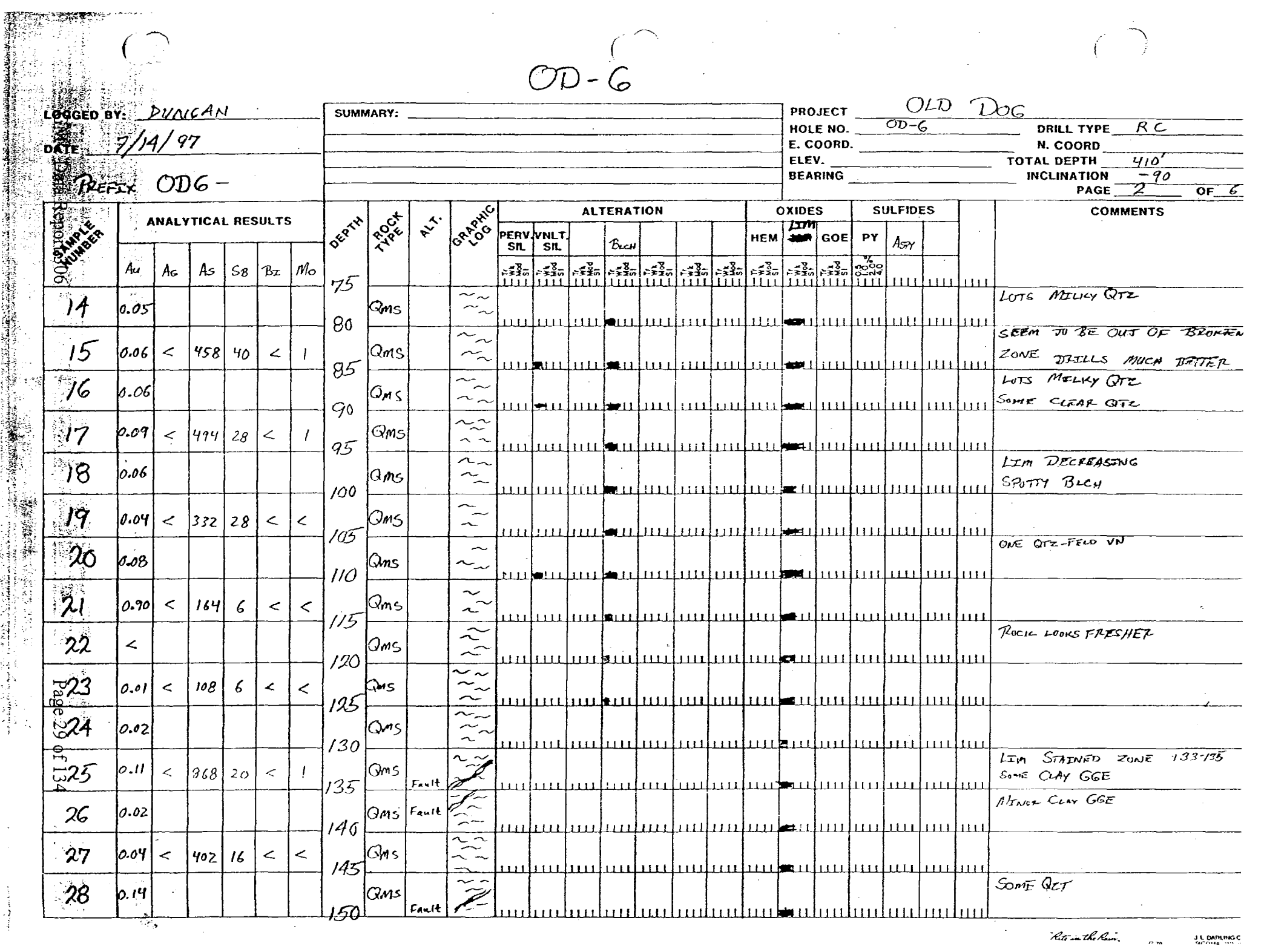




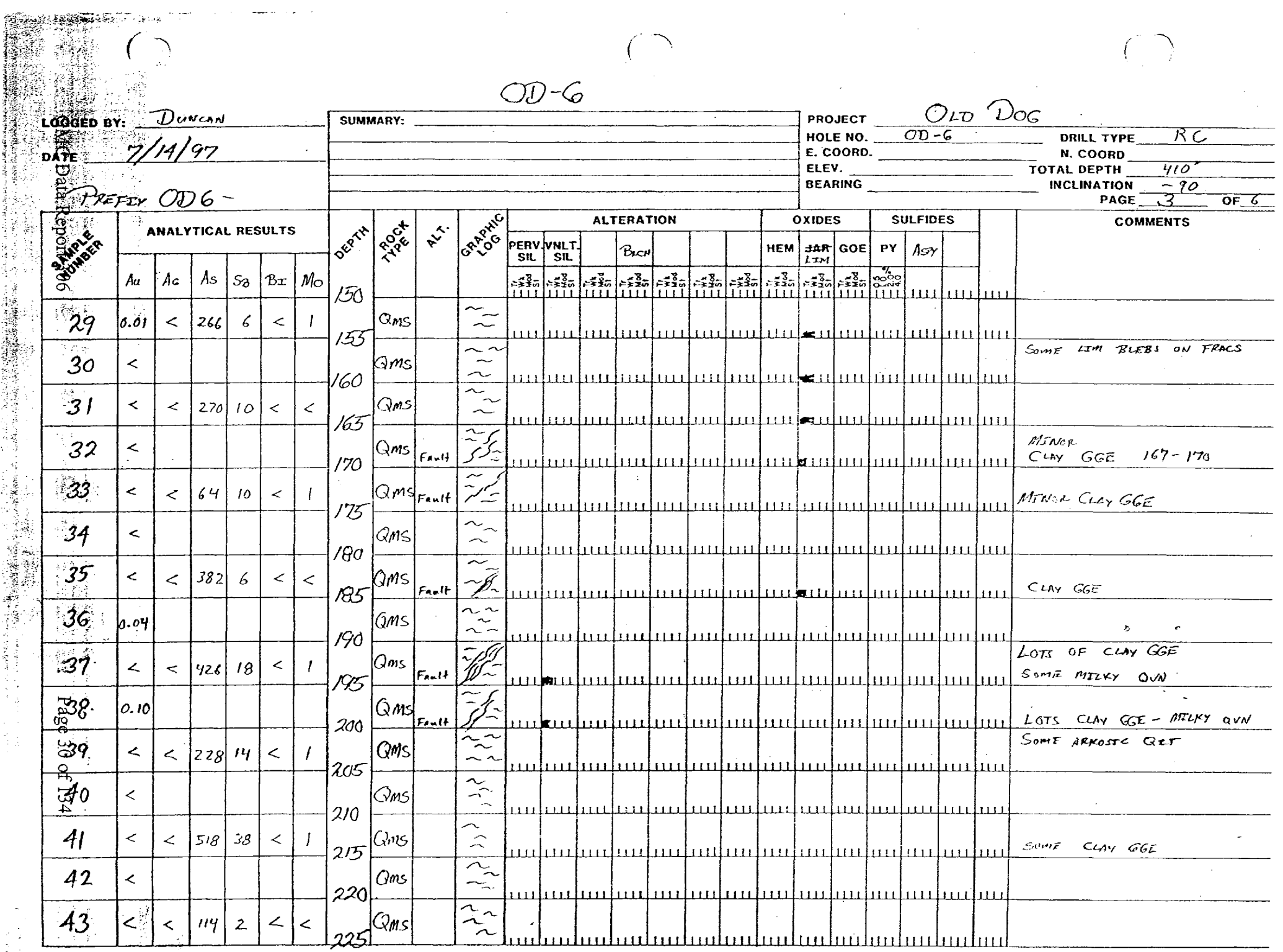




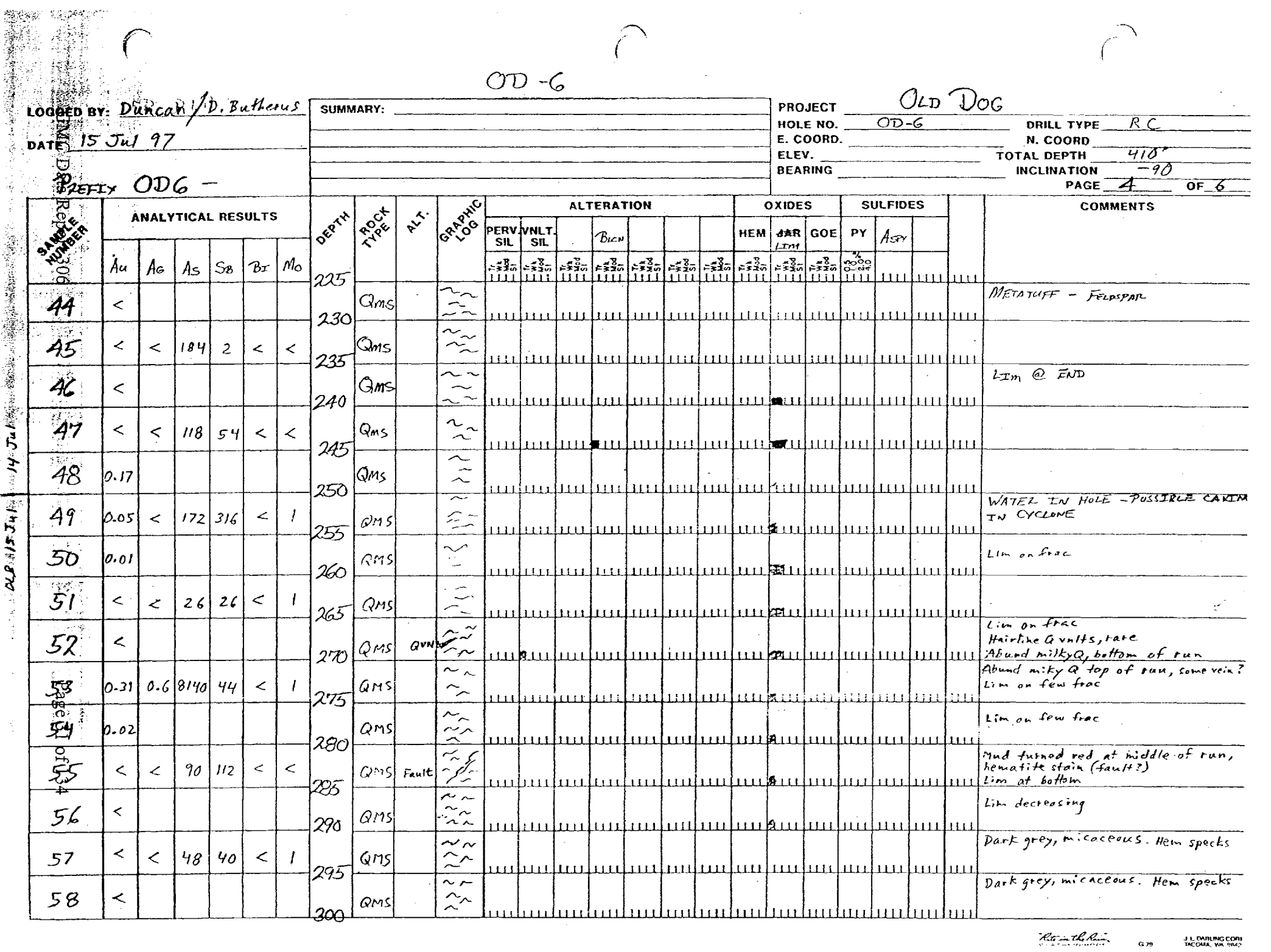




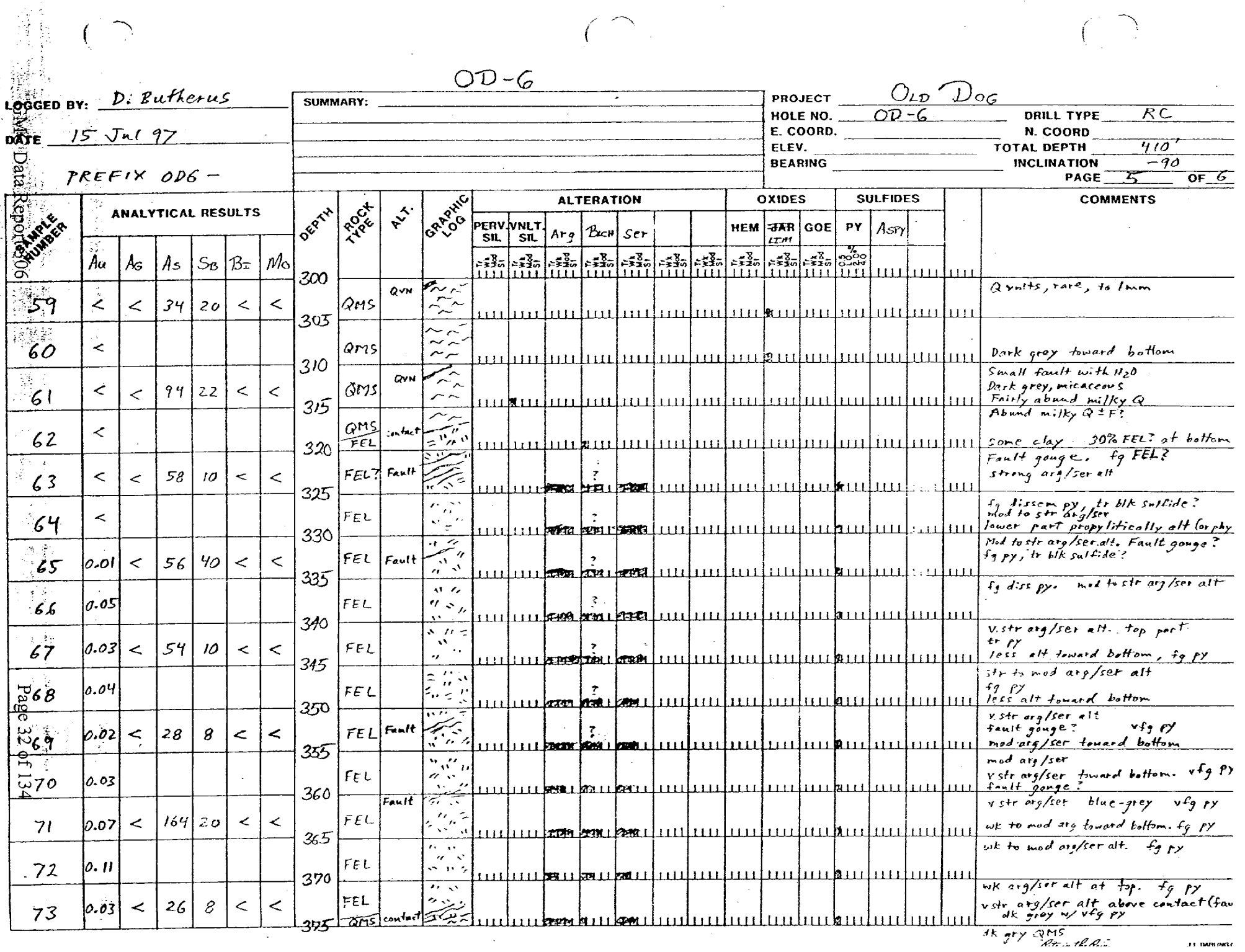




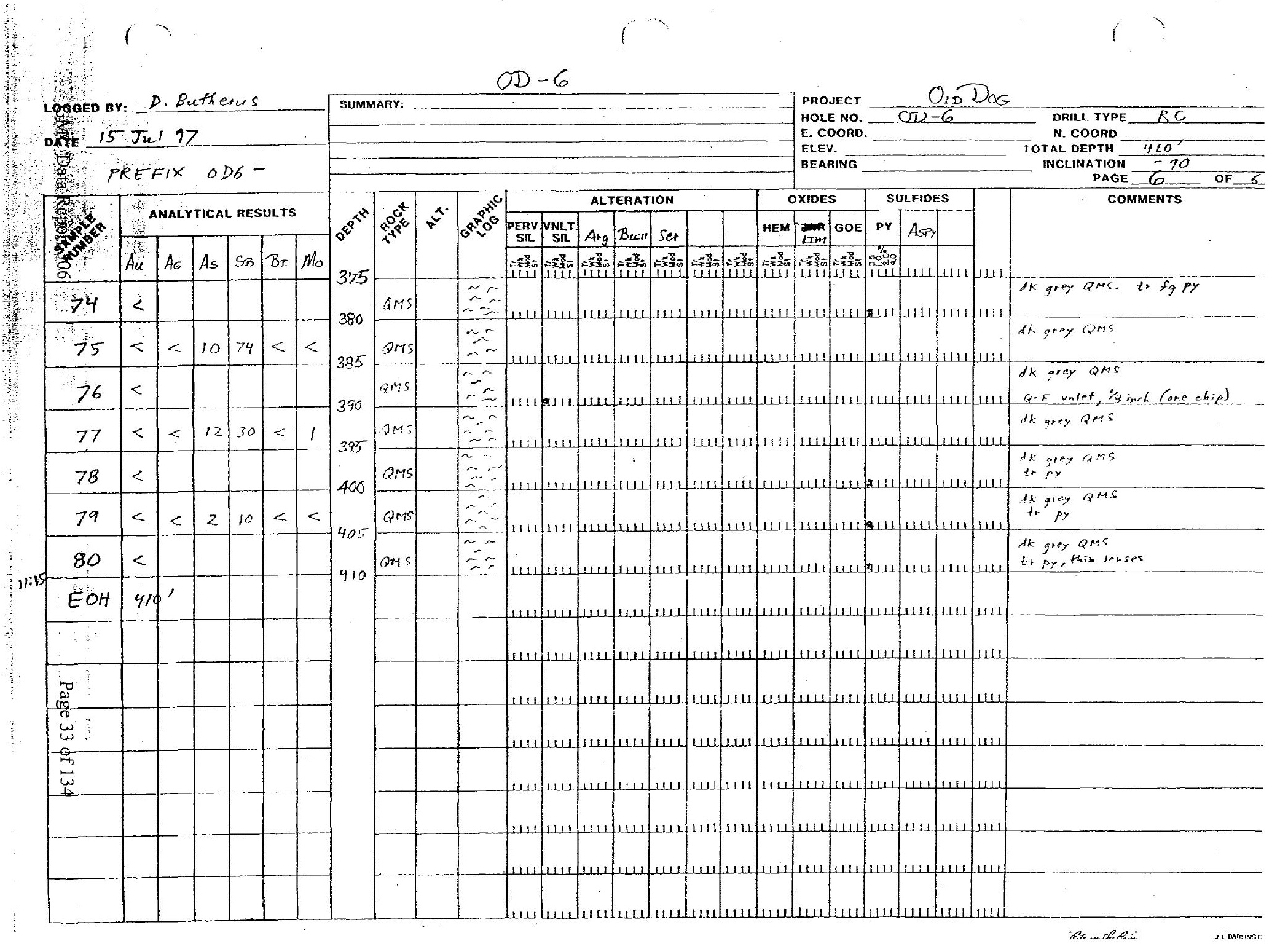




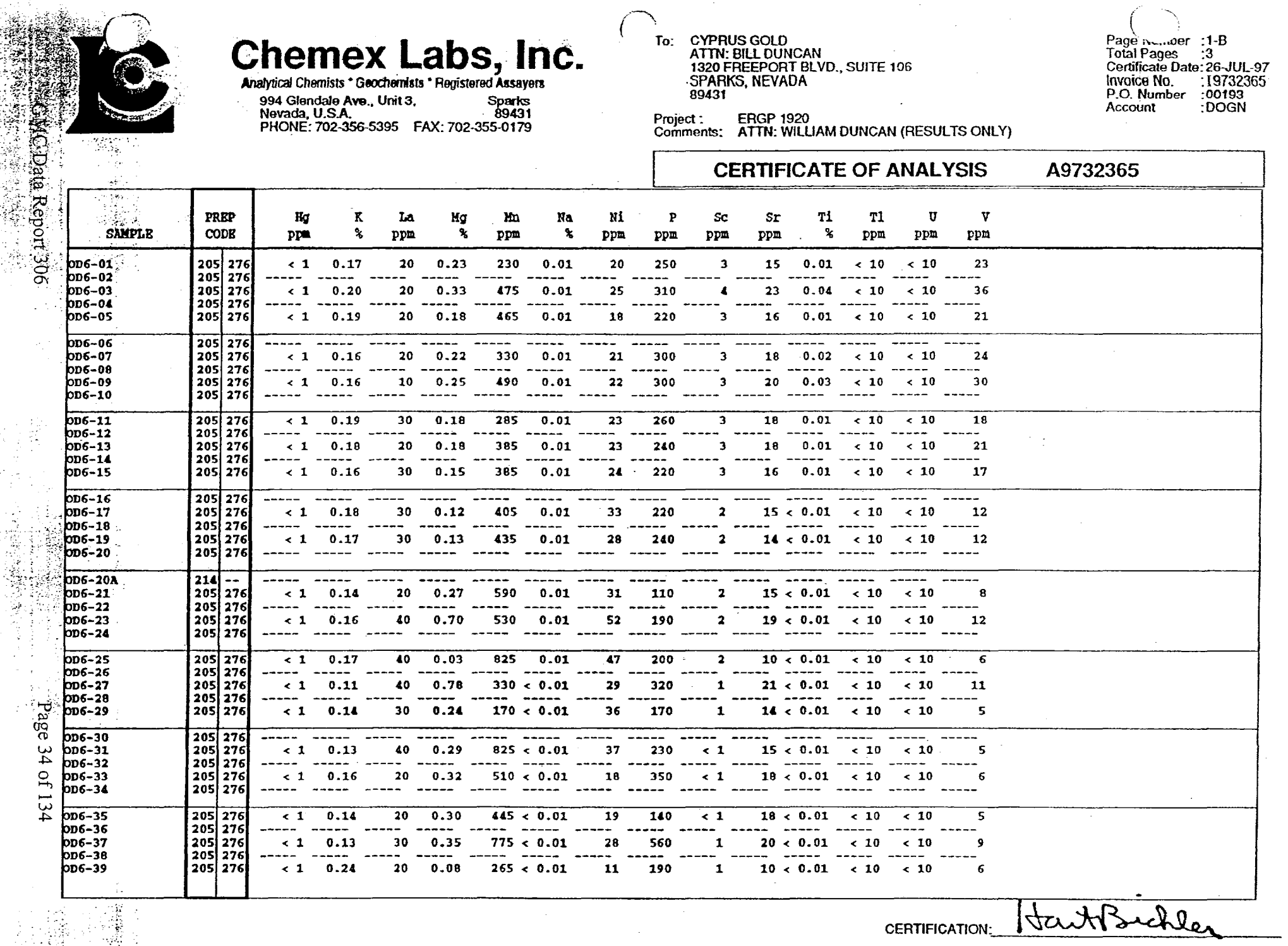




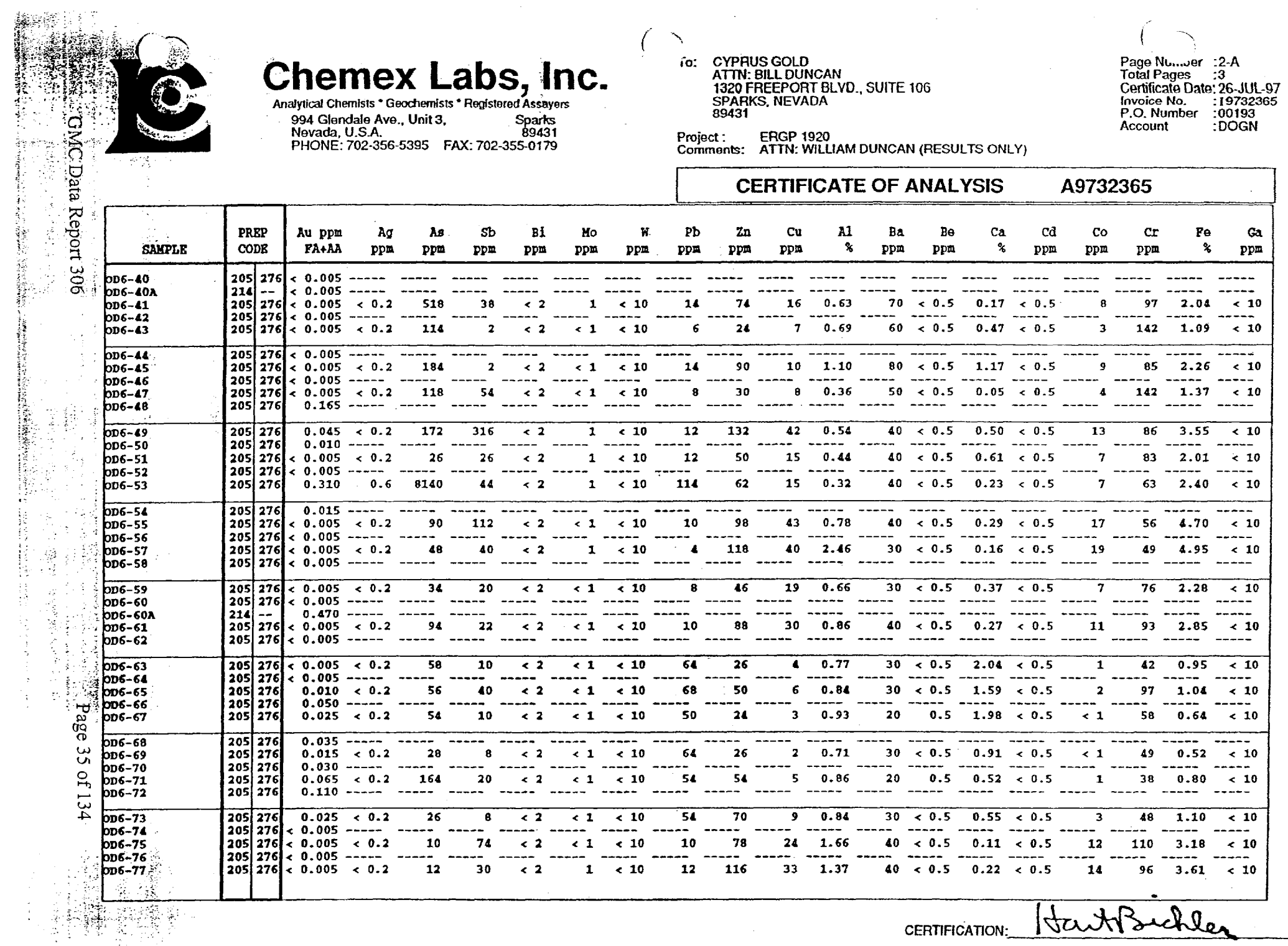




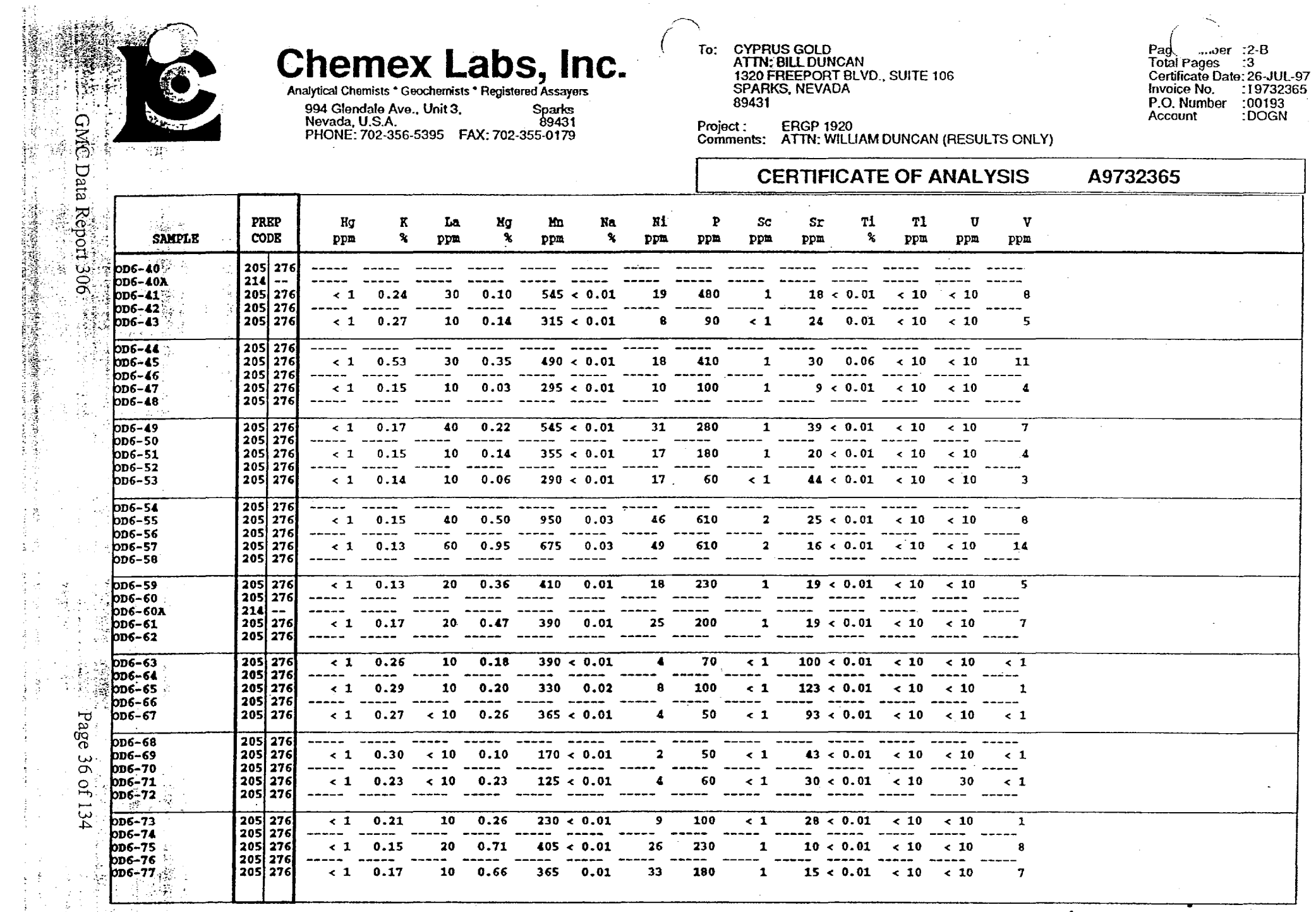




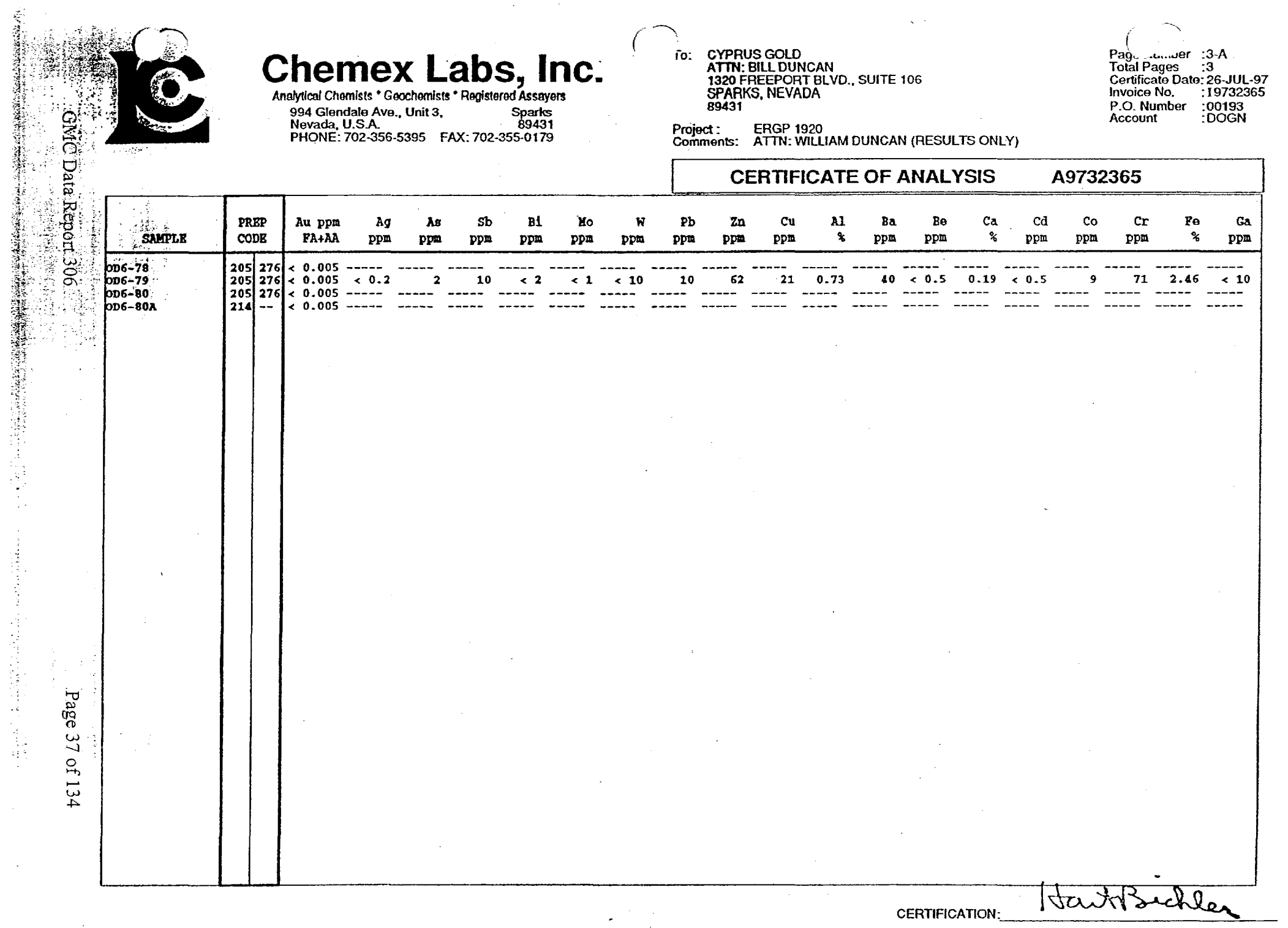




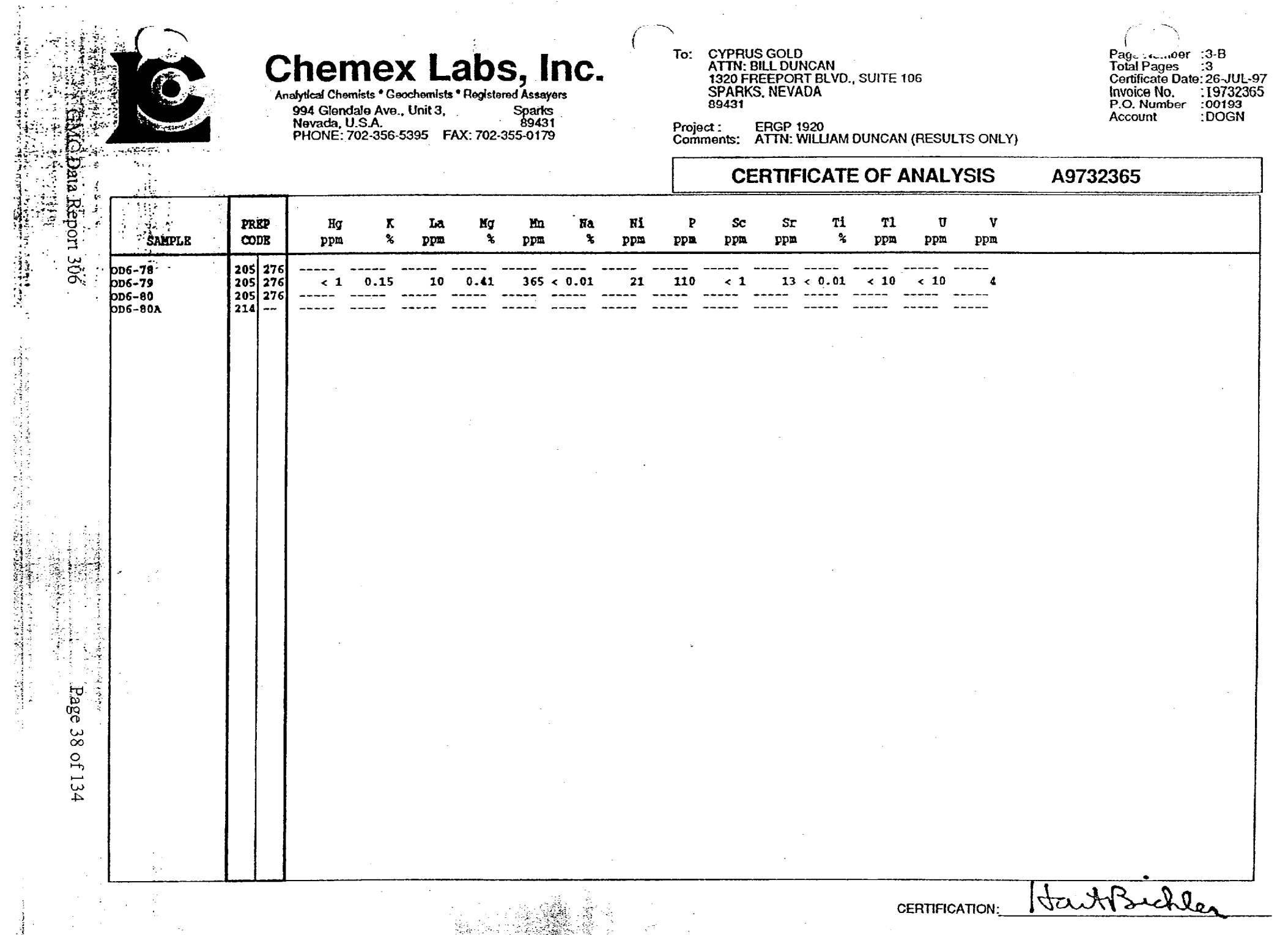




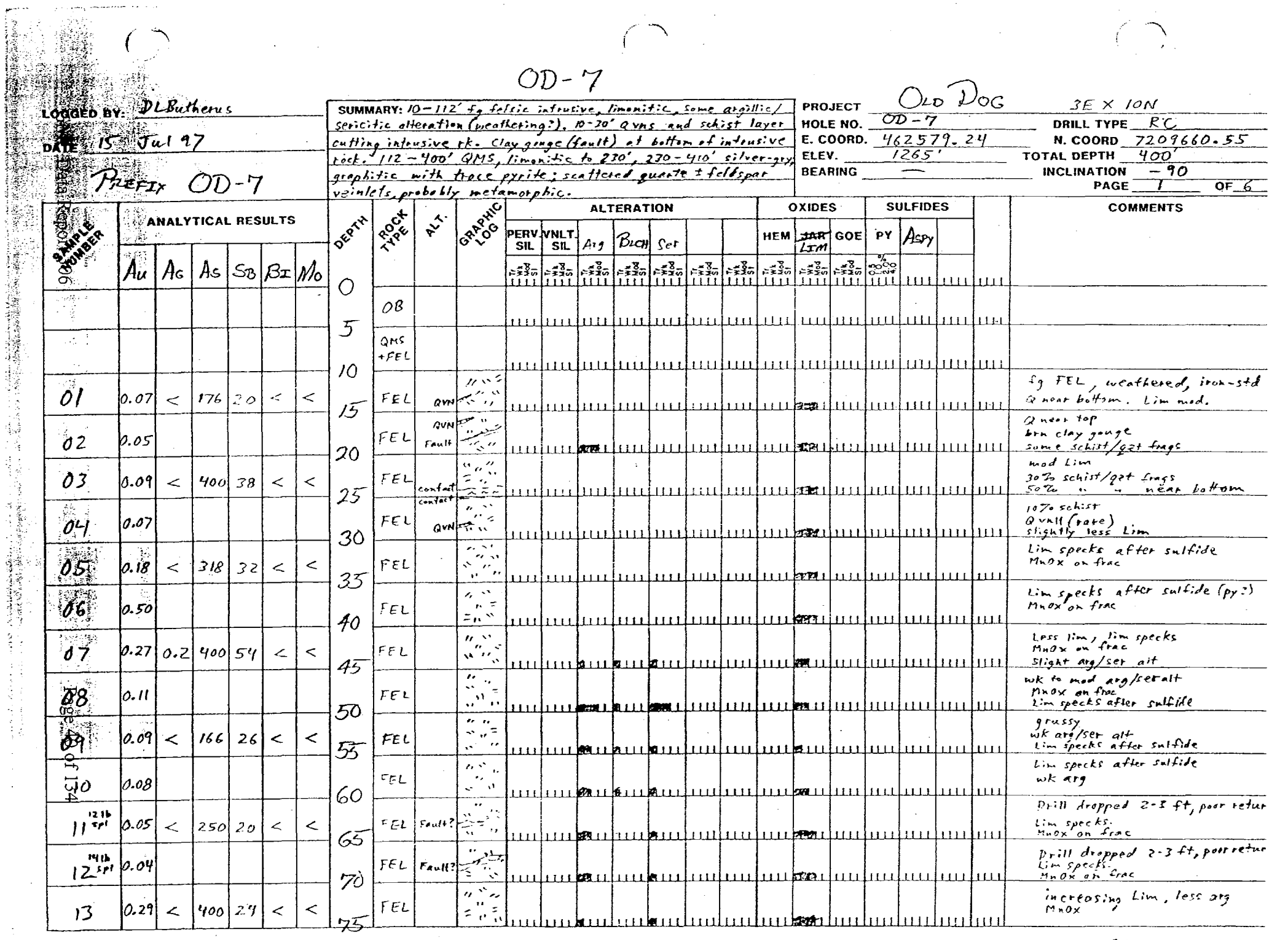




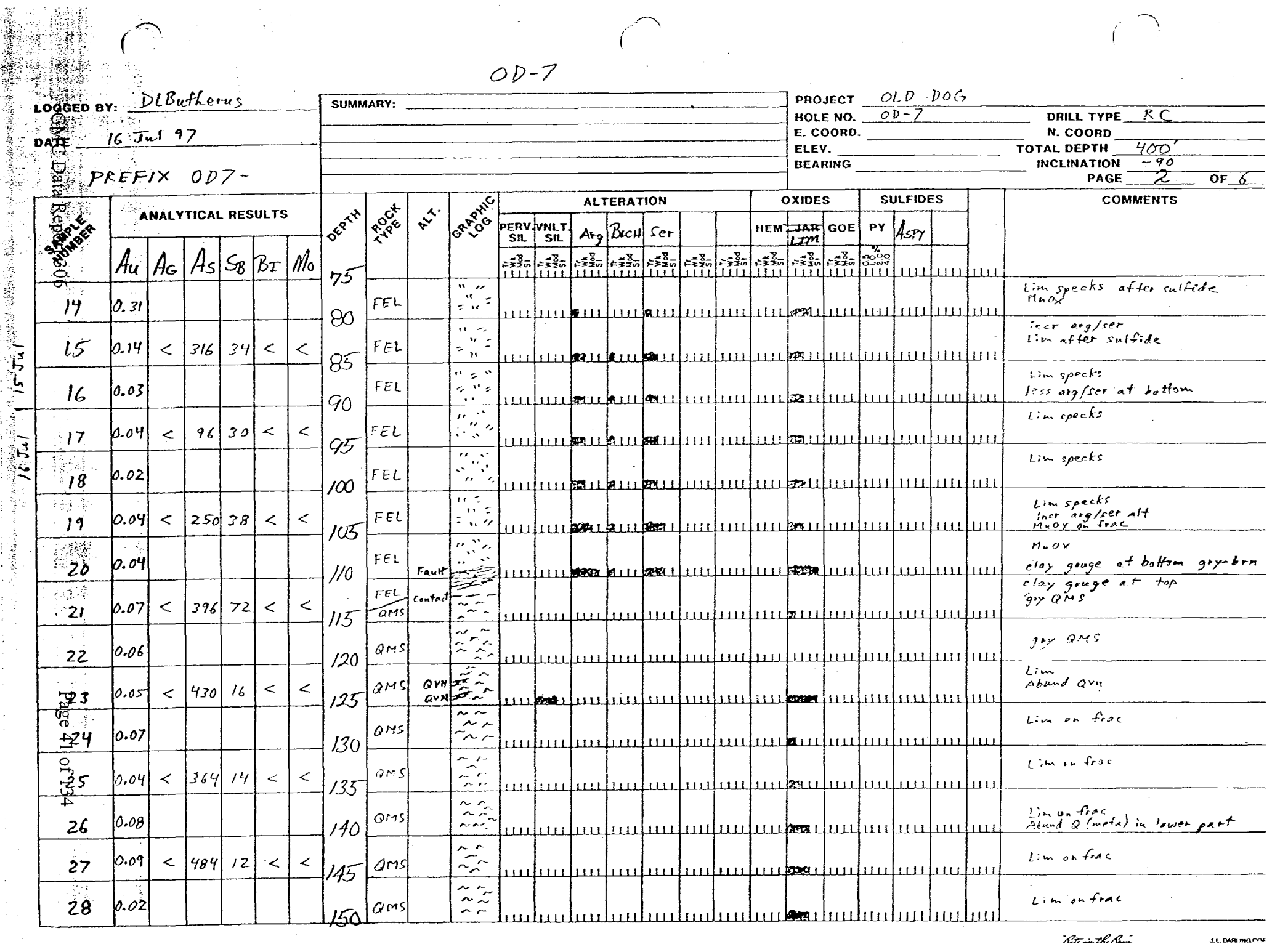




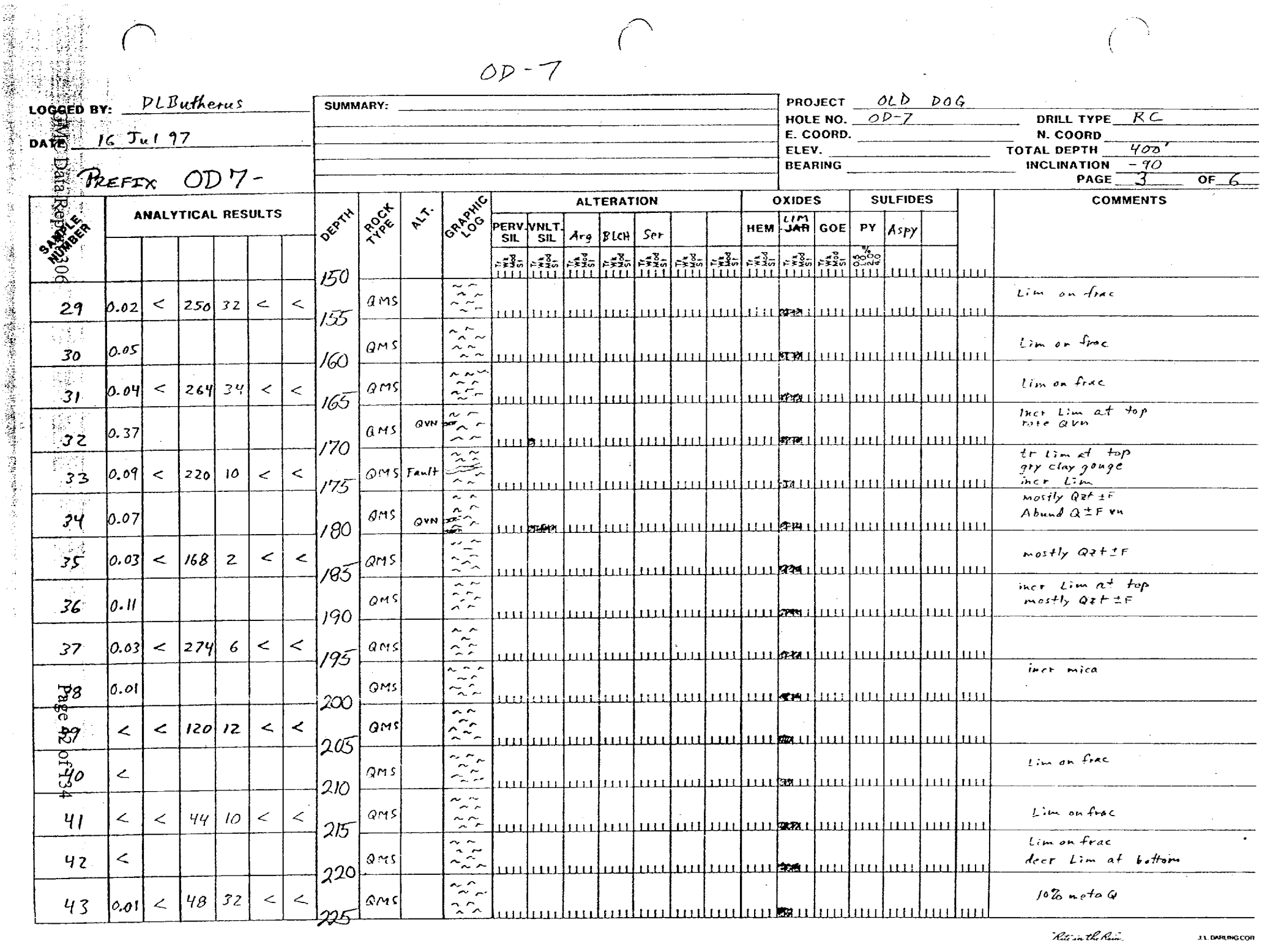




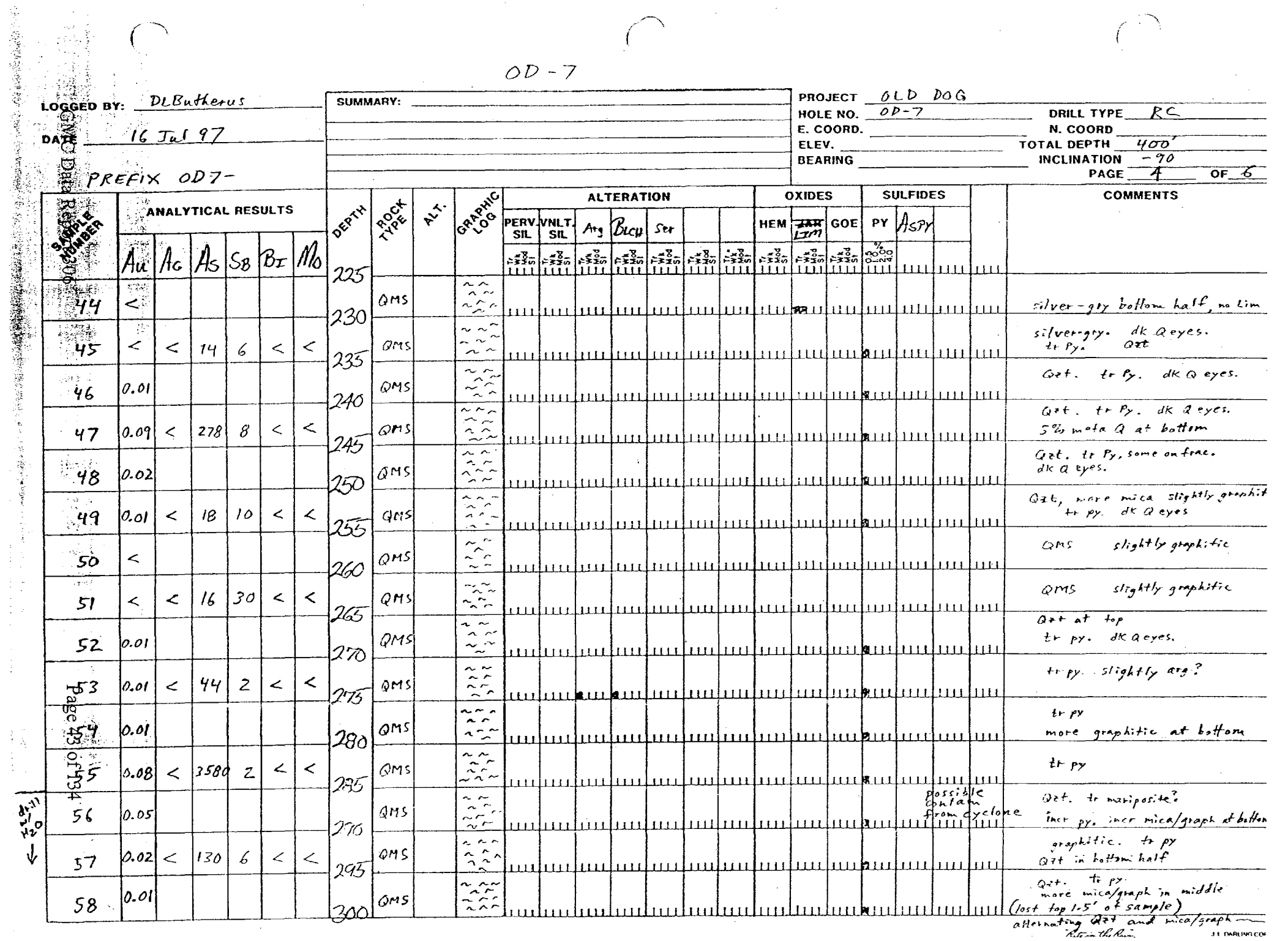




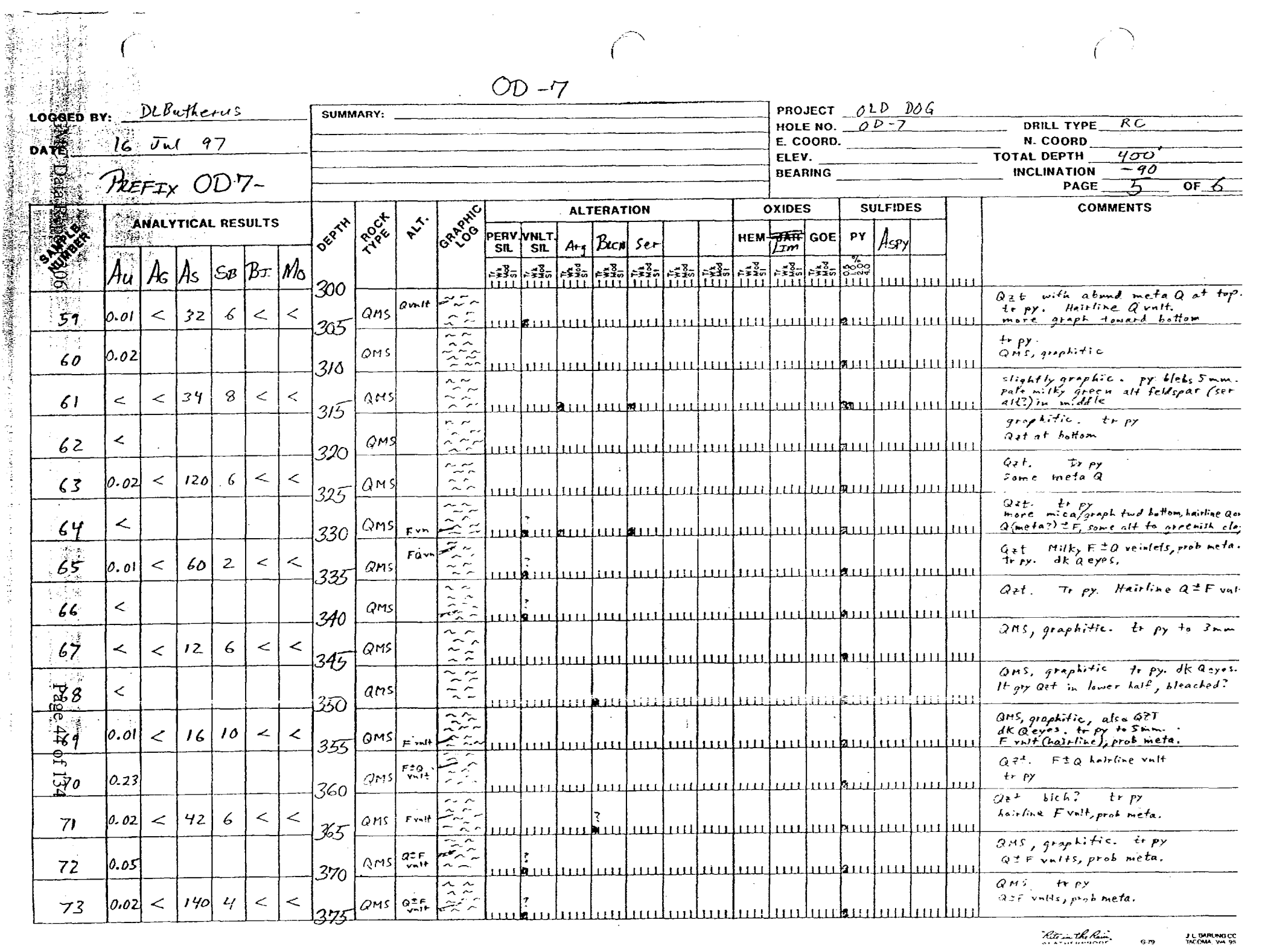




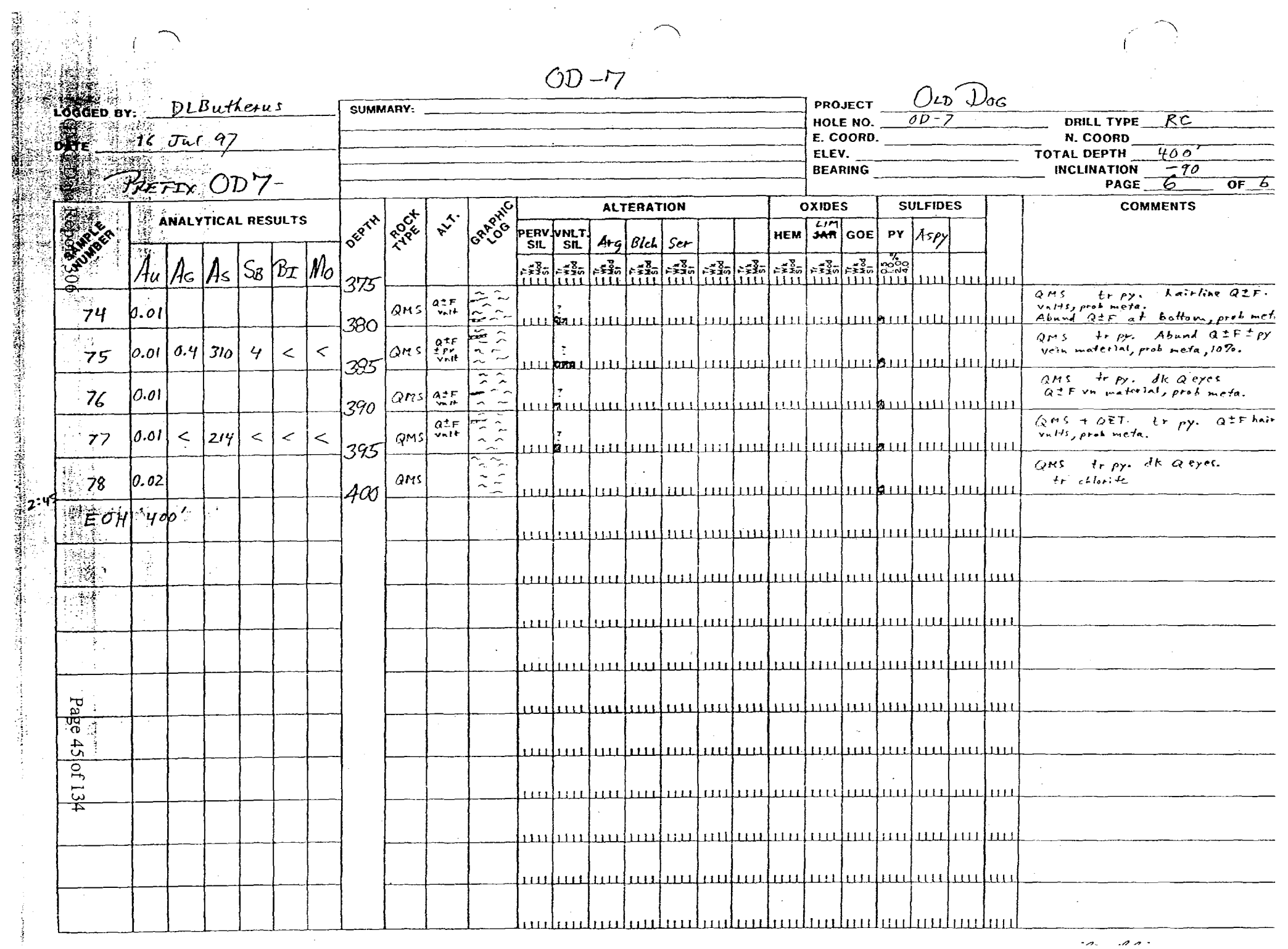




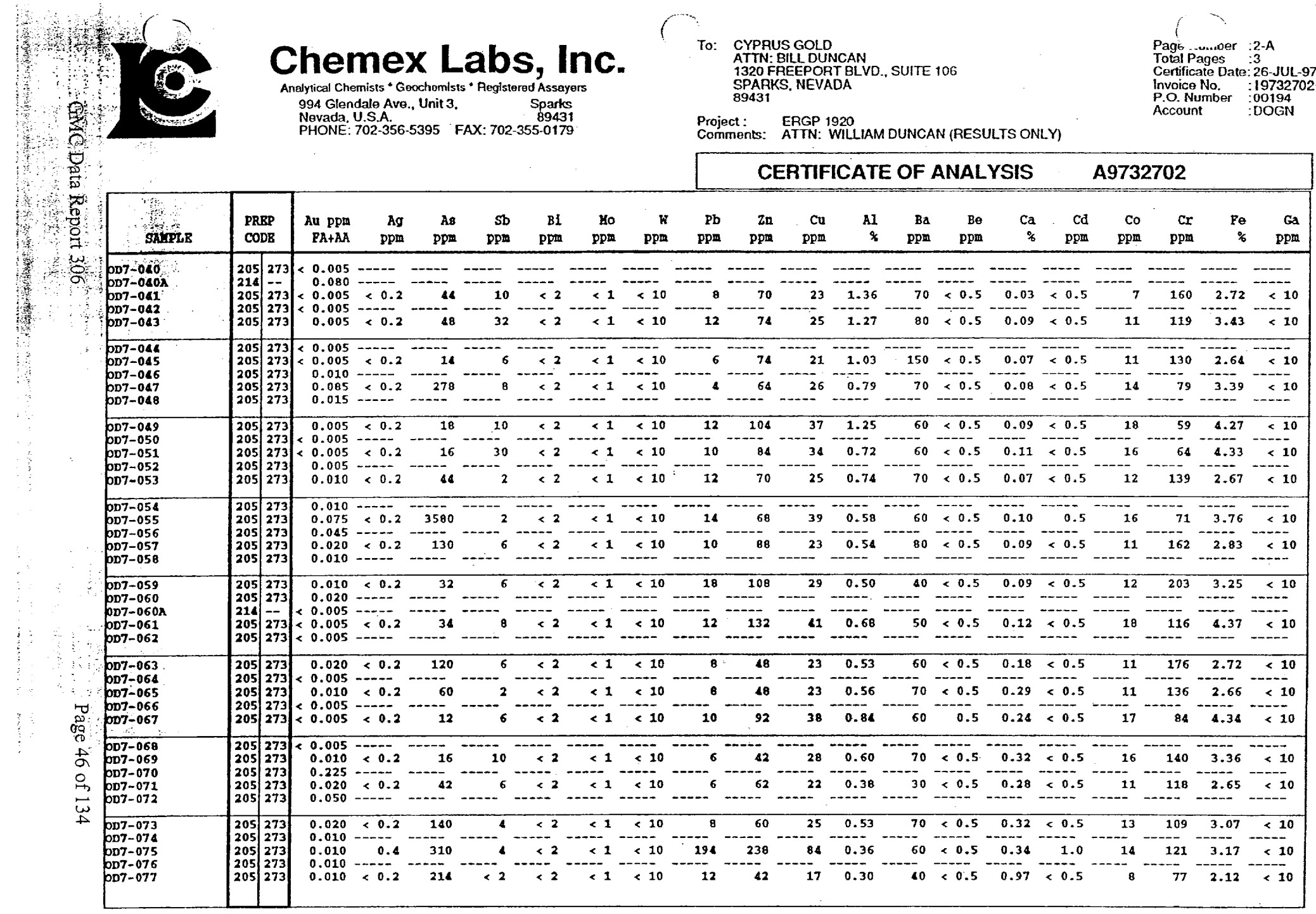




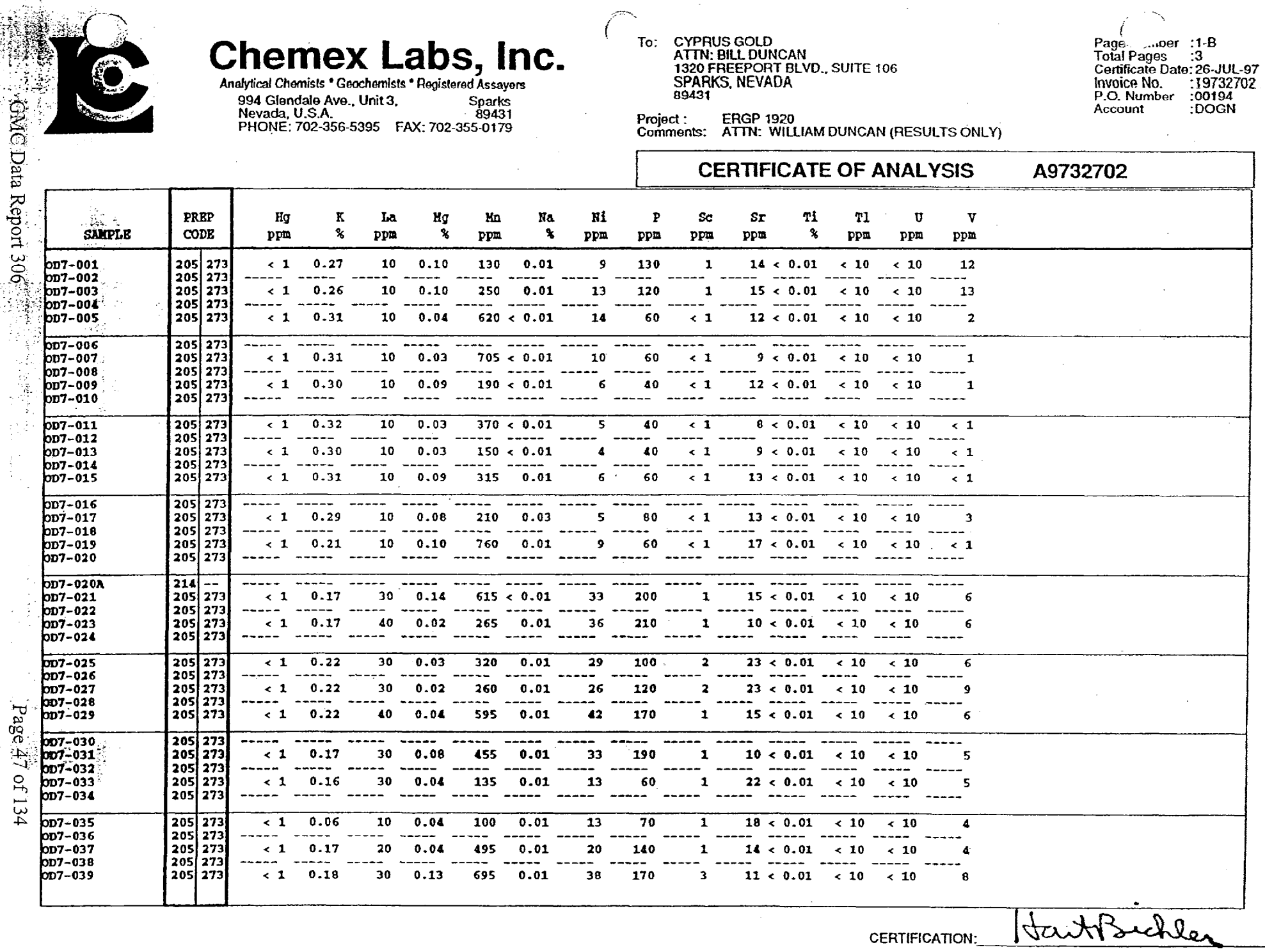


Chemex Labs, Inc.

Analytat Chemists * Geochemists " Registered Assayers 994 Gindise Ave., Unit 3.

Nevade, U.S.A. Sparks

PHONE: 702-356-5395 FAX: 702-355-0179
To: CYPRUS GOLD

ATM: BILL DUNCAN

FEEPOAT BLVD.. SUITE 106 SPAPS NEVADA B9431

Project: ERGP 1920

Comments: ATTN: WILLIAM DUNCAN (RESULTS ONLY)
Pags

Certificate Date: 26 -JUL-97 Invoice No: : 19732702 P.O. Number :00194 $\begin{array}{ll}\text { Account } & \text { :DOGN }\end{array}$

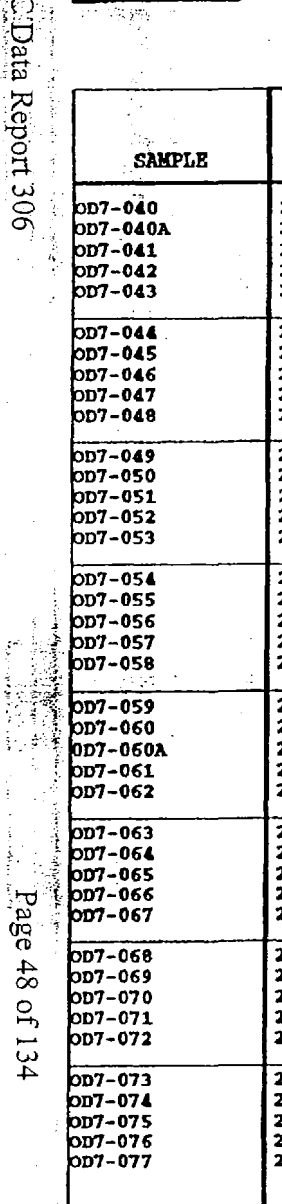

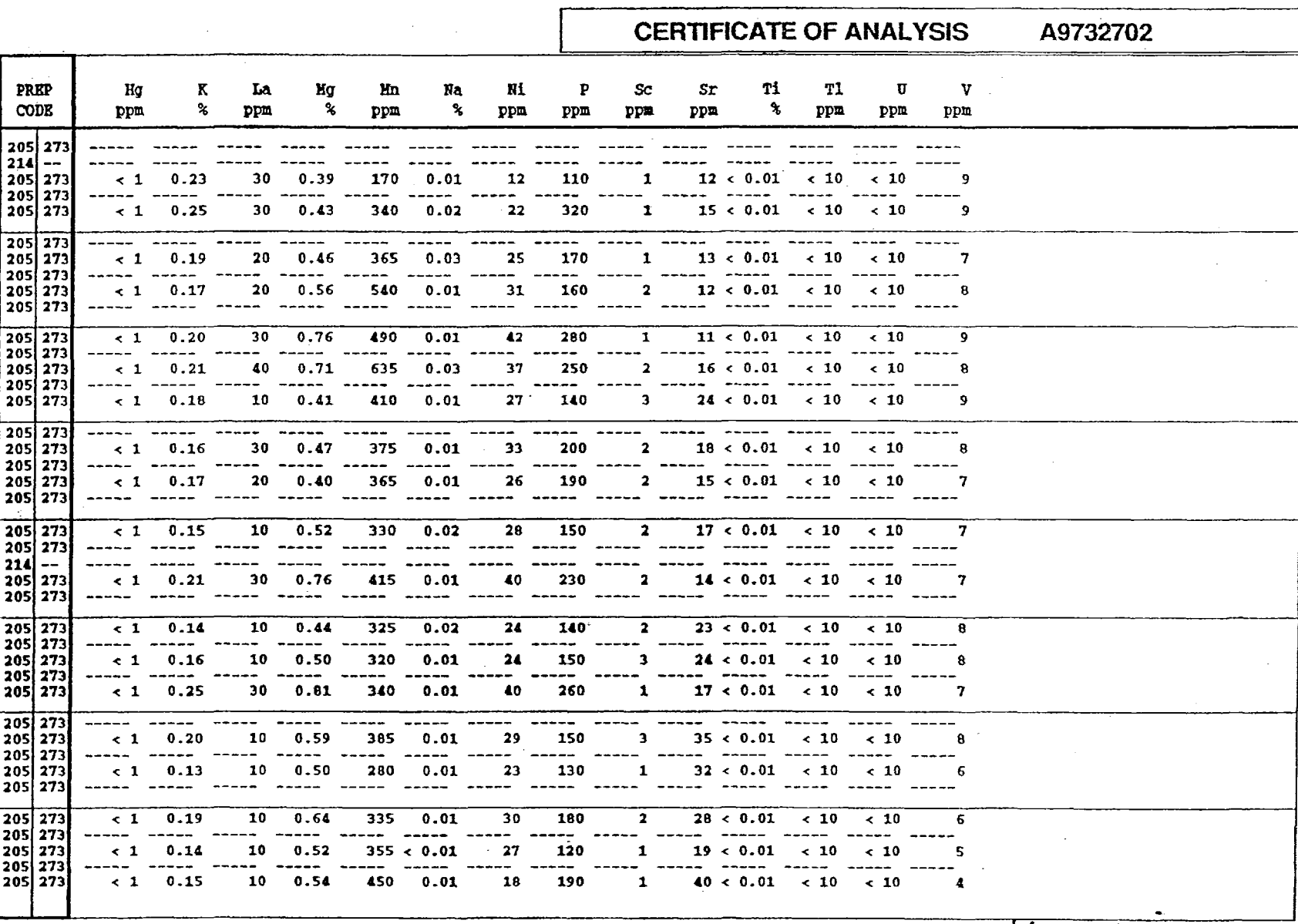




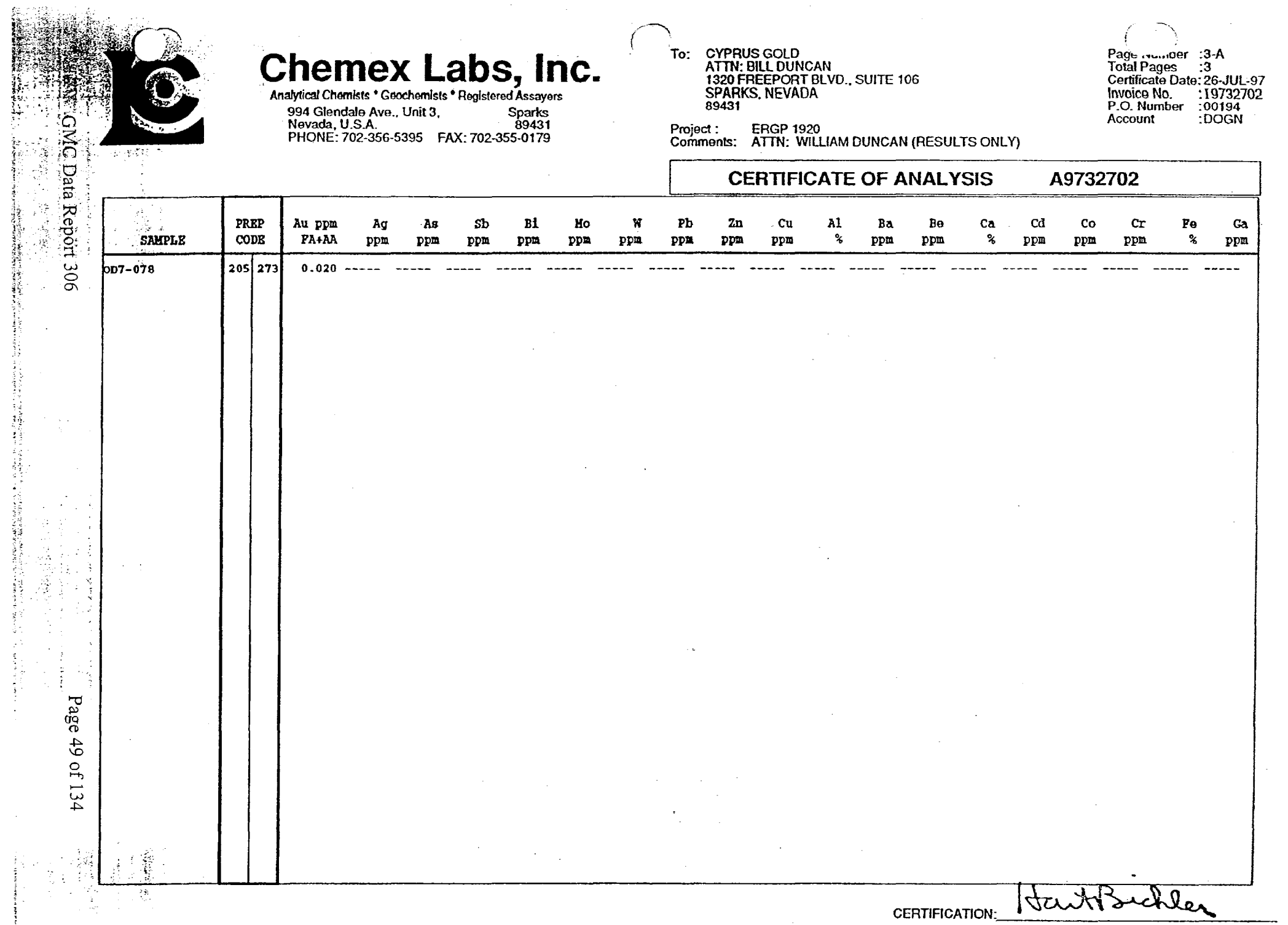




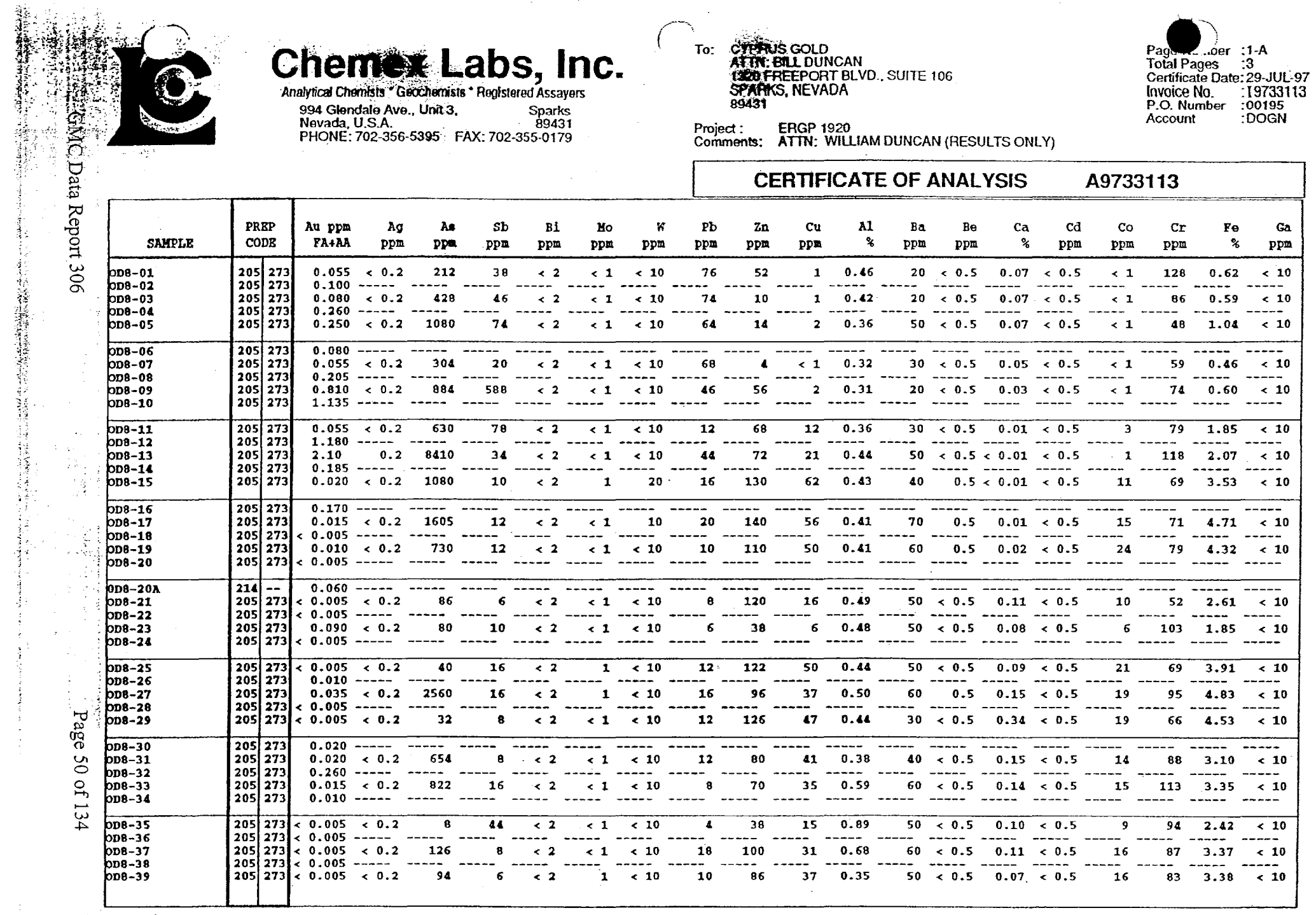




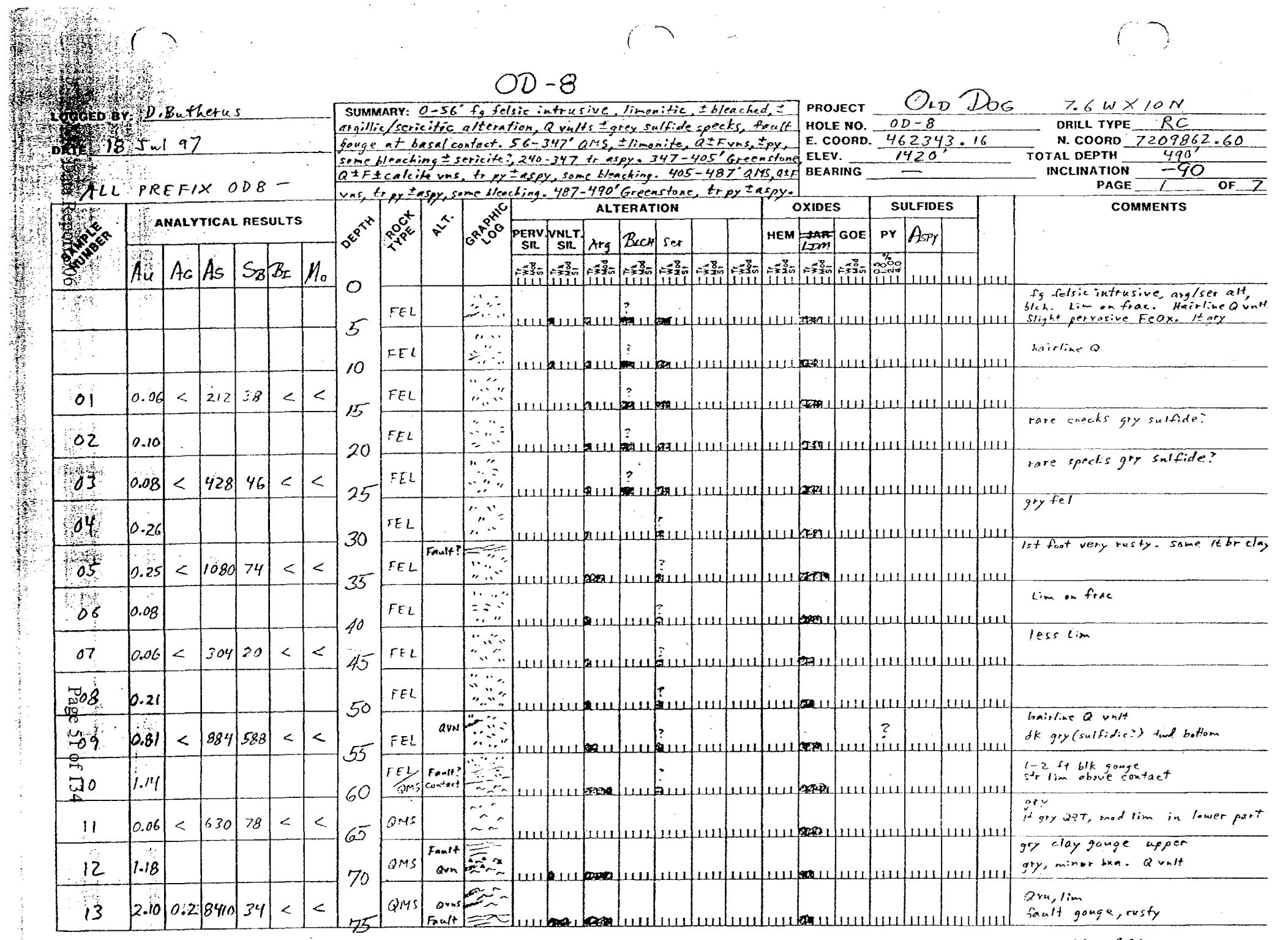




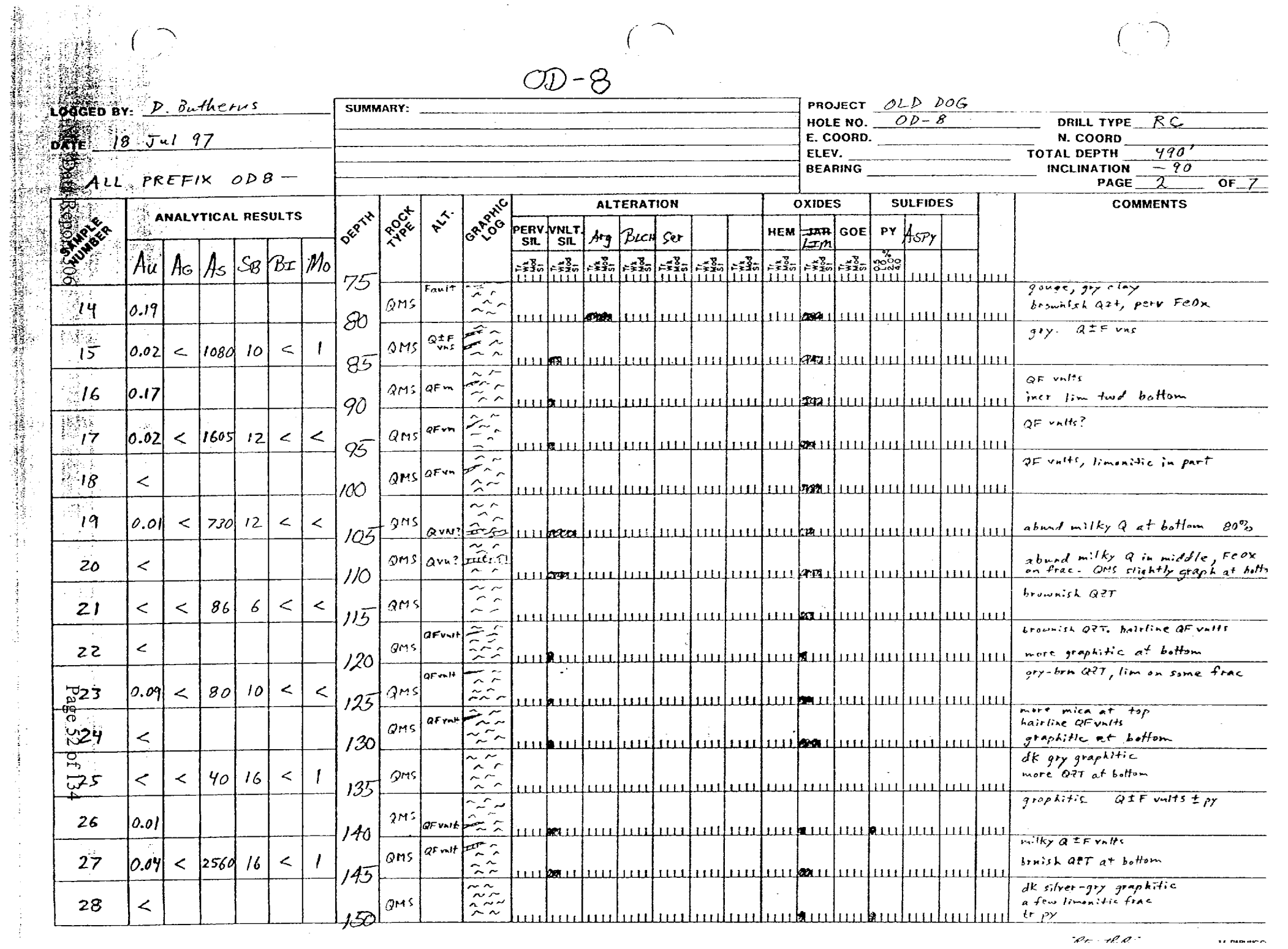




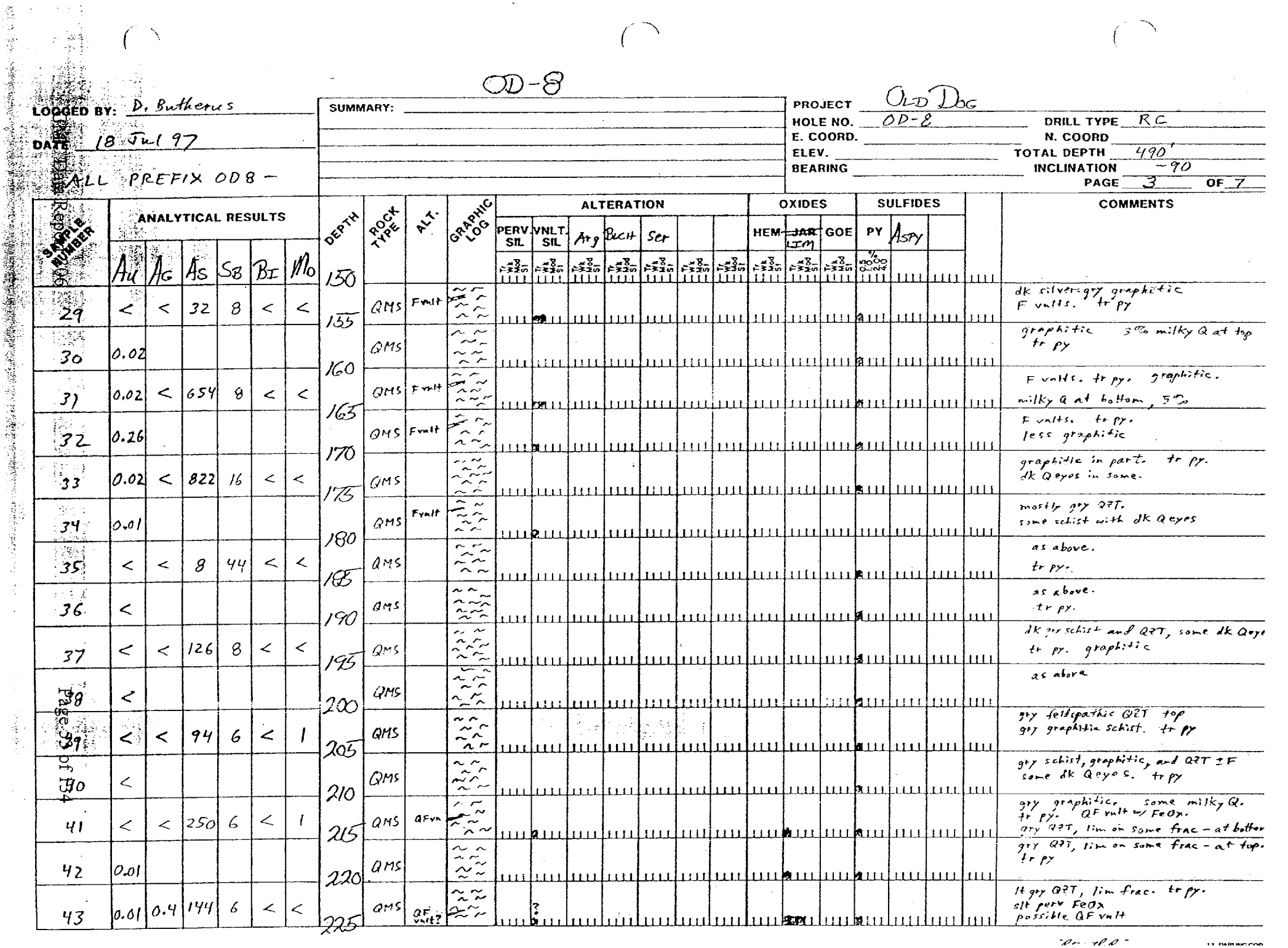




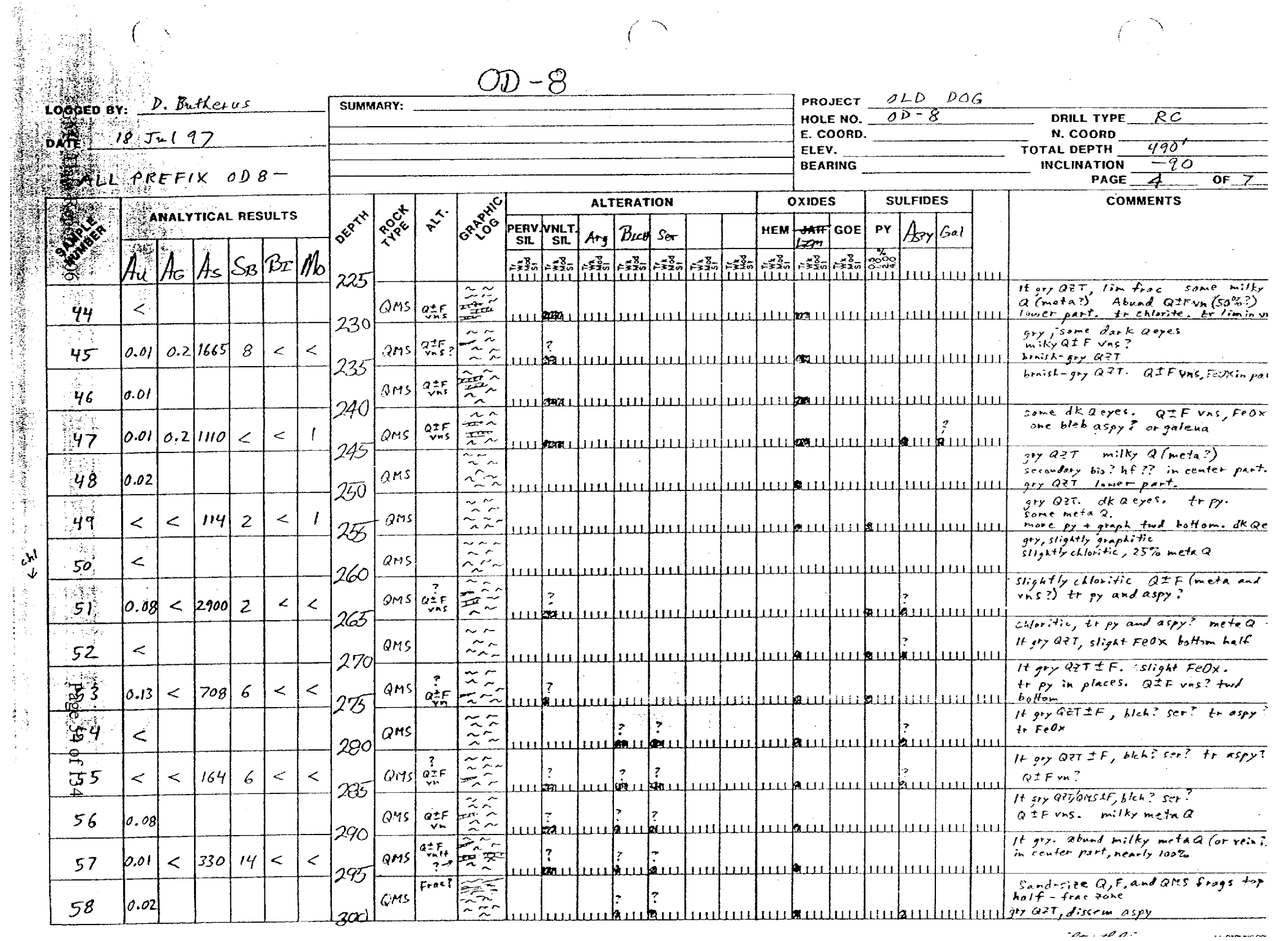




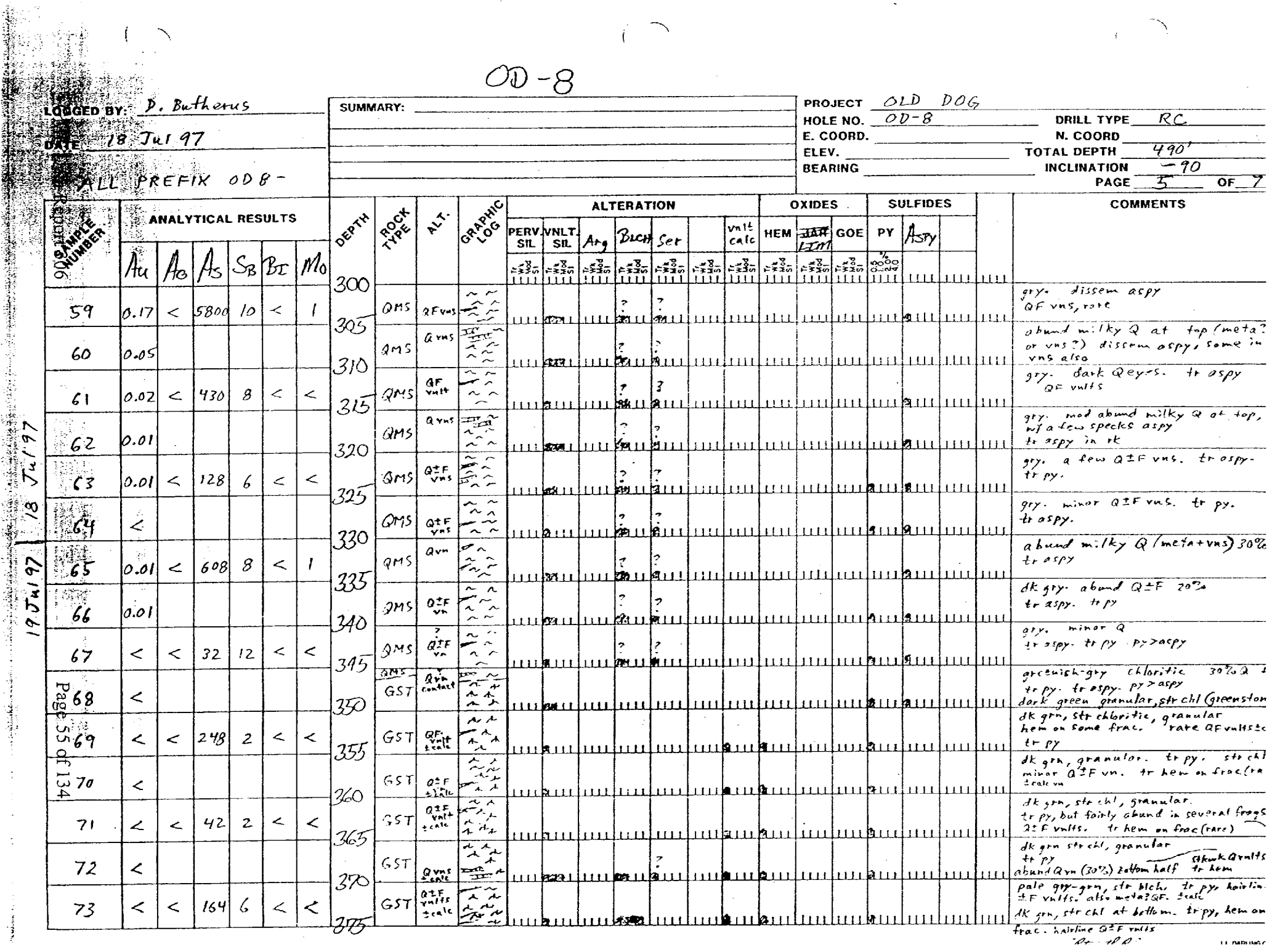




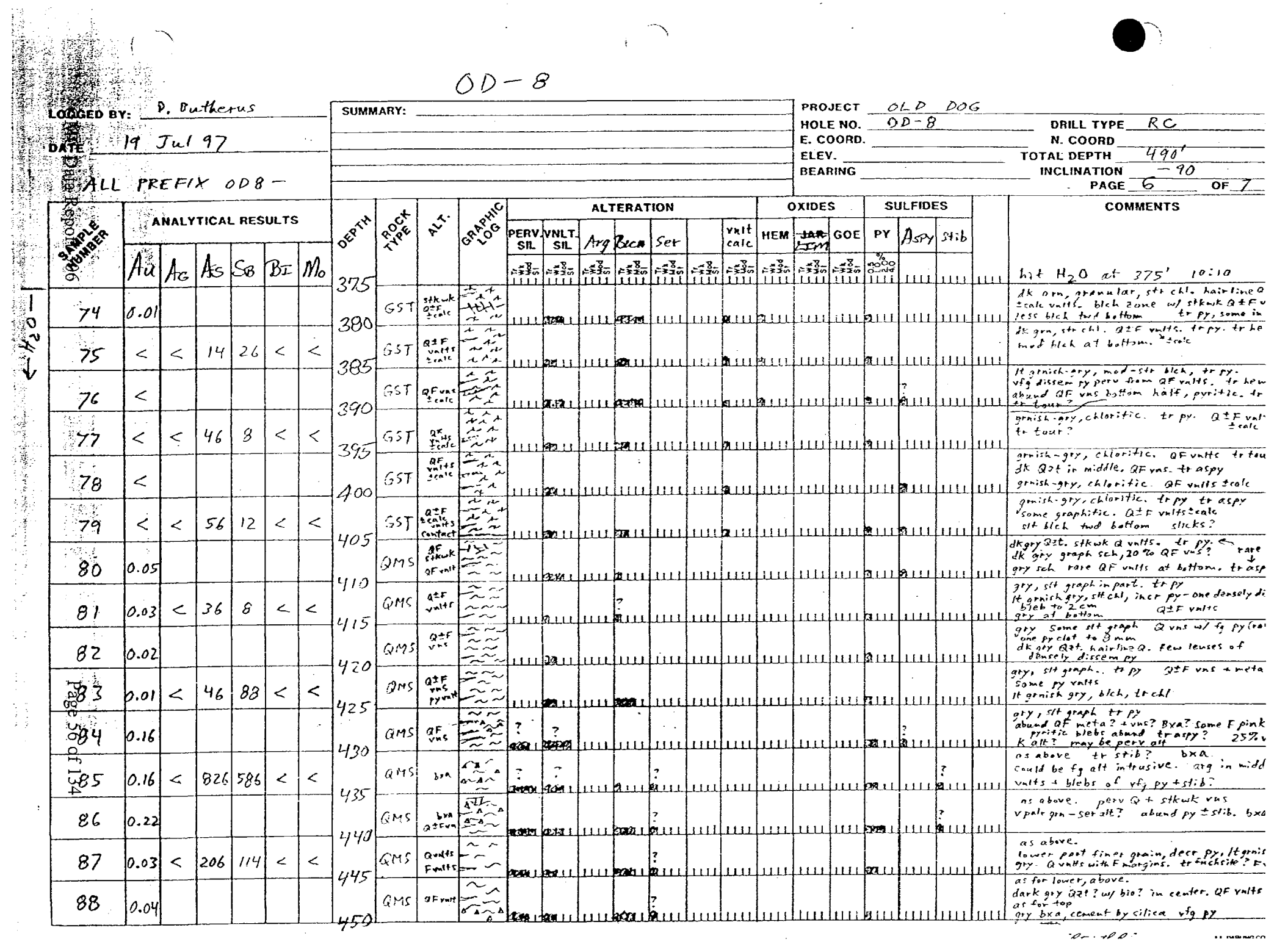




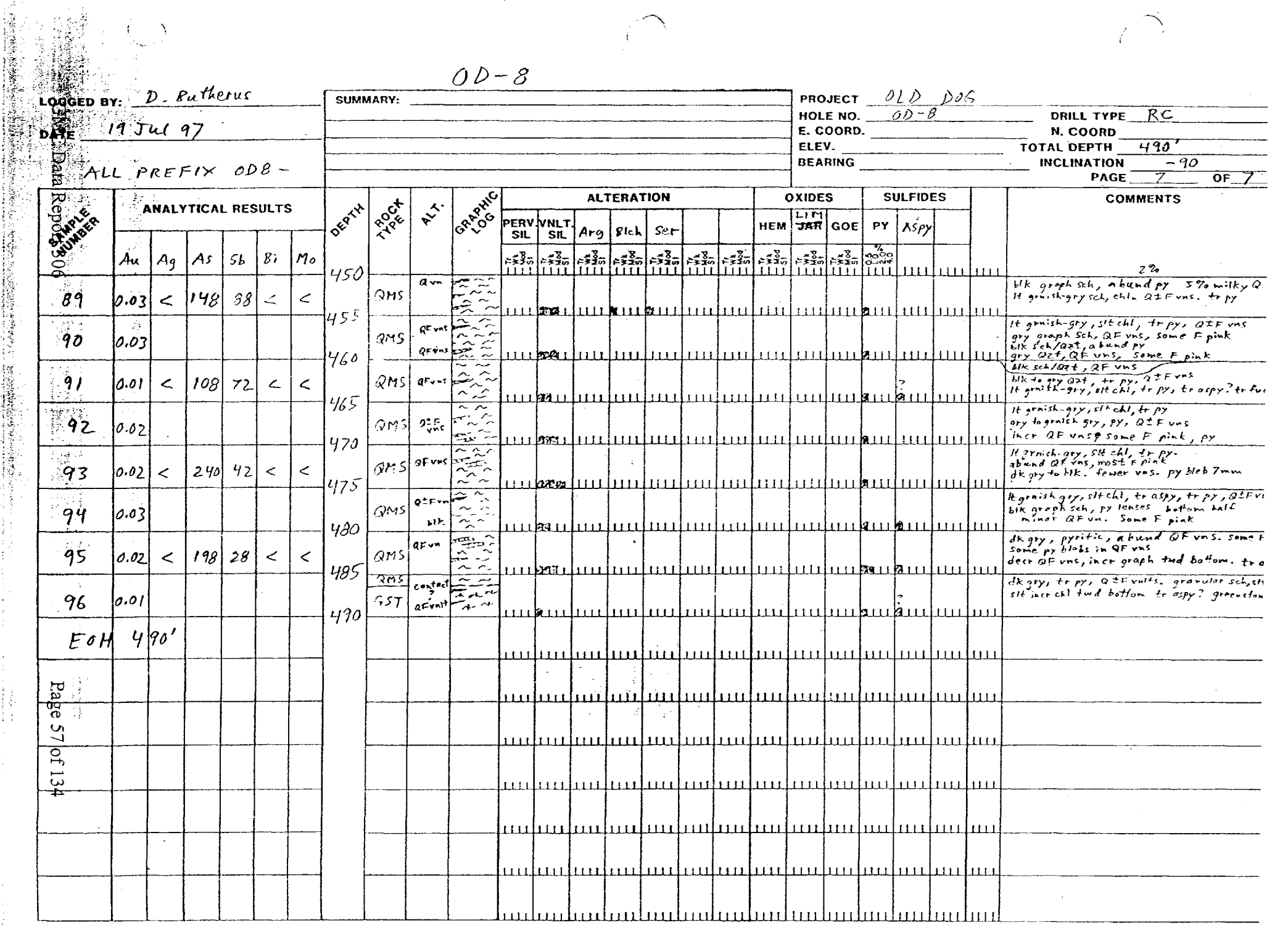

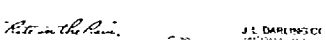




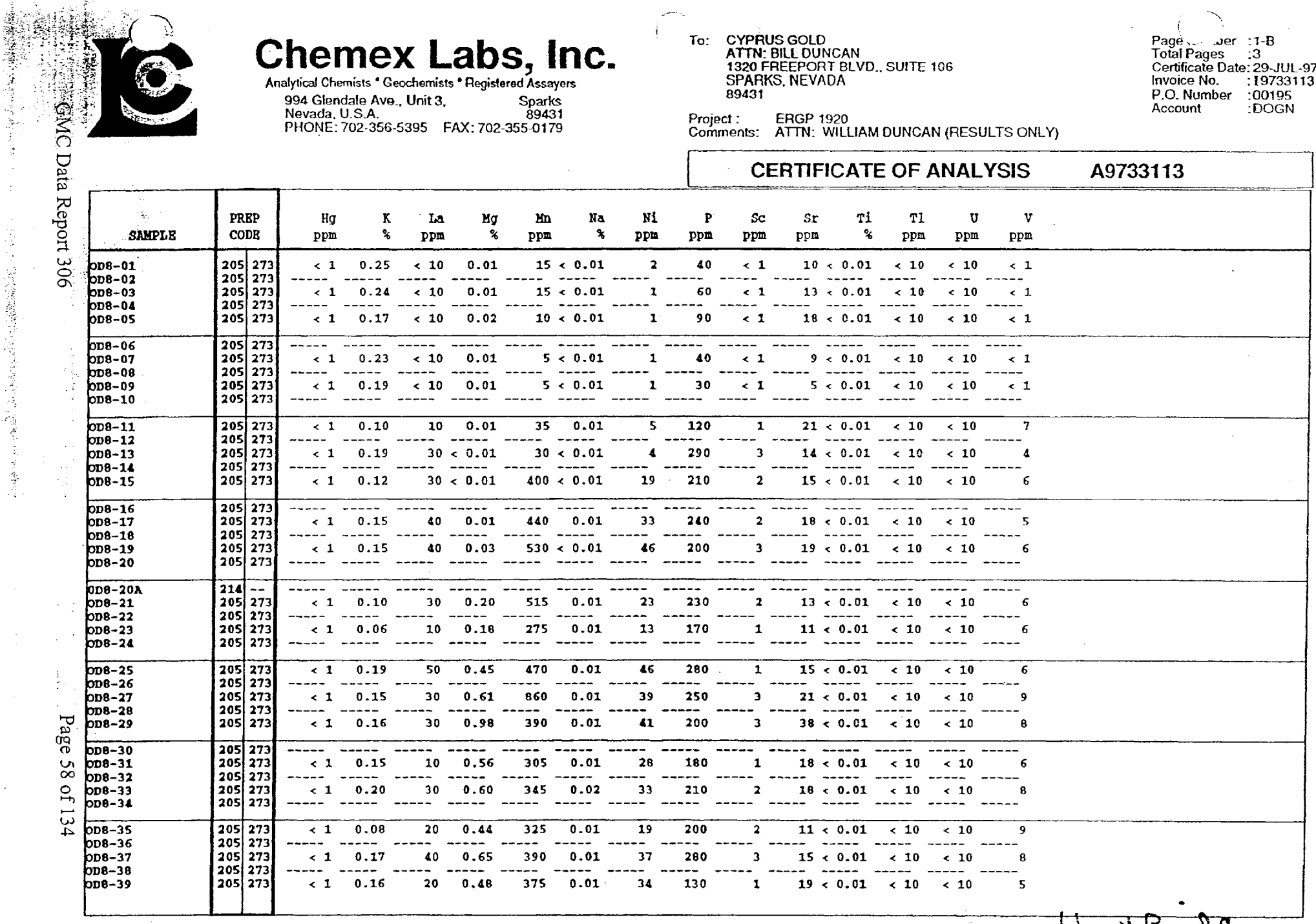




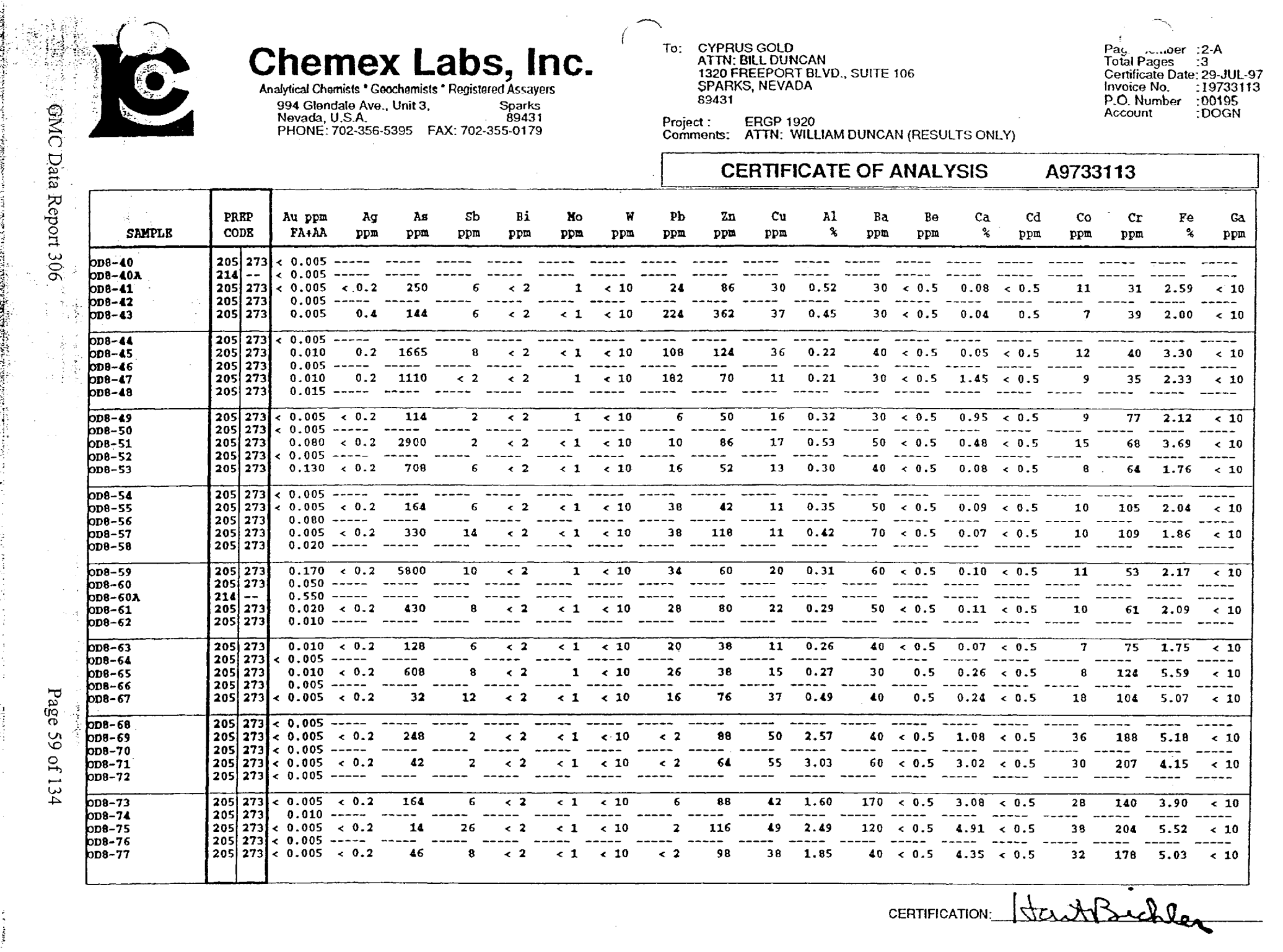




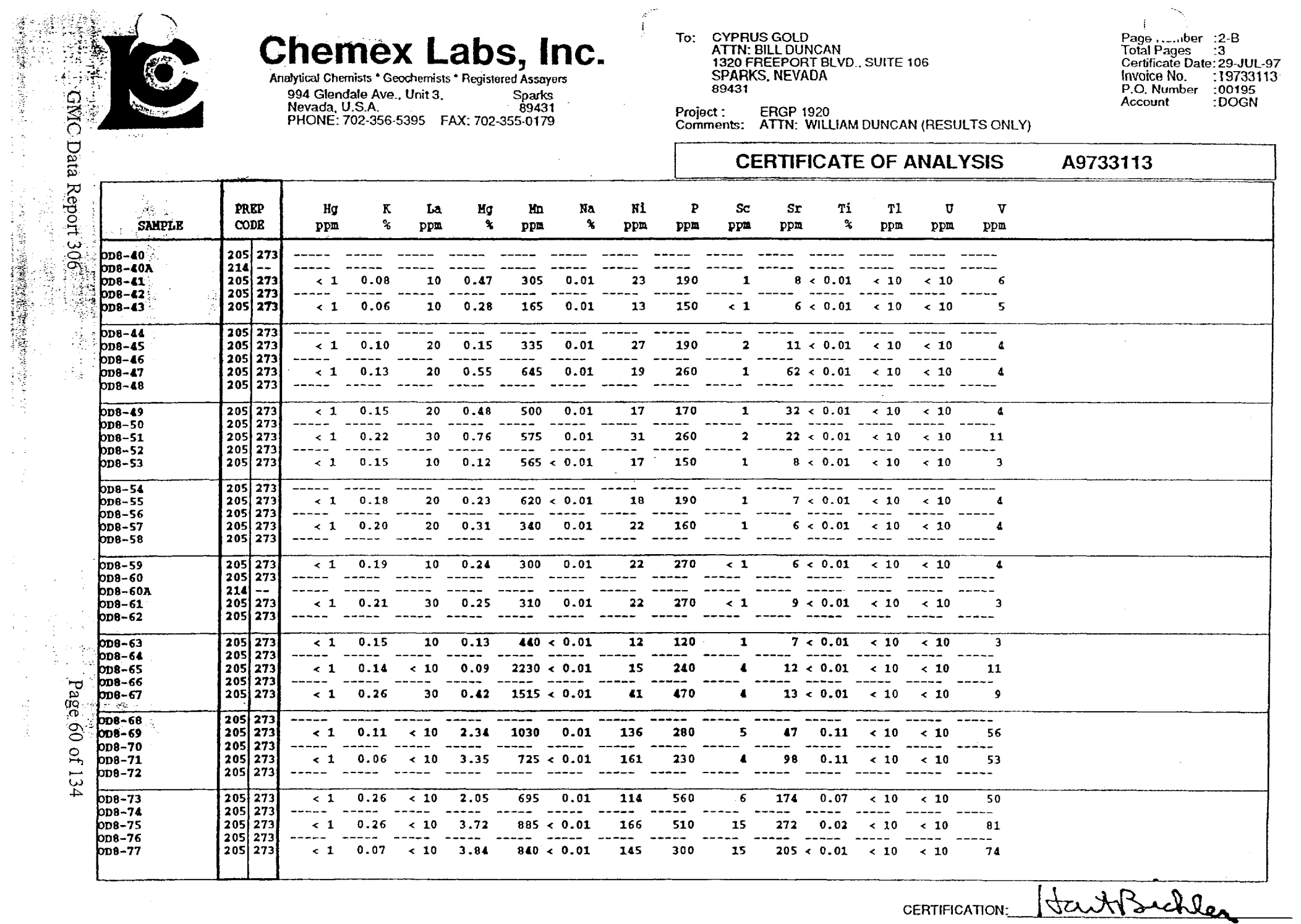




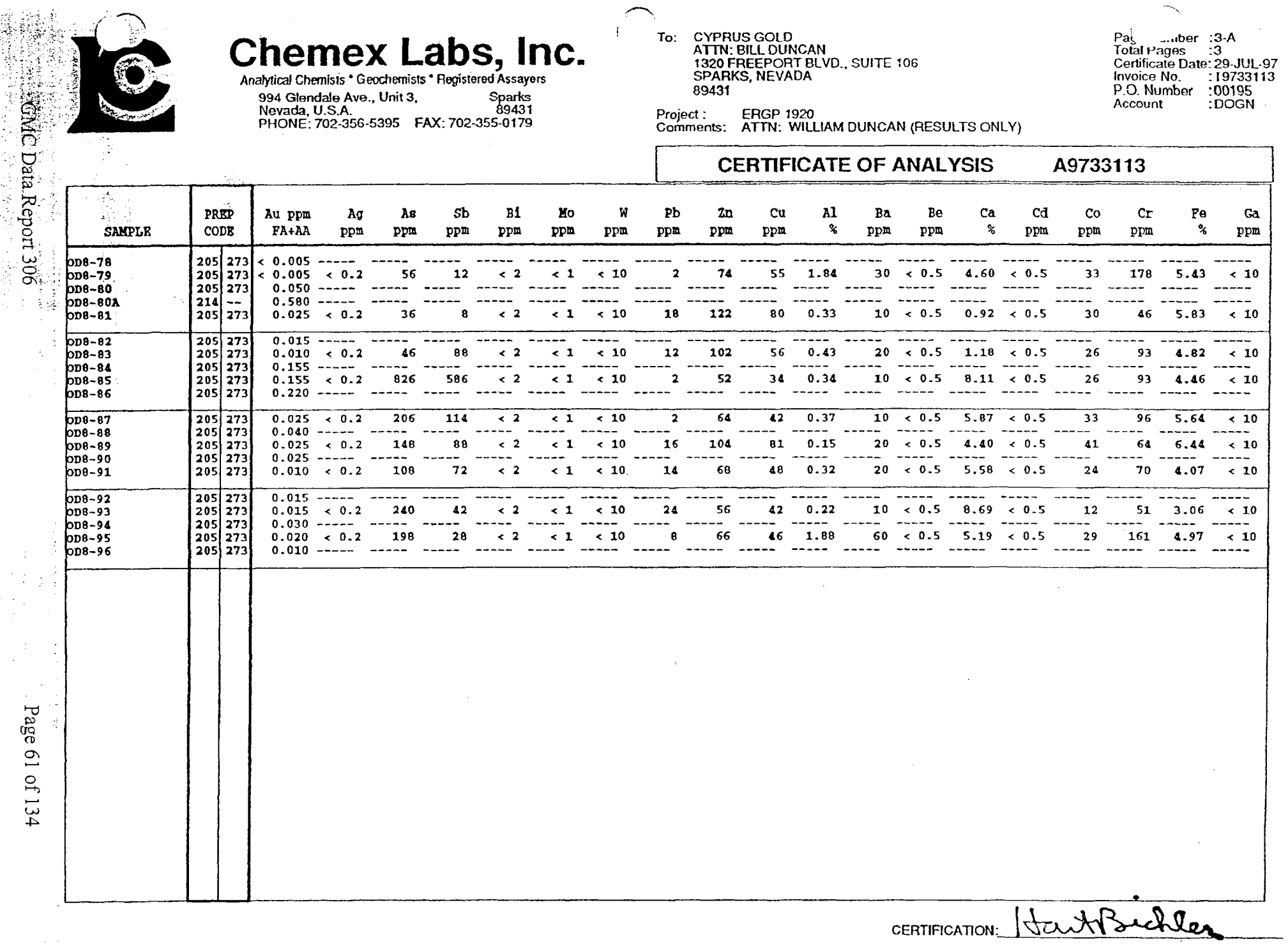




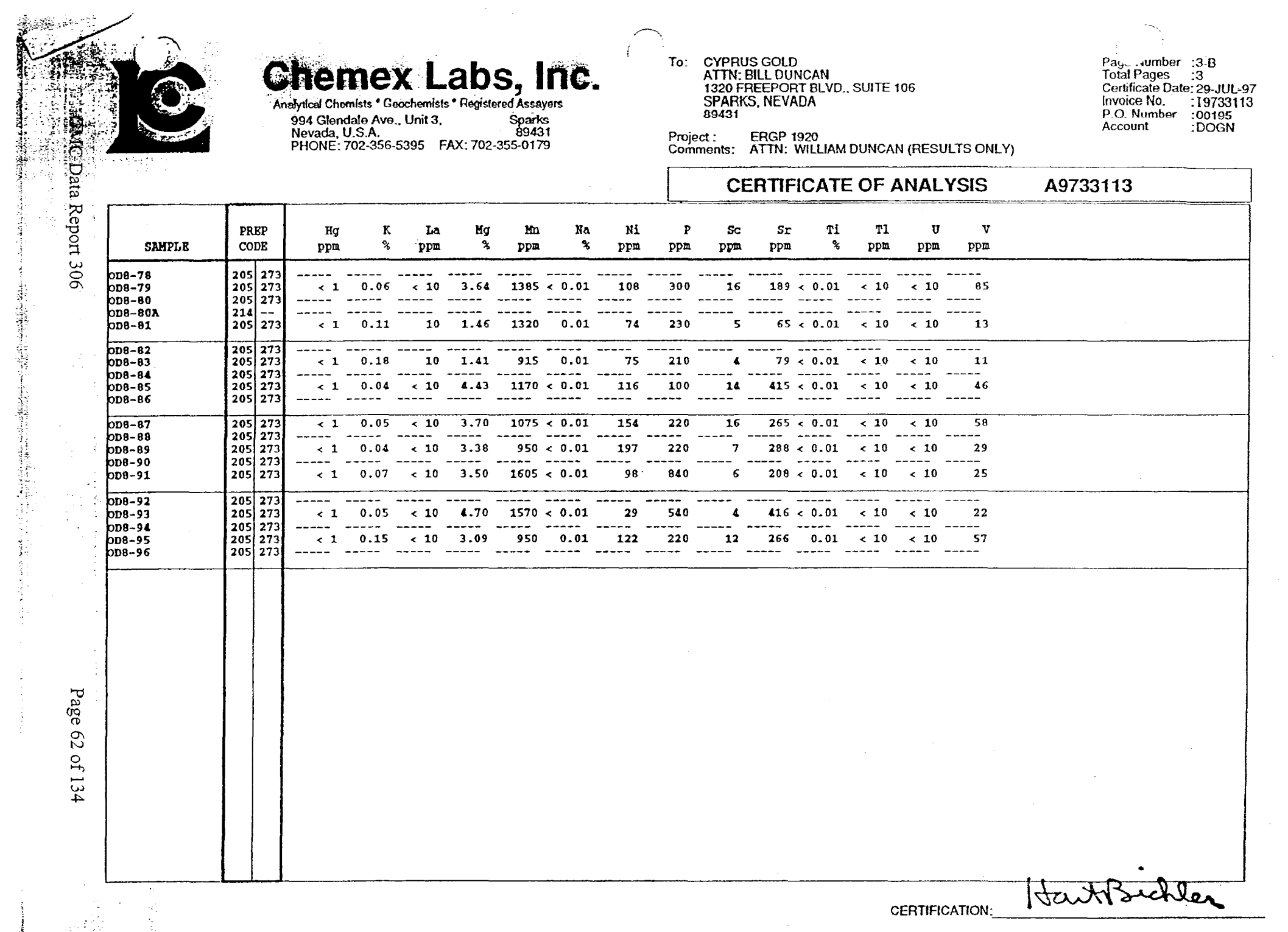




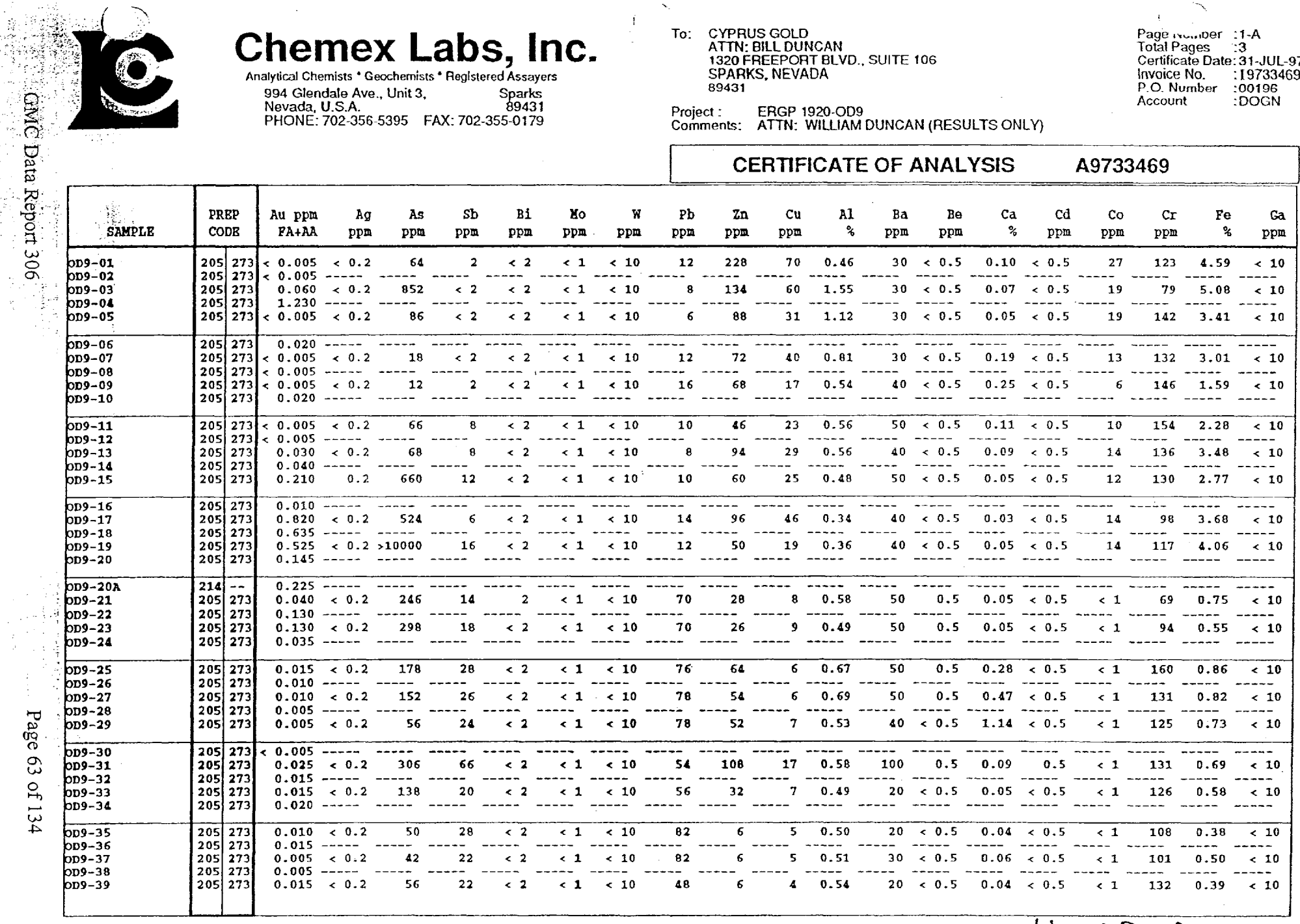




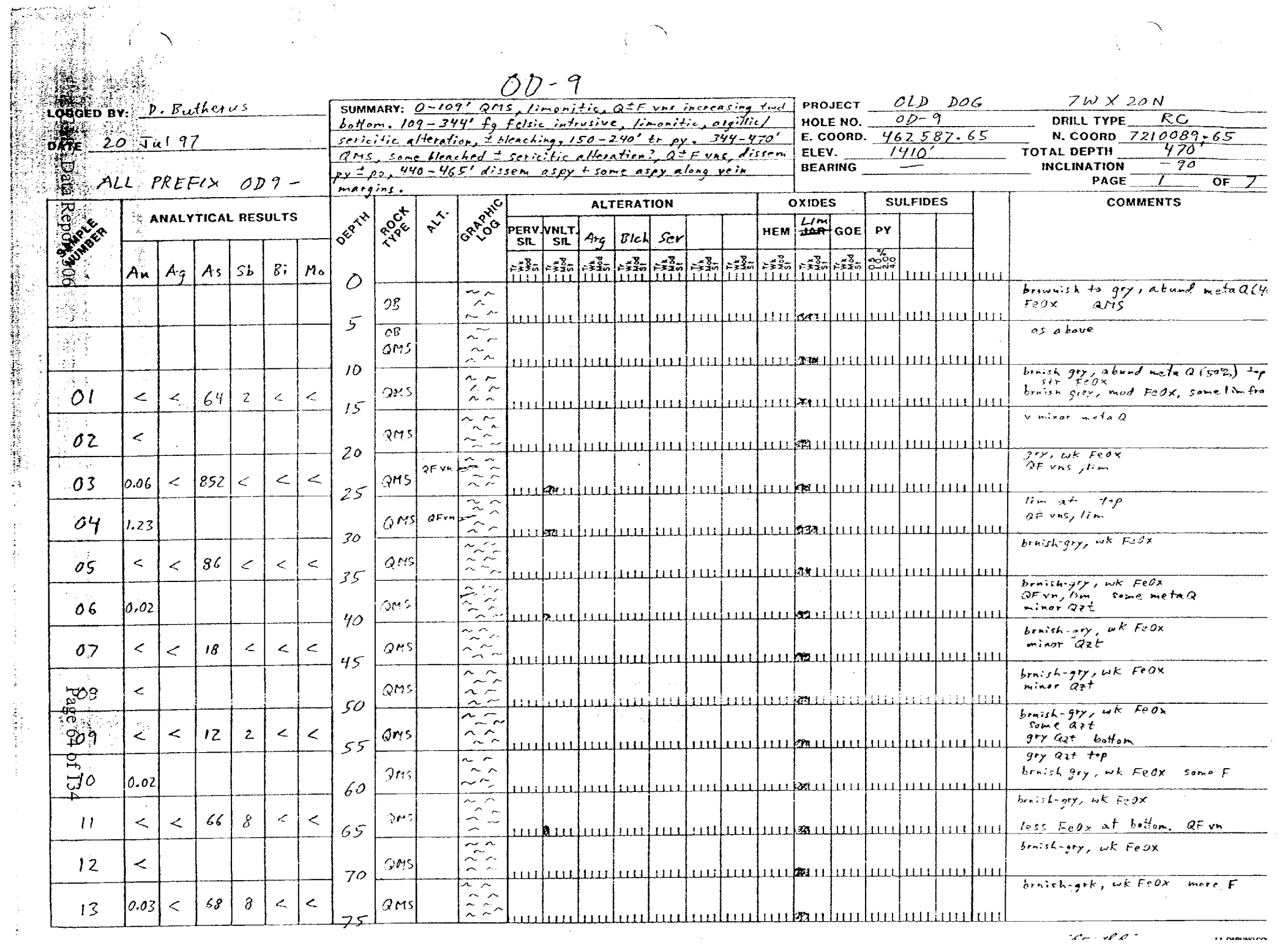




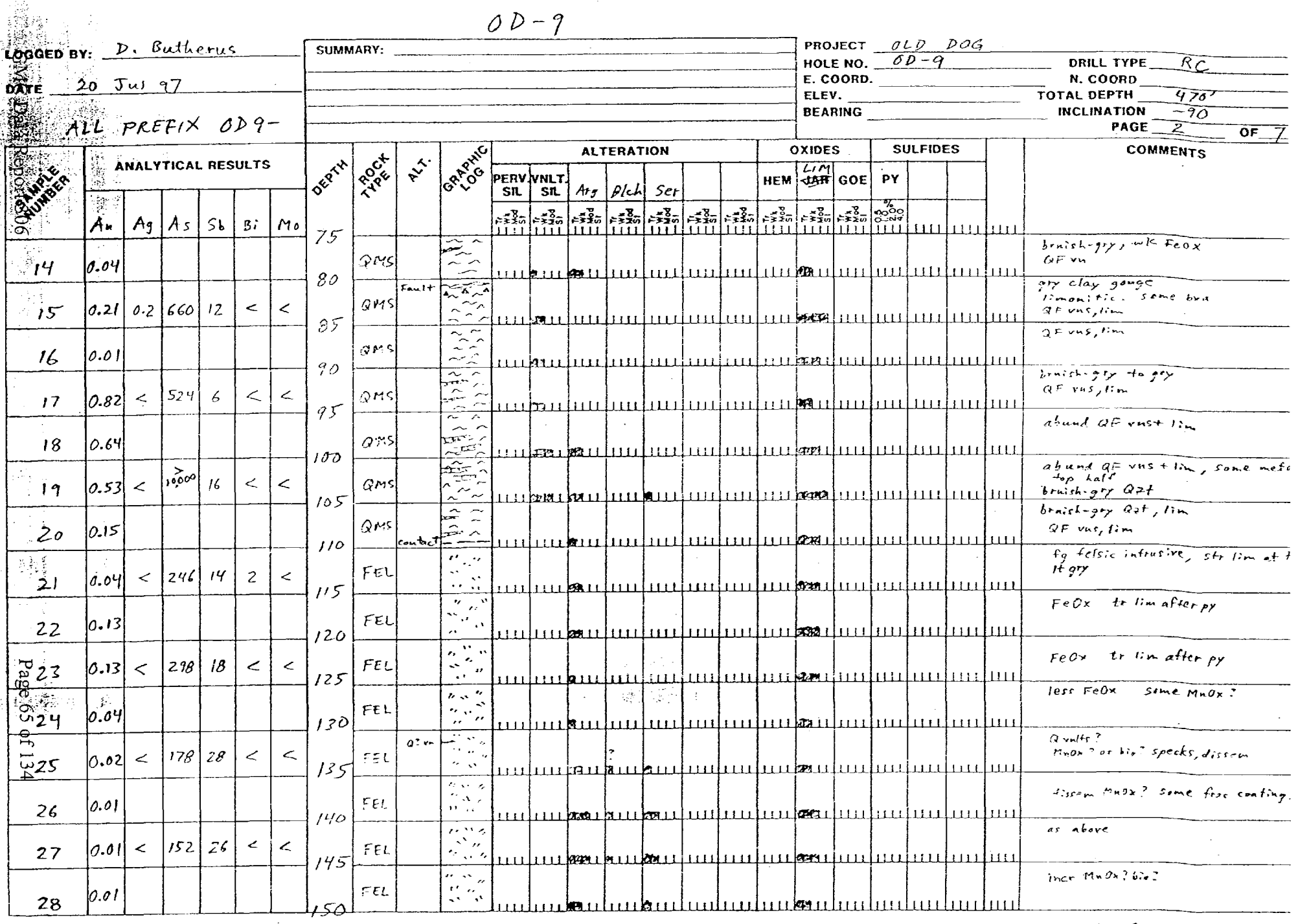




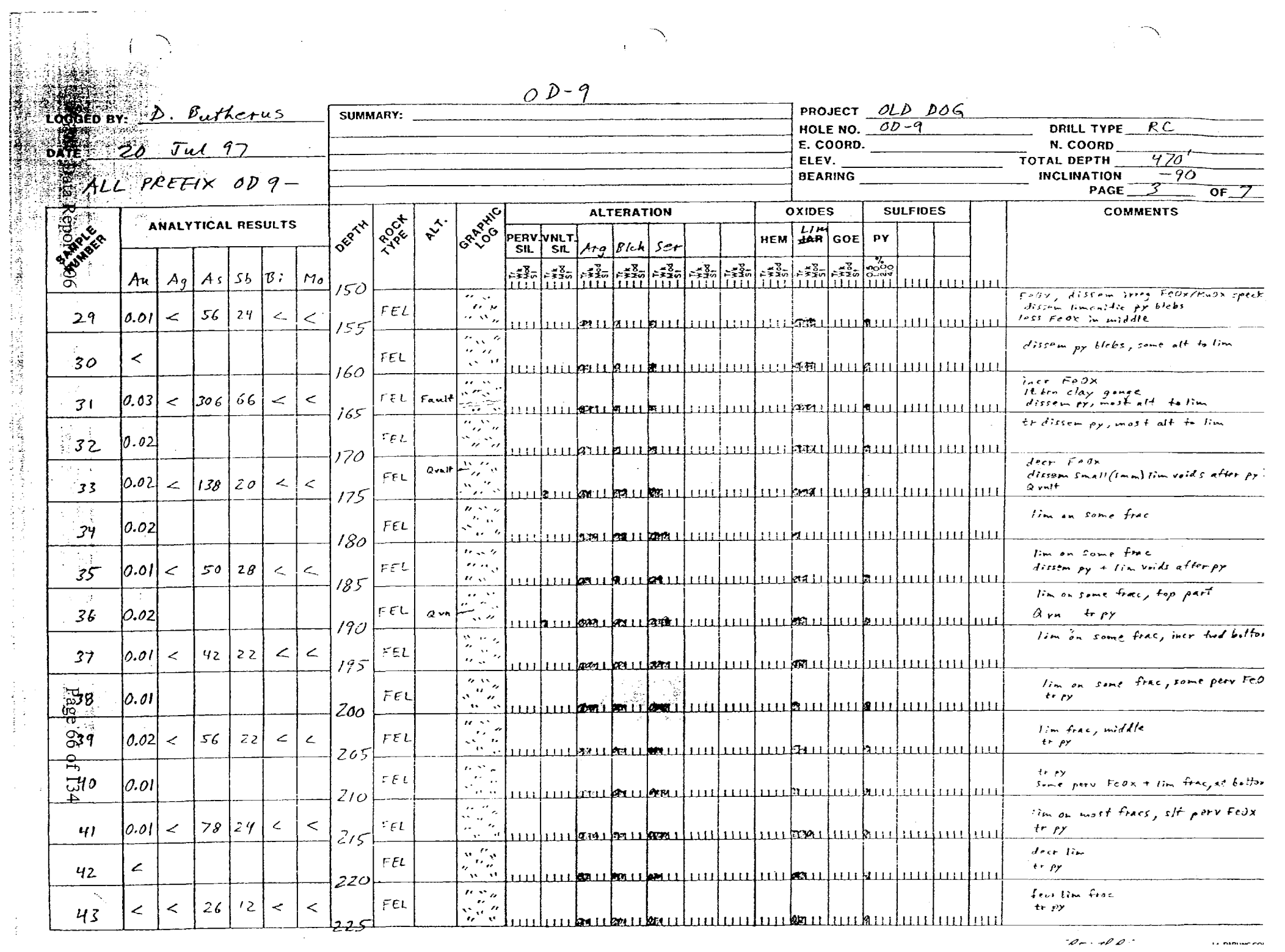




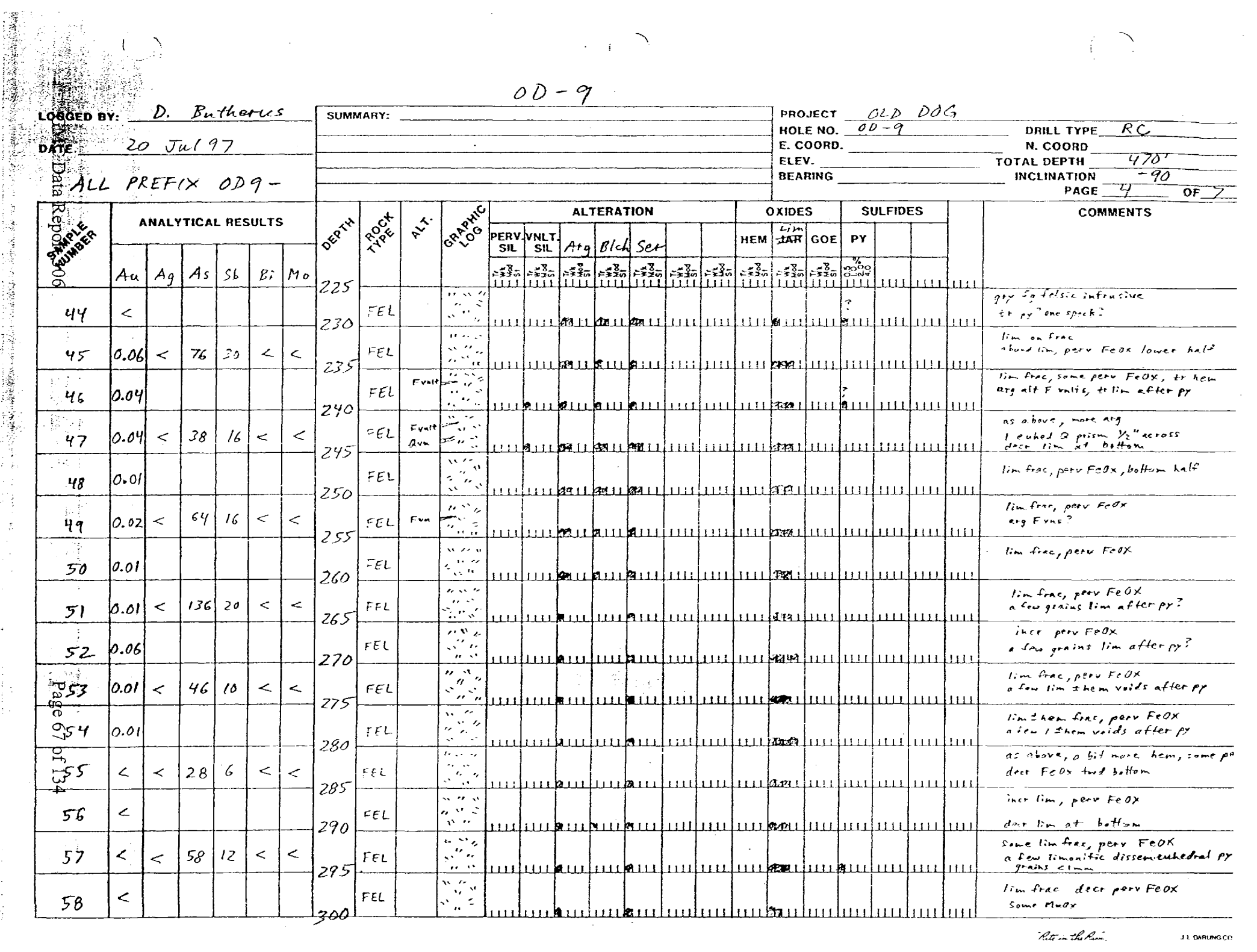




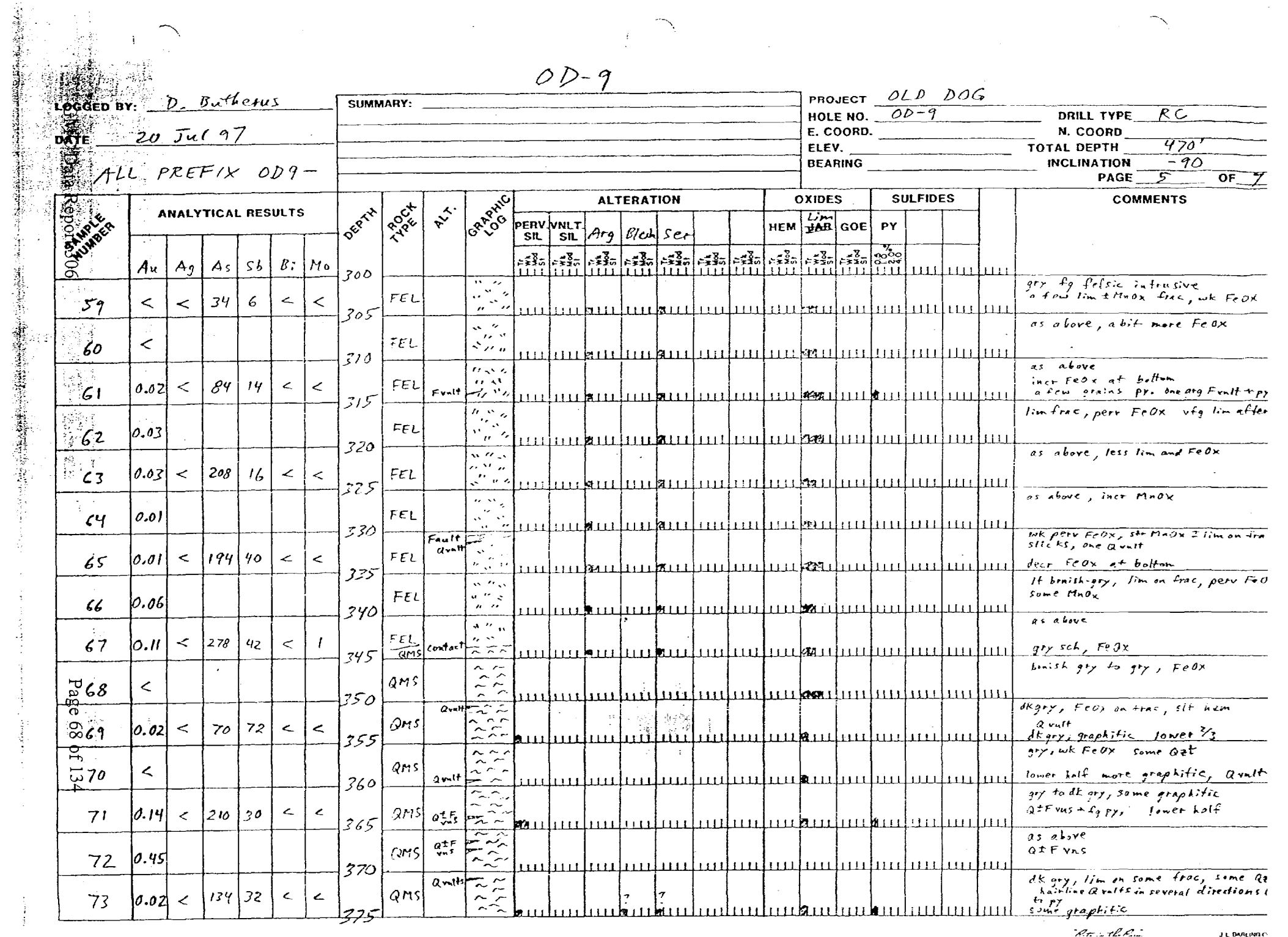




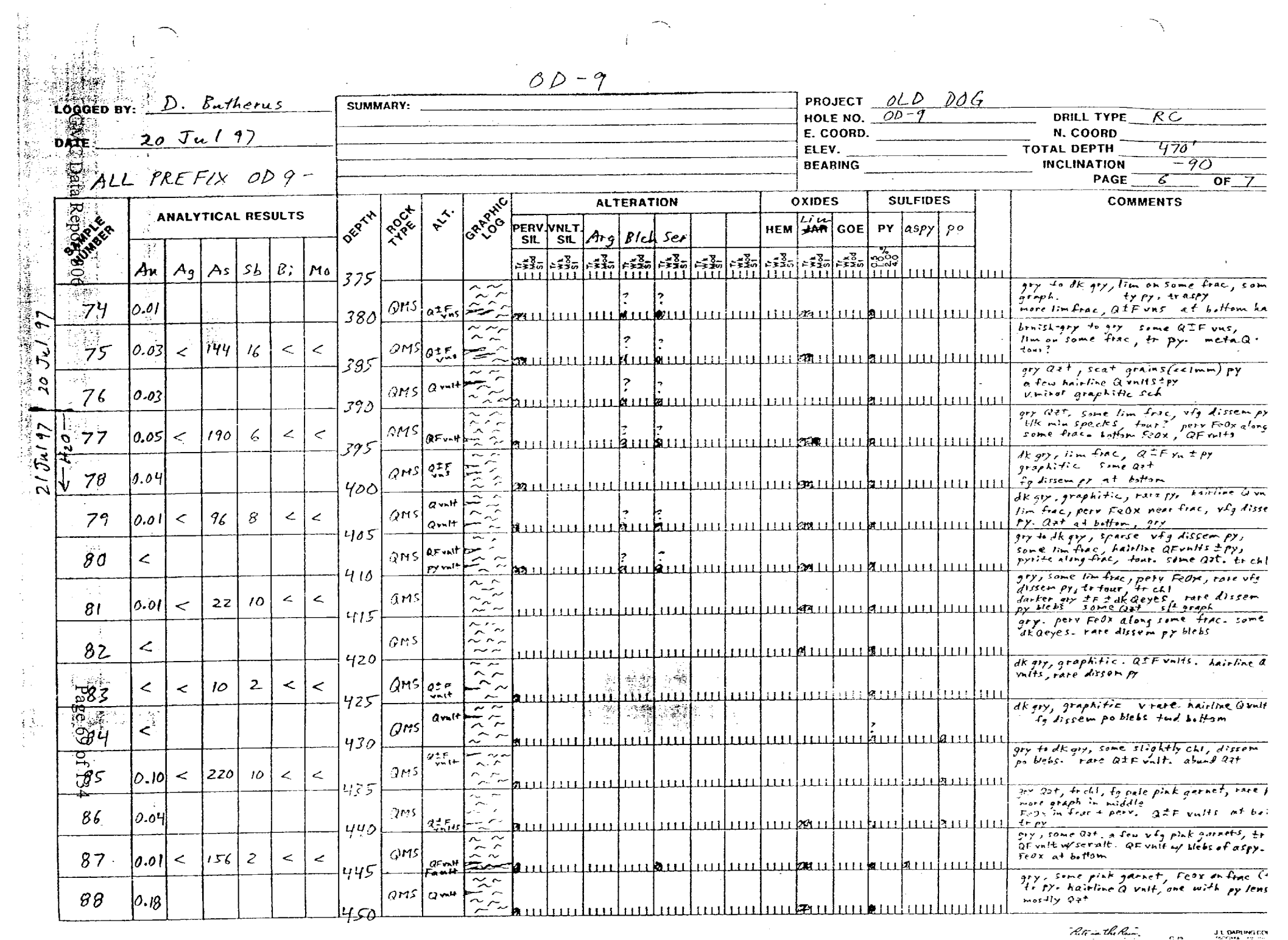




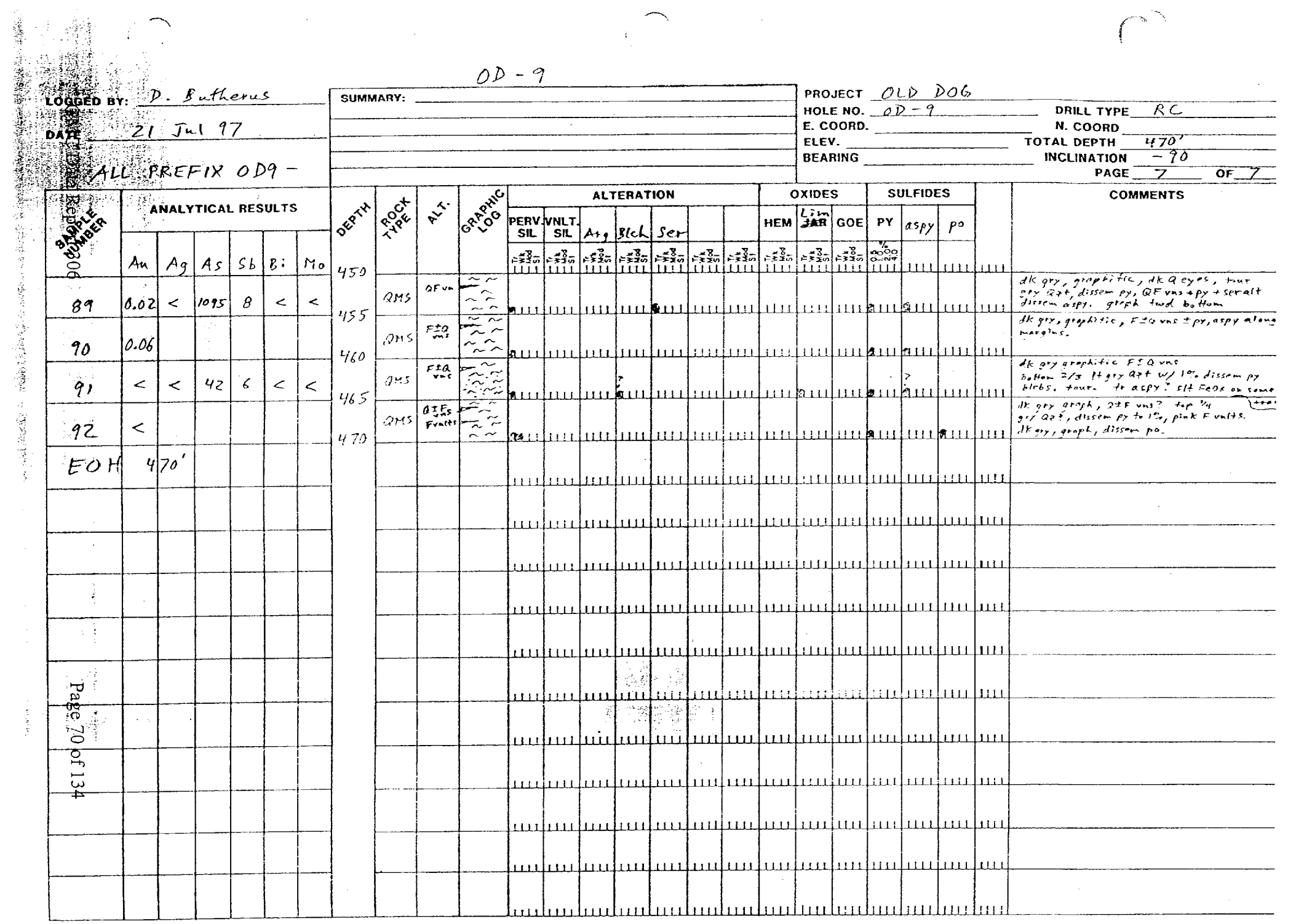

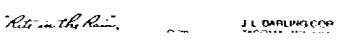




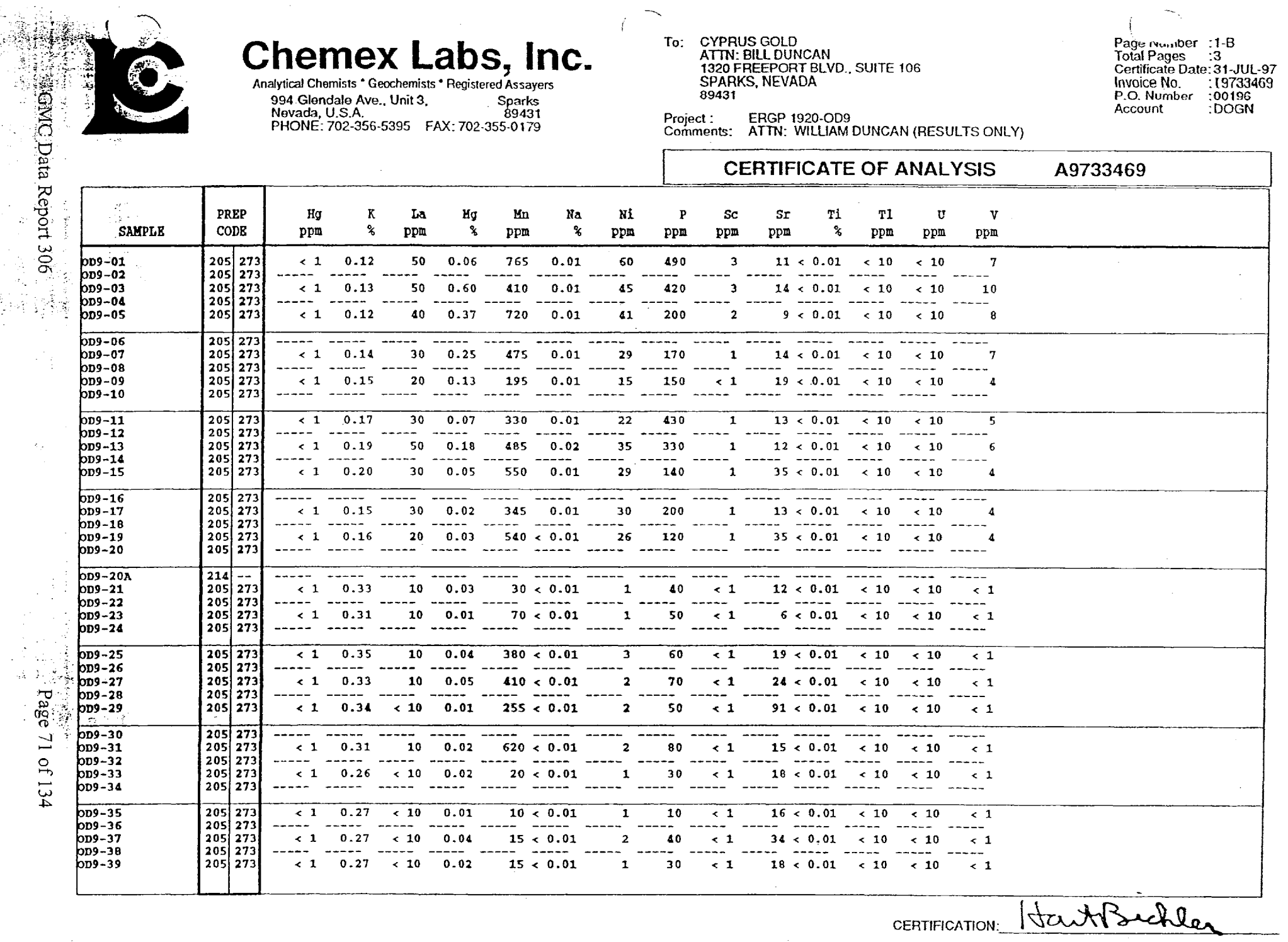




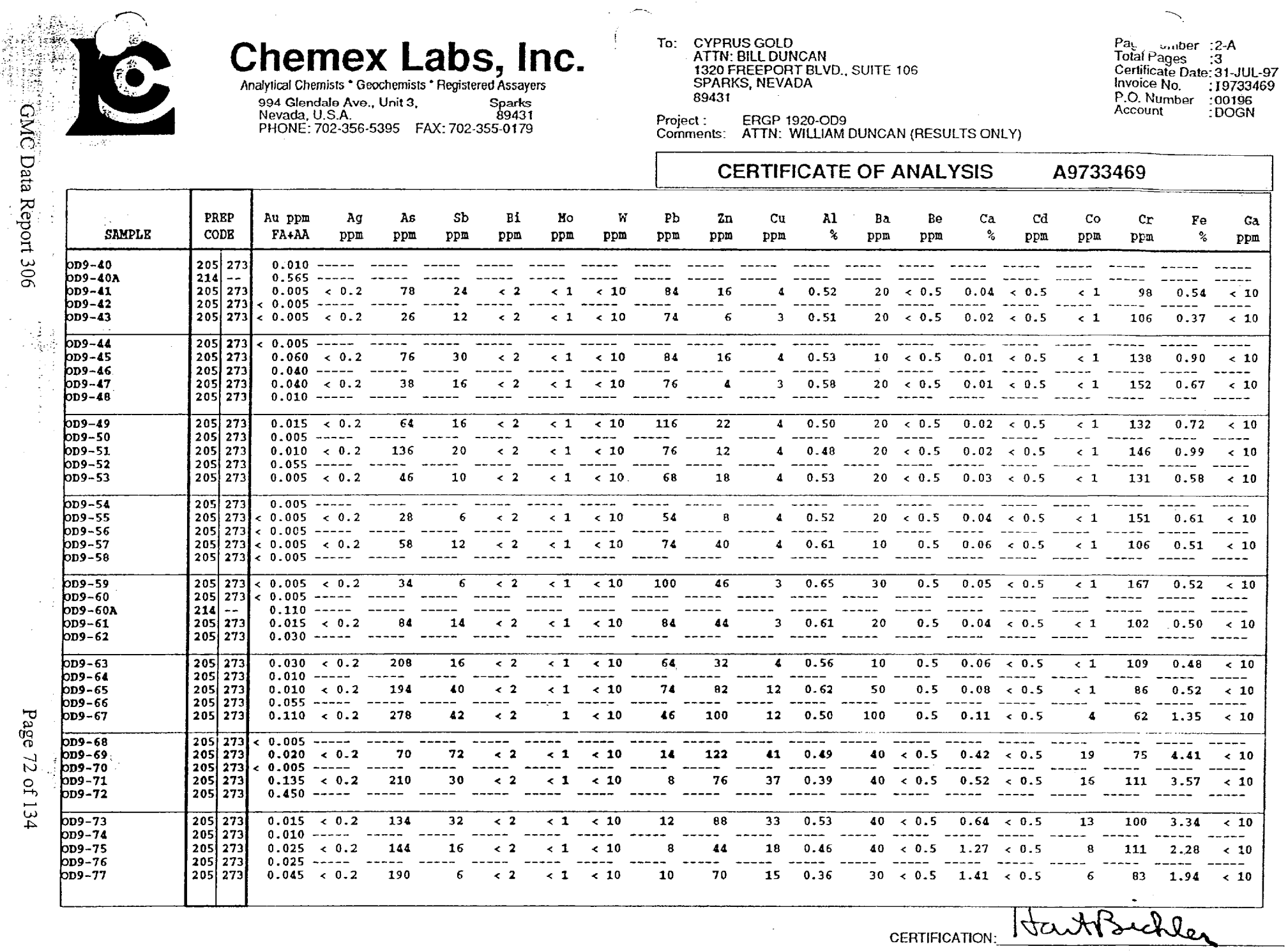




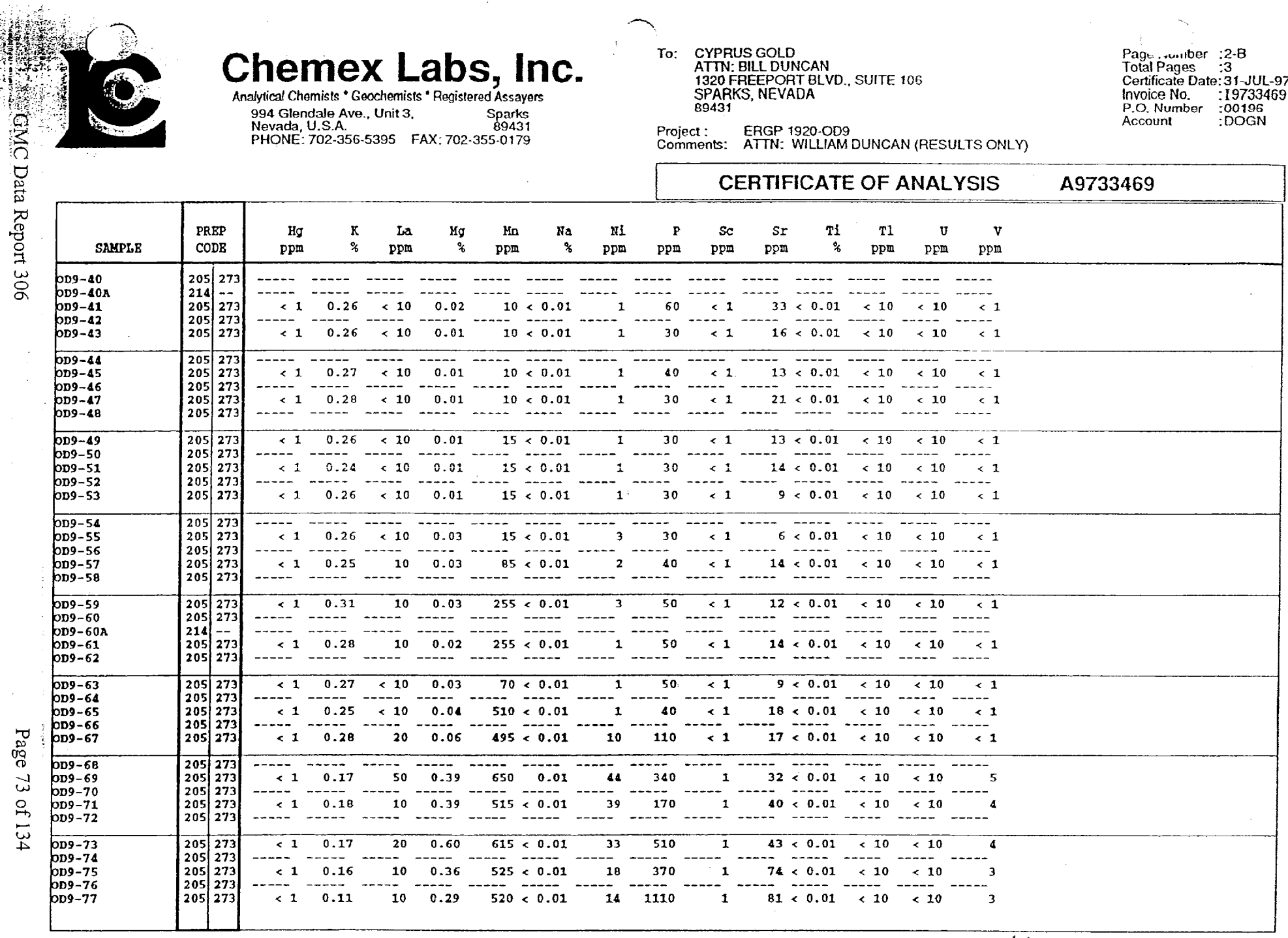




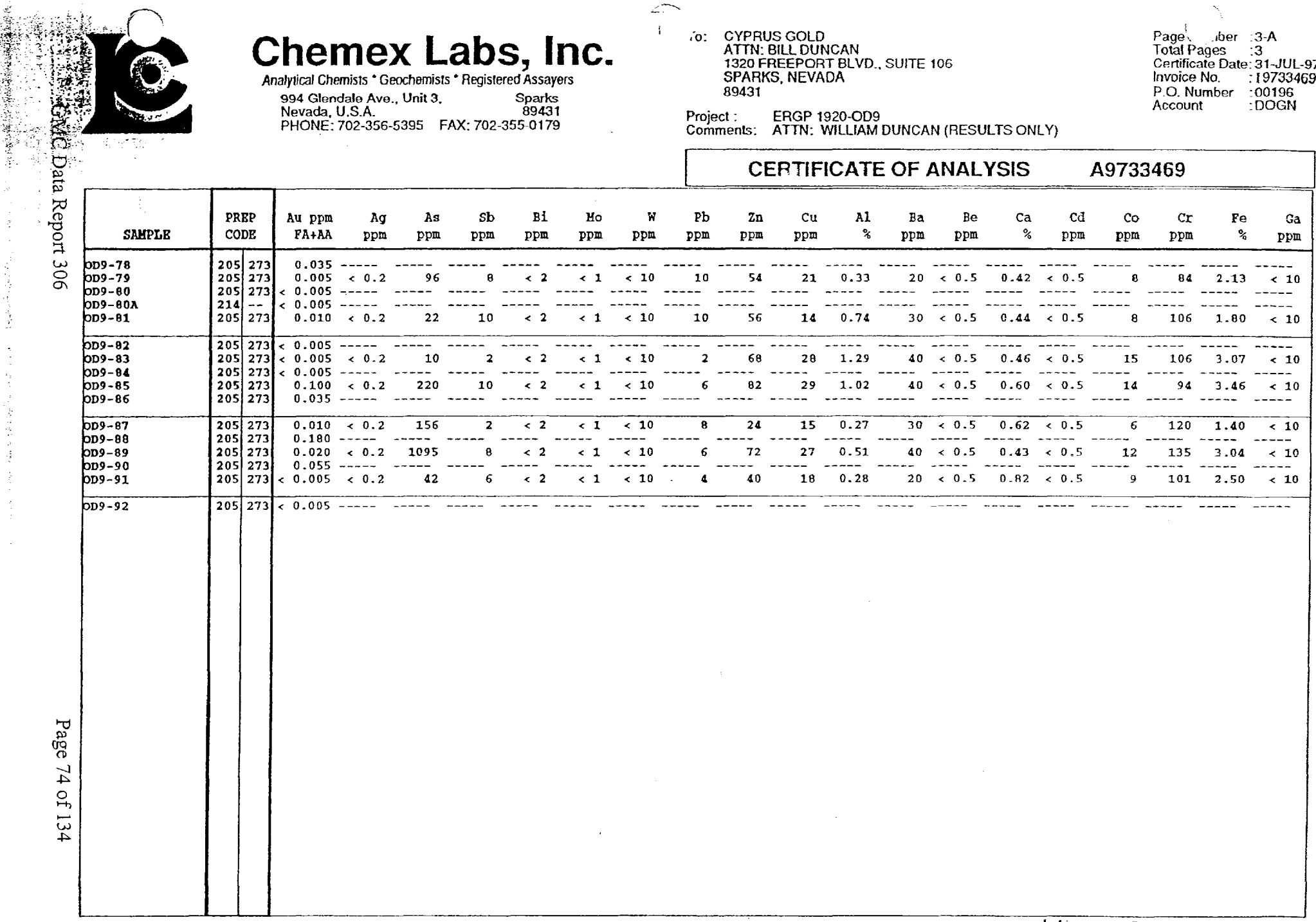

cétFFCATION: ItoutBrchlen 


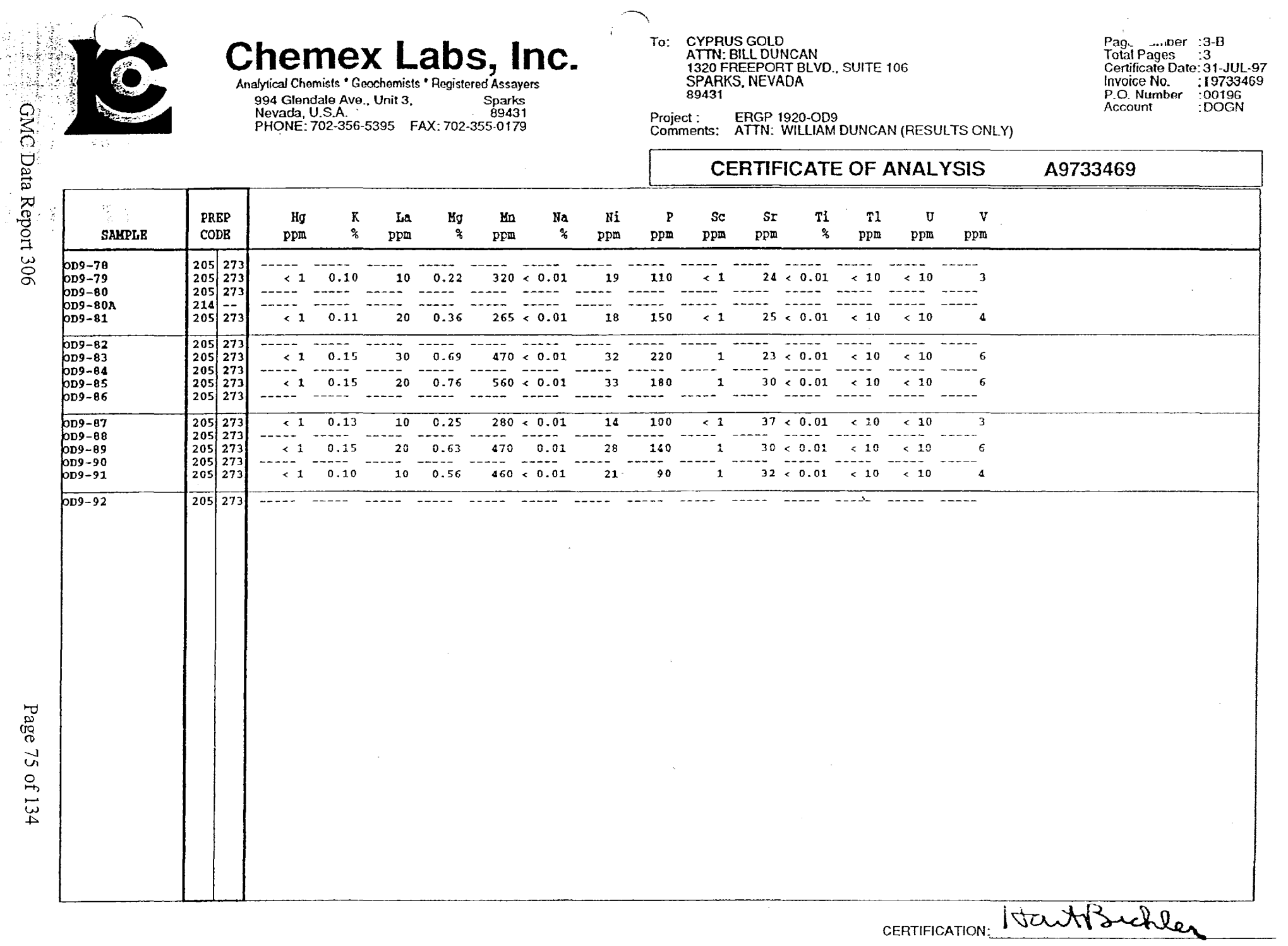




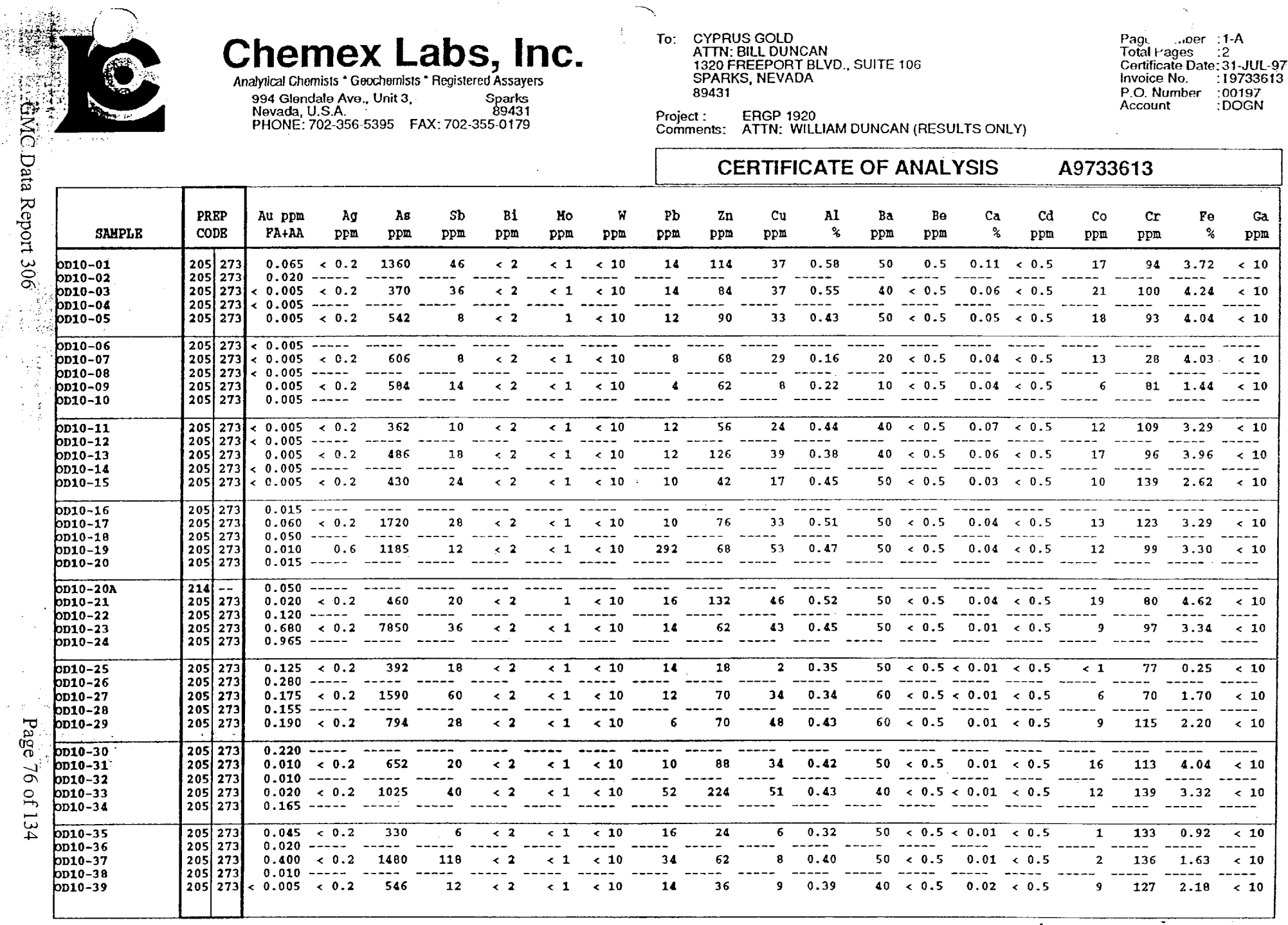




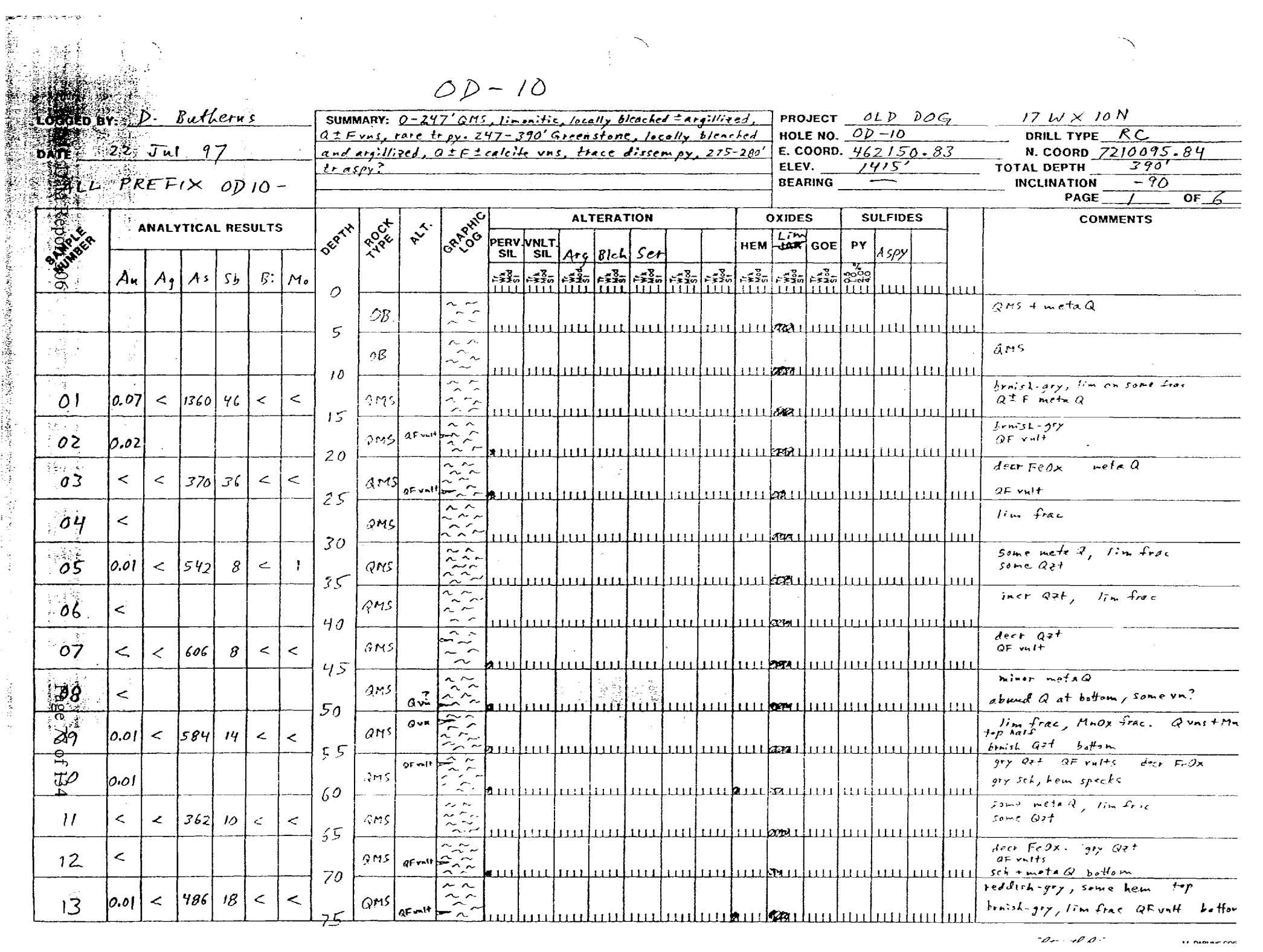




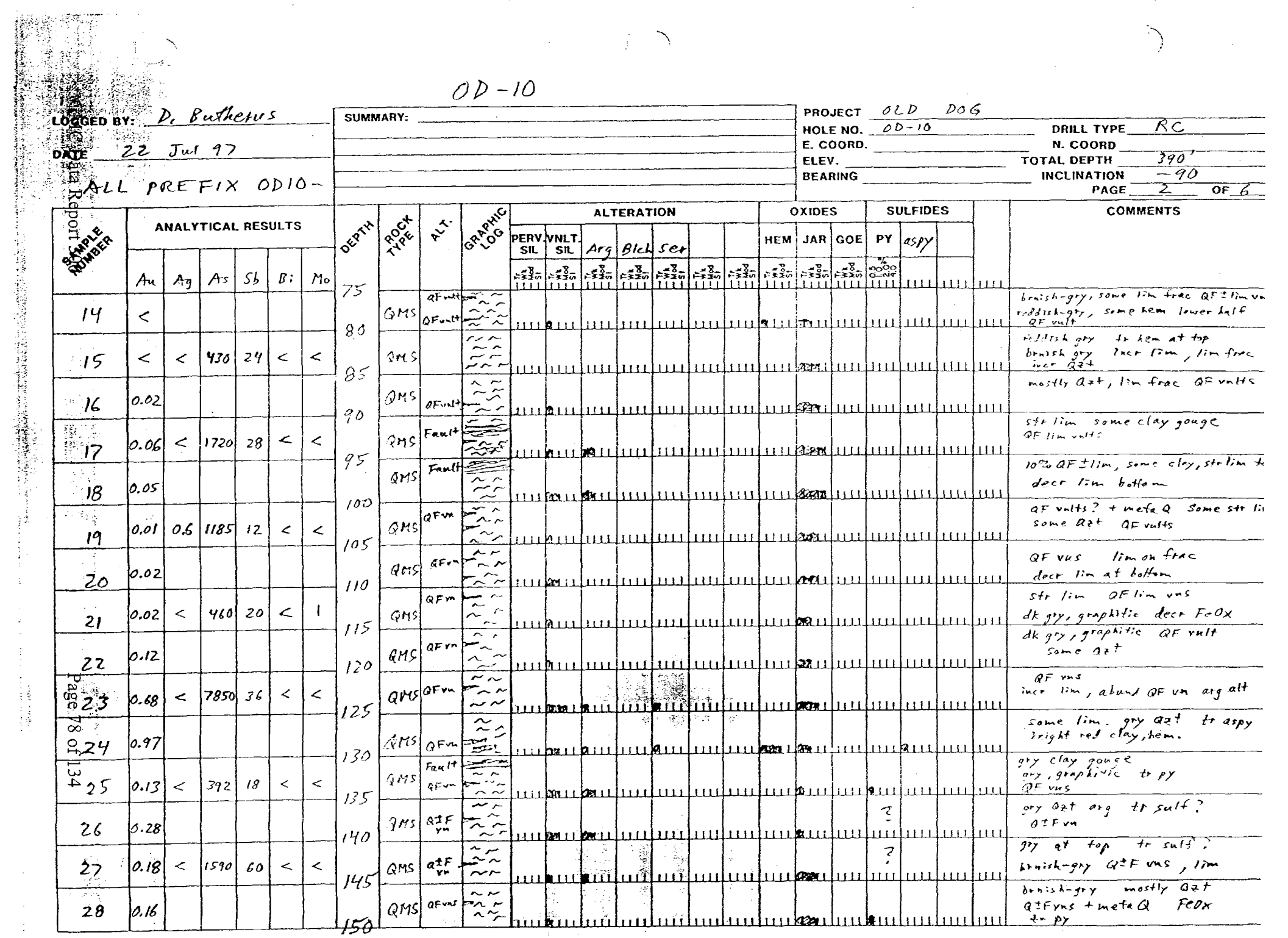




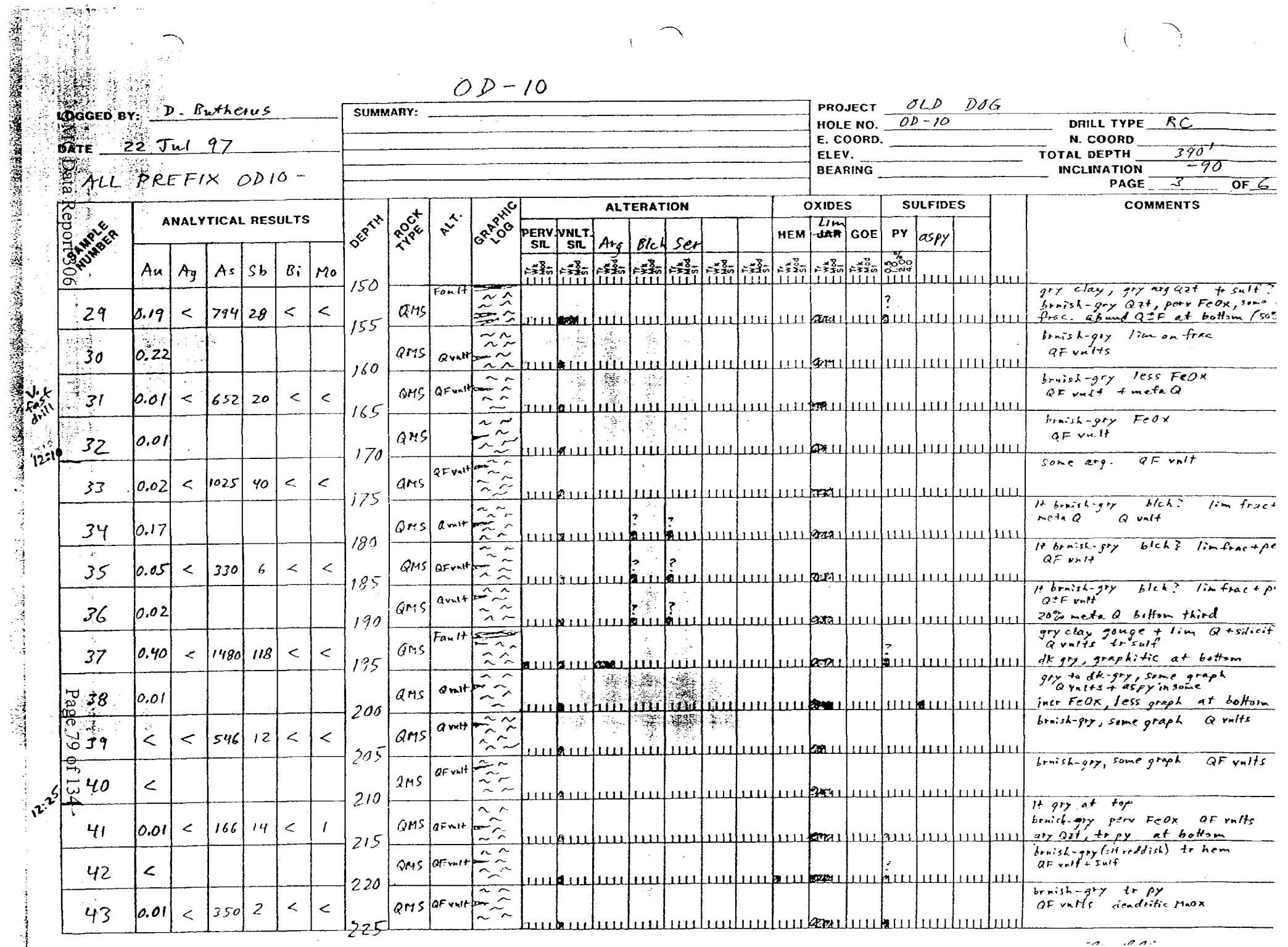




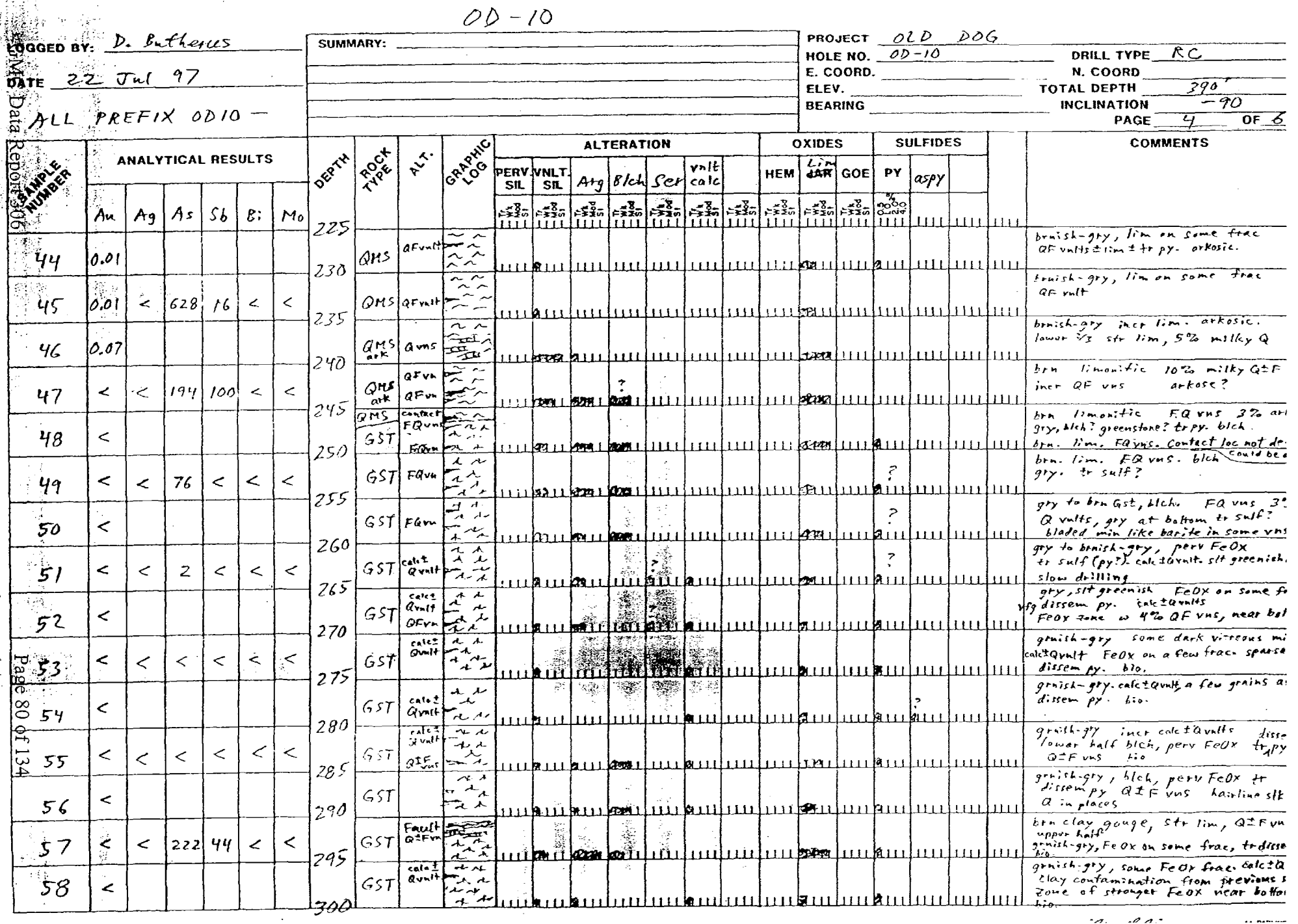




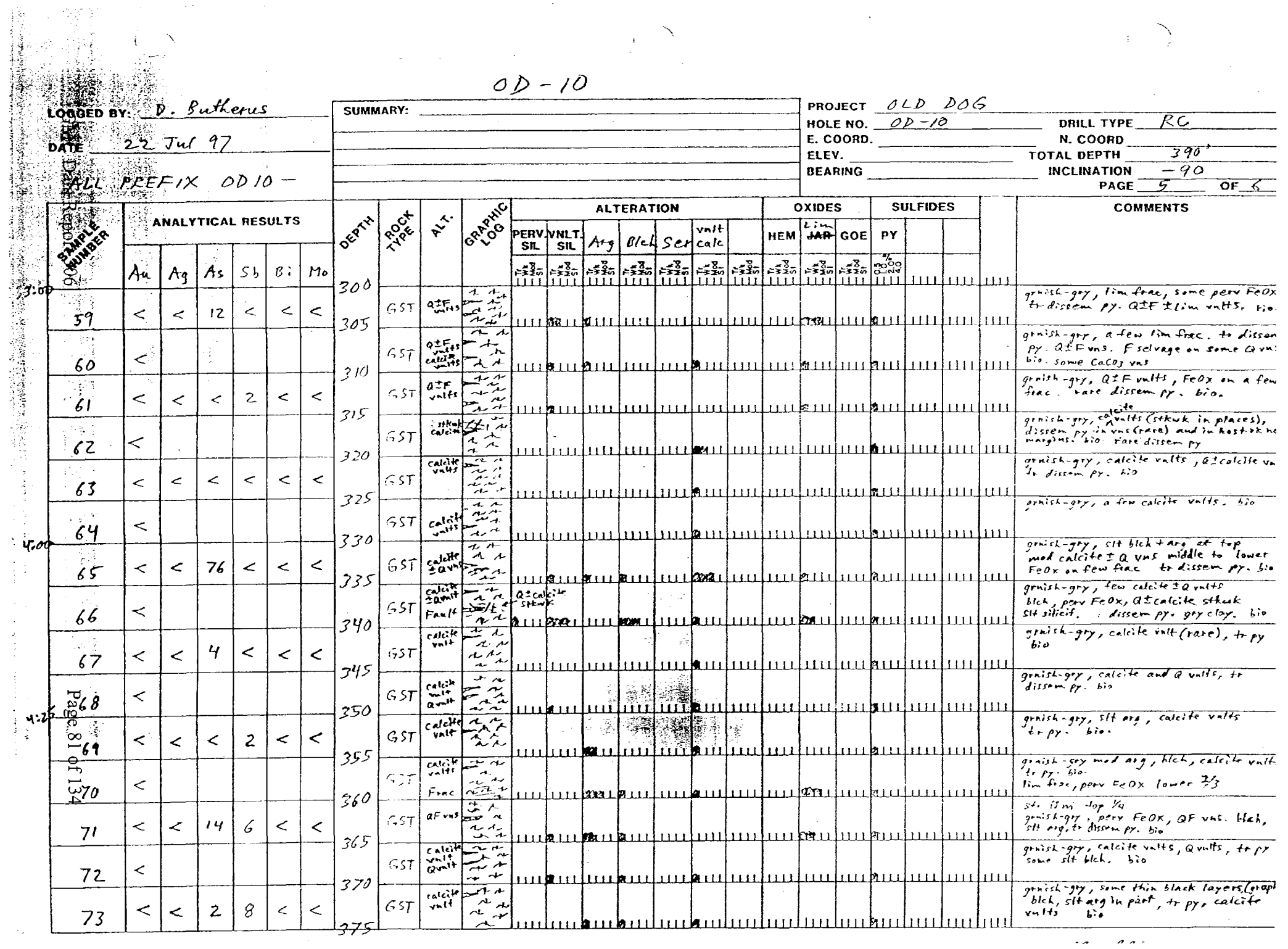


$O D-10$

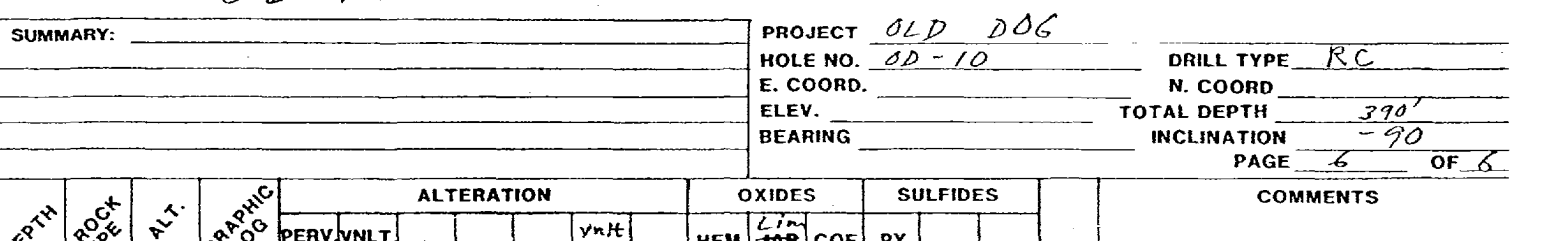

\begin{tabular}{ll|l|l|l|l|l|l|l}
\hline & $A n$ & $A_{g}$ & $A S$ & $S b$ & $B:$ & $M_{0}$ \\
\hline
\end{tabular}

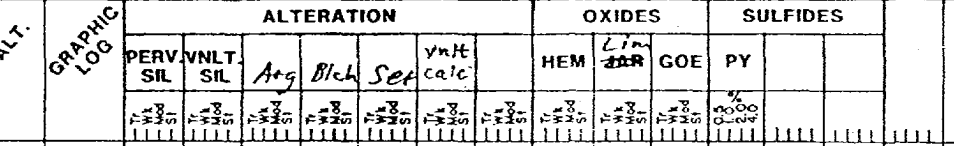

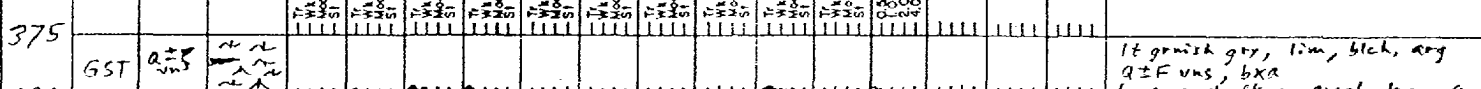

(1t grmixh gry, lim, blch, ang 385

$75 \div<2<<$

$76<$

EOH $390^{\prime}$

$3 ?$

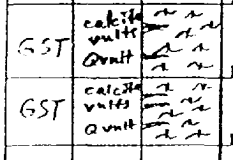

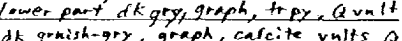

dk qunishary, graph, carcite vults, $Q$

de graish-goy, calcite ralts. Quenlts

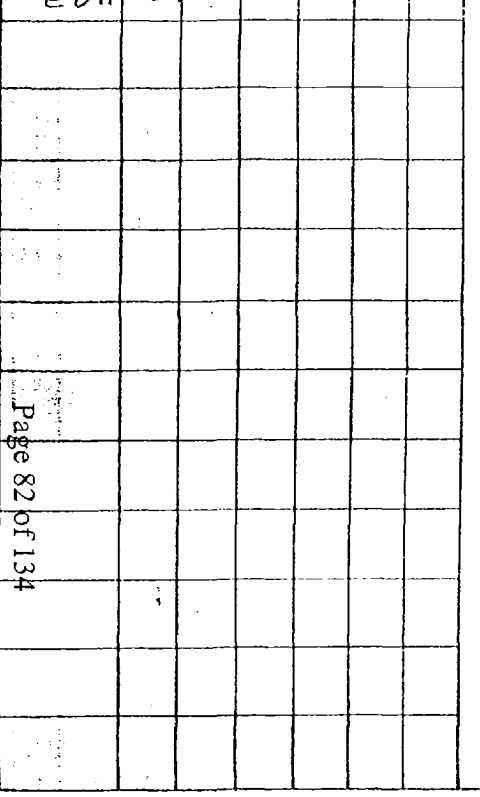

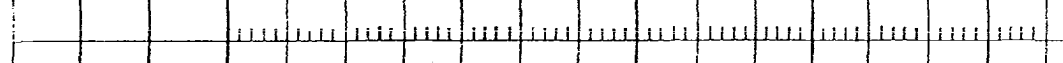

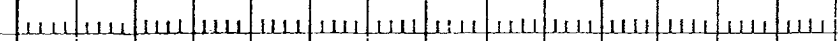

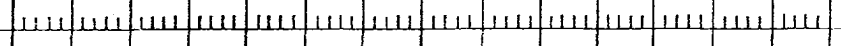

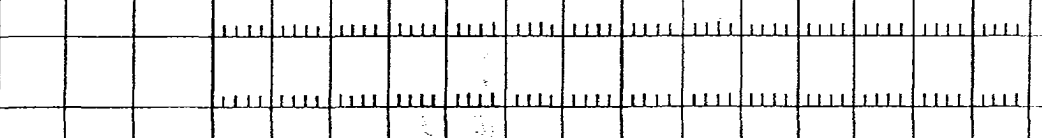

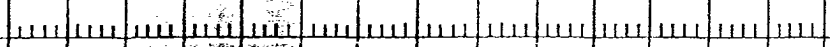

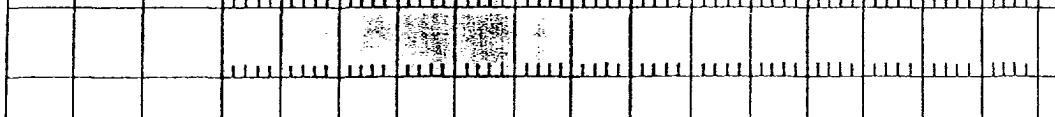

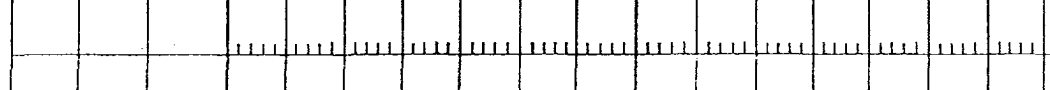

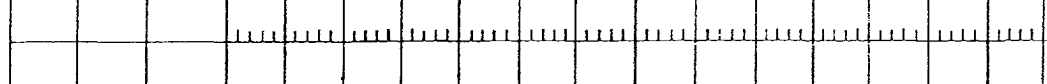

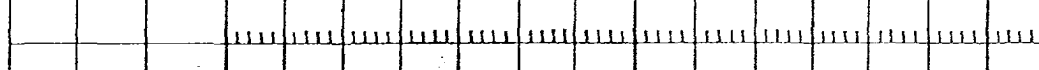

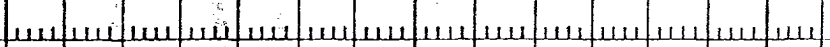

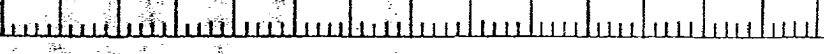




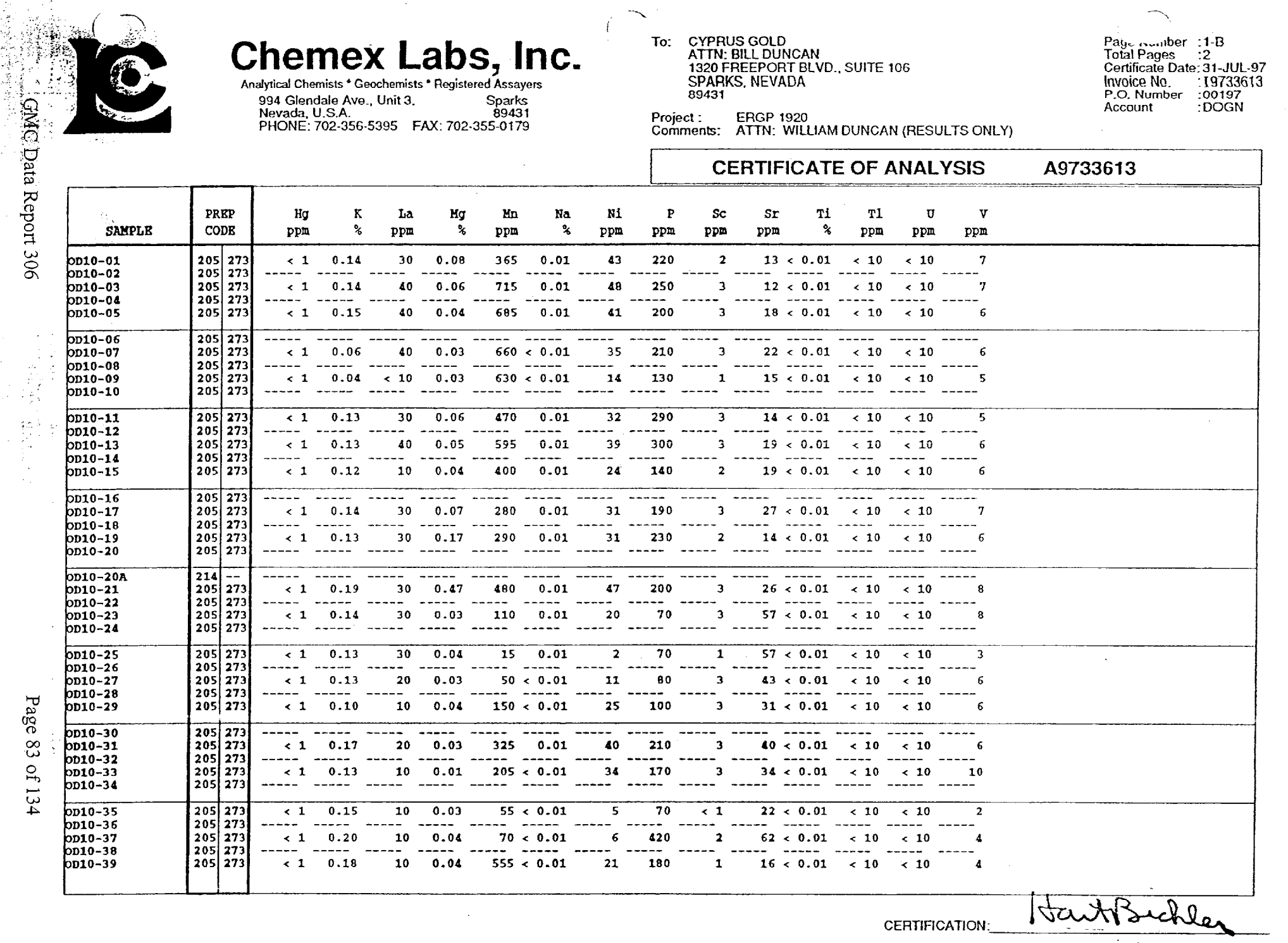




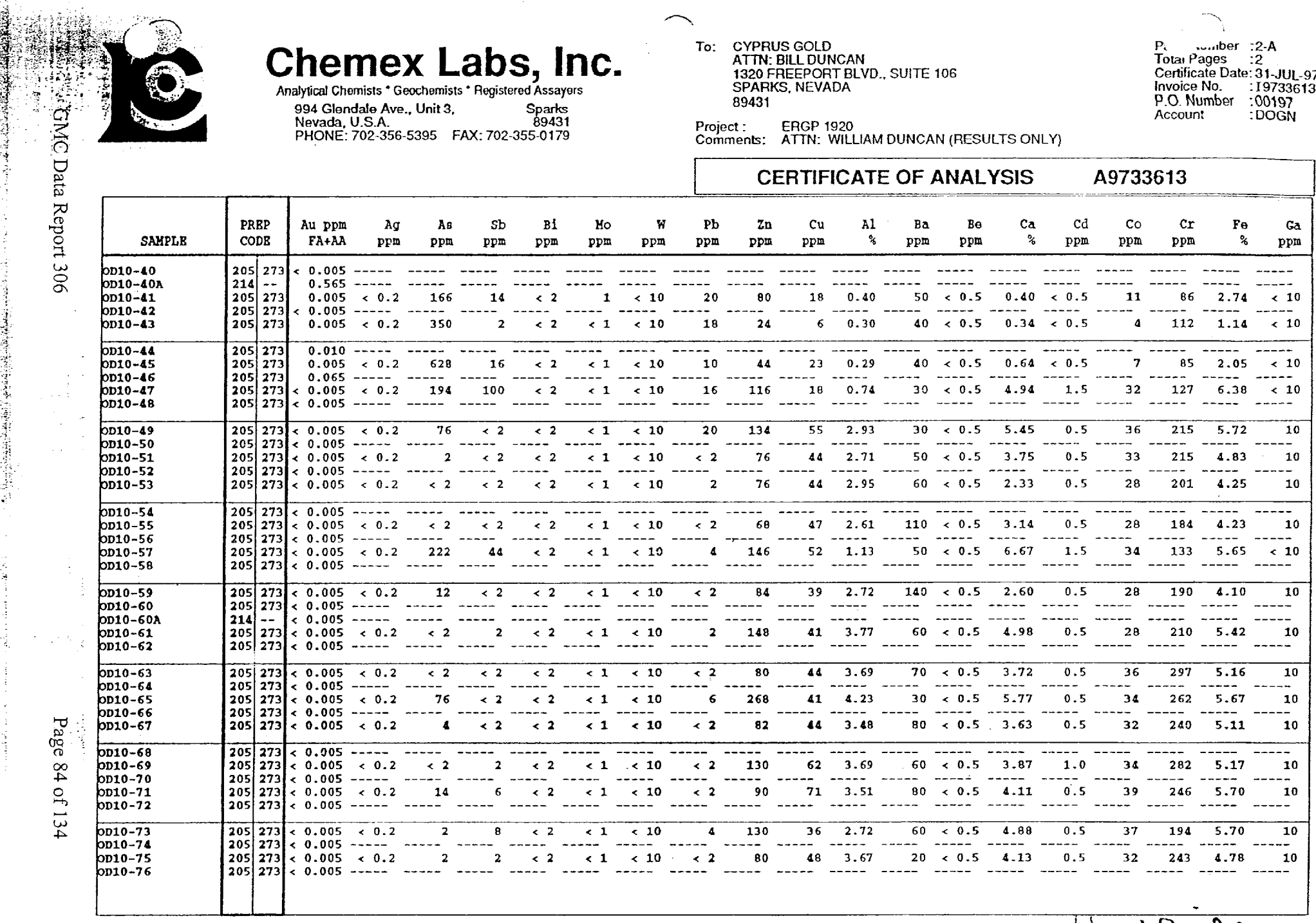




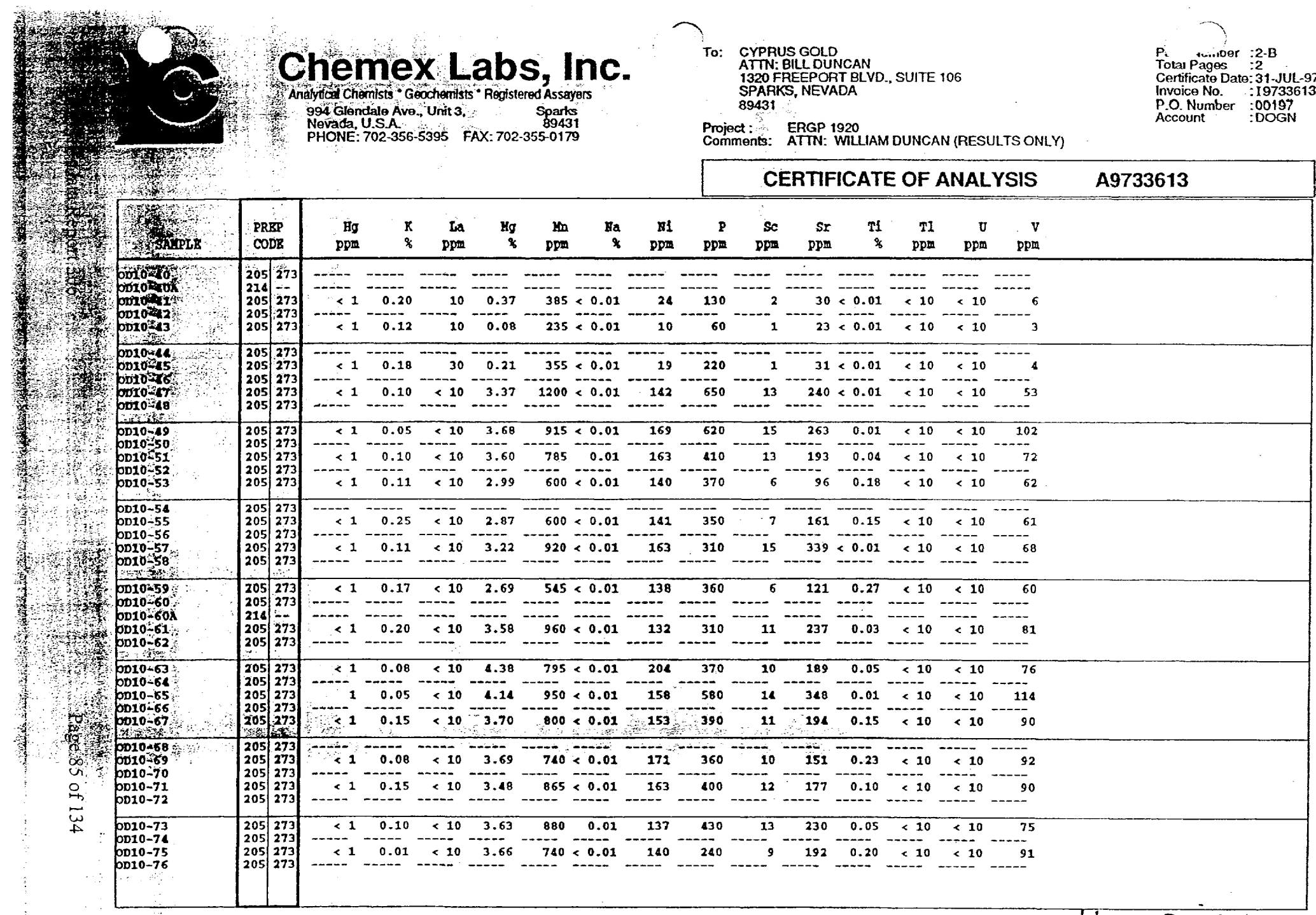


Chemex Labs, Inc. Analytical Chemlsts " Geochemists " Registered Assayers 994 Glendale Ave., Unit 3 . Sparks
89431 PHONE: 702-356-5395 FAX:702-355-0179
To: CYPRUS GOLD

ATTN: BILL DUNCAN SUITE 106 SPARKS. NEVADA
Patal Pages : : 3 Certificate Date:05-AUG-9 Invoice No. : :19734194 P.O. Number :00198

Project:
Comments:

\section{CERTIFICATE OF ANALYSIS A9734194}

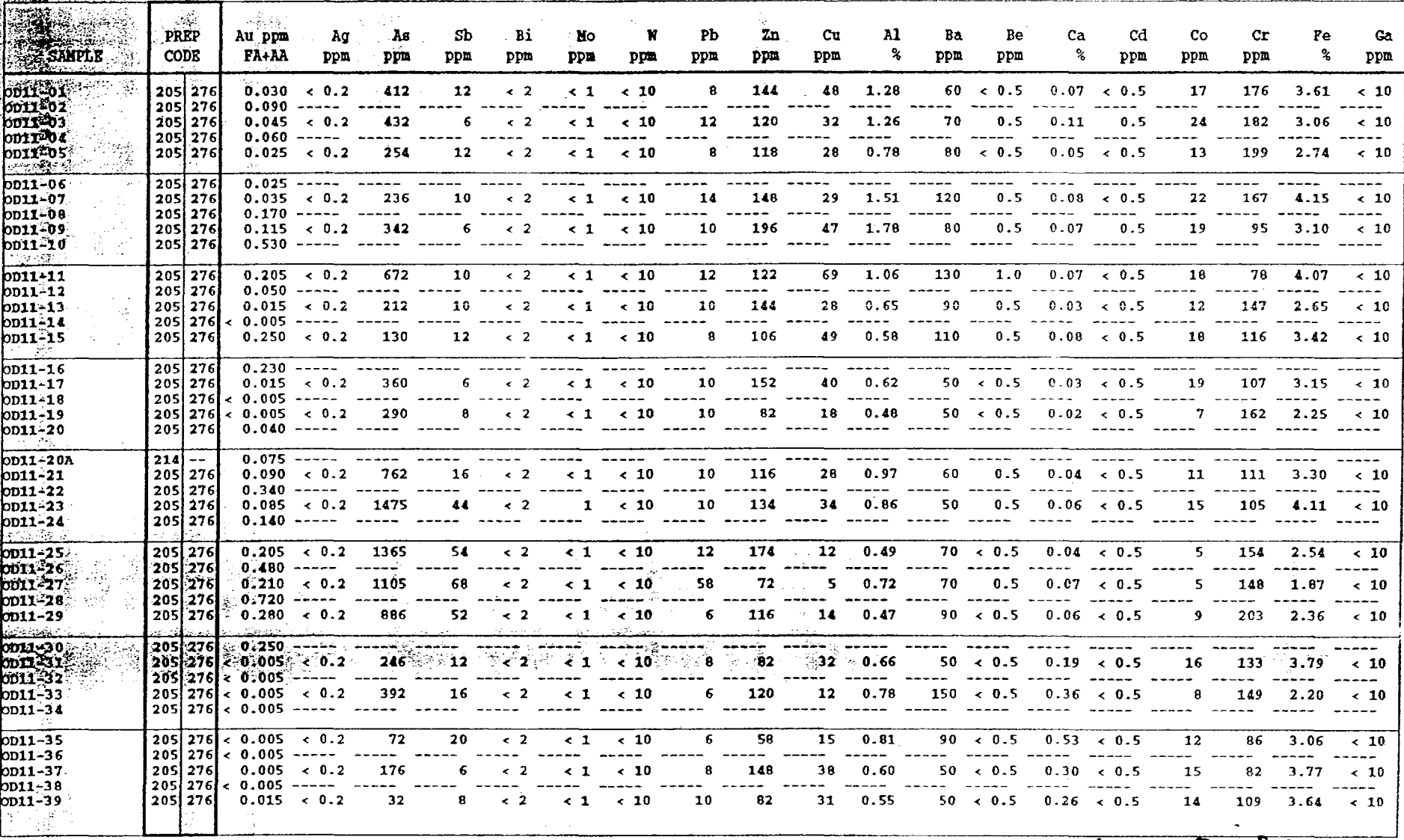




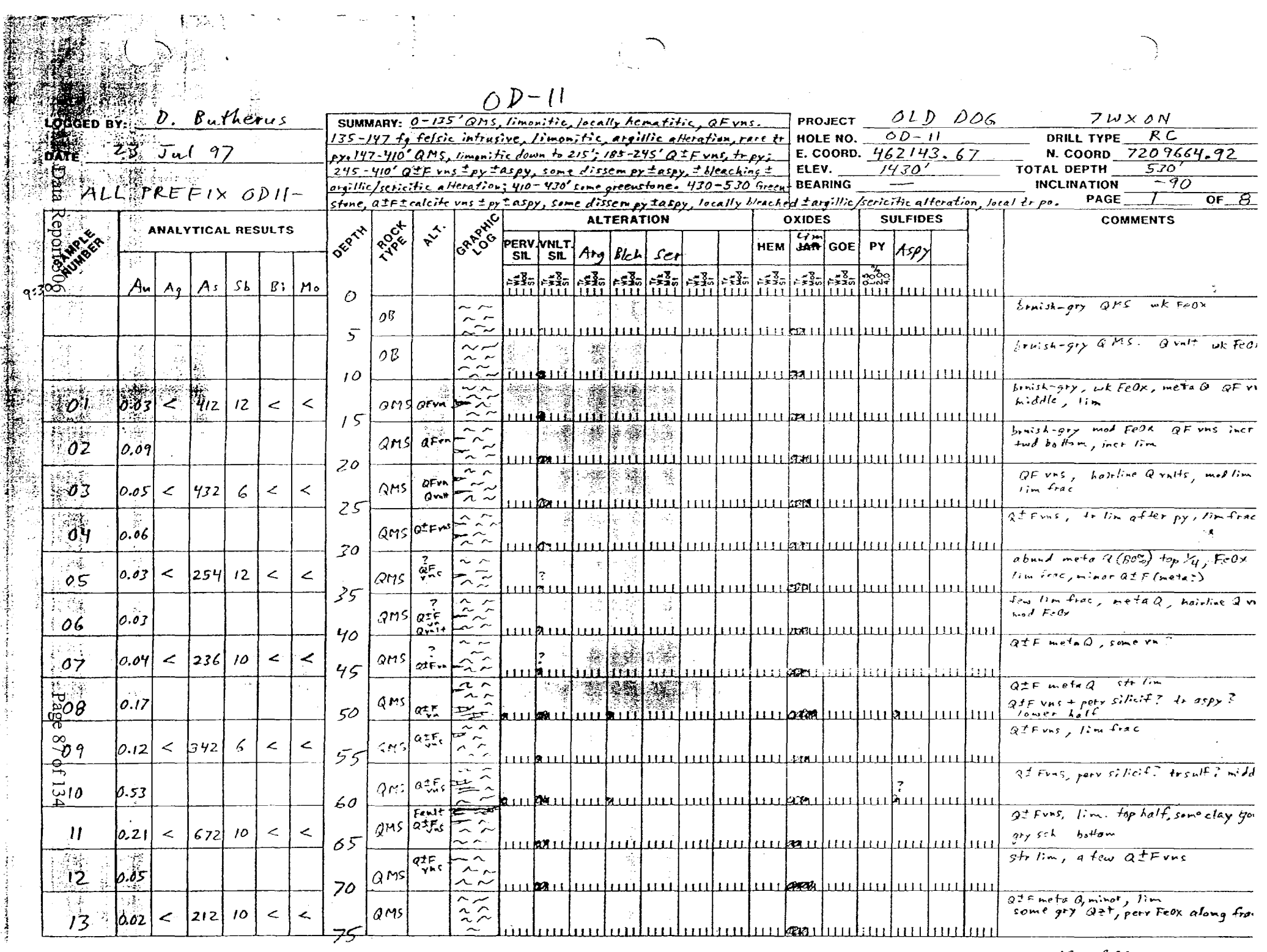




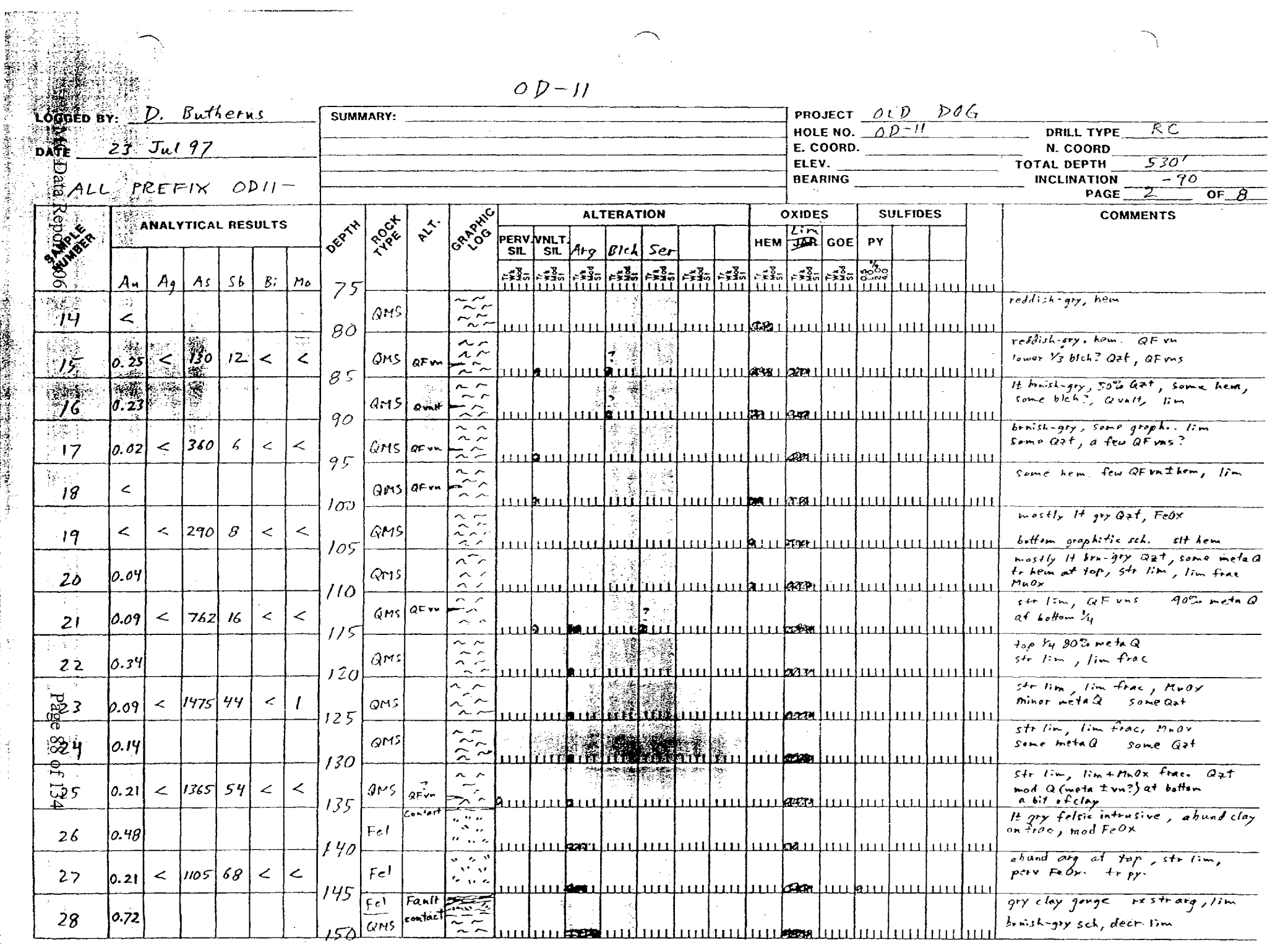

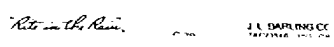




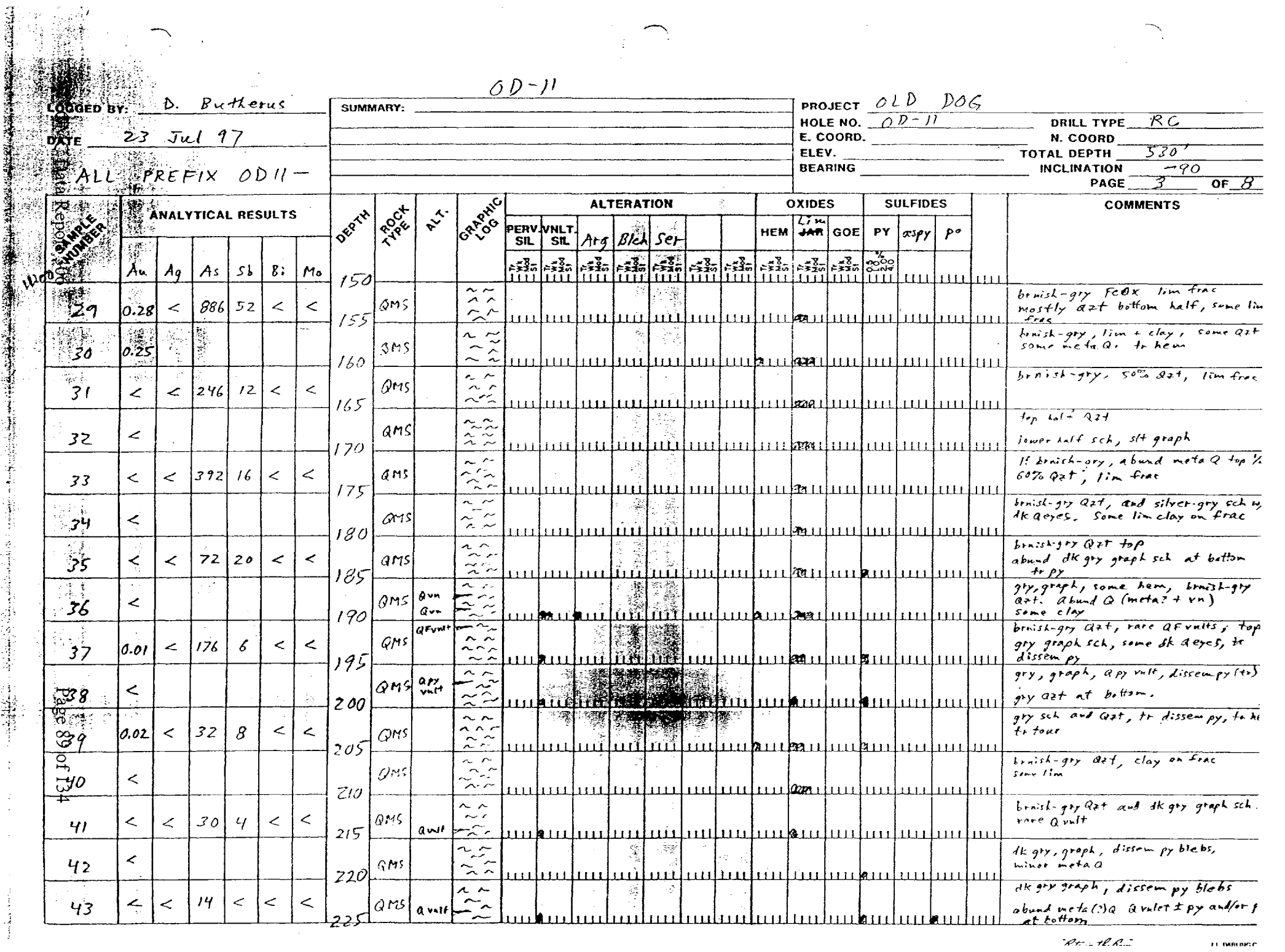



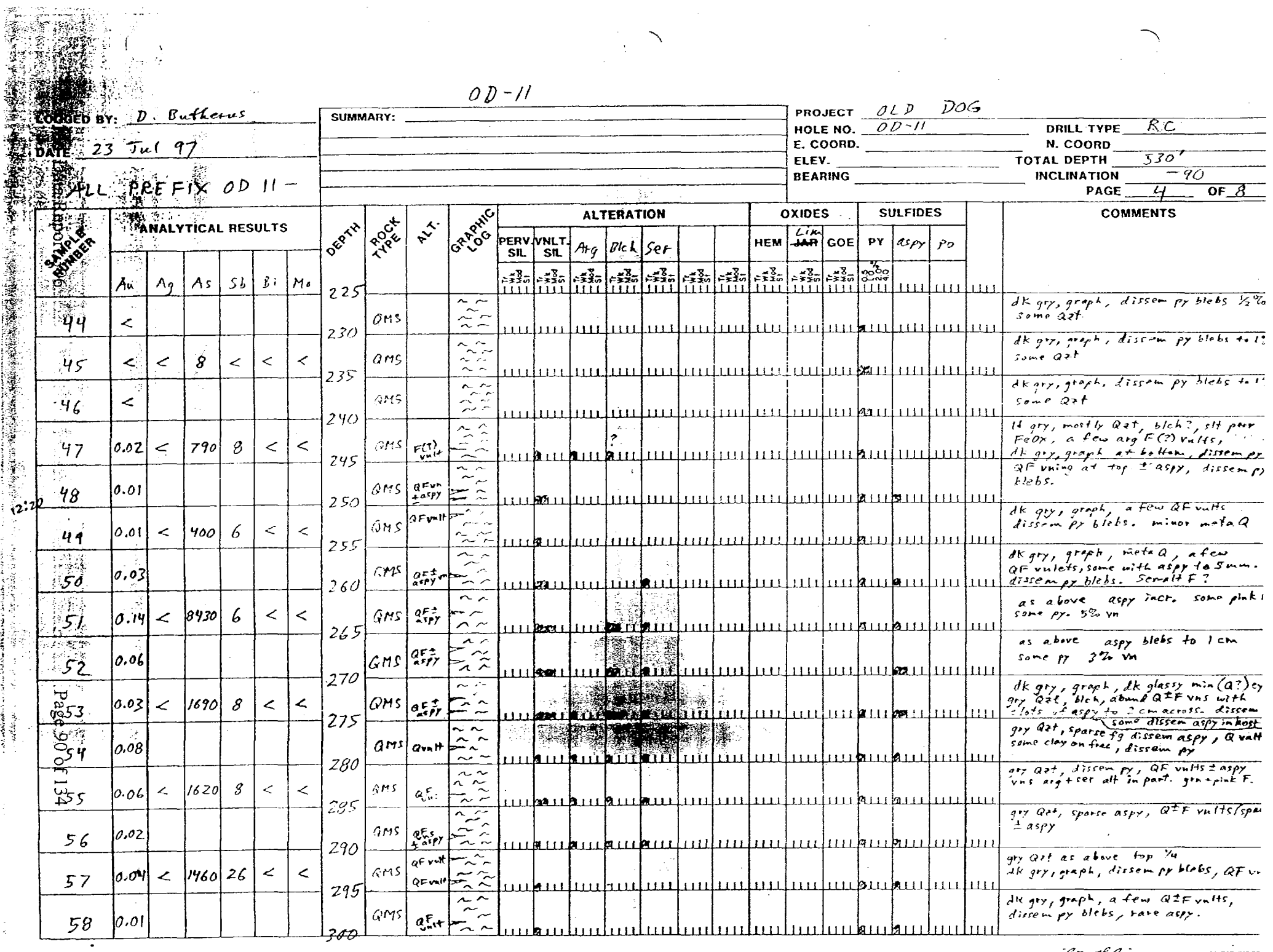


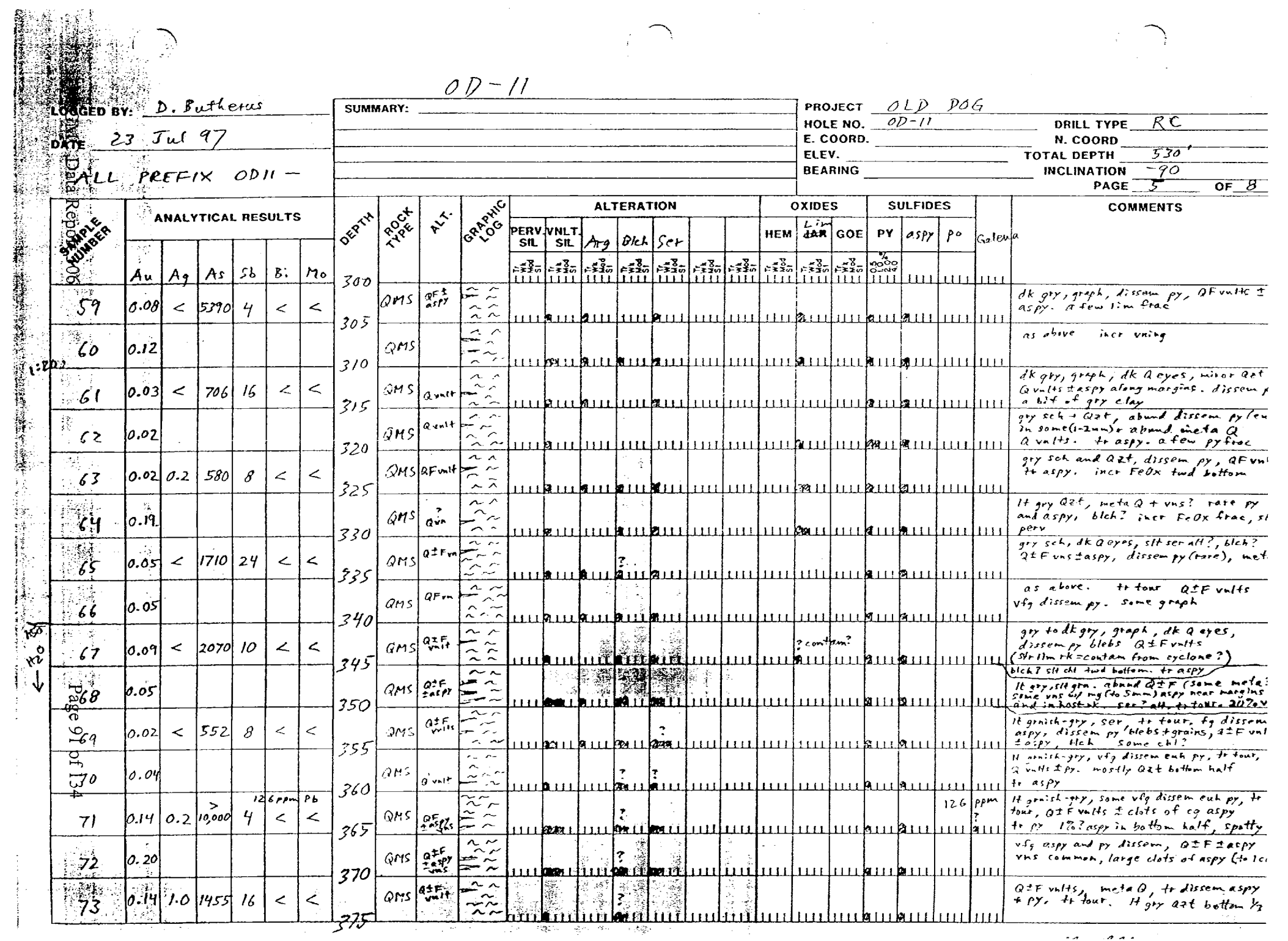




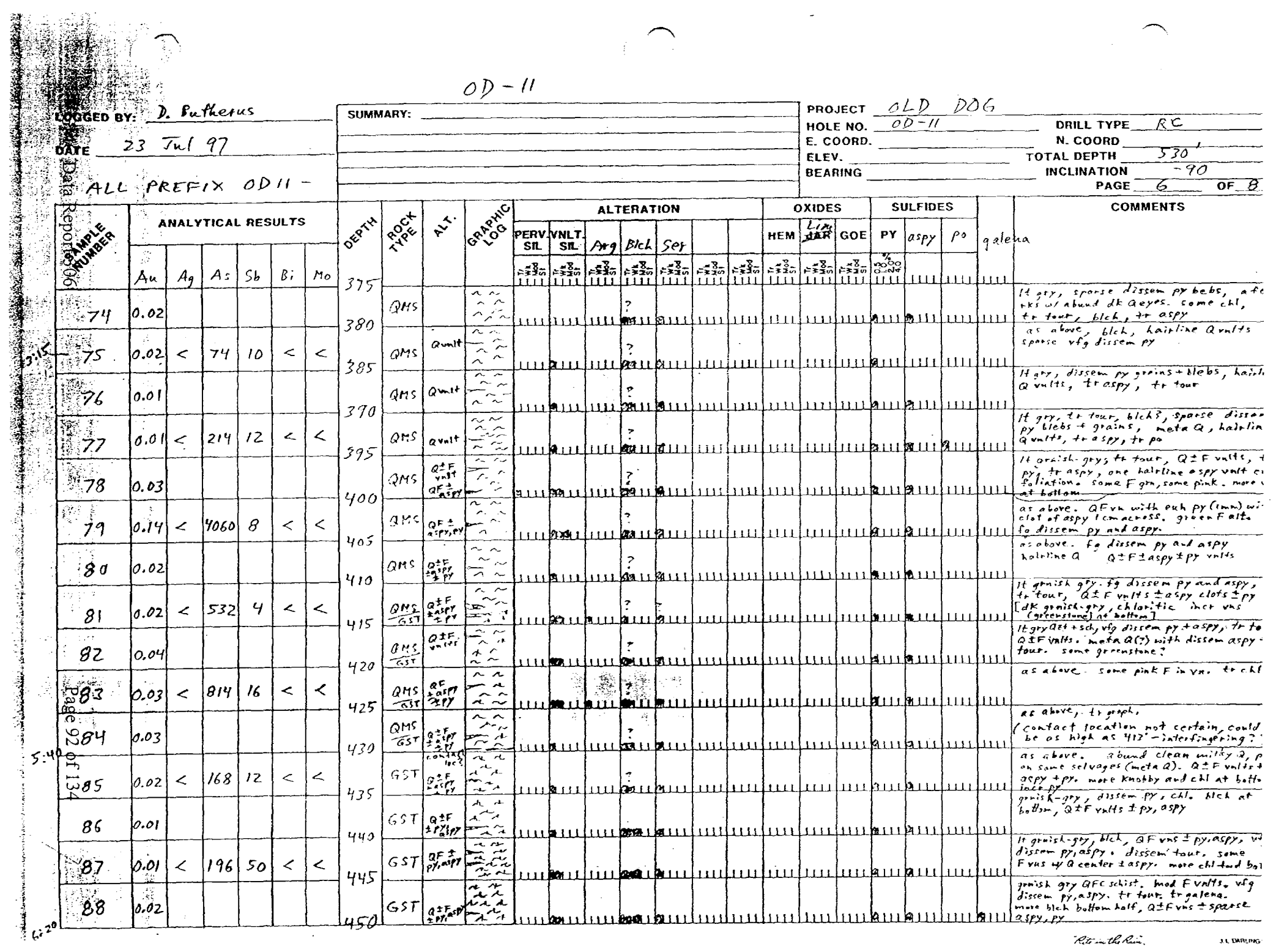




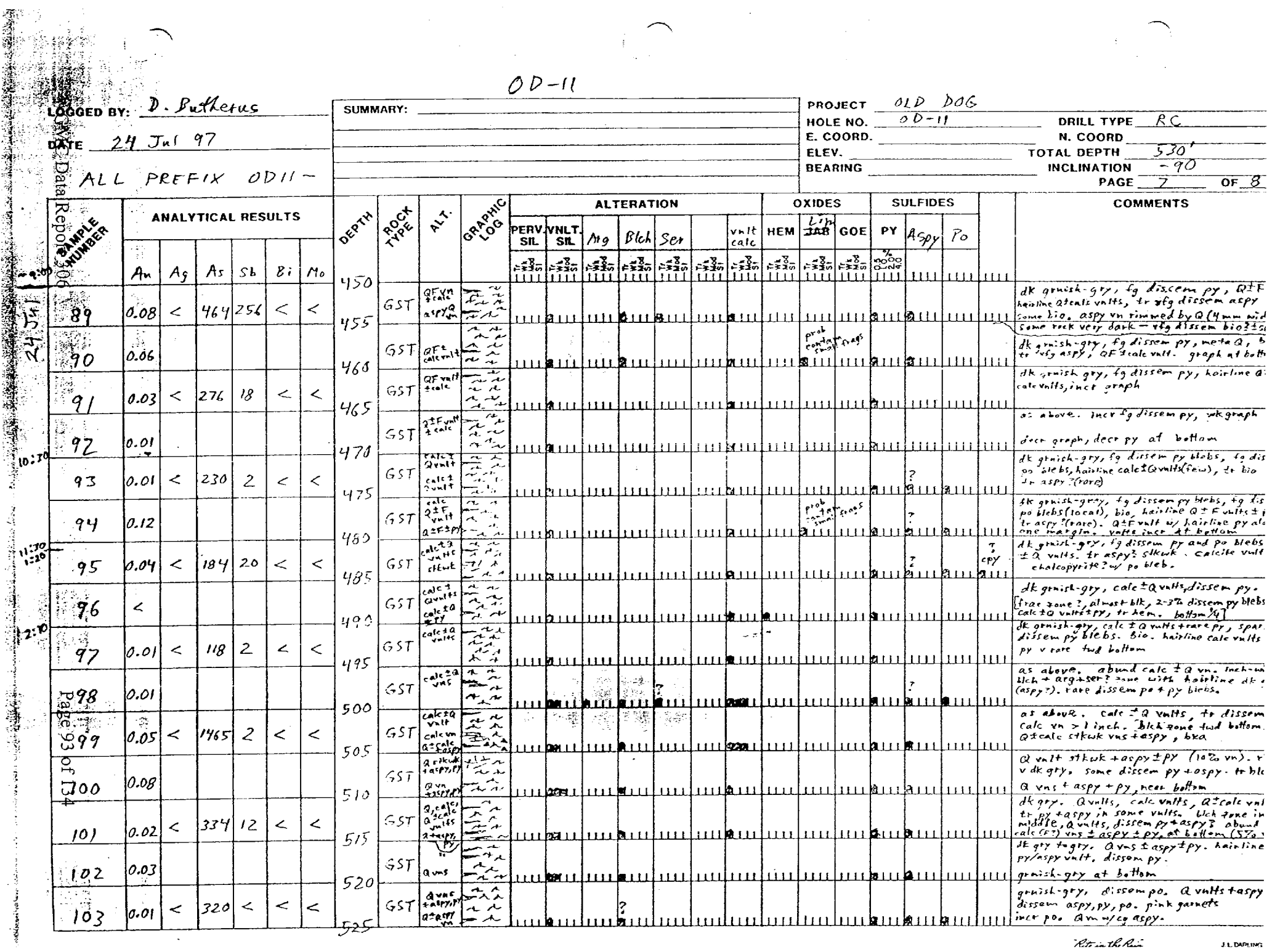




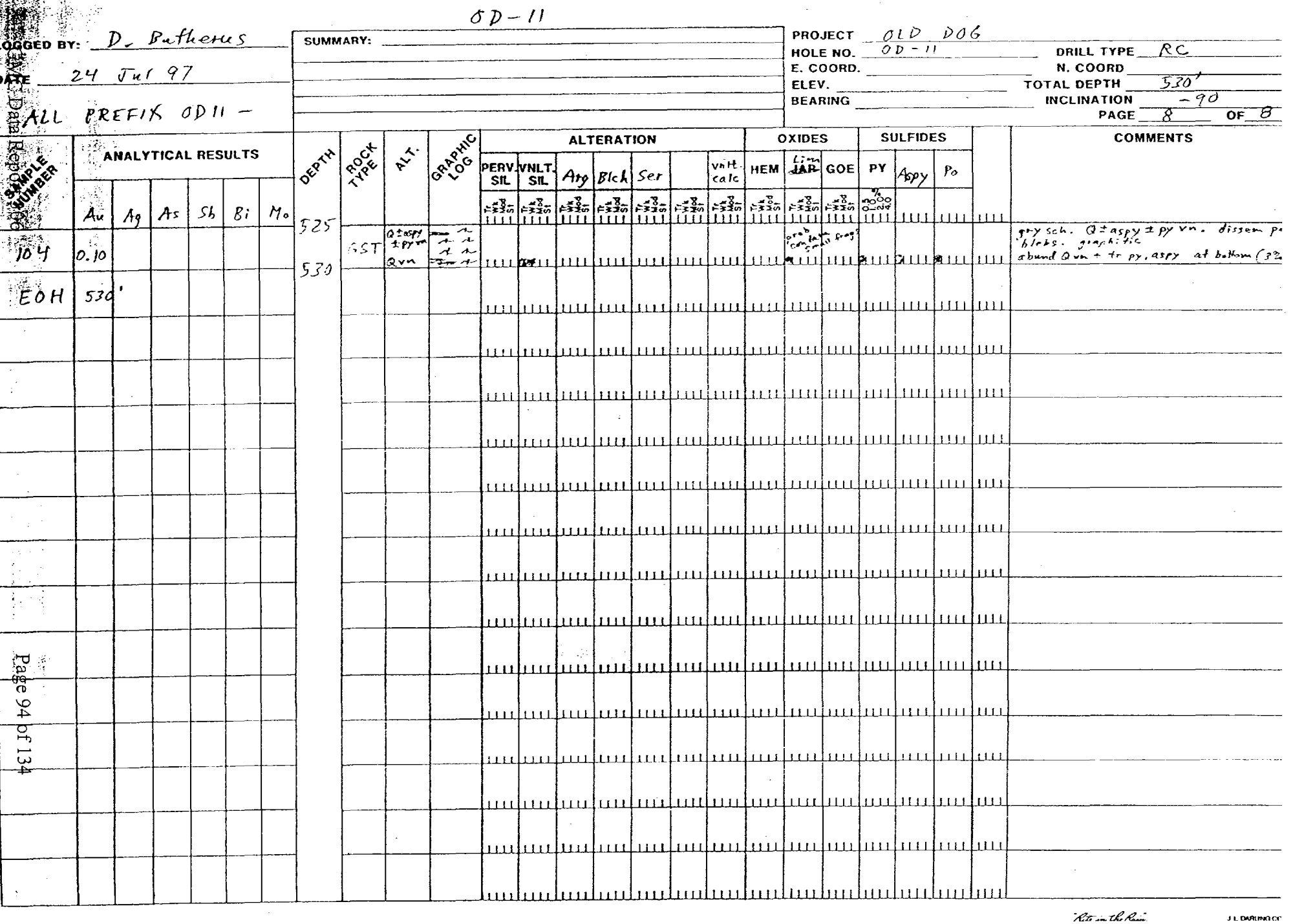




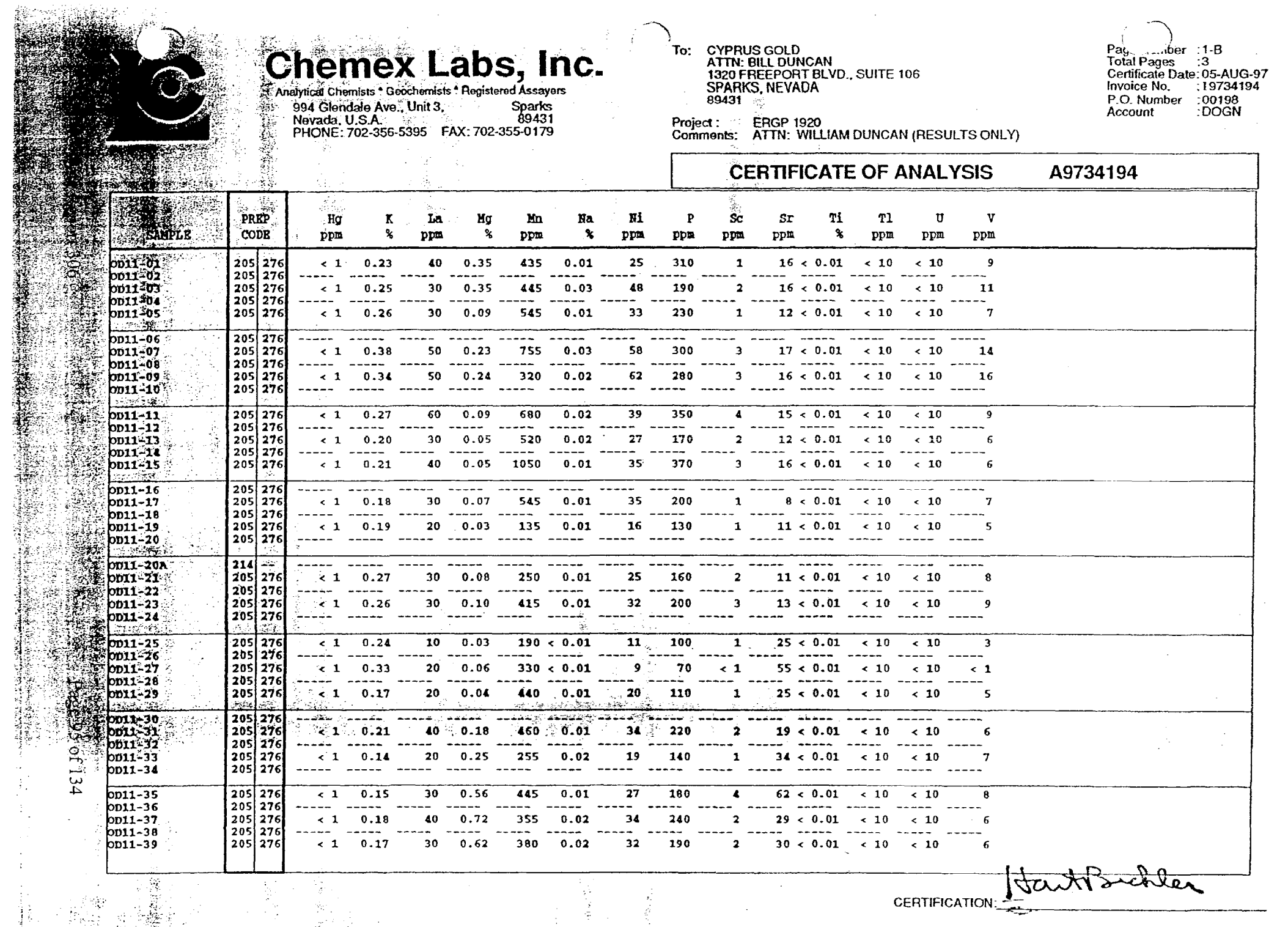




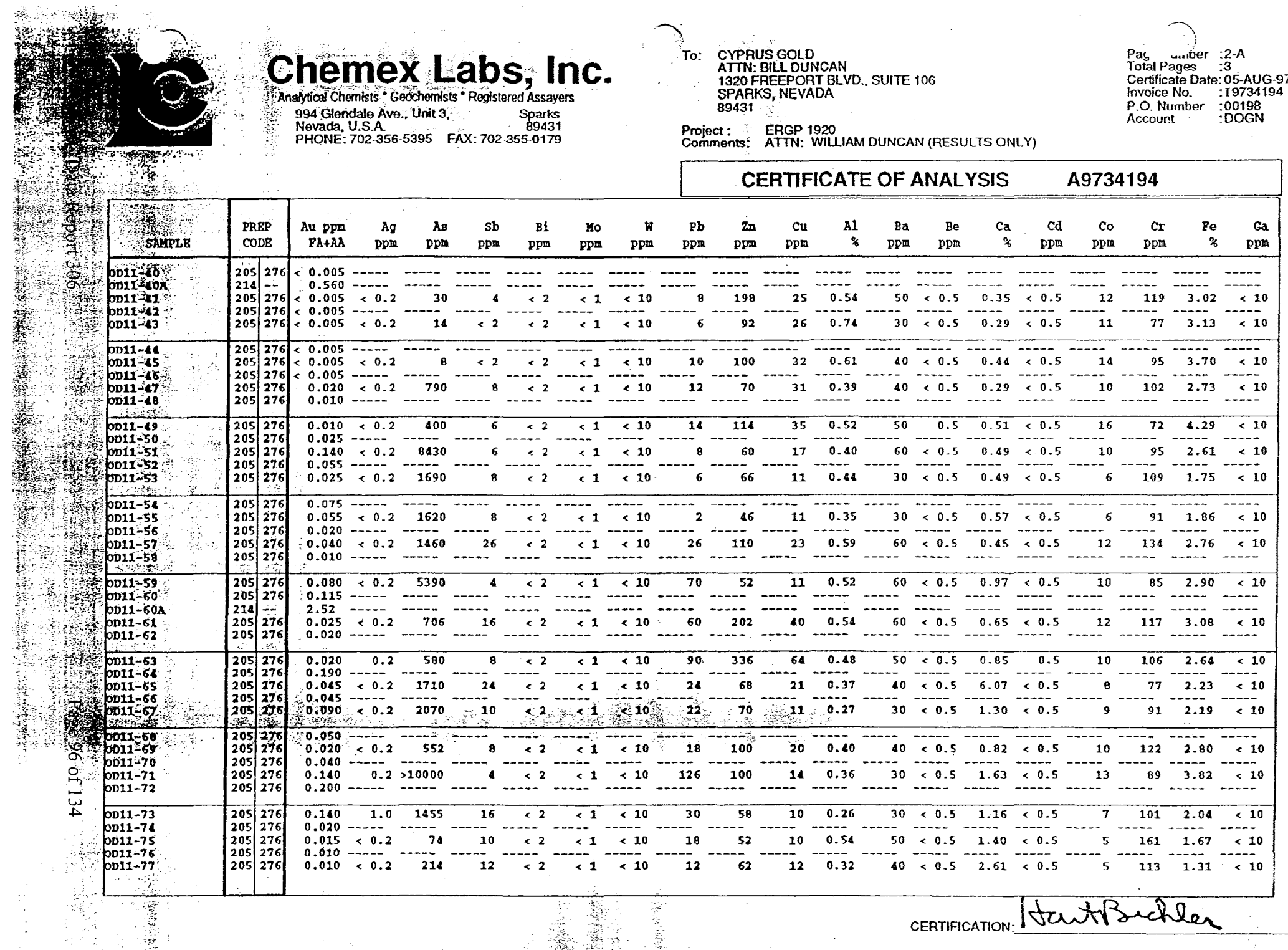




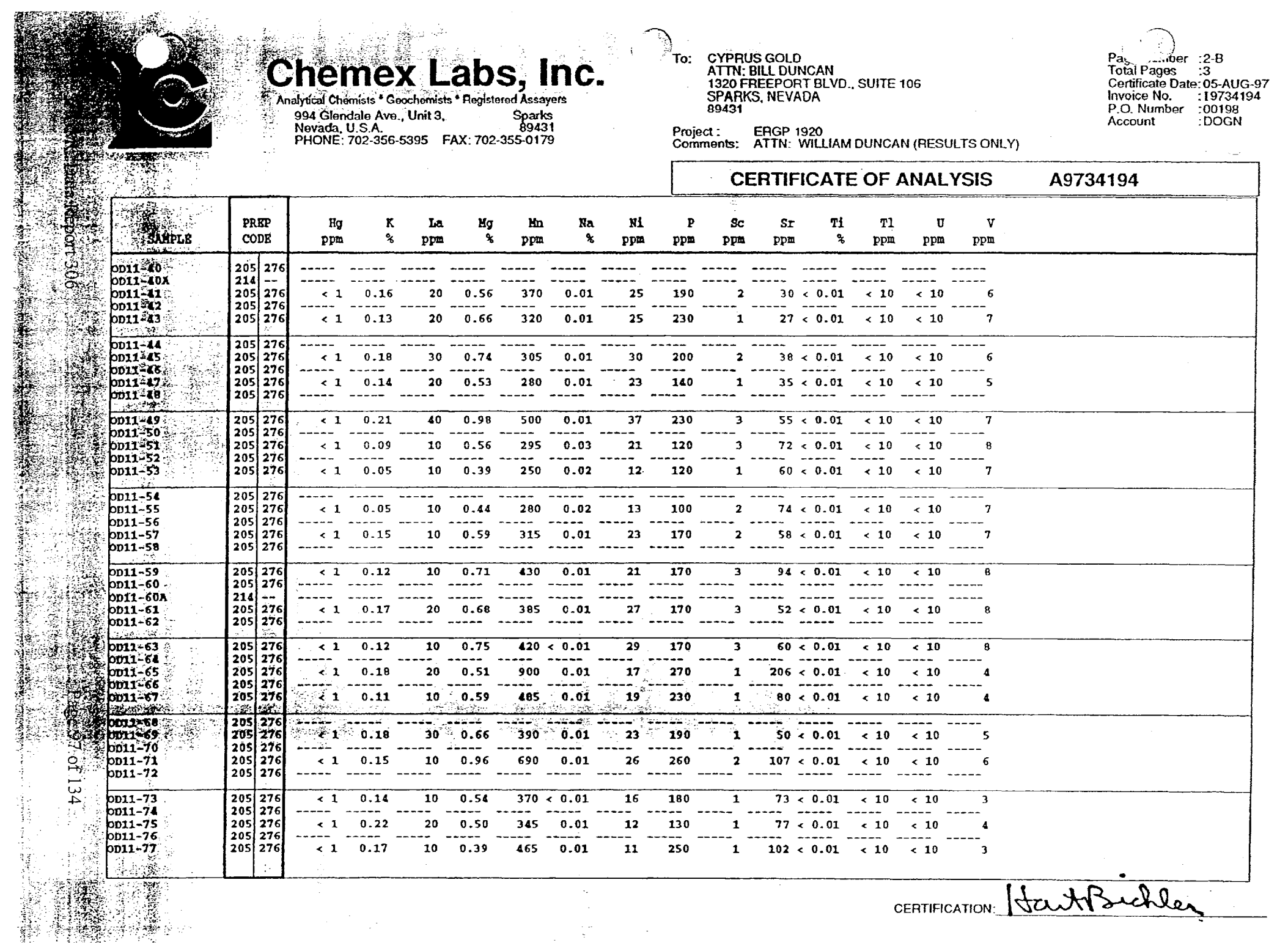




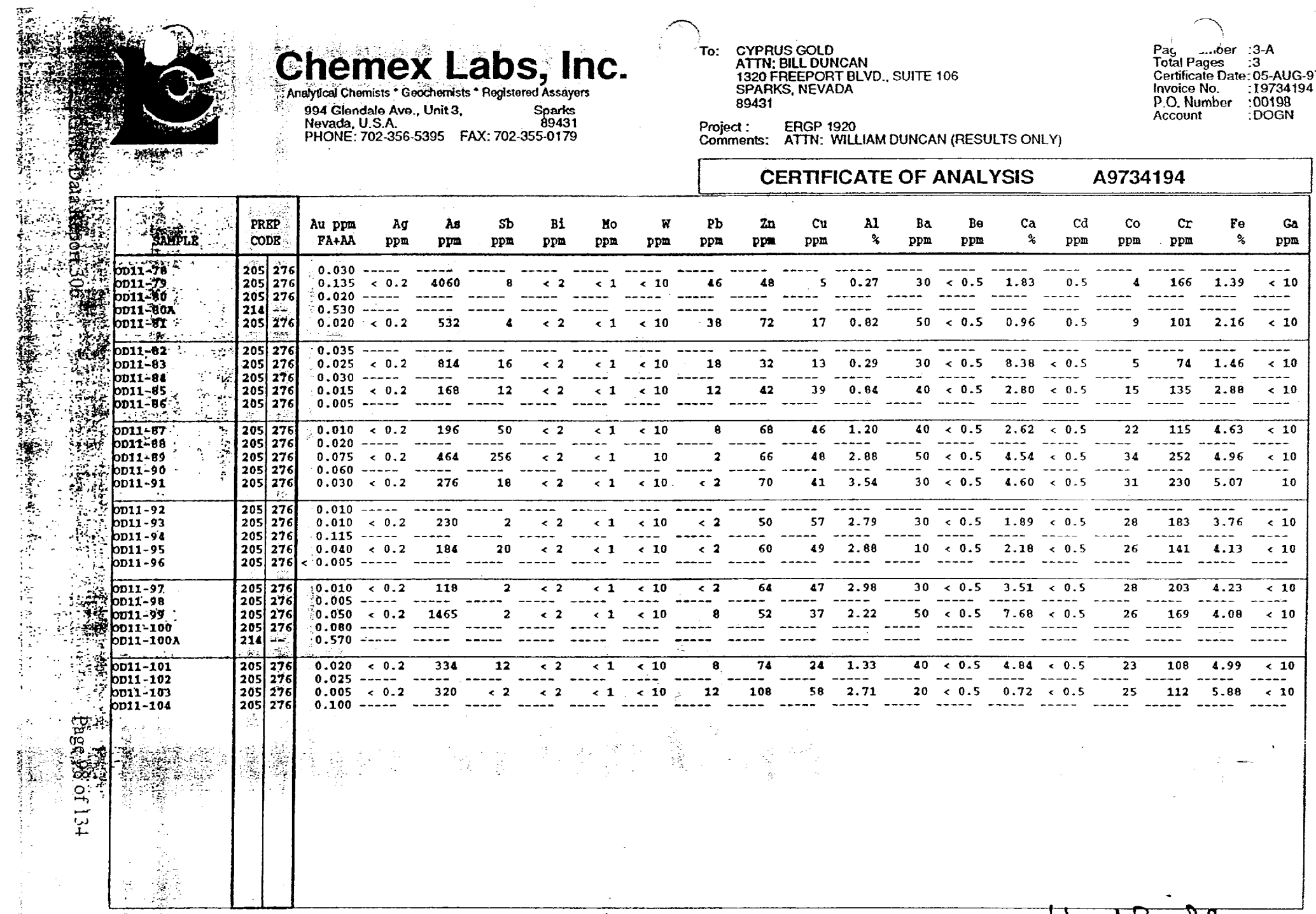




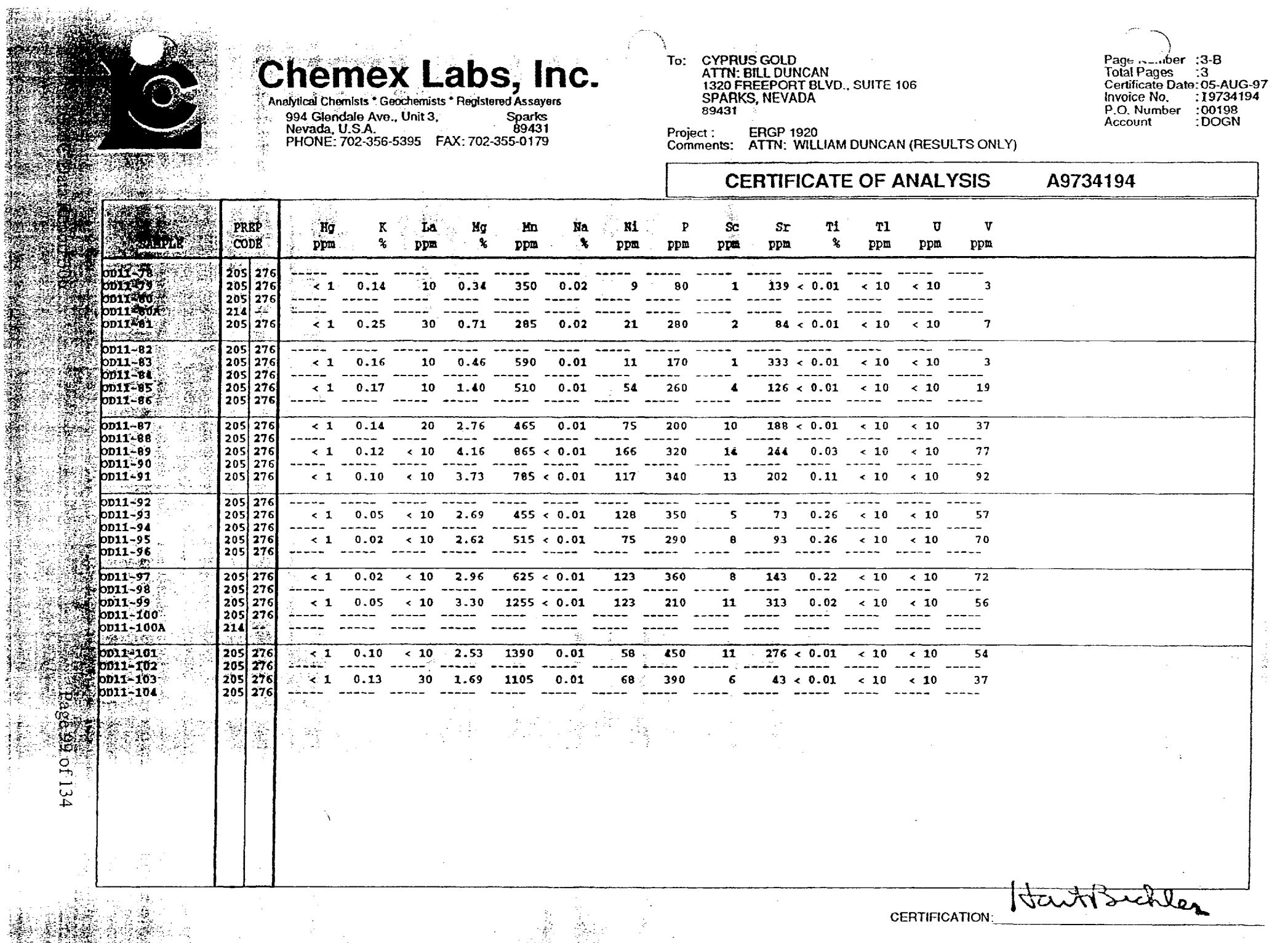




\title{
OLD DOG MINING CLAIMS \\ Fairbanks Mining District \\ Fairbanks, Alaska
}

\author{
Report prepared by \\ Roger McPherson, owner \\ 1042 Gilmore Street \\ Fairbanks, Alaska 99701 \\ (907) 457-2882
}

\section{INTRODUCTION}

Gold mineralization in the Fairbanks District is closely related to intrusives and a metavolcanic sequence of schists. The Old Dog claims are situated in the "Cleary Sequence," the gold-bearing metavolcanic schists, and there are four small exposures of intrusives containing gold, arsenic and stibnite. The claims drain into Treasure Creek, an historic gold placer several miles long. Adjacent claims have recently been explored by American Nickel and Copper Company (ANAC) for lode sources.

\section{LOCATION AND DESCRIPTION}

Old Dog claims (16 claims of 40 acres each, State of Alaska lease-hold locations) are located 15 miles north of Fairbanks on a ridge and slope to the west of Treasure Creek. Access is via Old Murphy Dome Road off the Elliott Highway, a distance of 8 miles. A four-wheel drive track connects Old Murphy Dome Road to the claims. Recent exploration work by ANAC improved the track, although the last half mile is rutted from erosion.

These gold lode claims are located on flat terrain on the ridgetop, and on a gentle slope going down to Treasure Creek. Scrub spruce and stands of aspen characterize the ridgetop. On the slope the scrub spruce give way to large stands of birch and spruce as drainage and soil cover increase. Loess thickens downslope, masking bedrock features.

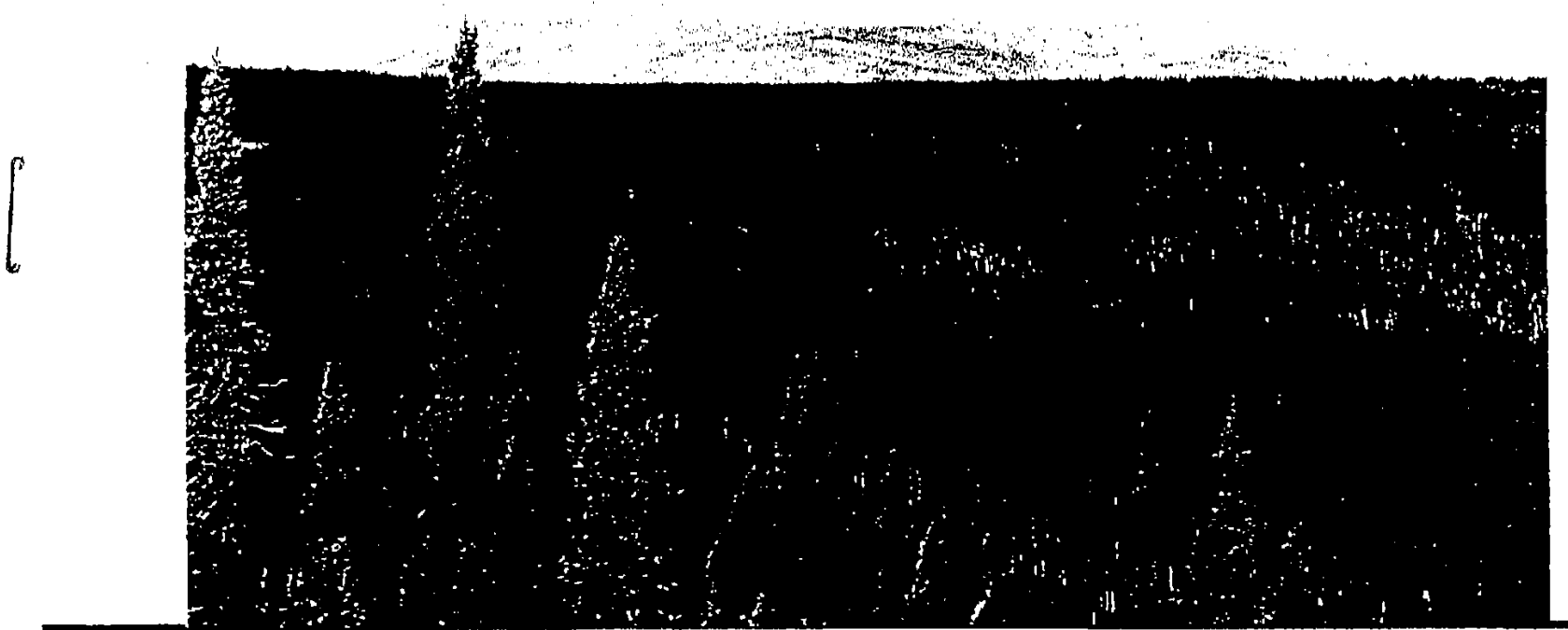

The phtograph shows the ANAC exploration area over the larger, unroofed intrusive (road zig-zagging down the hillside, left), and the Old Dog claims along the ridge (center and right) and slope above Treasure Creek. The access road is located on the ridge. 


\section{HISTORY}

Downstream from the lode area the productive Treasure Creek and Vault Creek placer was worked in the early 1900s. Becasue of the depth of overburden, no dredging was done. Winter drift mining continues today. L.M. Prindle described the placers:

The auriferous deposits on Vault Creek extend from No.9 claim above discovery to the mouth of the valley, a distance of 6 miles; on Treasure Creek to a point 3 miles above the mouth... The productive gravels have widths ranging from 25 to 225 feet, a maximum thickness of about 7 feet, and values ranging from 50 cents to $\$ 7$ to the square foot of bedrock.... The gold is in general coarse, very little flour or flaky gold being found.'

All of the old tailings piles examined in Treasure Creek contain light-colored igneous rocks simiar to the igneous exposures in the ANAC and Old Dog claims.

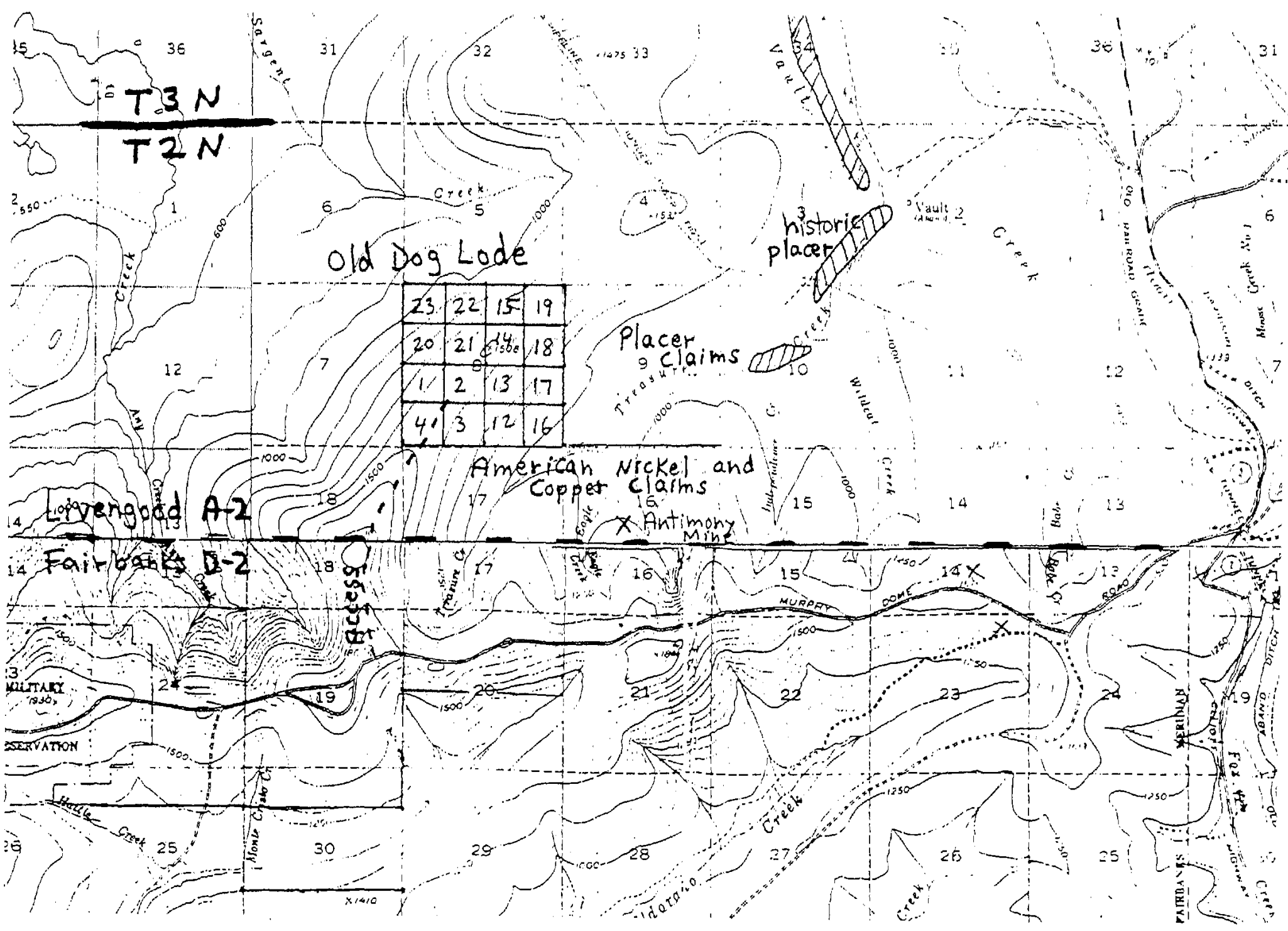

The map shows the location of Old Dog, ANAC, and placer claims as well as the historic placers and access routes.

' Prindle, L.M. U.S.G.S. Bulletin 525. 1913. Page 101.

2 Page 
The Scrafford antimony mine above Eagle Creek, a tributary of Treasure Creek, consisted of massive stibnite in a shear zone striking east-west and dipping 55 degrees south. Antimony was mined during World War I and in 1926-27. Production figures estimate over 2 million pounds of antimony were produced from open cuts. This large claim block was leased to American Nickel and Copper:

ANAC also conducted geophysical, geochemical, and geological surveys and completed 833 meters (2,733 feet) of diamond drilling at the Eagle Creek prospect off Murphy Dome Road, where gold-bearing veins are hosted in granite porphyry igneous bodies. ${ }^{2}$

\section{ECONOMIC GEOLOGY}

Four small intrusives are exposed in four claims. Arsenic halos characterize each exposure and gold values are elevated where granite contacts schist. Stibnite values also occur, but are not directly related to gold mineralization.

Two initial rock samples from the northwest intrusive had gold values of 18 and $636 \mathrm{ppb}$ and arsenic values of 1235 and $1057 \mathrm{ppm}$ respectively. An extensive geochemical soil survey was undertaken over three years. Soil samples were taken from the "B" horizon and Bondar-Clegg did the assaying.

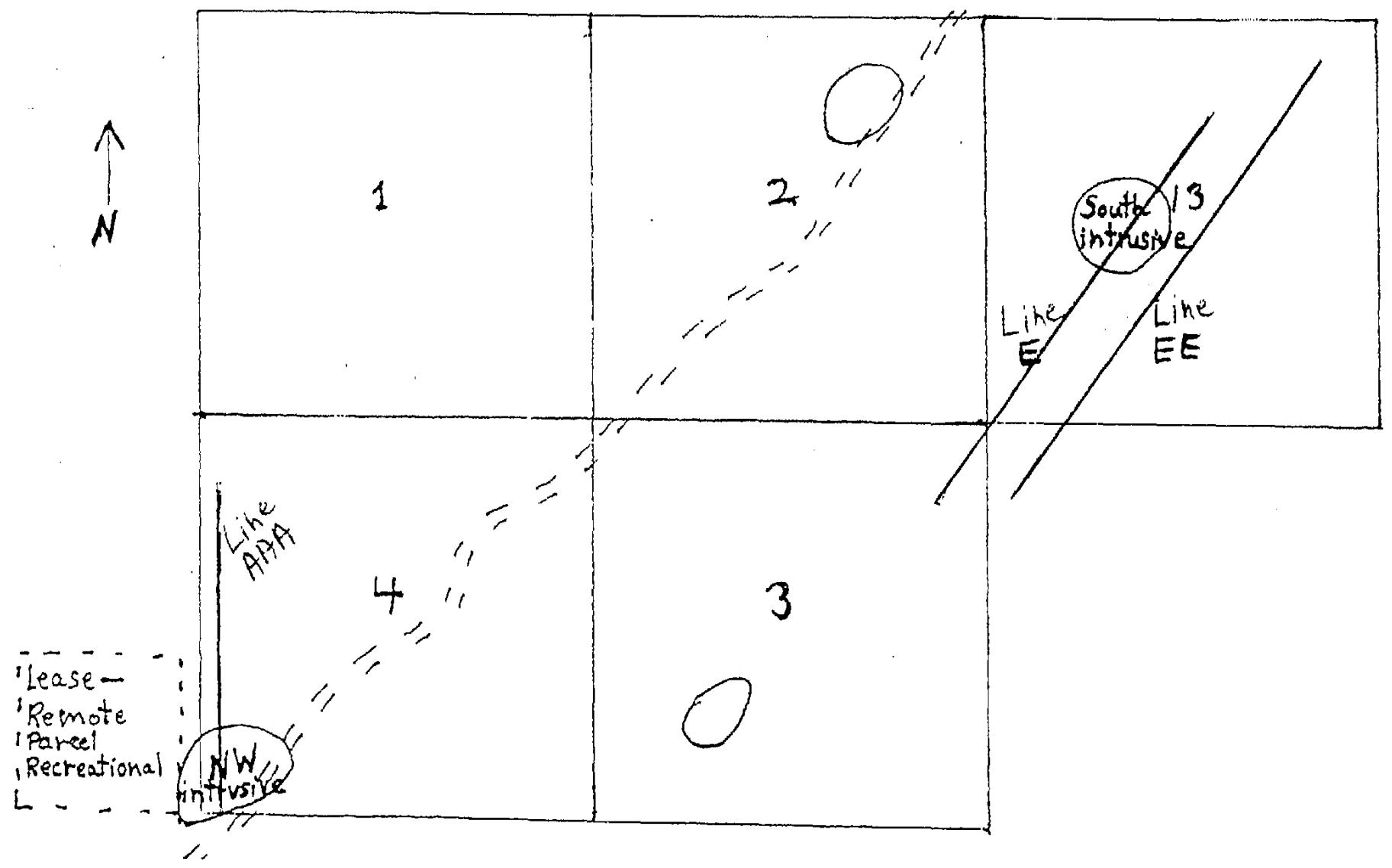

Sketch of claims which shows the intrusive locations and geochemical soll survey lines.

2 State of Alaska, Division of Geological and Geophysical Surveys. "Alaska's Mineral Industry in 1992," Page 9. 
The northwest intrusive, lying on the line between ANAC claims and a private recreation leasehold, is bleached and altered fine-grained to porphyritic rock with areas of small pyrite and arsenopyrite crystals. A bout 400 feet of the intrusive is exposed.

\section{Line AAA, Northwest Intrusive}

\begin{tabular}{|l|l|l|l|}
\hline Station & Au ppb & As ppm & Sb ppm \\
\hline 0 & 99 & 241 & 87.1 \\
\hline 50 & 68 & 160 & 58.6 \\
\hline 100 & 190 & 265 & 44.7 \\
\hline 150 & 66 & 102 & 27.2 \\
\hline 200 & 52 & 87 & 23.7 \\
\hline 250 & 34 & 64 & 21.8 \\
\hline 300 & 32 & 273 & 28.7 \\
\hline 350 & 27 & 190 & 13 \\
\hline 400 & 68 & 437 & 13 \\
\hline 450 & 19 & 102 & 6.6 \\
\hline 500 & 46 & 245 & 13 \\
\hline 550 & 120 & 173 & 8.9 \\
\hline 600 & 53 & 133 & 7.6 \\
\hline 650 & 57 & 121 & 6.5 \\
\hline 700 & 30 & 139 & 9.2 \\
\hline 750 & 190 & 139 & 6.7 \\
\hline 800 & 39 & 154 & 7.8 \\
\hline
\end{tabular}

\section{Northwest Intrusive, Line AAA}

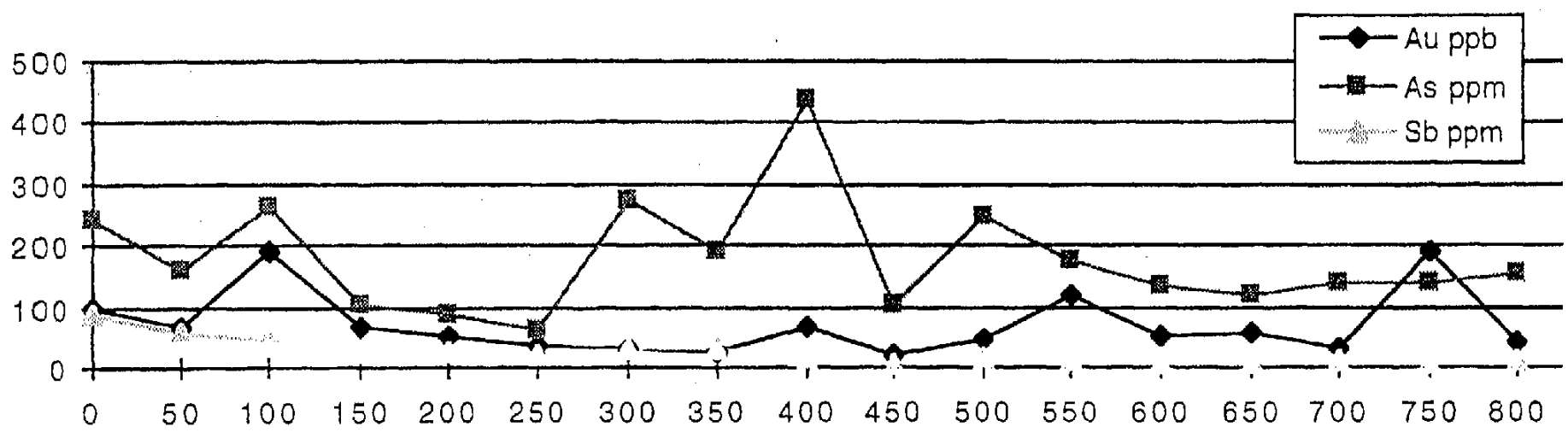

High arsenic values seem to correlate well with gold anomalies. The sharp spike at 400 feet was confirmed as a potential gold zone by additional soil surveys. However, this area leads into the private leasehold. The high gold values seem to support the concept of gold-bearing veins in the igneous body.

A concentration of stibnite near Stations 0-100 shows a close correlation with arsenic and gold, but this relationship is not consistent with other areas of the claims. While gold values drop off after Station 200 , the arsenic values show an increase. After Station 200 the granite is covered by schist, which permits arsenic halos but little migration of gold.

This is a flat lying to gentle downhill area. The shallow loess cover over the schist is frozen. 
The largest igneous exposure, the South intrusive (Lines $\mathrm{E}$ and $\mathrm{EE}$ ), again shows the gold and arsenic relationship. There is a small area of porphyritic intrusive exposed, but the area is largely covered with decomposed schist and loess. Arsenic halos in the schist and loess point to exploration targets.

South intrusive,Line E

\begin{tabular}{|c|c|c|c|}
\hline Station & Au ppb & As ppm & Sb ppm \\
\hline 950 & 64 & 240 & 34.2 \\
\hline 1000 & 130 & 349 & 47.8 \\
\hline 1050 & 150 & 360 & 41.7 \\
\hline 1100 & 210 & 408 & 61.4 \\
\hline 1150 & 200 & 308 & 63.1 \\
\hline 1200 & 60 & 176 & 84.5 \\
\hline 1250 & 43 & 162 & 126 \\
\hline 1300 & 30 & 121 & 89.3 \\
\hline 1350 & 13 & 92 & 49.3 \\
\hline 1400 & 27 & 159 & 73.2 \\
\hline 1450 & 28 & 133 & 44.1 \\
\hline 1500 & 25 & 220 & 20.6 \\
\hline 1550 & 25 & 167 & 12 \\
\hline 1600 & 41 & 219 & 14 \\
\hline 1650 & 30 & 194 & 8.9 \\
\hline 1700 & 43 & 275 & 10 \\
\hline 1750 & 67 & 244 & 7.4 \\
\hline 1800 & 420 & 319 & 21.4 \\
\hline 1850 & 36 & 223 & 14 \\
\hline 1900 & 47 & 221 & 8.5 \\
\hline 1950 & 46 & 295 & 14 \\
\hline 2000 & 52 & 238 & 15 \\
\hline
\end{tabular}

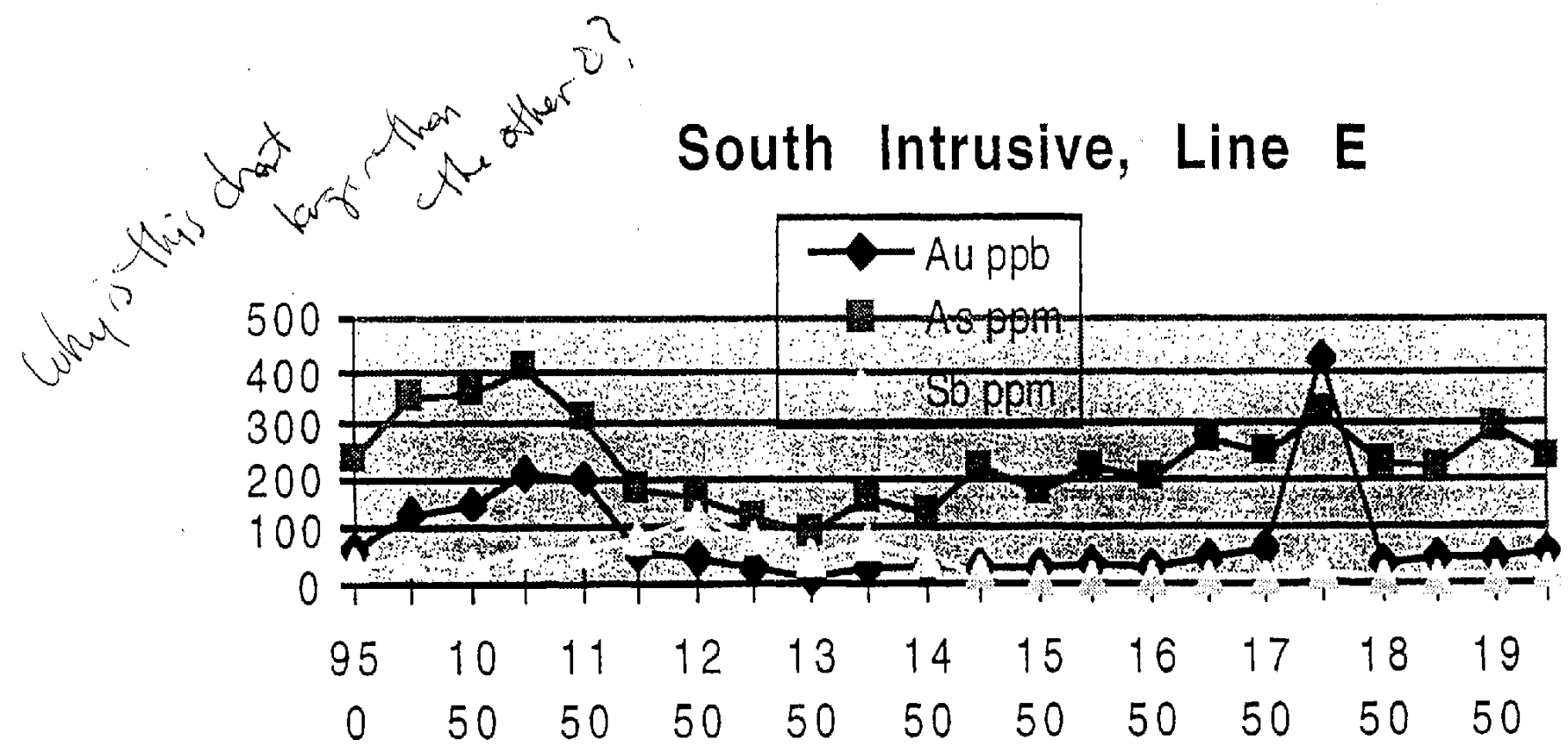


The other line over the vicinity of the South intrusive, Line EE, also shows the arsenic peaks coming through the schist and loess cover.

\section{Line EE, South Intrusive}

\begin{tabular}{|l|l|l|l|}
\hline Station & Au ppb & As ppm & Sb ppm \\
\hline 1150 & 20 & 148 & 58 \\
\hline 1200 & 27 & 94 & 33.8 \\
\hline 1250 & 22 & 160 & 26.2 \\
\hline 1300 & 25 & 144 & 15 \\
\hline 1350 & 43 & 271 & 16 \\
\hline 1400 & 48 & 288 & 12 \\
\hline 1450 & 28 & 230 & 10 \\
\hline 1500 & 36 & 235 & 11 \\
\hline 1550 & 78 & 273 & 11 \\
\hline 1600 & 36 & 169 & 7.9 \\
\hline 1650 & 33 & 185 & 8.7 \\
\hline 1700 & 70 & 290 & 11 \\
\hline 1750 & 26 & 165 & 11 \\
\hline 1800 & 54 & 226 & 11 \\
\hline 1850 & 32 & 183 & 8.9 \\
\hline 1900 & 34 & 193 & 10 \\
\hline 1950 & 22 & 101 & 7.2 \\
\hline 2000 & 16 & 97 & 5 \\
\hline 2050 & 21 & 196 & 9.2 \\
\hline 2100 & 17 & 100 & 6.1 \\
\hline 2150 & 33 & 241 & 12 \\
\hline 2200 & 26 & 210 & 13 \\
\hline 2250 & 84 & 182 & 7.5 \\
\hline 2300 & 57 & 138 & 7.5 \\
\hline 2350 & 11 & 108 & 8.1 \\
\hline 2400 & 22 & 148 & 5.2 \\
\hline & & & \\
\hline
\end{tabular}

\section{South Intrusive, Line EE}

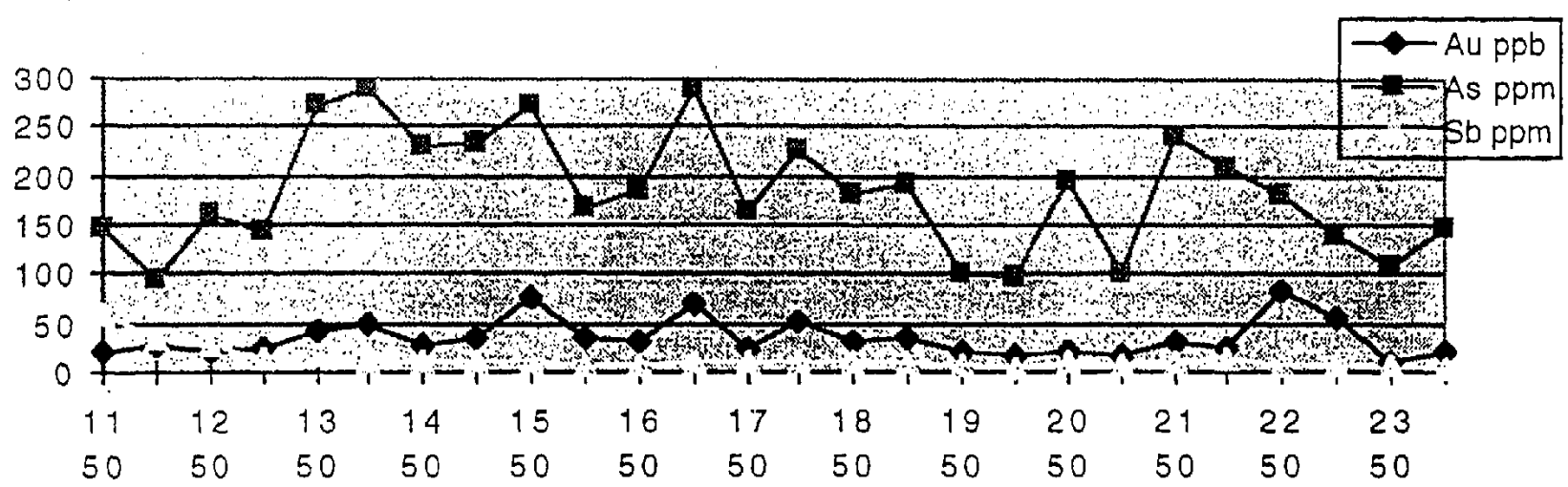


The soil sampling program shows arsenic anomalies which extend over a thousand feet and which point to deeper mineralization. These soil anomalies have the following characteristics:

- elevated arsenic (100 to $400 \mathrm{ppm}$ )

- direct correlation with arsenic and gold (As $>300 \mathrm{ppm}: \mathrm{Au}>100 \mathrm{ppb}$ )

- gold values exceeding $1000 \mathrm{ppb}$ (not included in this data)

- extensive schist and loess cover with arsenic halos

\section{SUMMARY}

Historic placer gold production from the Treasure and Vault Creek areas was extensive, and a lode source was never identified. Recent exploration by American Nickel and Copper focused on a largely exposed intrusive. The nearby Old Dog claims have small intrusives with widespread arsenic halos related to gold anomalies. Gold values as high as $1500 \mathrm{ppb}$ have been obtained from soil sampling. Intrusives and overlying schist on the Old Dog claims have a high potential for gold mineralization. 


\section{West Coast Sales Sales Call Summary}

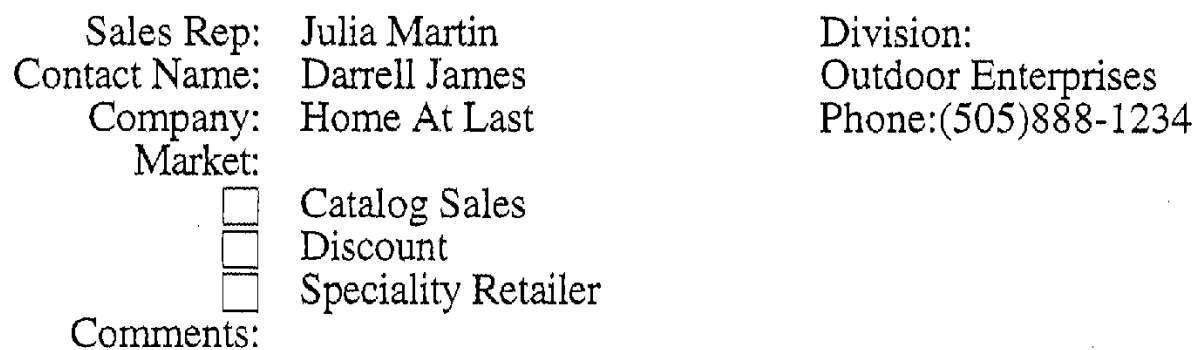

Roger McPherson 12-2-94

This was extremely frustrating. I created what I thought was a template of this information. However, the check boxes don't work when I click on them. The dtop-down list does't drop down. I went back over the chapter on this and my notes. It looks easy in class, but did't work out for me.

I saved the template to the HD so I could access it from the master list of templates. That's how I got this .

I did go back to the template and found that by locking it. I could find the drop-down menu, and get the boxes to be checked.

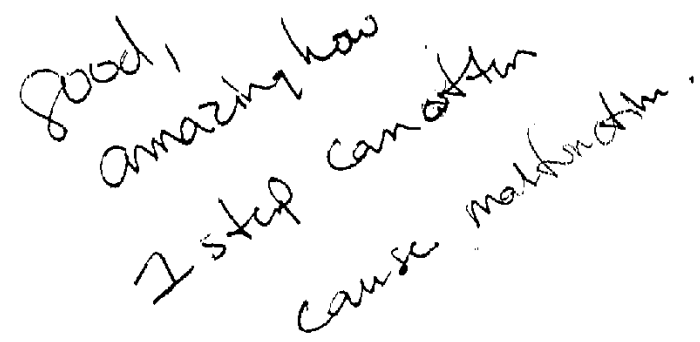


Location and Description

0ld Dog claims $(19$ claims of 40 acres each, State of Alaska leasehold locations) are located 15 miles north of Fairbanks on a ridge and slope to the west of Treasure Creek. Access is via 01d Murphy Dome Road off the Elliott Highway, a distance of 5 miles. A fourwheel drive track connects. Old Murphy Dome Road to the claims. Recent mining activity improved this road, although the last one-half mile is rutted from erosion of the steep slope. Access is also possible by four-wheeler via the TAPS road to Vault and Treasure Creeks, along the pipeline right-of-way to the ridgetop, and along a four-wheeler trail which connects with the ridgetop road. Alyeska Security grants a yearly permit to utilize this route for exploration purposes. All of the ridgetop has a platted right-of-way, extending from old Murphy Dome Road to the TAPS pipeline.

These lode claims are located on flat terrain on the ridgetop, and on a gentle slope going down to Treasure creek. Scrub spruce and stands of aspen characterize the ridgetop. On the slope scrub apruce give way to large birch and spruce as drainage and soil cover increase. Loess thickens half-way down the slope, masking bedrock features.

Previous prospecting is evident from a shallow pit in the intrusive, but no effort was expended. An old fallen in cabin on the northeastern part of the claims in a deep loess area could indicate a prospect shaft but no tailings are evident.

The intrusive exposure was sampled in 1988 and found to have gold and silver values as well as high arsenic. Magnetometer. work defined a magnetic anomaly a mile northeast of the intrusive. An iron-rich seepage arsa was discovered downslope to the northeast. The location of the historic placer on Treasure and varlt creeks foints to an upstream source in the vicinity of the 0!d Dog claims. 
iistory

The productive Vault and Treasure Creek placers were among those worked in the early 1900's. Because of the depth of overburden, no dredging was done. Drift mining continues today using declines and mechanized haulage. In USGS Bulletin 525 in 1913 L.M. Prindle described the placers:

The auriferous deposits on vault creek exterd from No.9 claim above discovery to the mouth of the valley; a distance of 6 miles; on Treasure creek to a point 3 miles above the mouth; on wildcat for about one-half mile above its mouth. on vault Creek above Treasure Creek, howover, productive gravels have been found at only one locality, and on wildcat Creek the deposits so far developed are of low grade. The worls on Ireasure creek also indicates interruption of gold deposition. The productive gravels have widths ranging from 25 to 225 feet, a maximum thickness of about 7 feet, and values ranging from 50 cents to $\$ 7$ to the square foot of bedrock.... The gold is in general coarse, very lit.tle flour or flaky gold being found. (p.101)

Don Read, presently drift mining Treasure Creek, reports no magnetite or granitio rocks in the gravels.

On the accompanying map, Prindle's location of the productive placer areas is shown. The placer channel is located to the east of presentday Vault Creek, a typical situation in the Fairbanks area where uplift and pleistocene loess and muck obscure the old creek channels. However, where the placer extends upstream into Treasure Creek, it crosses to the western side of the valley and ends before reaching the head of the valley.

The lode deposits mentioned by Prindle include the wel1-known scrafford antimony mine (inactive) and an unknown gold lode:

In the basin of the first tributary of Treasure Creek from the south, west of Independence Creek, two lodes have been exploited, but according to available reports no considerable amount of development work has been done. Near the mouth of this creek [Eagle Creek] on the eastern slope of the valley, a gold lode is renorted to have been located, and south of it, near the head of the basin, a lode carrying mainly stibnite was found. Specimens of the ore from both localities were seen and appear to be of high grade. Some silver minerals are reported to 
occur in the lode, but their composition was not determined. (p.196)

The Scrafford property is presently being explored by American Copper and Niclel. Located in the mineralized volcanic-sedimentary sequence identified as the "Cleary sequence" in the Fairbanks District, the Scrafford mine consists of massive stibnite in a shear zone striking east-west and dipping $55^{\circ}-60^{\circ}$ South. Heavily nxidized znnes contain secondary oxides, and assays of chip and channel samples show gold and silver along with the stibnite.

Preliminary assay results of chtp and channel samples

\begin{tabular}{|c|c|c|c|c|c|c|c|}
\hline Sample & Length of & & & Ele & 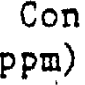 & cat1 & \\
\hline Number & channel ( $f t)$ & $\mathrm{Au}$ & $\mathrm{Ag}$ & $\mathrm{Cu}$ & $\mathrm{Pb}$ & $\mathrm{z} n$ & Sb \\
\hline 225 & 4 & 0.87 & 0.4 & 64 & 10 & 34 & 11,950 \\
\hline 226 & 4 & 2.1 & 0.4 & 139 & 8 & 25 & 11,900 \\
\hline 227 & 4 & 0.75 & 0.3 & 77 & 28 & 97 & 227 \\
\hline 228 & 3 & 0.98 & 0.7 & 158 & 5 & 19 & 115,000 \\
\hline 229 & 3.5 & 1.92 & 0.4 & 159 & 10 & 6 & 86,000 \\
\hline 240 & 1.5 & 0.01 & 0.1 & 83 & 20 & 96 & 90 \\
\hline 241 & 2 & 1.41 & 0.2 & 104 & 11 & 44 & 38 \\
\hline 242 & 4 & 3.06 & 1.3 & 93 & 110 & 193 & 379 \\
\hline 243 & 1.5 & 5.70 & 0.6 & 92 & 25 & 29 & 13,500 \\
\hline 244 & 1 & 1.41 & 0.1 & 77 & 12 & 41 & 100 \\
\hline 245 & 4 & 0.01 & 0.1 & 59 & 22 & 60 & 55 \\
\hline 247 & 2 & 0.01 & 0.0 & 70 & 11 & 50 & 38 \\
\hline 475 & 2.5 & 0.01 & 0.0 & 66 & 15 & 68 & 1,980 \\
\hline 495 & 3 & 0.10 & 0.1 & 68 & 15 & 102 & 472 \\
\hline
\end{tabular}

(From, Robinson, M.S. and Bundtzen, T.K. 1982. "Geology of the Scrafford Antimony-gold lode prospect, Fairbanks Mining District Alaska." Alaska open-file Report 173, State of Alaska, Dept. of Natural Resources, Div. of Geological and Geophysical Surveys)

Antimony was mined during world War $I$ and in 1926-27. Production figures estimate over 2 million pounds of antimony were produced from open cuts. 


\section{Economic Geology}

A small intrusive ( 300 feet in surface diameter) is exposed on the ridgetop at the southern limit of the 01d Dog claims, Pyrite and arsenopyrite crystals are evident in a fine-grained alaskite. Quartz phenocrysts up to $4 \mathrm{~mm}$ occur; one phase of the intrusive is almost entirely quartz. Exposed rocks carry 30 to 60 ppm stibnite and 90 to $1950 \mathrm{ppm}$ arsenio. Two samples assayed 140 and $636 \mathrm{ppb}$ gold, and one sample contained .9 ppm silven. This intrusive appears to be a late differentiate, hydrothermally altered by low temperature mineralized fluids. No contact effects are seen in the enolosing schist. Magnetometer surveys across the intrusive do not find any differences between the schist and the intrusive.

The four-wheel drive access roat crosses the intrusive. Part of the intrusive is located on adjojning claims under the control of American Copper and rickel.

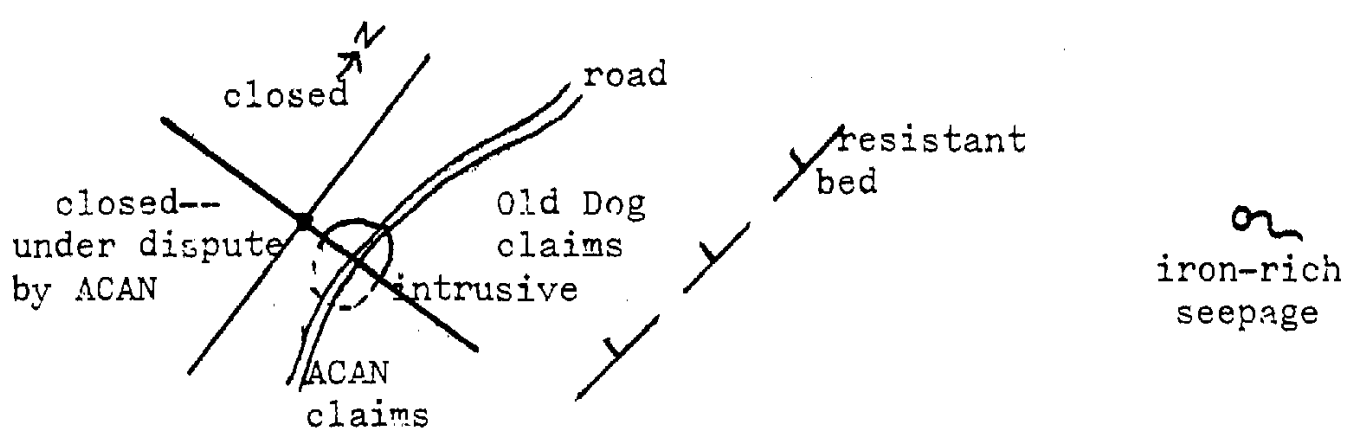

Country rock is quartz-mica-schist and micaceous schist. A resism tant bed downslone to the east causes a steep slope break which generally parallels the orientation of the ridge.

Downslope three-quarters of a mile from the intrusive to the ENE a smail irnn-rich seepage was discovered in the loess. Schist occurs approximately 600 feet upslope. This eluvial area would have a very small detrital area tn draw from. Since iron concretions fix some elements; stream sediments of the iron-rich material were dried and assayed and indicated $14 \mathrm{ppb}$ gold, $333 \mathrm{ppm}$ arsenic, and $3.4 \mathrm{ppm}$ stibnite. 
trated and found to have $51 \mathrm{ppb}$ gold, $50 \mathrm{ppm}$ arsenic, $13 \mathrm{ppm}$ stibnite, and $11 \mathrm{ppm}$ tungsten. The iron-rich sediments fixed arsenic, while the heavies were detected by the pan concentrates. The presence of tungsten is particularly significant since scheelite occurs in many placers in the Fairbanks District:

Four types of scheelite deposits have been found at scattered intervals along the southern side of the Pedro Dnme area in a belt of gold-tungsten mineralization which extends about N. $65^{\circ} \mathrm{E}$. .... distance of about 8 miles. Scheelite occurs chiefly in gold quartz veins which cut thin crystalline lisestone beds, a few inches in thickness, or calcareousschist. (Byers, USGS Bul1.1024-I, 1957, p.206)

Scheelite nccurs in the cleary Hill mine, the largest lode-gold mine in the district, and is a minor constituent in other gold quartz veins.

In addition to the intrusive and iron-rich seep, reconnaissance magnetometer surveys of the claims located an oval magnetic anomaly (up to 200 gammas) a mile north of the intrusive on the ridge. The circular shape suggests an intrusive cupola at depth. No surface outcrop or alteration effects have been found. 


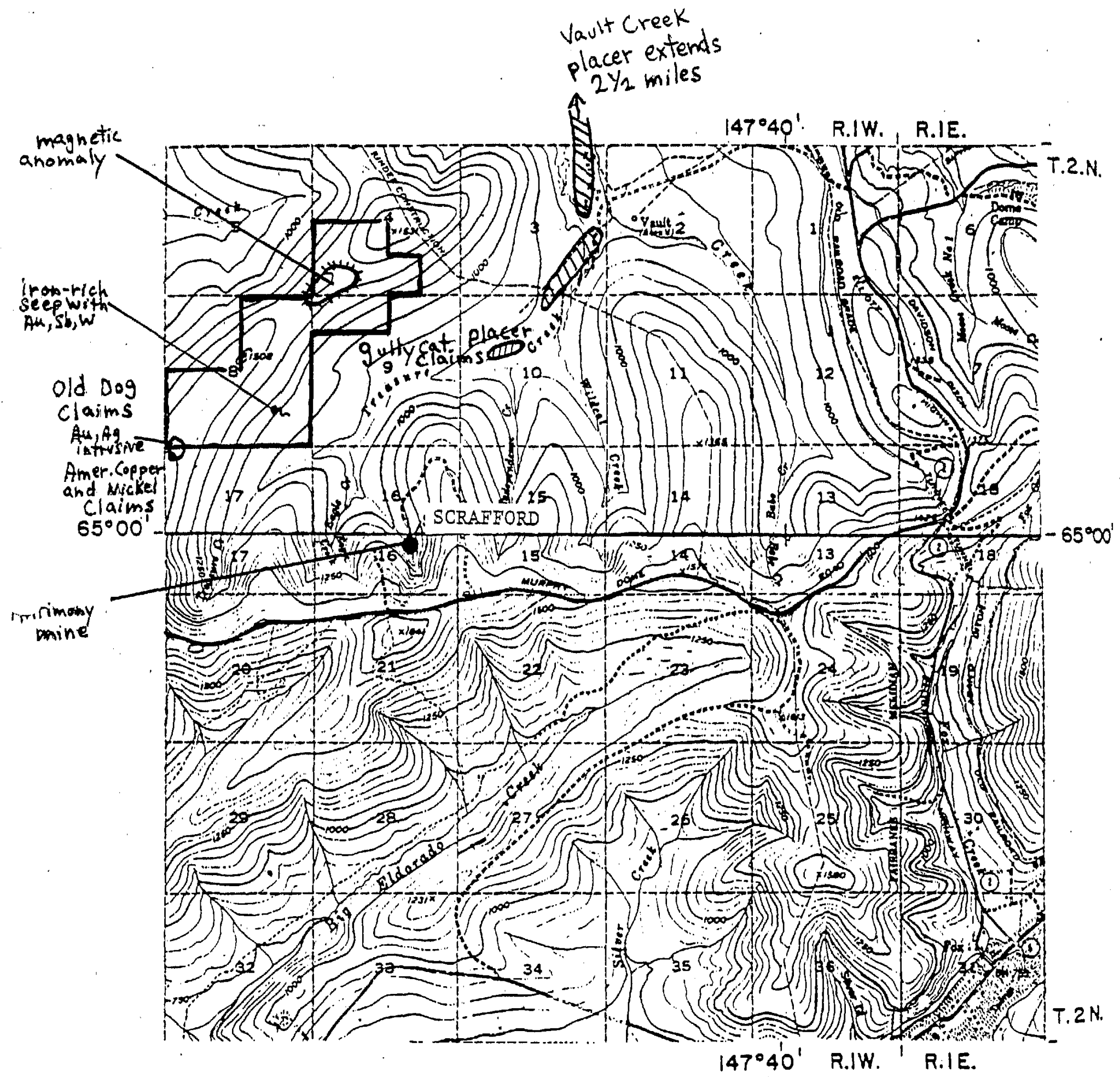

Base from U.S. Geological Survey Fairbanks D-2 (1954, revised 1975) and Livengood A-2 (1954) Quadrangles.

$$
\text { Scale } 1 \text { in. = } 1 \text { mi }
$$




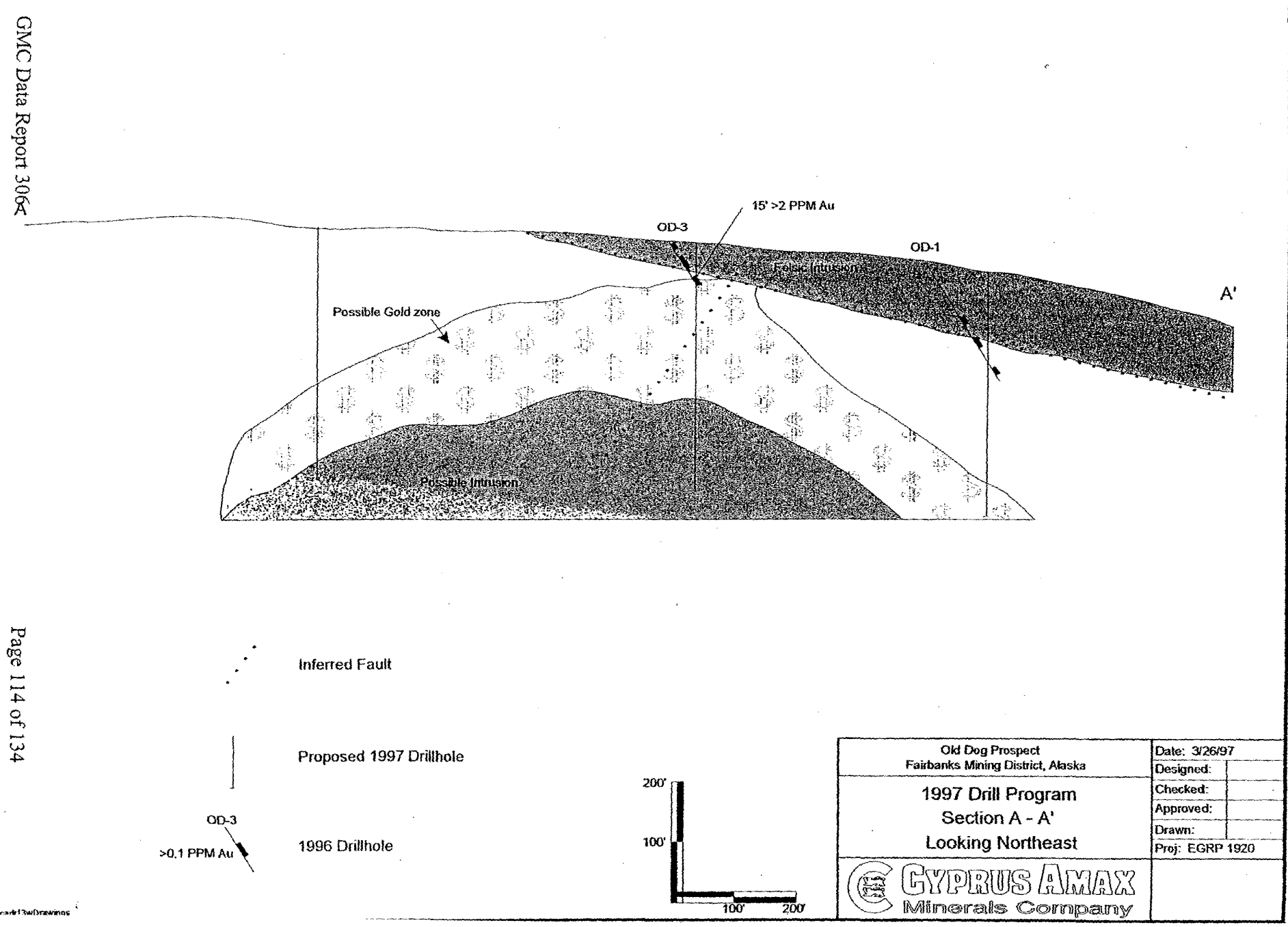



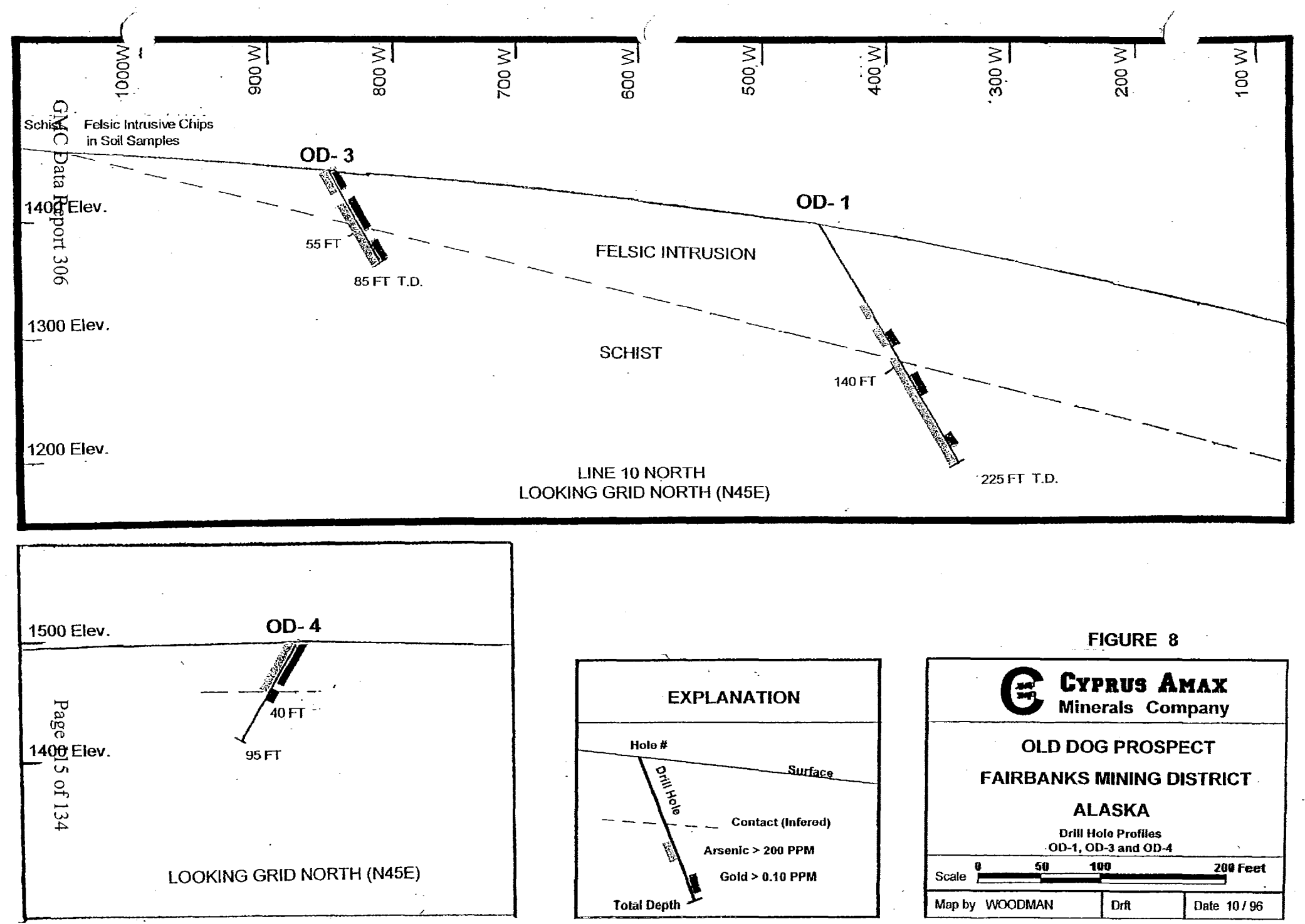

FIGURE 8

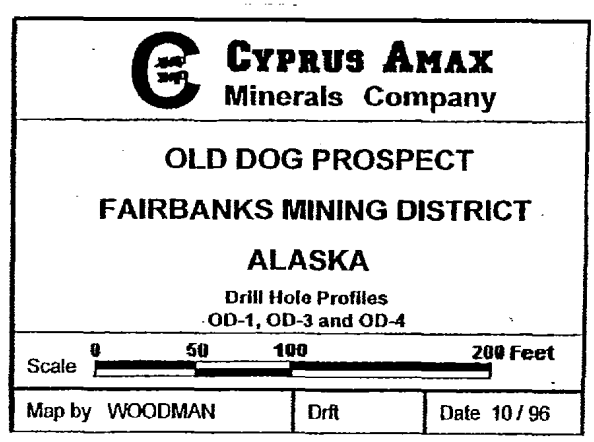




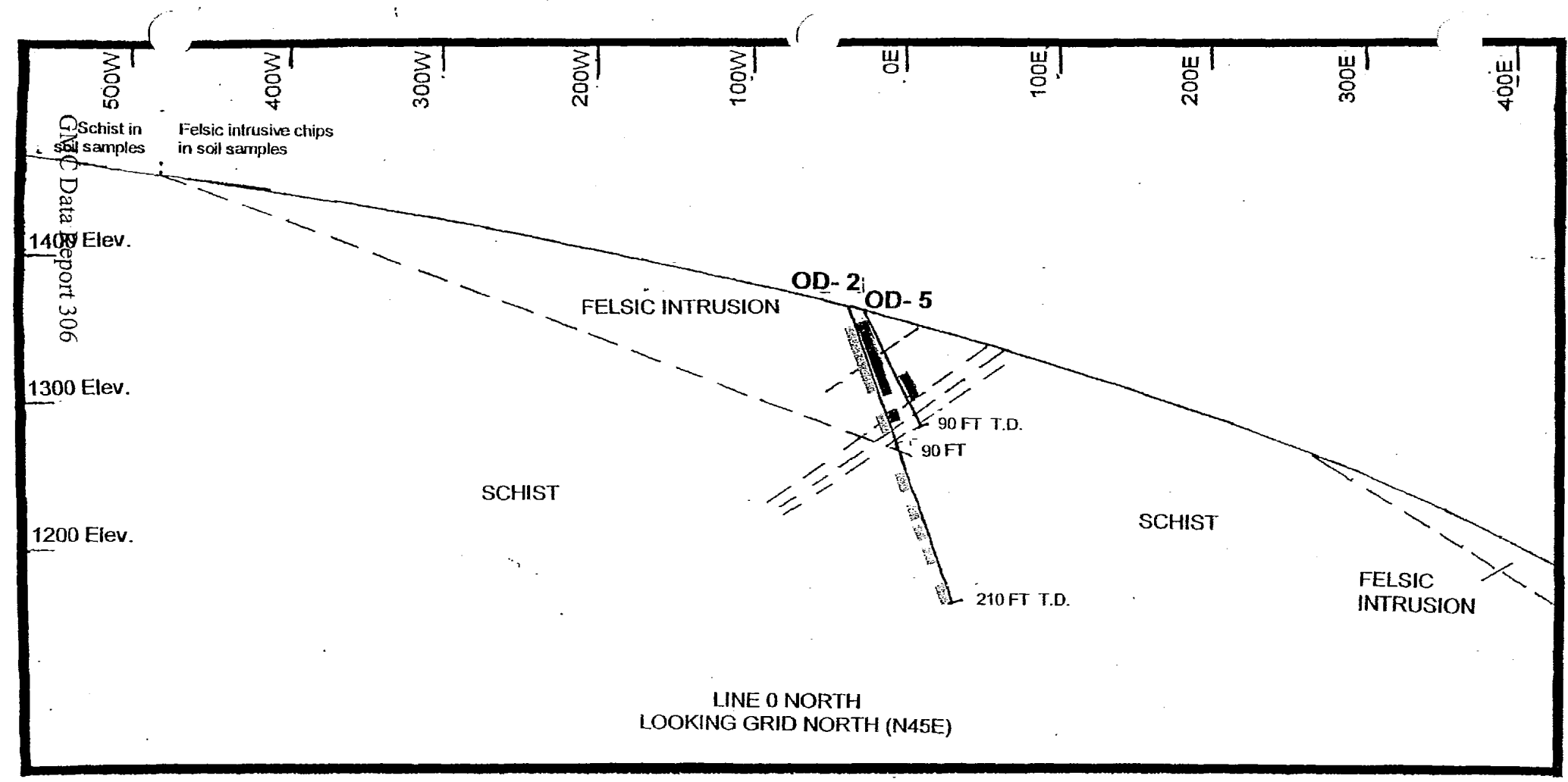

FIGURE 9

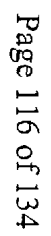

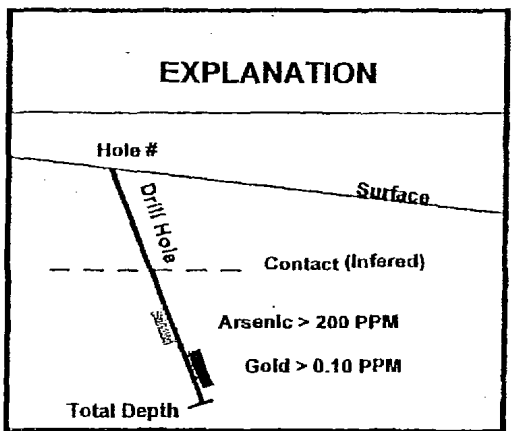

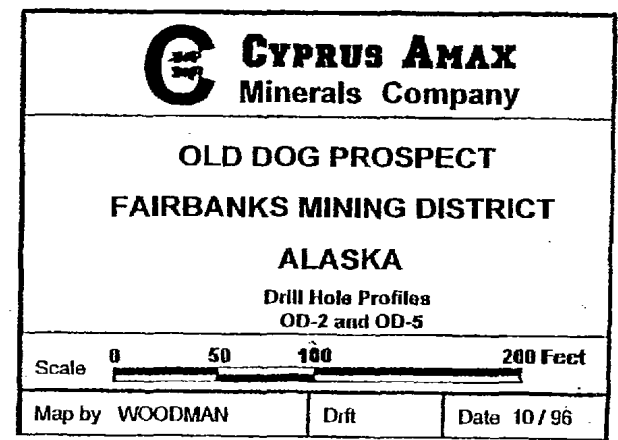




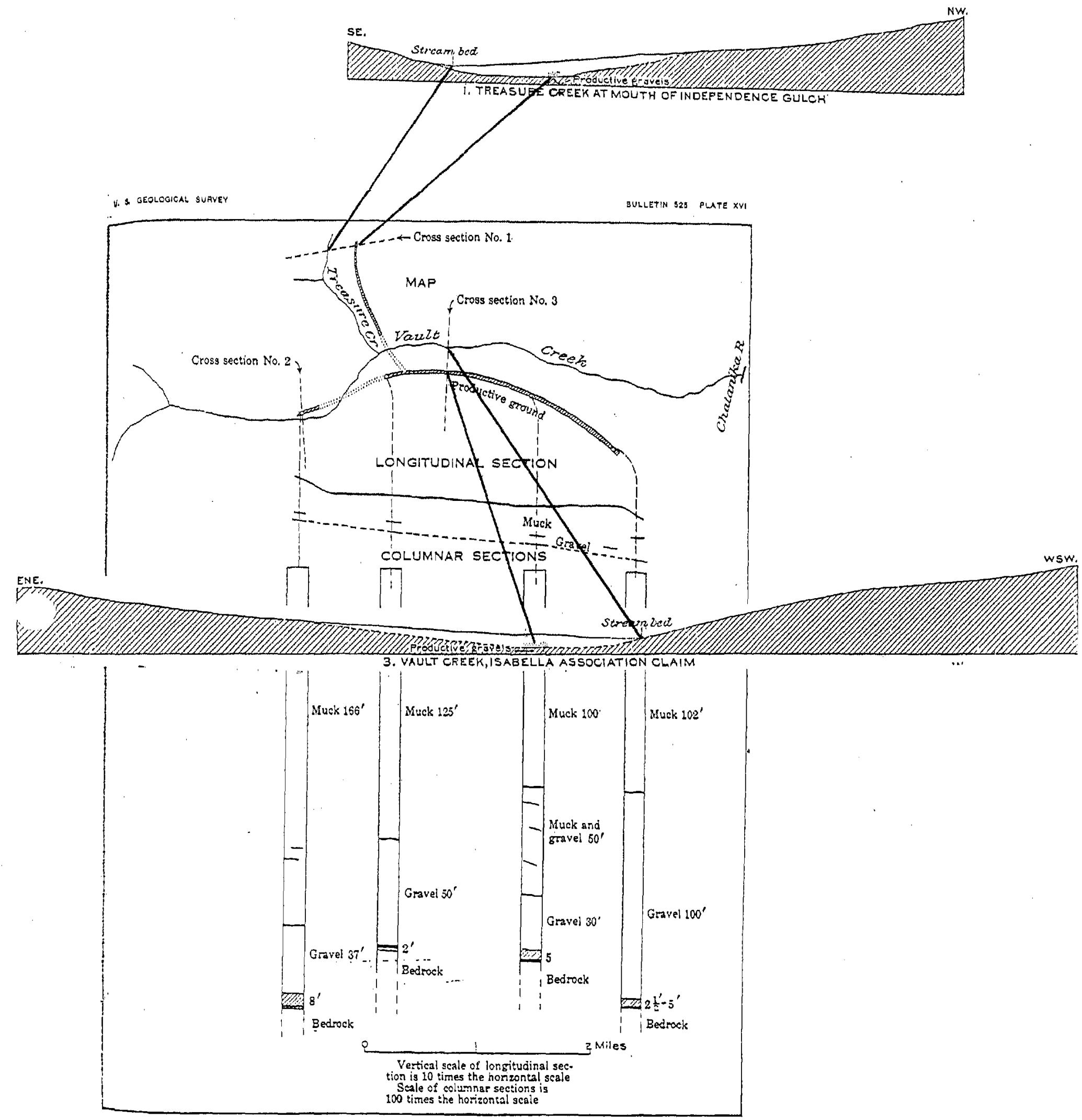

PROQUCTIVE GROUNO EXPLOITED ON YAULT CREEK,

Dashed lines ciossing in creok snow locations of scoss sections given on Plate XIII, lengitudinal section shows grade and thiekness of musk and gravel, and columnar se stions thow bed at points indieated. 


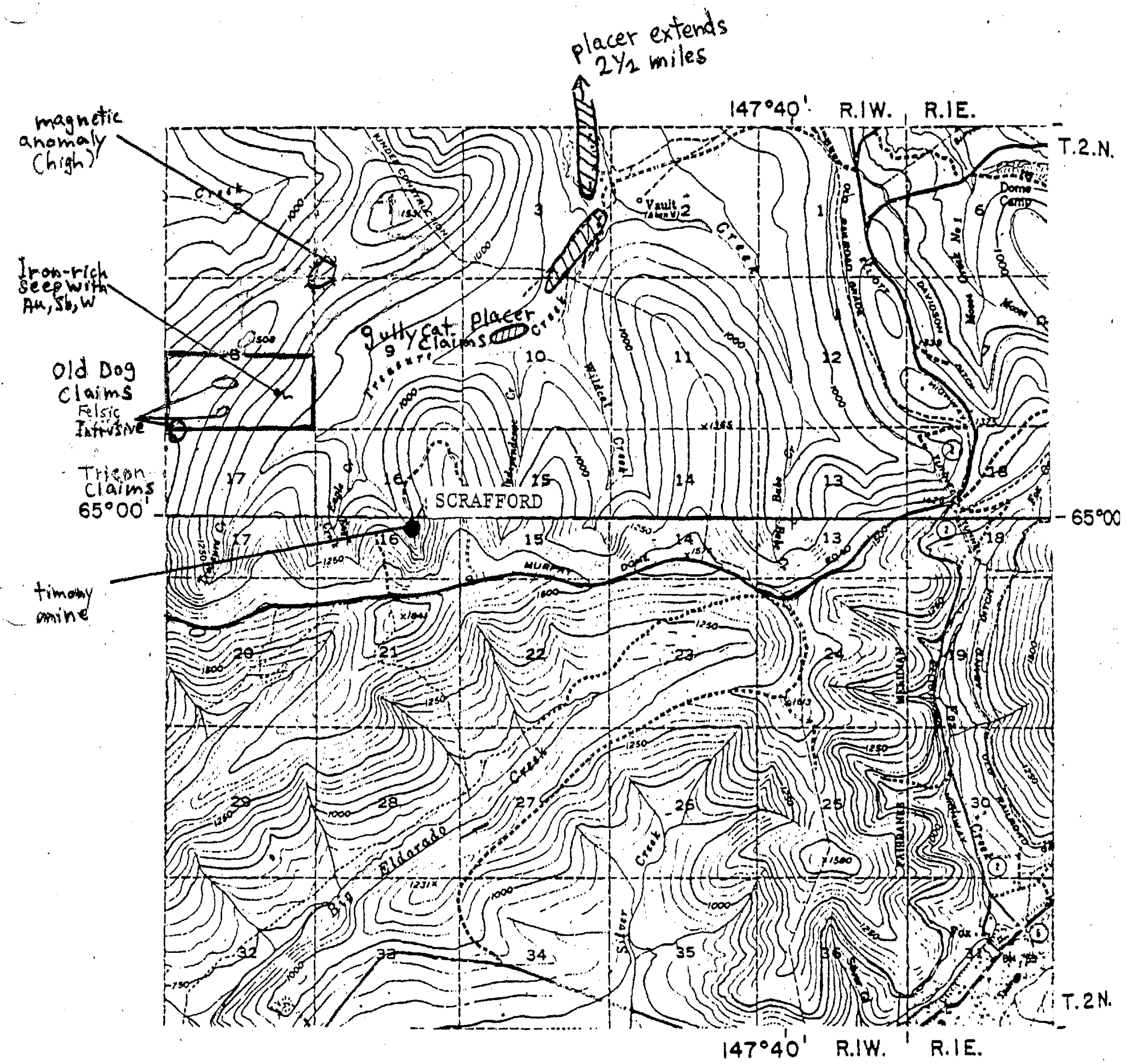

Base from U.S. Geological Survey Fairbanks D-2 (1954, revised 1975) and Livengood A-2 (1954) Quadrangles.

Scale $1 \mathrm{in.}=1$ mi 


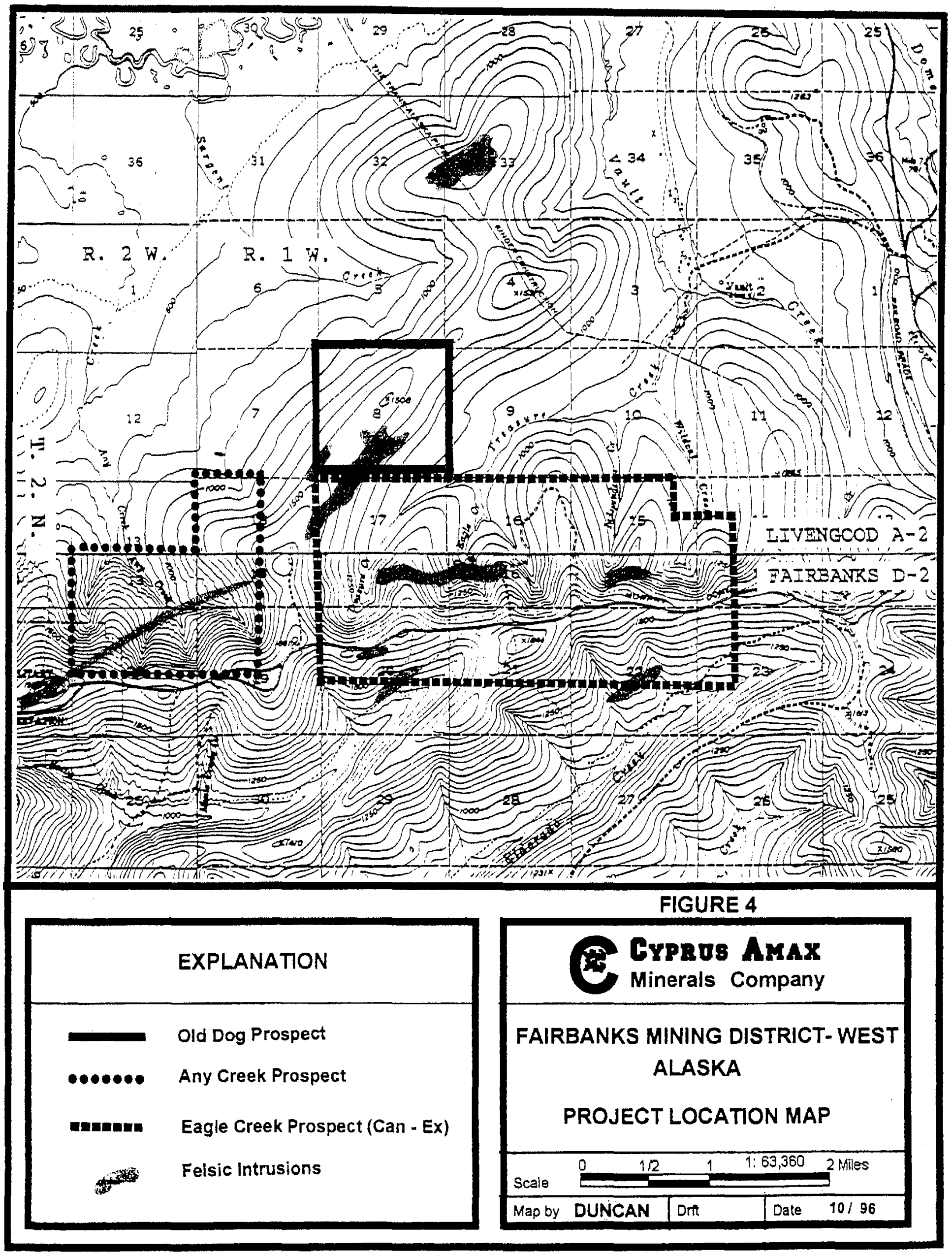




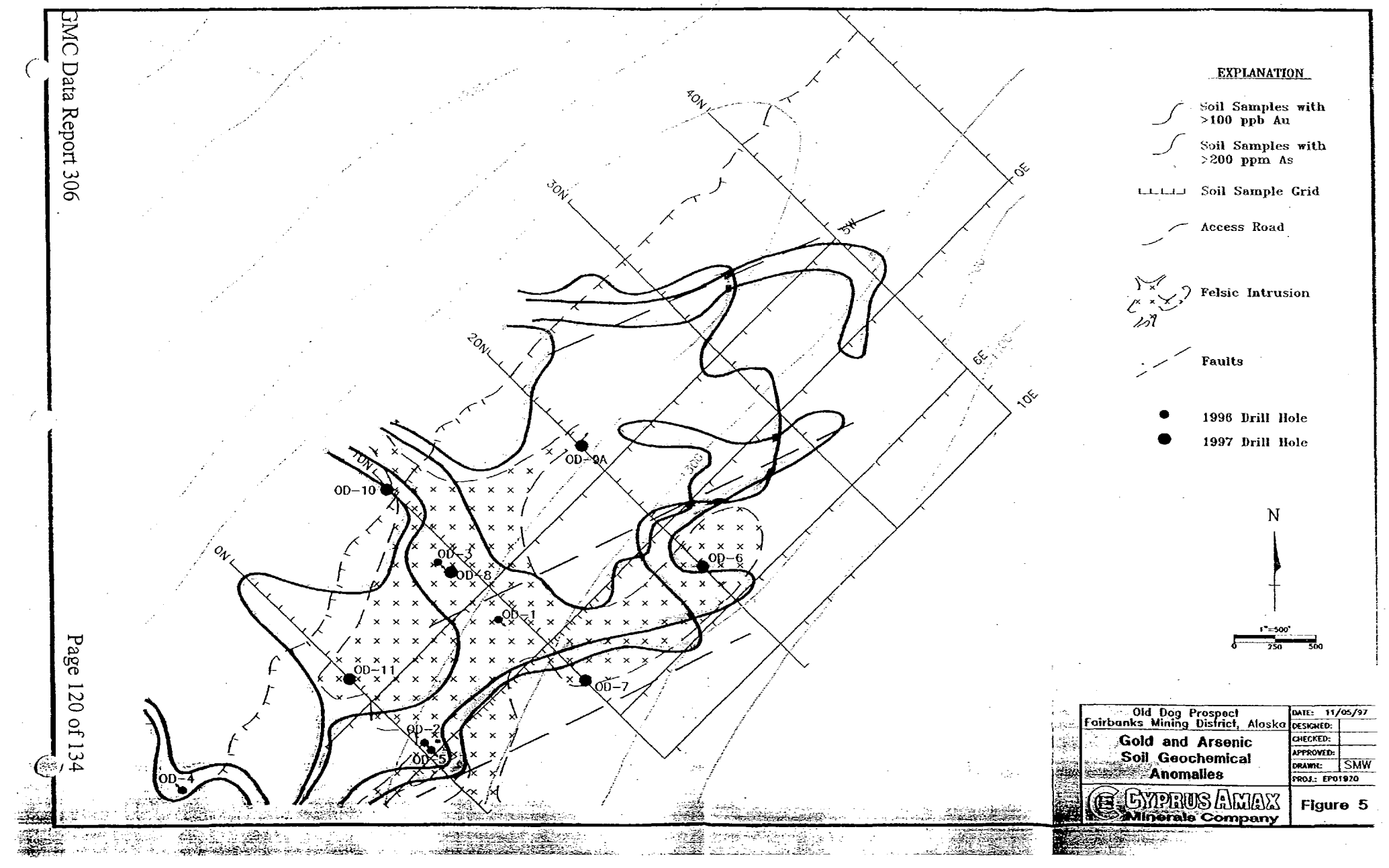



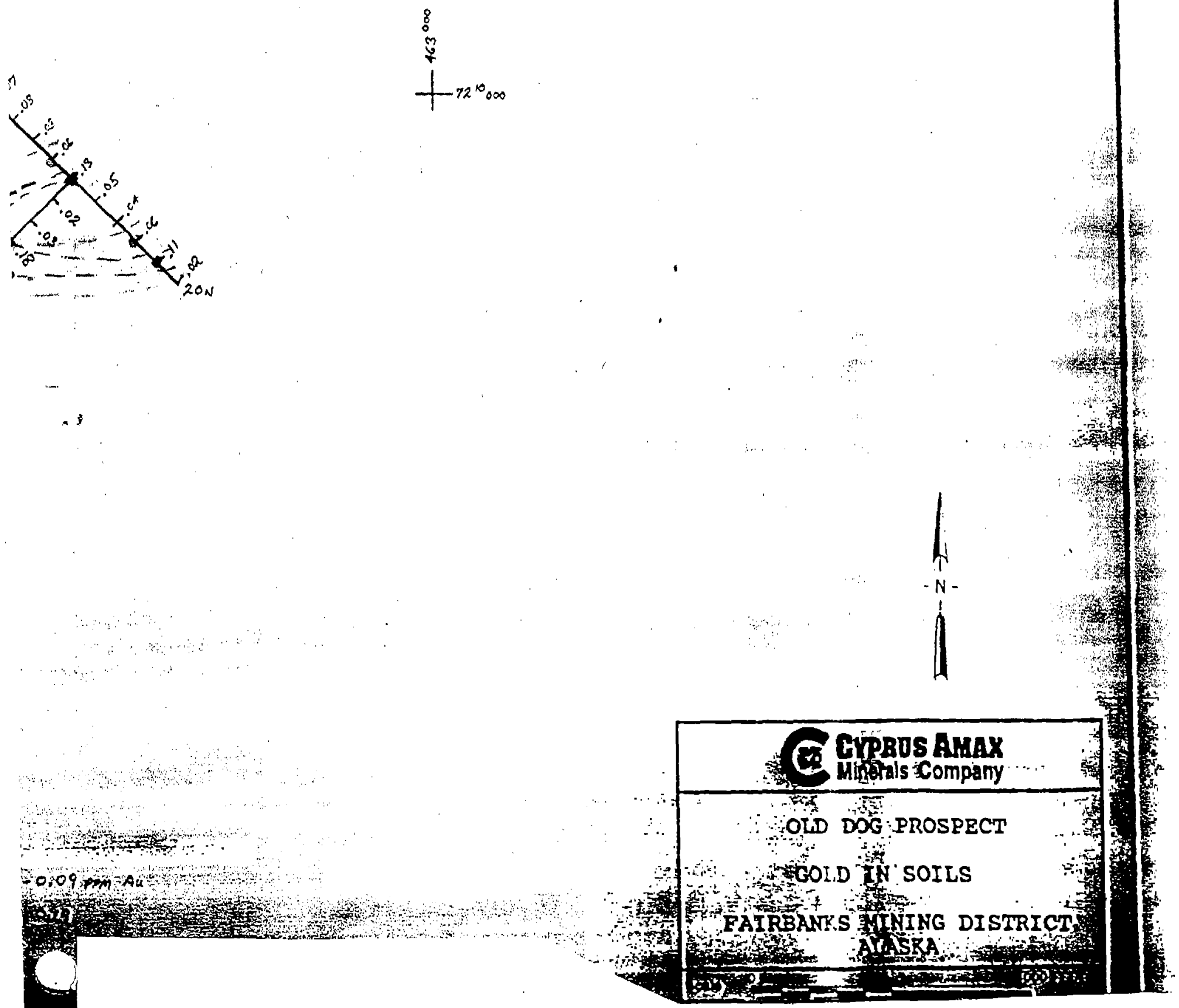

GMC Data Report 306 


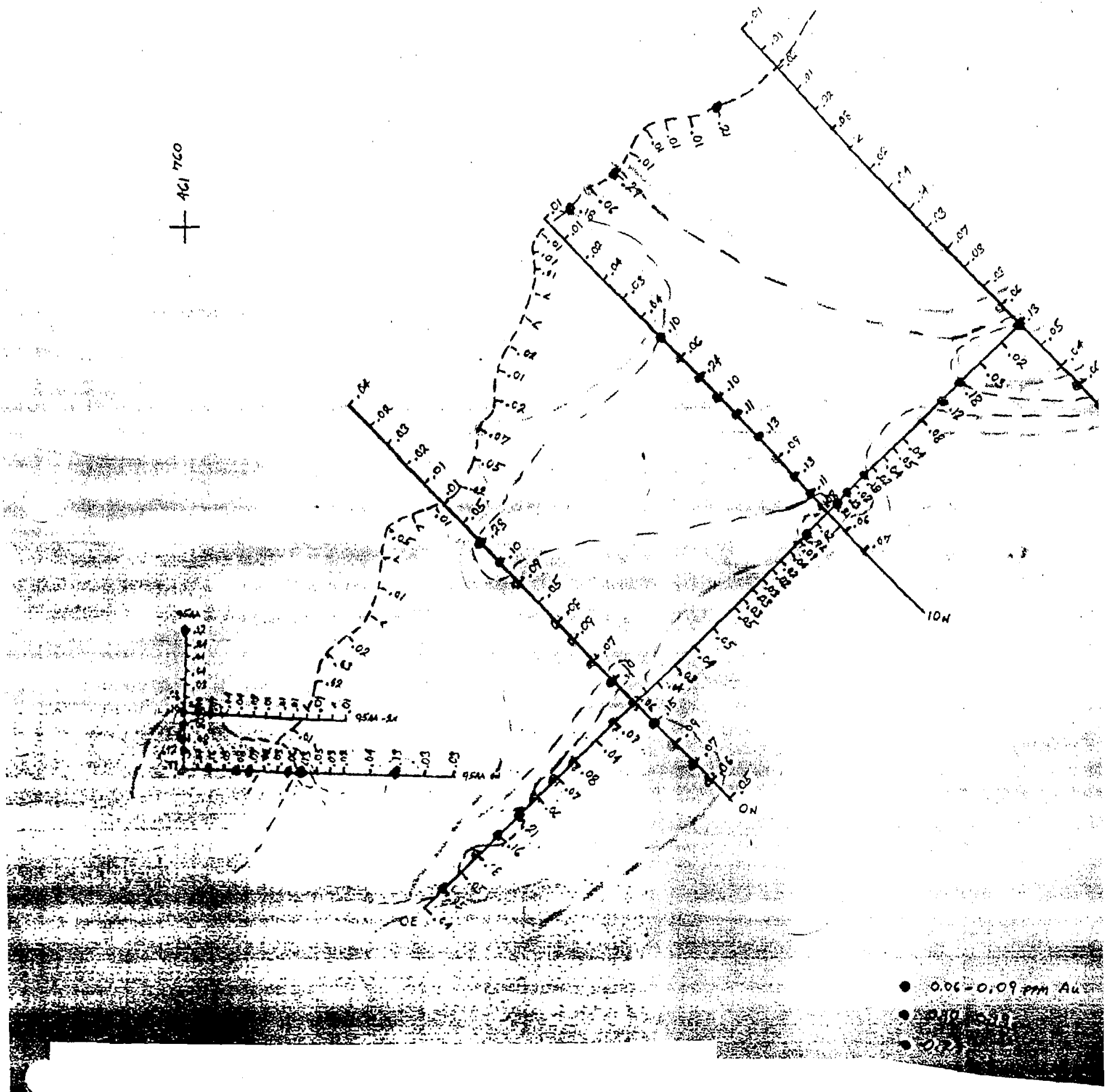



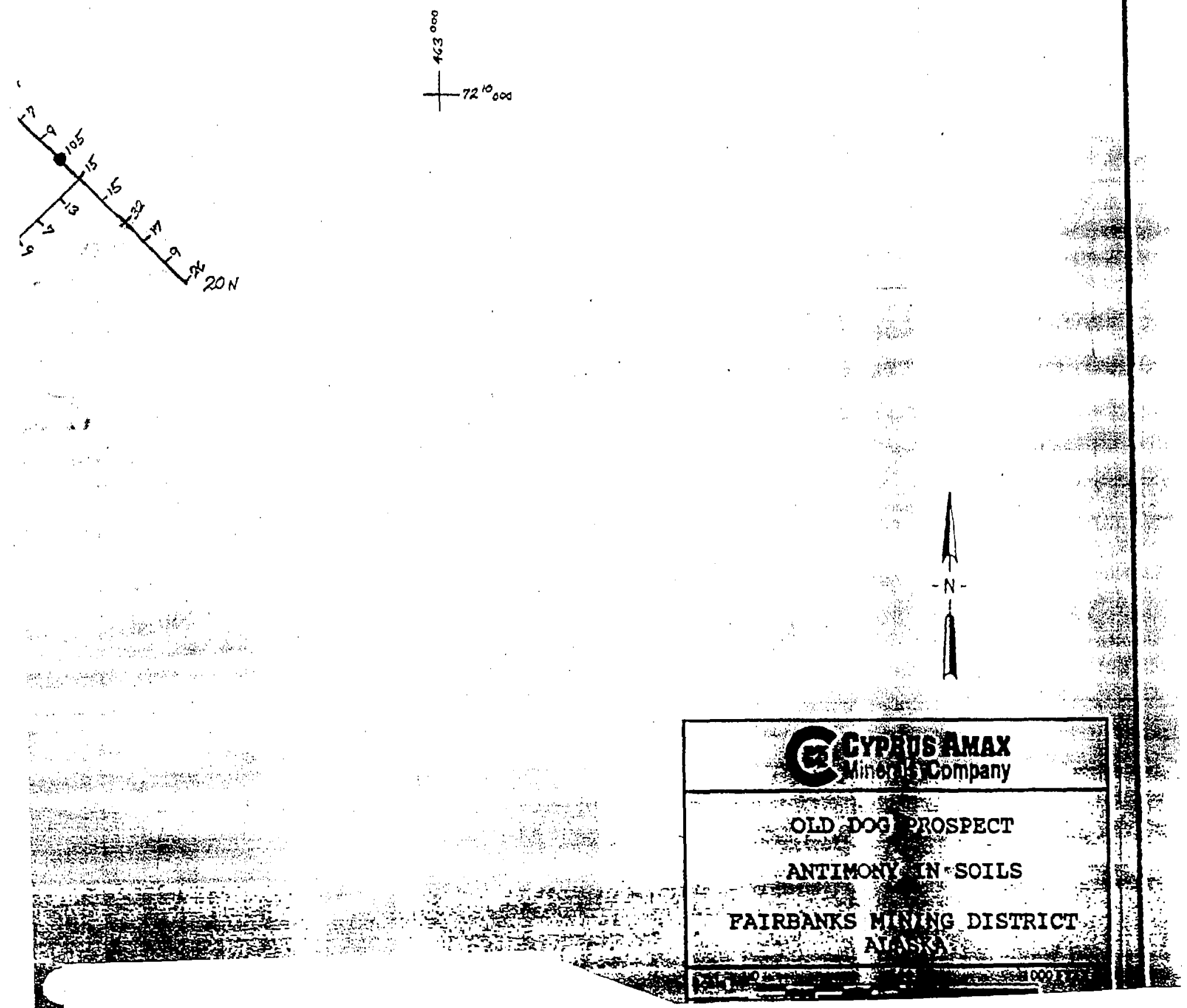

GMC Data Report 306 


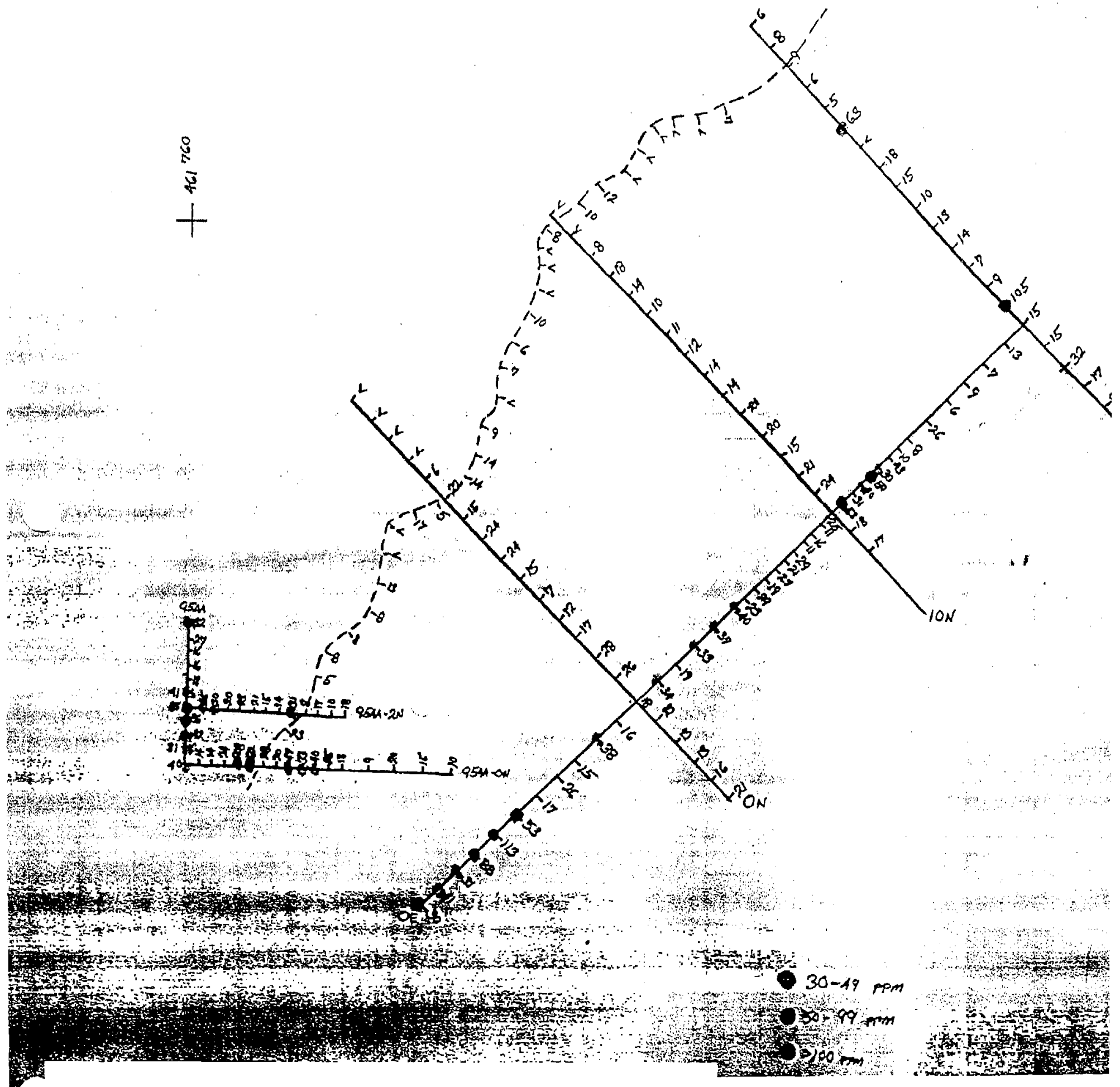




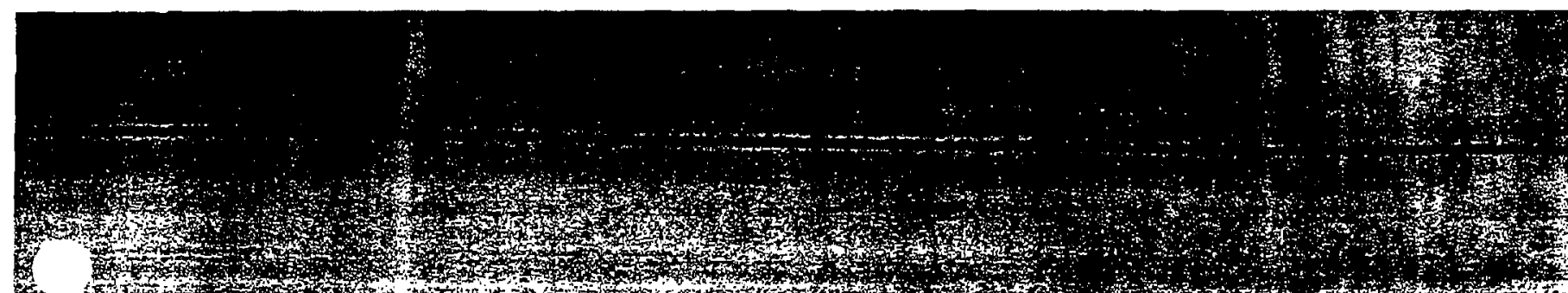

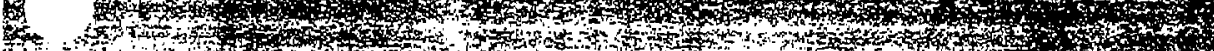

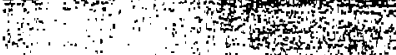

?

\section{$0,1+3$}

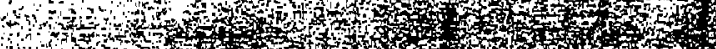

\%

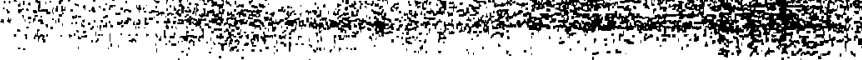

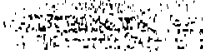

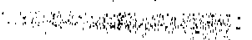

-
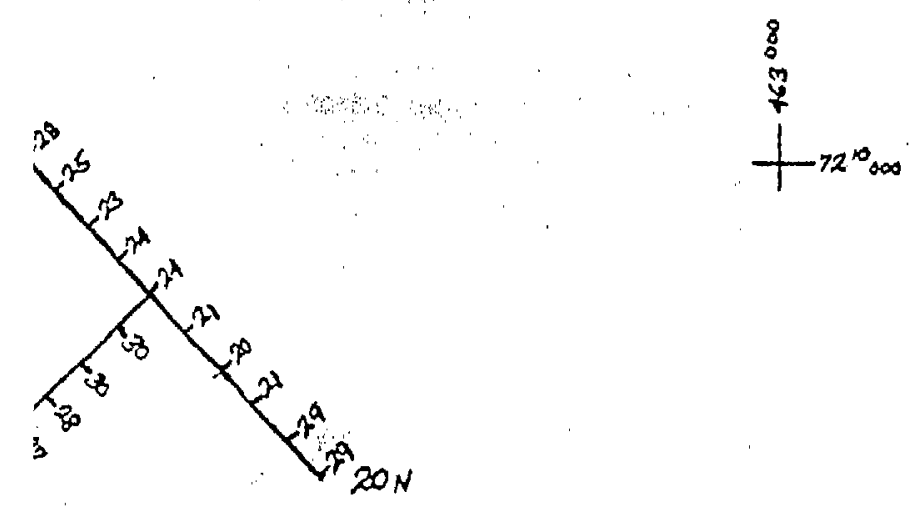

tot

thents
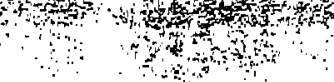

(n)

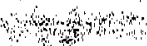

4 4 की

का

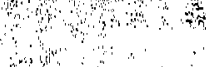

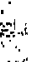


8

8
5
7
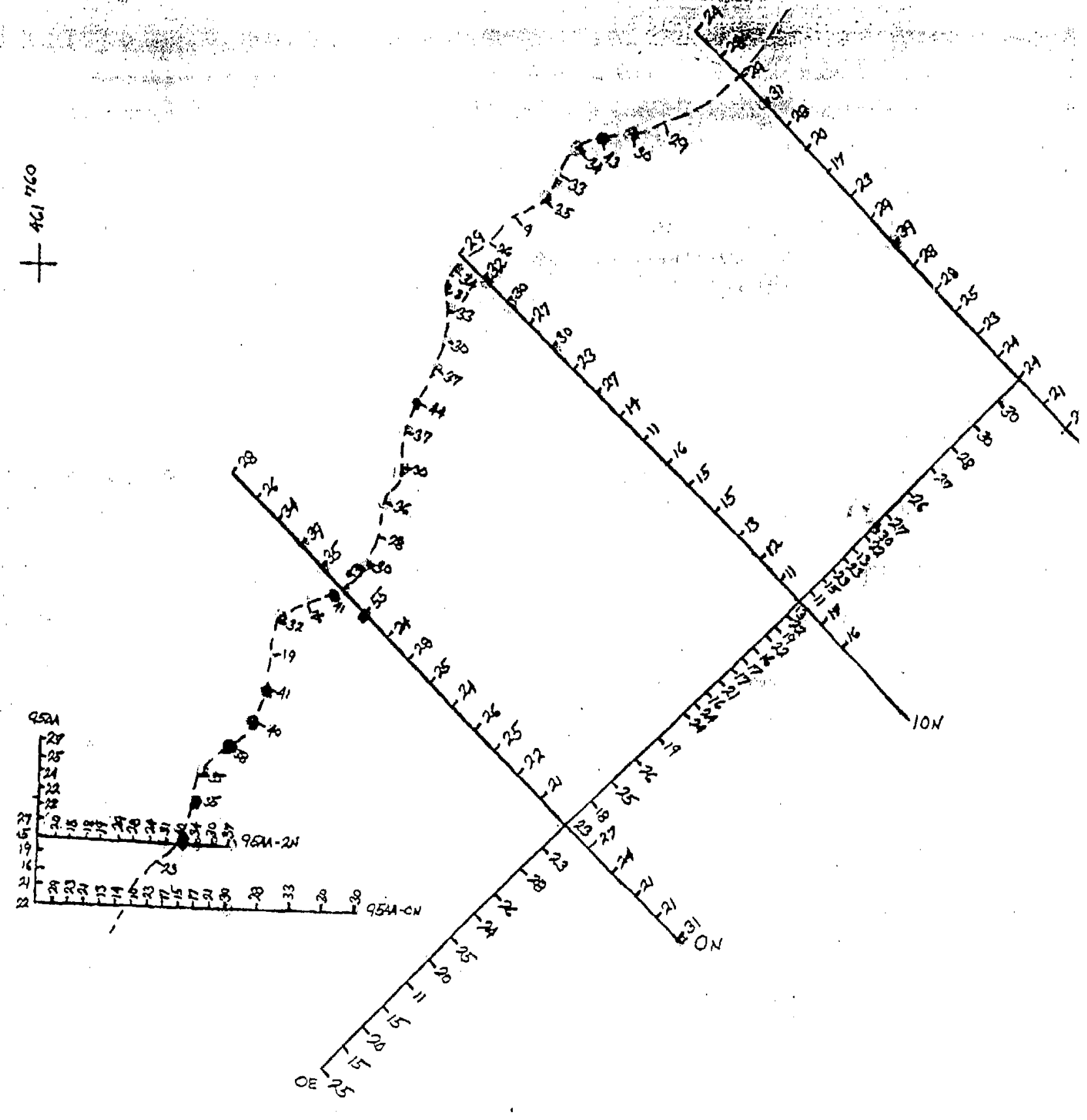

$\therefore \quad 30-39 \mathrm{pm}$

- $40.49 \mathrm{~mm}$

$1>50$ 

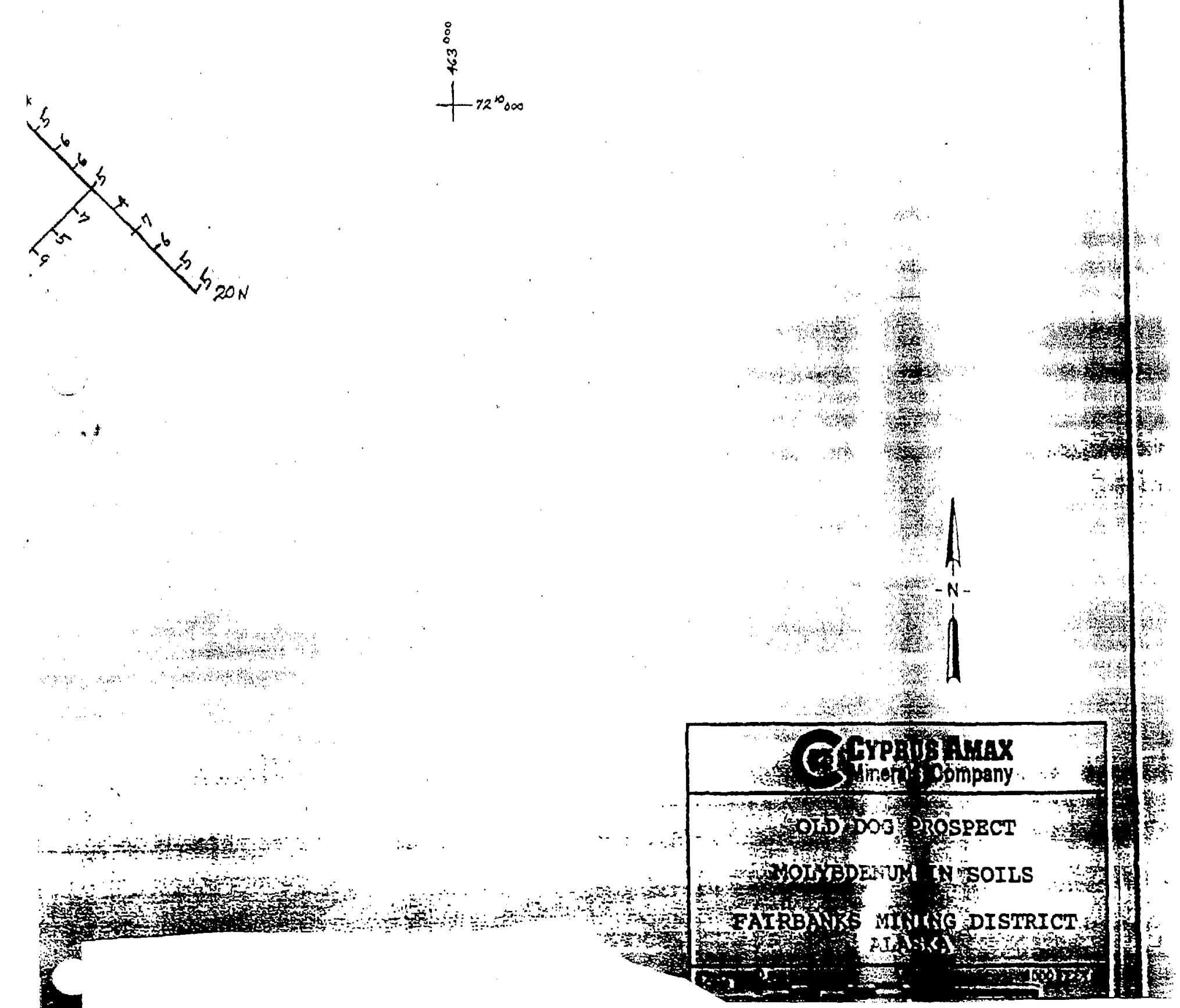

GMC Data Report 306

Page 127 of 134 


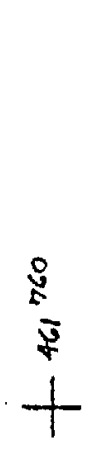

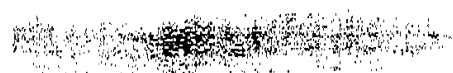

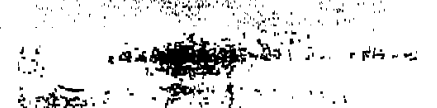

ite:

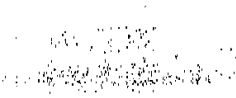

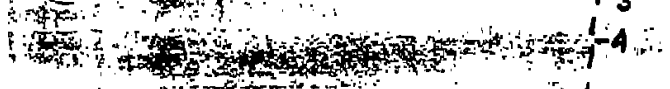

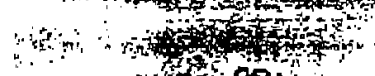

(n)

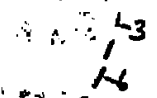

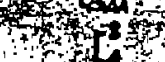

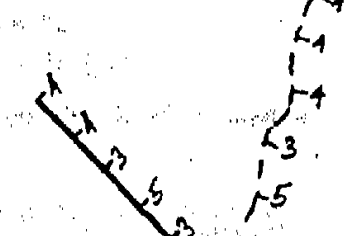

$<_{7} r_{5} T_{6} T_{5}^{2}$

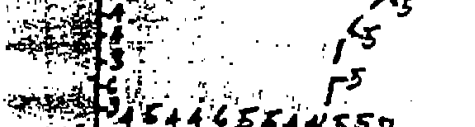

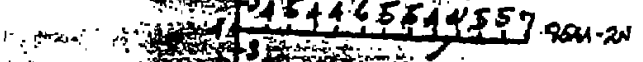

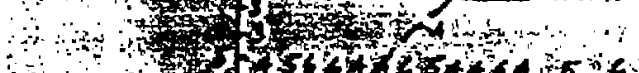

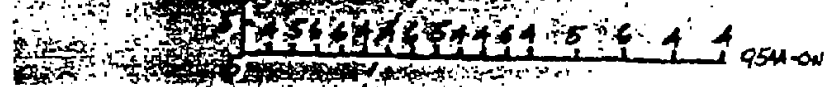

Whond

3 ard

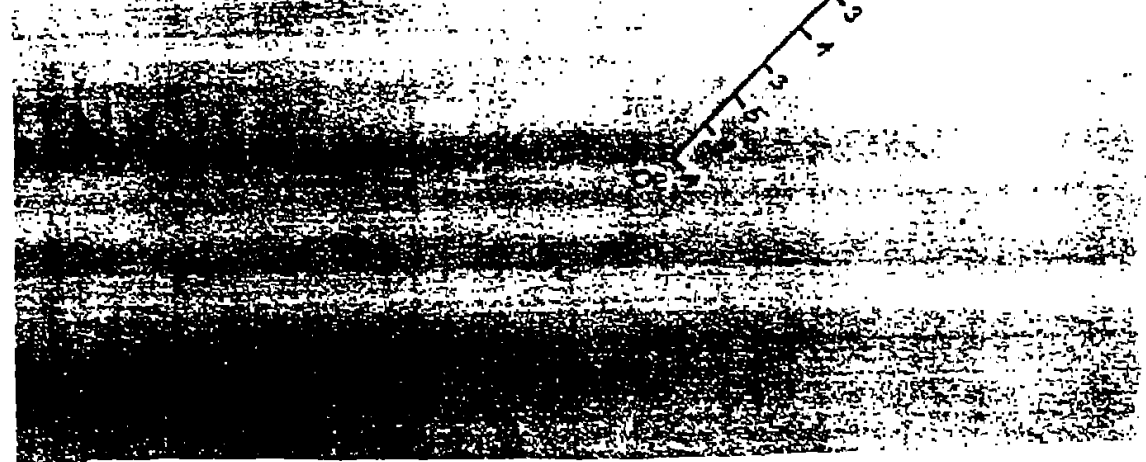



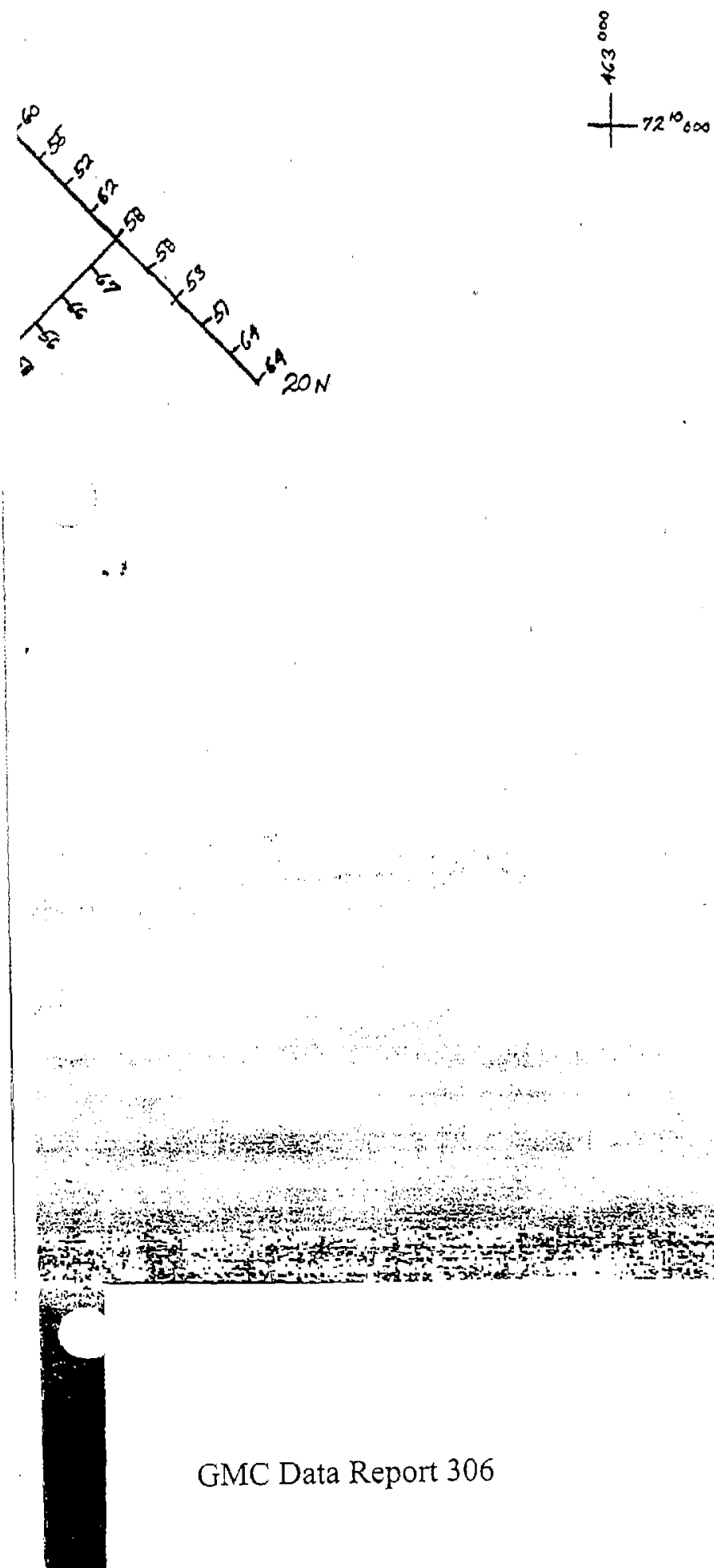

GMC Data Report 306

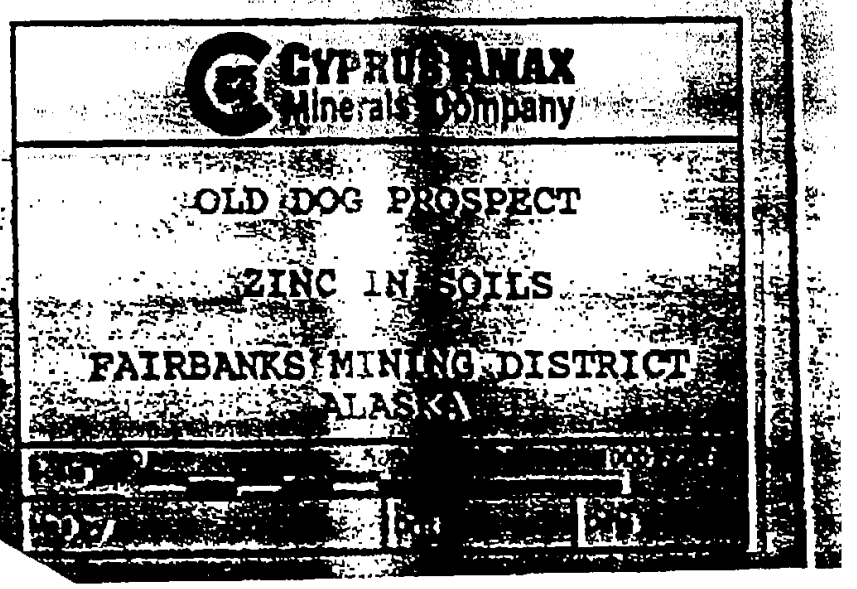

Page 129 of 134 


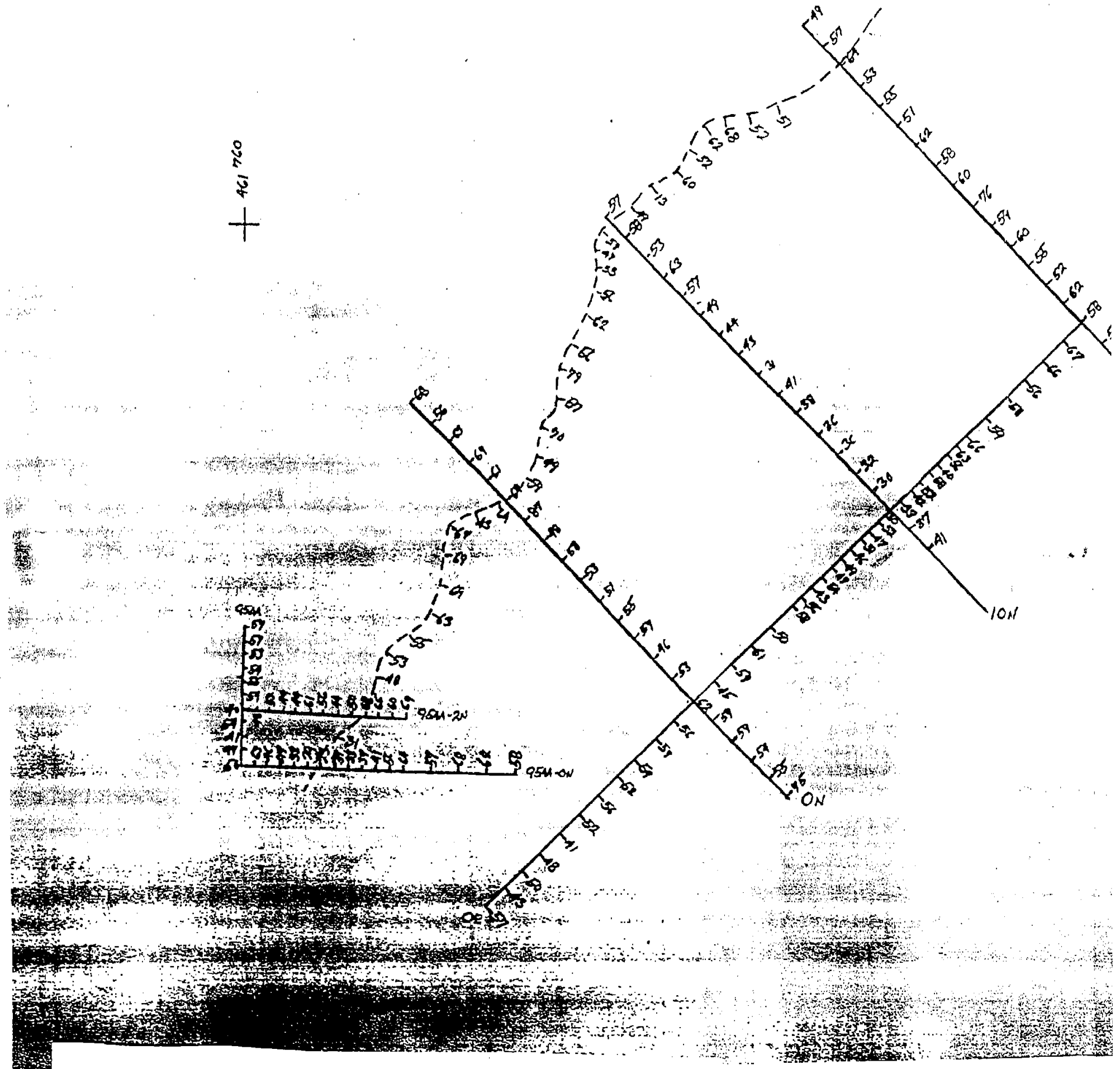




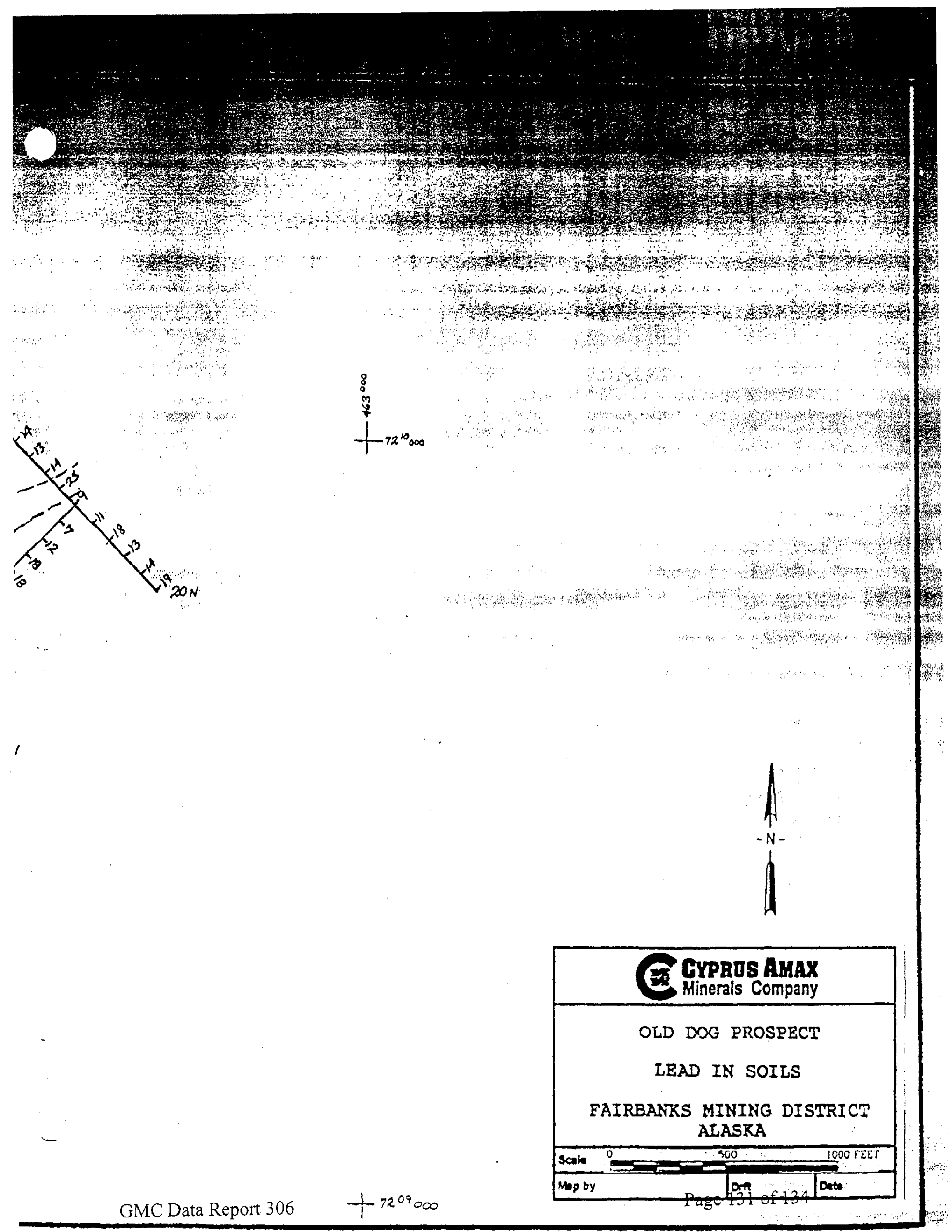




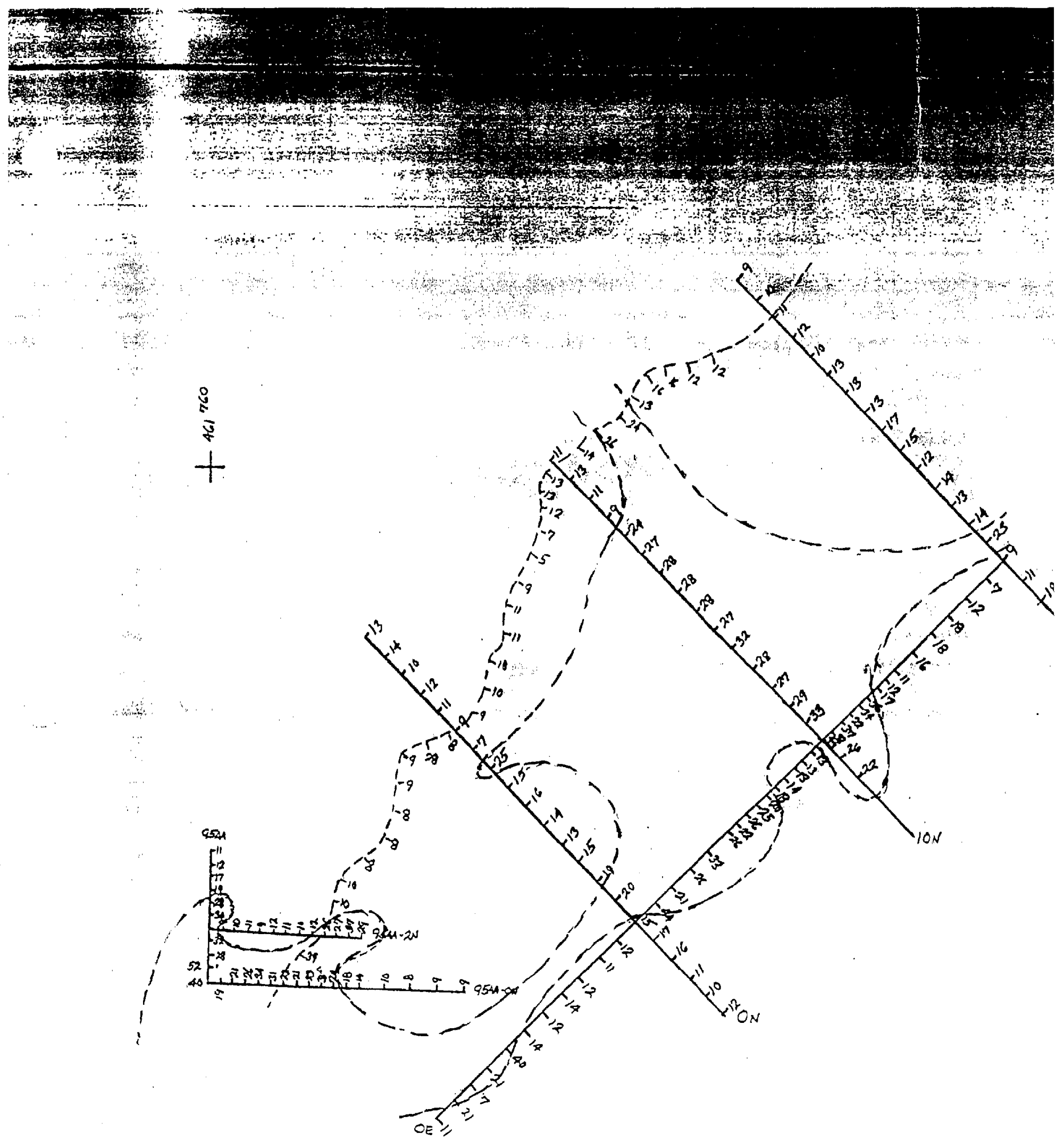



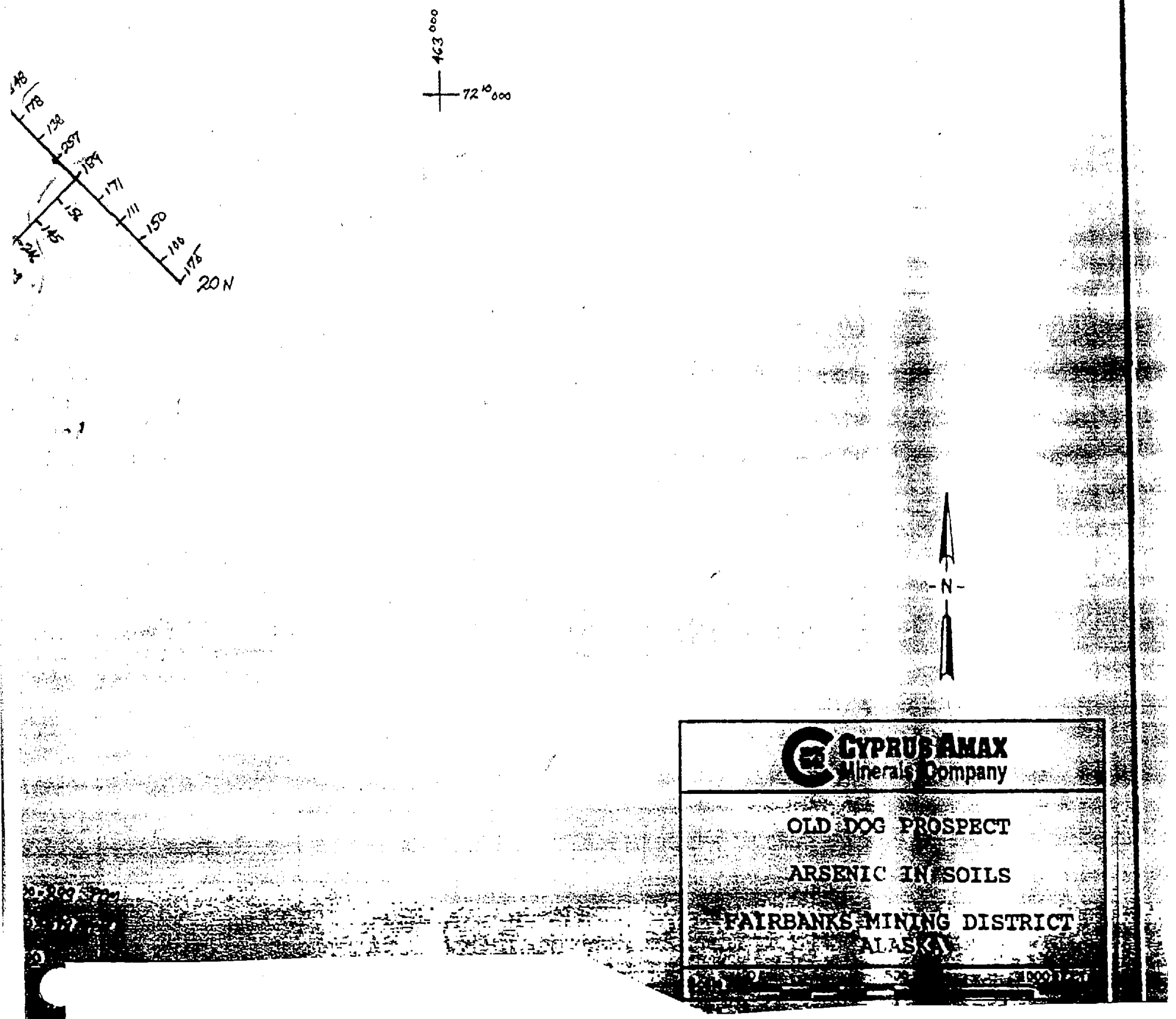


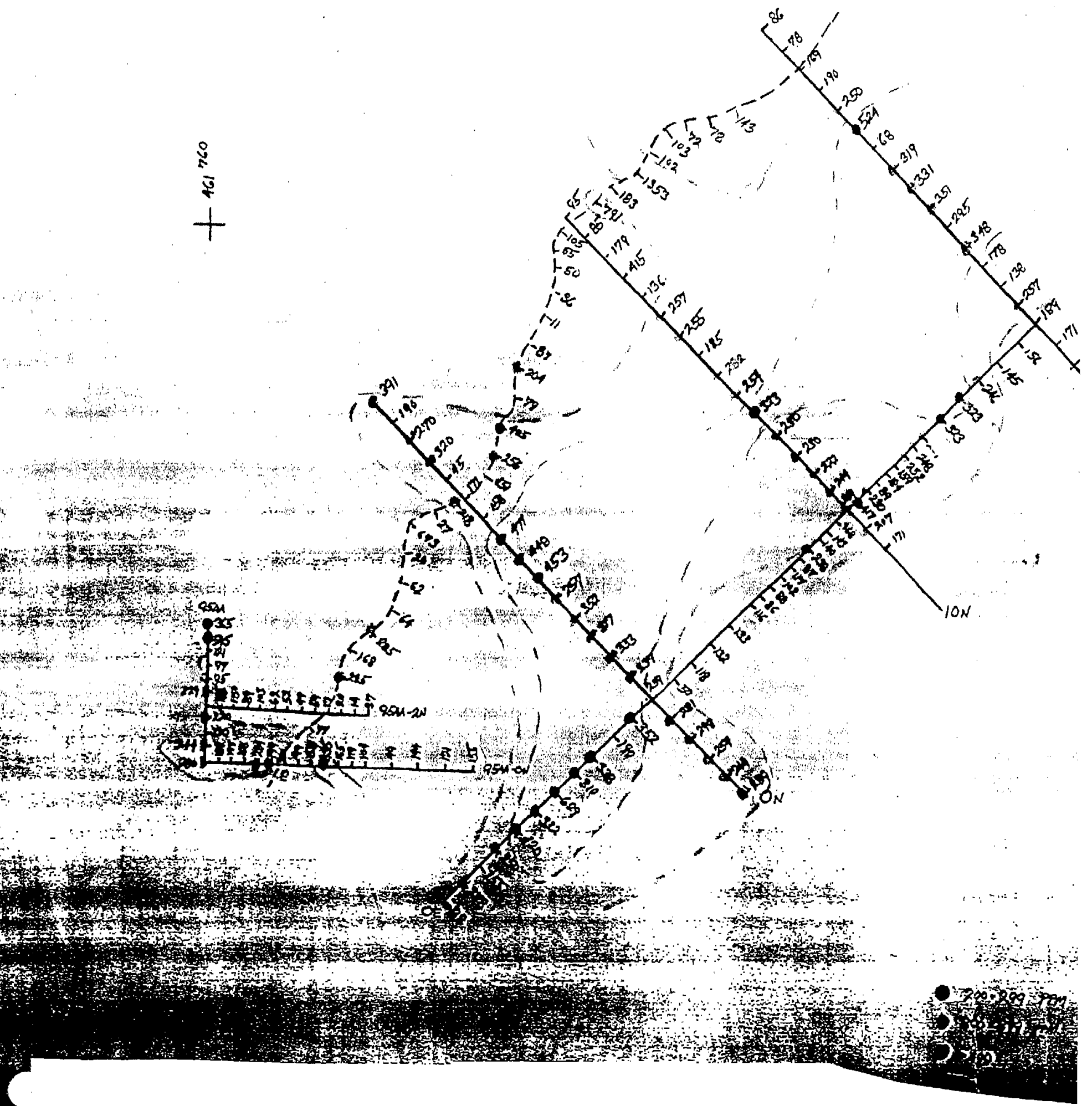

GMC Data Report 306 